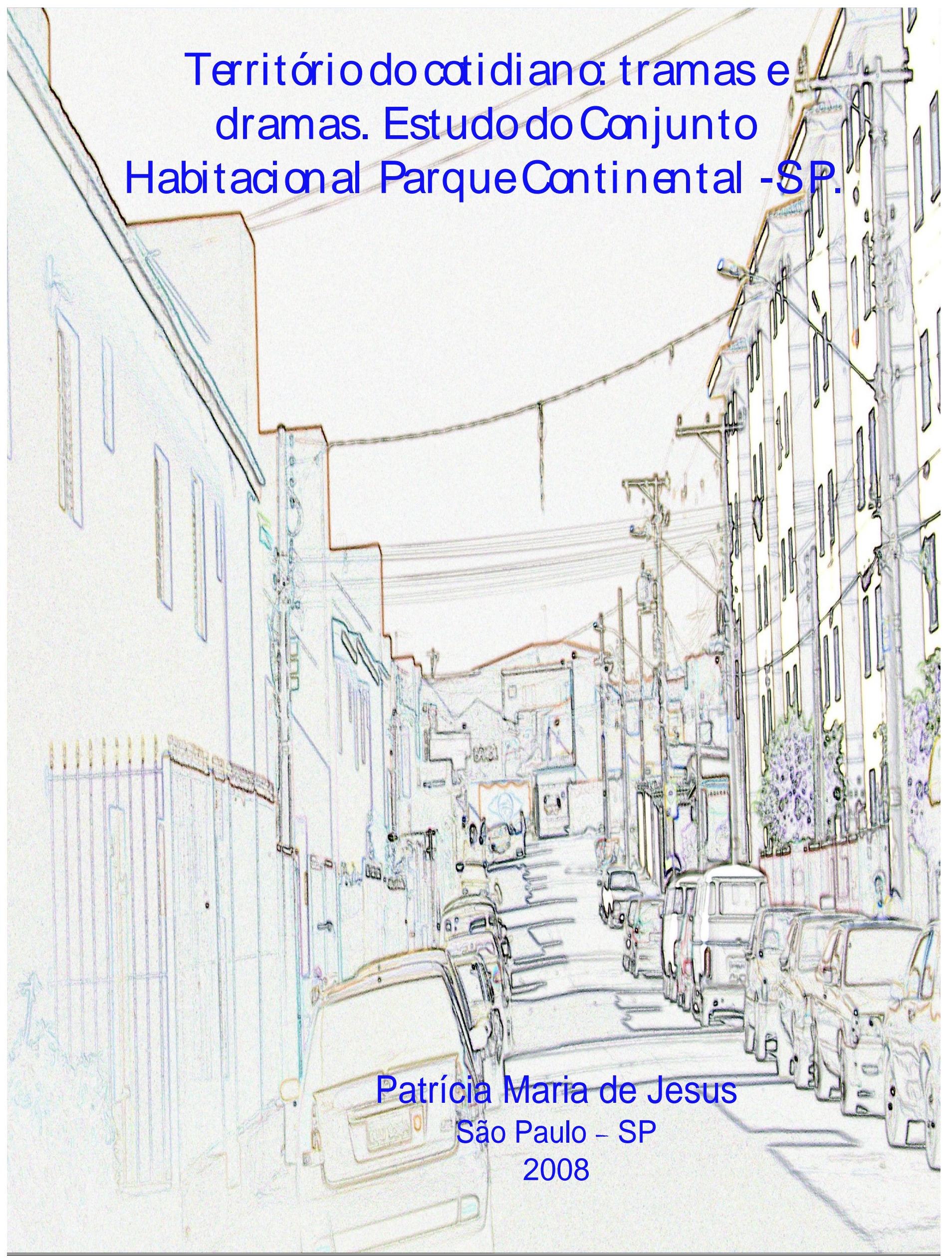




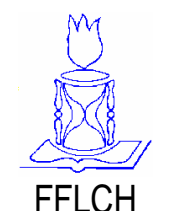

FFLCH
Universidade de São Paulo

Faculdade de Filosofia, Letras e Ciências Humanas.

Departamento de Geografia

Setor de Pós Graduação em Geografia Humana.

\title{
Território do cotidiano: tramas e dramas. Estudo do Conjunto Habitacional Parque Continental - SP.
}

\author{
Patrícia Maria de Jesus
}

São Paulo

2008 


\section{Patrícia Maria de Jesus}

\section{Território do cotidiano: tramas e dramas. Estudo do Conjunto Habitacional Parque Continental - SP.}

Orientadora: Prof ${ }^{\mathrm{a}} \mathrm{Pr}^{\mathrm{a}}$ Amália Inês G. Lemos.

Dissertação de Mestrado Apresentada ao Departamento de Geografia da Faculdade de Flosofia Letras e Ciências Humanas da Universidade de São Paulo como exigência para obtenção do grau de Mestre em Ciências na área de Geografia Humana.

São Paulo

2008. 


\begin{abstract}
À minha mãe, que mesmo em outra dimensão está sempre comigo, dedico este trabalho, mais uma, de muitas conquistas. Por nós, luto e busco forças, minhas únicas obstinações.
\end{abstract}




\section{Agradecimentos}

Por aceitar minhas escolhas e meus projetos muitas vezes sem entendêlos sem me questionar ou fazer qualquer objeção, agradeço a minha família, em especial a minha irmã Rosana por seu jeito muito peculiar de cuidar e proteger e meu irmão José Carlos pela nossa reconquista.

Por fazerem parte da dor e da delícia que é minha vida agradeço às minhas amigas Juliana Andrade, Simone, Sheilinha, Adriana. Àquelas que chegaram "depois" (mas que desejo e convido para ficarem mais tempo), agradeço à Carolina Fernucci, Tatiana Aleixo, Michele Debus, Fátima Oliveira, Andréa Angotti, Mônica Galindo. Os meninos: Saúde, Marcelo de Oliveira, Billy Malachias, Rafael Roxo, Clóves. A todos vocês meus francos e honestos agradecimentos por tolerarem com tamanha admiração e paciência minha inquietude e intranqüilidade e por me motivarem com tanto afinco.

Por acreditar que esse trabalho seria possível da maneira como ele foi concebido agradeço a Amália Inês, professora orientadora.

À Paula pela revisão cuidadosa do texto original.

Aos moradores do Conjunto Habitacional Parque Continental, todos, sem exceção que contribuíram direta e indiretamente para a realização desse trabalho.

À equipe da HABI (Superintendência da Habitação Popular) da SEHAB (Secretaria da Habitação e Desenvolvimento Urbano) da Prefeitura do Município de São Paulo, em especial à Violeta Kubrusly, Márcia e Suzy (HABI I) e Nancy (HABI II) pela cessão de material e interesse pela pesquisa.

Um agradecimento muito especial a Valdemar Nogueira, meu namorado com N "grande", pela possibilidade de amar. 


\section{O lutador}

Lutar com palavras é a luta mais vã.

Entanto lutamos mal rompe a manhã.

São muitas, eu pouco.

Carlos Drummond de Andrade. 


\section{Resumo:}

Trata-se do estudo da vida cotidiana de um conjunto habitacional de interesse social na cidade de São Paulo, e da constituição desse fragmento de espaço da metrópole enquanto um "território cotidiano". Interessou-nos averiguar a apropriação afetiva dos moradores da área em questão com o espaço efetivo concebido pelo poder público municipal. A orientação de nossa investigação foi construída por meio de dois níveis analíticos: um primeiro que diz respeito ao cotidiano como modo de vida específico da contemporaneidade capitalista e um segundo que se refere à análise da vida cotidiana regida por esse modo de vida. Para isso, analisamos as políticas municipais de habitação implementadas no período de 1989 à 2000 que coincidiu com três administrações municipais: Luiza Erundina, à época filiada ao PT(1989 - 1992), Paulo Maluf, à época filiado ao PPB (1993-1996) e Celso Pitta, à época filiado também ao PPB (1997-2000). O referencial teórico apoiou-se fundamentalmente em Henri Lefebvre e Agnes Heller.

Palavras-Chaves: vida cotidiana, cotidiano, políticas municipais de habitação.

\section{Le Résumé:}

Ce travail s'agit sur l'étude de la vie quotidienne de un groupe d'habitation d'intérêt social dans la ville de São Paulo, et la constitution de ce fragment de l'espace de la métropole pendant qu'un «territoire du quotidien ». Nous avons intéressé s'enquérir l'appropriation affective des résidents de l'aire étudiée avec l'espace effectif conçu pour le pouvoir publique municipal. L'orientation de notre investigation a été établie pour moyen de deux niveaux d'observation : un premier que s'agit sur le quotidien comme façon de vie spécifique de la contemporanéité capitaliste et un deuxième que s'agit à l'observation de la vie quotidienne soumise pour cette moyenne de vie. Dû à cette chose, nous avons analysé les politiques municipaux d'habitation implémentées dans le période de 1989 jusque 2000 que a coïncidé avec trois administrations municipaux : Luiza Erundina, dans l'époque liée au PT (19891992), Paulo Maluf, dans l'époque lié au PPB (1993-1996) et Celso Pitta, dans l'époque lié aussi au PPB (1997 - 2000). Le référentiel théorique a été basé fondamentalement sur Henri Lefebvre et Agnes Heller.

Les mots-clés : la vie quotidienne, le quotidien, logements sociaux 


\section{Introdução}

Porque centrar atenção no estudo do cotidiano?

\section{Território do cotidiano: Constituição a partir da política de habitação de Luiza Erundina de Souza}

1.1 Sobre a escolha do recorte territorial e a periodização...........................................15

1.2 Jaguaré Do distrito industrial ao loteamento Parque Continental...........................16

1.3 No Parque Continental, o Mutirão Estrela Guia................................................20

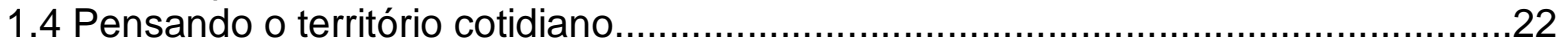

1.5 Políticas Habitacionais em São Paulo: Antecedentes...........................................28

1.6 A política de provisão de habitação na administração Luiza Erundina......................31

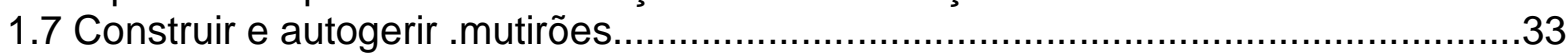

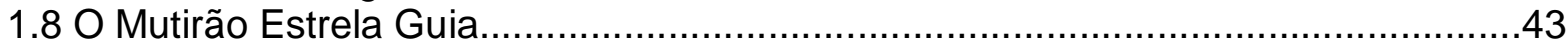

1.9 Autoconstrutores: Entre ideais, conquistas e frustrações........................................45

\section{Território do cotidiano: Constituição a partir da política de} habitação de Paulo Maluf e Celso Pitta.

2.1 Prover habitação por acaso?

2.2 O desmonte da política anterior.

2.3 A política de provisão de habitação na administração de Paulo Maluf e Celso Pitta 63

2.4 O PROVER (Programa de Verticalização de Favelas)........................................... 65

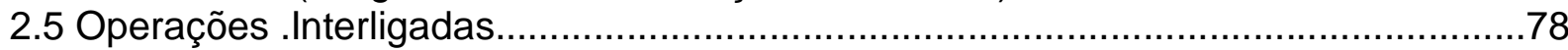

2.6 A implantação do Conjunto Habitacional Parque Continental................................. 81

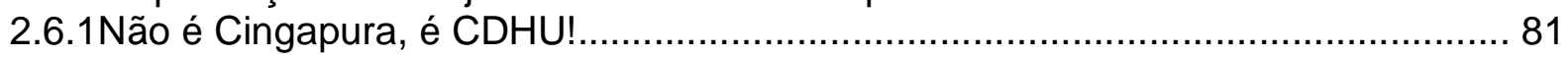

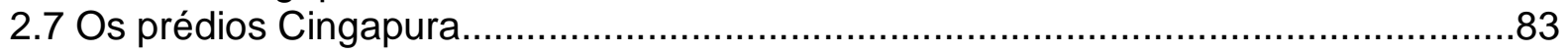

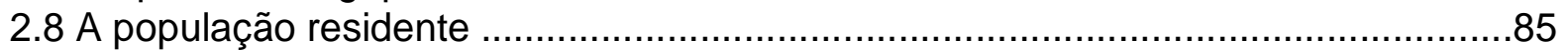

$2.9 \mathrm{Na}$ aparente homogeneidade uma interlocução heterogênea.................................89

2.10Moradores Entre o inacreditável e a incredulidade............................................... 91

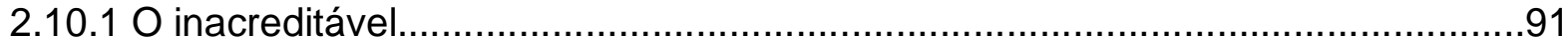

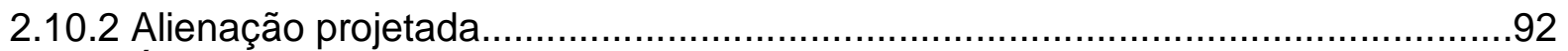

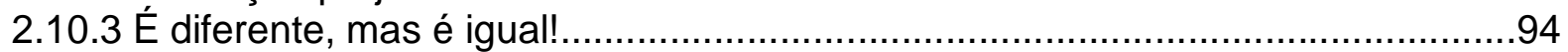

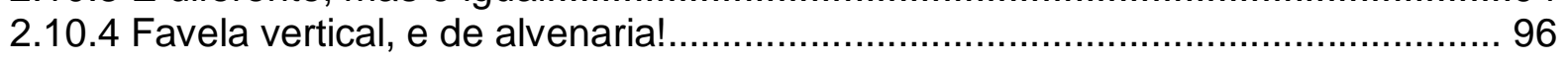

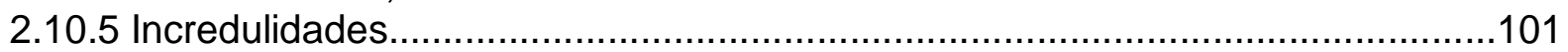

\section{Práticas cotidianas: tramas e dramas na vida cotidiana.}

3.1 Para analisar a vida cotidiana.......................................................................

3.2 Cotidiano X Modernidade: a relação entre ambos.............................................................107

3.3 Henri Lefebvre e a vida cotidiana no mundo moderno.........................................111

3.4 Habitar X habitat: vivendo no Conjunto...................................................................129

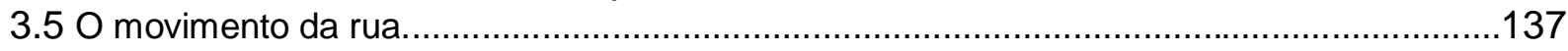

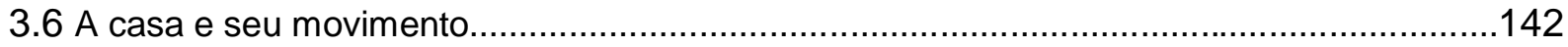

3.7 Espaço cotidiano o lazer praticado no Conjunto.....................................................148

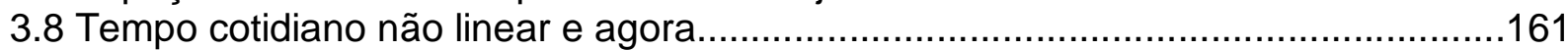

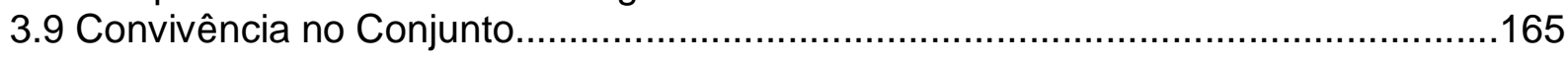


Práticas cotidianas: tramas e dramas na vida cotidiana.

3.1 Para analisar a vida cotidiana.......................................................................106

3.2 Cotidiano X Modernidade: a relação entre ambos........................................................107

3.3 Henri Lefebvre e a vida cotidiana no mundo moderno.........................................111

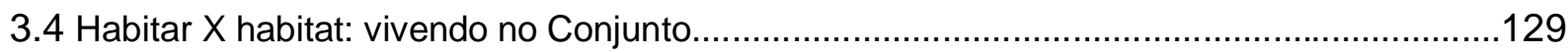

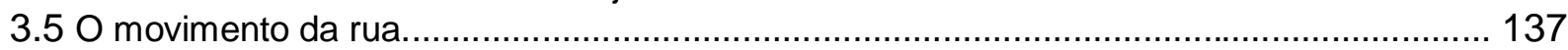

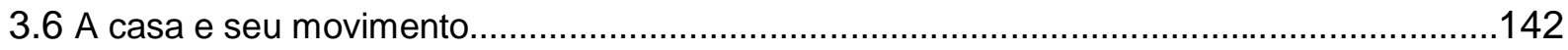

3.7 Espaço cotidiano o lazer praticado no Conjunto.....................................................148

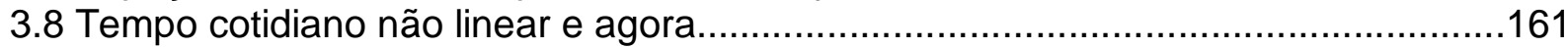

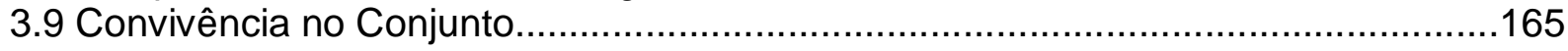

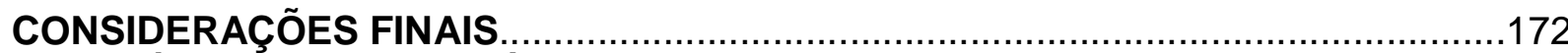

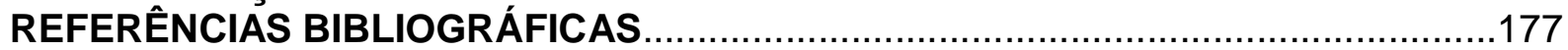

ANEXOS 


\section{Introdução}

Porque centrar atenção no estudo do cotidiano?

Por ocasião do centenário de morte de Marx em 1983, Henri Lefebvre justificou o surgimento do conceito de vida cotidiana argumentando que os estudos acerca do trabalho, da produção e dos locais de produção necessitavam de uma complementação. Interessava a ele não só a vida do trabalhador na fábrica, mas o que se passava fora desses locais. Dizia ele não ser esse argumento excludente do processo produtivo, mas complementador do mesmo. Necessitaria levar em conta a maneira de realizar lazer, a vida privada e familiar do trabalhador. ${ }^{1}$

Antes de entrar em contato com o texto do qual nos referimos, nossa justificativa para estudar o cotidiano era de que, para além da constatação das dinâmicas de segregação socioespacial ${ }^{2}$ presentes nas áreas periféricas das cidades contemporâneas, que crescem a cada dia e, que por tal motivo são merecedoras de atenção, era importante conhecer como vivem os habitantes desses territórios, ou seja, quais as interações entre esse espaço e seus agentes sociais, expressa através da produção (material e simbólica) da vida, das relações entre as pessoas, dos lugares que freqüentam, dos trabalhos que exercem, do modo de se comportar e de entender o mundo? Já partíamos do pressuposto de entender o cotidiano fora dos locais de trabalho, mas por outro caminho de reflexão. Por esse ou aquele viés, no entanto, reconhecemos a necessidade do estudo proposto.

Se Marx deteve seu olhar sobre o operário das fábricas, hoje, no entanto, há que se considerar que não só extinguem-se os trabalhos fabris, como também são suprimidos os empregos... Diminuem-se as jornadas de trabalho, os tamanhos das habitações, os tempos reservados aos programas familiares e as próprias famílias. Toda a vida é alterada em virtude das determinações impostas pelo desenvolvimento do modo de produção capitalista.

Num mundo onde nada mais se define pelos tempos cíclicos da natureza, mas sim pelo tempo do mercado, da mercadoria, da tecnologia; o cotidiano encontra subsídio para ser analisado à luz do desenvolvimento das forças produtivas, e constitui nosso propósito incitar também o debate sobre a inter-relação das dimensões da vida cotidiana.

\footnotetext{
1 AJZENBERG, Armand. As classes sociais e suas formas modernas de luta. In: Revista GEOUSP - Espaço Tempo, São Paulo, nำ17. 2005. p 09-19.

2 Nossa preocupação em pesquisa anterior (JESUS, 2005), e que em muito contribuiu para a delimitação do problema de pesquisa nesse trabalho.
} 
Convém chamar atenção para a contradição do capitalismo a muito amplamente debatida pelos estudiosos do assunto: esse modo de produção ao mesmo tempo em que integra e desenvolve certos espaços, desintegra e deteriora outros. O cotidiano dos espaços "desintegrados", ou dos espaços incluídos precariamente nesse sistema de produção, é o que interessa para nosso estudo ${ }^{3}$. Nele as contradições do sistema são visíveis, ainda que indevidamente analisadas e contribuir para essa discussão é premente.

Investigamos o cotidiano e a expressão de sua dimensão espacial ao longo da pesquisa. Concomitantemente, inferimos como essa categoria de análise vem se construindo na Geografia, pois como indagou Lefebvre "Por que uma ciência em particular (...) não traria sua contribuição para o estudo da vida cotidiana?' (1991 p.28). Em relação ao estatuto das ciências parcelares, uma dúvida acomete o autor: "Nunca se soube se elas delimitam seus objetos e domínios numa totalidade daí em diante irredutível às suas particularidades, ou se elas lançam luzes particulares sobre uma realidade global". (idem, p.27). Para Silva (1995), "a Geografia é uma ideologia do cotidiano (...) e daí a importância do espaço da vida, de tal modo que se possa dizer que viver, no presente, é continuamente estar a abrir espaço, desde o da habitação até o da vida afetiva"'. Ou seja, o modo de construir habitações e de habitar implica substancialmente nas relações afetivas entre as pessoas.

Afirmamos que a Geografia contribui para esse estudo, e nos debruçaremos sobre tal contribuição ao longo desse trabalho. Por hora, faremos um arrolamento de aspectos relevantes no estudo do cotidiano, como maneira de apreender a realidade da vida contemporânea tão cheia de contradições como já assinalamos.

No nível da reflexão teórica, o cotidiano como veremos adiante é menos um conceito e muito mais uma esfera, uma dimensão, uma espaço-temporalidade da vida contemporânea. É nosso intuito encontrar coerência no aparentemente "sem sentido", pois, o cotidiano é ainda visto por muitos autores como senso comum e por isso mesmo aquém dos postulados da ciência.

Para introduzir o debate nos apoiamos em Petersen (1995, p.30). Para essa autora apesar da vasta produção bibliográfica sobre a vida cotidiana, principalmente no campo da história, sociologia e antropologia, há um ponto frágil em toda ela: pouca preocupação teorizante, e a inexistência de uma definição mais consistente desse objeto. Para ela, o cotidiano como conceito tem um significado flutuante e poucos autores tratam de ir além do simples conceito, propondo uma reflexão teórica mais abrangente sobre esse âmbito, e o cotidiano se encontra na

\footnotetext{
3 HAESBAERT, Rogério designa tais espaços como aglomerados de exclusão. O mito da desterritorialização: do
} fim dos territórios à multiterritorialidade. Rio de Janeiro: Bertrand Brasil, 2004. (cap 7). 
difícil intersecção dessas formas de conhecimento que chamamos "ciência" e "conhecimento comum".

Para a referida autora:

Em relação à escassa reflexão teórica dos estudos sobre a vida cotidiana, geralmente descritivos ou onde "cotidiano" é um pano de fundo de cores pastéis, diante do qual uma trama se desenvolve, pode-se argumentar que tais estudos procedem de uma matriz crítica da epistemologia científica e que, portanto, não se poderia esperar encontrar neles o modelo dessa epistemologia, onde a teoria ocupa um papel central.Talvez pelo próprio conteúdo da vida cotidiana, seu estudo tem sido ao mesmo tempo objeto e desencadeante (ainda que não exclusivo) de uma reflexão epistemológica com pressupostos diferentes daquela da ciência, ou seja, desconfiada das construções teóricas de corte racional, mais preocupada em acompanhar empaticamente a sociedade que submetêla à lógica redutora e totalizante dos conceitos, que valoriza o sentido comum no processo cognitivo e que trata de introduzir na análise do social as dimensões do mítico, do imaginário, do irracional que a epistemologia racionalista expurgou. (op cit, p.31).

Num exercício de associação livre as primeiras respostas sobre cotidiano seriam muito provavelmente aquilo que é habitual, banal, corriqueiro. Esses adjetivos podem induzir a pensar em algo pouco importante. Seguindo esse raciocínio, seria o esporádico, o eventual, o ocasional o mais importante? Compartilhamos da idéia de que é justamente a "repetitividade" dos fatos, dos acontecimentos é que são importantes. É a "repetitividade" cotidiana, que num esforço de análise ou de obsenação percebemos nem tão repetitivo assim, que incita em nós o desejo, a vontade, a necessidade de mudar. Daí o imperativo de sistematizar o cotidiano e analisar por outro viés aquilo que parece sem importância, banal ${ }^{4}$, de senso comum.

A análise de todo objeto de estudo científico está intimamente ligada com as práticas e perspectivas do investigador, o que significa dizer que distância entre objeto e pesquisador não deve ser ao nosso entender grande, o que garantiria "neutralidade" à pesquisa científica. Contudo, também não deve ser o seu oposto, isto é, uma total proximidade capaz de distorcer ou embotar o olhar para aspectos e questões de relevância da realidade pesquisada. A esse respeito Lefebvre se pronunciou:

Para conceber o cotidiano, para tomar em consideração a teoria da cotidianidade há algumas considerações preliminares: primeiro fazer um estágio, viver nela - em seguida rejeitá-la e tomar uma distância crítica. A ausência dessa dupla condição torna impossível a compreensão e suscita os mal-entendidos. A partir deste ponto, o

\footnotetext{
${ }^{4}$ Para Milton Santos "a cidade grande é um enorme espaço banal, o mais significativo dos lugares. Todos os capitais, todos os trabalhos, todas as técnicas e formas de organização podem aí se instalar, conviver, prosperar. Nos tempos de hoje, a cidade grande é o espaço onde os fracos podem subsistir." (2002,p.322)
} 
discurso sobre o cotidiano dirige-se a surdos, dos quais os piores são aqueles que não querem ouvir (p.82) 5 .

Ademais, um objeto da realidade, por "comum" que seja, somente será elevado à categoria de ciência de acordo com as incursões e comprometimento que o investigador tem com e à respeito desse objeto e, portanto, com a construção do conhecimento sobre o mesmo.

A esse respeito, Petersen considera:

Os dados empíricos, os fatos, certamente possuem uma existência real, mas só são cognoscíveis como respostas a perguntas, através das quais adquirem sentido. Não um sentido imanente a eles, mas um sentido atribuído pela intervenção do investigador. Os mesmos materiais, os mesmos fatos, a mesma cadeia de relações e condições históricas podem ser significadas diferentemente, dependendo das questões que são formuladas, do contexto em que o investigador coloca sua pergunta ${ }^{6}$. Só o investigador tem o poder de selecionar, entre os muitos sentidos possíveis, os que vão significar o fato. Nisto está incluída sua condição de ser social, com seus conceitos organizadores, com suas experiências e expectativas. A consciência que atribui significado aos fatos sofre os efeitos das experiências a que está sujeito o ser social e esta experiência é determinante no sentido de que exerce pressão sobre a consciência social existente, coloca novas questões e proporciona grande parte do material de base para exercícios intelectuais mais elaborados. $\mathrm{O}$ mundo real irrompe e coloca ao investigador questões ainda não articuladas: frente a elas os velhos sistemas conceituais podem ser derrubados e se imporem novas problemáticas. (op cit,33).

Sobre conceituações e novas problemáticas, inferimos que o cotidiano, não como adjetivo para designar a vida de todos os dias, mas como categoria explicativa de um modo de vida e de um momento específico na história, portanto, de uma espaço-temporalidade, carece de conceituação. Todavia, o fenômeno é sempre mais rico que o conceito e embora o desafio esteja colocado, atentamos ao leitor que ao fazêlo, não esgotamos de maneira alguma as acepções que podem e devem decorrer em relação ao cotidiano.

5 LEFEBVRE, Henri. A vida cotidiana no mundo moderno. Tradução de Alcides João de Barros. São Paulo:Ática, 1991.

6 Grifo nosso. 


\section{Percursos e percalços: correntes teóricas adotadas.}

Situamos o leitor no tocante às recorrentes correntes teóricas que se debruçam sobre o tema e nossa posição frente a elas, visto que são inúmeros os caminhos e ciências que dedicam-se a seu estudo. Num primeiro momento dessa pesquisa tínhamos a intenção de verificar todas elas, no intuito de percorrer "toda" produção bibliográfica que senvisse para nos amparar. No entanto, à medida que o processo de pesquisa foi se desenrolando, essa ambição foi abandonada, uma vez que investigar toda a produção bibliográfica acerca do cotidiano e suas diferentes concepções de método e metodologia mereceria por si só uma única e riquíssima pesquisa. Tal opção poderia ter sido feita, em detrimento de deixar de lado os outros propósitos desse trabalho. Assim, eleger buscar um panorama acerca dos estudos sobre o cotidiano sem relacioná-lo a um espaço geográfico, a um "território" e este à totalidade, recairia a nosso ver "apenas" num exercício epistemológico.

Sem entrar no mérito dessa questão, mas apenas para como dissemos situar o leitor, dentre as ciências que se dedicam ao estudo do cotidiano estão a Filosofia, a História, a Sociologia, a Antropologia, a Psicologia Social, a Geografia, a Lingüística. Uma incursão em todos esses campos exigiria de nós uma erudição que não possuímos, e insistir nesse caminho teria sido negligente para não dizer suicida.

Desse modo, escolhemos alguns autores para tratar do tema, e o primeiro critério para essa escolha recaiu sobre aqueles que apareceram em nossa trajetória antes mesmo de iniciada essa pesquisa, pois, esse foi um indicador de que tais estudiosos, seus métodos e metodologias estavam mais relacionados à ciência geográfica e seu modo de compreender a realidade.

Não nos detivemos, porém em um único grupo de autores de uma determinada postura ideológica, por considerar que as ciências humanas não são uma "camisa de força”, permitindo incursões em obras de autores que julgamos nos apoiar quer por seu método, quer por sua metodologia. Assim, não buscamos uma abordagem "perfeita" que se encaixasse ao nosso estudo, mas buscamos compreender diferentes enfoques para o mesmo fenômeno que à medida que iam sendo desvendados, iam-se mostrando significativos para o estudo proposto. Tivemos para isso cuidado em filtrar, escolher, depurar, aquilo que de cada enfoque/abordagem nos serviria para elucidar os questionamentos, afim de não comparar coisas incomparáveis, ou de separar coisas inseparáveis.

Salientamos ainda que o processo de conhecimento não está a priori estabelecido, mas é um constante caminho a percorrer considerando todas as dúvidas, dificuldades e limites. O que se segue é resultado desse movimento. 
Apresentamos alguns teóricos da vida cotidiana e identificamos suas respectivas correntes ideológicas. Dentre os autores de inspiração marxista estão Henri Lefebvre, Karel Kosik, Agnes Heller e Gyorgy Lukacs. No campo da sociologia compreensiva, de orientação fenomenológica estão Michel Maffesoli e Alfred Schutz. Entre os historiadores estão Jacques Le Goff, e Michel de Certeau (Petersen, 1995 p. 51).

Os estudos do cotidiano ocuparam grande parte da empreitada intelectual de Henri Lefebvre, por esse motivo nosso diálogo se estabelece fundamentalmente com este autor. Tendo se dedicado a questões relacionadas à lógica, à dialética, ao modo de vida urbano, à arquitetura, dentre outros assuntos, há em vários de seus trabalhos uma preocupação espacial que perpassa os argumentos com os quais trabalha, e nisso seu apoio à ciência geográfica é elementar.

Agnes Heller formula que todo o indivíduo é sempre simultaneamente, ser individualparticular e ser humano-genérico, ou seja, suas preocupações, seu modo de relacionar-se com o mundo e com as coisas estão ligados às suas aspirações individuais, particulares que dizem respeito a si mesmo, mas também e concomitantemente são aspirações genéricas, de todo homem, como por exemplo, o trabalho socialmente necessário para reproduzir-se. Tal contribuição é importante para nós à medida que nos interessa o indivíduo, mas não esse ser isolado, ao contrário, interessa-nos em sua coletividade. Nesse trabalho, expressa através de suas aspirações, relações com outros indivíduos e basilar para nossa análise, suas relações com o espaço habitado, no nosso caso o que denominamos de Conjunto Habitacional Parque Continental. Também importante para nosso estudo é a noção de alienação desenvolvida por essa autora.

Outros autores fazem parte desse diálogo e nos ajudam a construir um caminho menos tortuoso em relação a uma formulação da vida cotidiana.

Henri Lefebvre vale-se do legado marxista, que não se resume ao materialismo dialético como sistema filosófico ou a uma teoria de economia política, para compreender o termo produção num sentido maior do que aquele conhecido até então pelos estudiosos da obra marxista. Para ele, a produção não se reduz à fabricação de produtos, materiais e coisas. Mas, diz respeito ainda à produção do tempo, espaços, e mais ainda, implica a produção do próprio ser humano e de suas relações sociais. Enfim, tomado em toda a sua amplitude, o termo envolve a reprodução. $(1985,1991)$. 
Daí nossa primeira aproximação no intuito de conceituar o cotidiano como um modo de vida de um momento específico da história, qual seja, o desenvolvimento do modo de produção capitalista e todas as implicações decorrentes desse processo.

É sabido das contribuições de Marx para a compreensão do modo de produção capitalista que sua base material é constituída pelas forças produtivas (ferramentas, máquinas, as técnicas, tudo o que permite a produção) e, também, por relações entre os proprietários dos meios de produção: as terras, as matérias primas, as máquinas - e aqueles que possuem apenas a força de trabalho: os trabalhadores. O conjunto dessas forças impulsiona a sociedade e sem entender seu desenvolvimento o exercício de compreensão do cotidiano se esboroa.

Em artigo escrito em 1973, Lefebvre ${ }^{7}$ traz importante contribuição ao localizar a preocupação de Marx com a reprodução das relações sociais (de produção). Para ele tal conceito aflora na obra marxista a partir do momento da formulação do conceito de sistema (modo de produção capitalista). Para Lefebvre, Marx nunca especificou completamente tal conceito e, somente no fim de sua atividade teórica é que surge a compreensão do problema das relações capitalistas de produção que não coincidia com os problemas da sua gênese e da sua exposição (1985,p.219).

A formação do capitalismo pressupõe analisar a produção e a reprodução dos meios de produção (forças produtivas constituídas pelos trabalhadores e os instrumentos de trabalho). Os trabalhadores têm de reproduzir-se (ter filhos, alimentá-los, educá-los, torná-los capazes, por sua vez, de trabalhar). Daí o imperativo da formulação da reprodução das relações sociais.

Ainda no referido artigo, Lefebvre chama atenção para o ciclo do D-M-D funcionando sempre para a manutenção do sistema capitalista. O autor sinaliza que esse ciclo só deixa de ocorrer numa situação de crise ou revolução proletária. Embora não haja crise propriamente dita nesse sistema de produção, nem tão pouco revolução proletária, as relaçães sociais do modo de produção capitalista passam por transformações. Mais adiante, Lefebvre salienta a resistência do sistema a crises ou convulsões revolucionárias, em virtude de possuir uma elasticidade e capacidade de organização imprevistas (op. cit, p.222).

De acordo com esse autor em carta dirigida à Engels, em 1863, Marx julga que a produção não se resume apenas na circulação de bens e dinheiro. Mostra de que modo e porque razão o processo não se interrompe, pois reproduz as suas próprias condições. (idem).

\footnotetext{
7 LEFEBVRE, Henri. Estrutura social: a reprodução das relaçães sociais. In: Sociologia e sociedade (Leituras de introdução à Sociologia). FORACCHI, Marialice Mencarini \& MARTINS, José de Souza (orgs).Rio de Janeiro: LTC - Livros Técnicos e Científicos. 1985 (10ª edição).
} 
Isto é central para nossa discussão, pois encontramos relação entre o modo de produção capitalista e o cotidiano (onde as condições da reprodução se produzem).

(...) O cotidiano, e não já o econômico em geral, é a base sobre a qual se pode estabelecer o neocapitalismo. Ele estabeleceu-se no cotidiano como solo, isto é, em terra firme, substância social conservada por instâncias políticas. Implícito originariamente em Crítica da vida cotidiana, o conceito da reprodução das relações sociais torna-se perfeitamente nítido pelo confronto entre a análise crítica do cotidiano, a dos fenômenos urbanos, a do crescimento econômico e do economismo, domínios relacionados entre si ${ }^{8}$. (...) (p.230).

À medida que o capitalismo foi se delineando, essencialmente após a Revolução Industrial no século XVIII, em virtude do surgimento e concomitante desenvolvimento das máquinas e das técnicas, os trabalhadores ferreiros, artesãos, sapateiros, marceneiros e etc vêem seus ofícios ameaçados, e com isso também seu poder de troca e negociação com aqueles que passaram a deter os meios de produção e constituem na Inglaterra de então aquilo que nos séculos posteriores assiste-se em todo o mundo capitalista: o exército industrial de reserva, destituído dos seus meios de produção e sempre a espera de colocação no mercado de trabalho.

As relações de produção encerram contradições, nomeadamente as contradições de classe (capital/salário) que se amplificam em contradições sociais (burguesia/proletariado) e políticas (governantes/governados). Mostrar como se reproduzem as relações de produção não significa que se sublinhe uma coesão interna do capitalismo; isso quer dizer, também e sobretudo, que se mostra como se amplificam e aprofundam, em escala mundial, as suas contradições. Sobrepor o modo de produção às relações de produção como a coerência à contradição, essa atitude de uma "prática teórica" tomada em separado tem apenas um sentido: liquidar as contradições, excluir os conflitos (ou pelo menos certos conflitos essenciais), camuflando o que sucede e o que procede desses conflitos. (p.233)

Da citação acima, inferimos que nas contradições das relações de produção assistimos sempre vantagens dos primeiros - capital, burguesia, governantes, sobre os segundos - salário, proletariado, governados. Diante de tal fato, e conforme já assinalamos neste trabalho, se estão "diminuídos" os processos produtivos e a inserção do proletariado no "chão" da fábrica, são as reproduções das relações de produção (no sentido amplo do termo) e suas contradições que são 0 alvo de nossa investigação. E nossa incursão se fará por meio do cotidiano.

Analisemos sucintamente como se deu esse processo no Brasil.

8 Grifo nosso. 
A história brasileira, desde o início de sua colonização, foi marcada pela concentração de terras, sendo sempre dificultado ao camponês e ex-escravo (sinônimo de trabalhador livre), o acesso a este meio de produção, o que trouxe como conseqüência a manutenção de uma grande parcela da população rural brasileira desprovida de terras e recursos, levando-a a dispor da única fonte de riqueza que possuía - a sua força de trabalho. A Lei de Terras de 1850 (que determinava o acesso à terra somente mediante a contrapartida financeira) aumenta ainda mais a dificuldade de inserção dos trabalhadores rurais no processo de produção. Na primeira metade do século XX, a emergência do ciclo econômico-produtivo baseado na cultura cafeeira contribui fundamentalmente para a urbanização brasileira, com destaque para a região Sudeste do país, sobretudo os estados do Rio de Janeiro, São Paulo e Minas Gerais, que se tornou o maior pólo de desenvolvimento nacional.

A expansão do capital junto à agropecuária brasileira, a partir da década de 1960, acelerou as mudanças nas condições materiais de produção e outras relações de trabalho surgem entre grandes fazendeiros e camponeses como o colonato e a parceria. Aos que nem isso conseguiam restava a tentativa de permanecer no campo e lutar no limite de suas forças contra o grande capital ${ }^{9}$ ou migrar para as cidades em busca de melhores oportunidades, vislumbradas a partir dos planos de governo de Juscelino Kubstichek de modernizar e industrializar o Brasil.

Os problemas estruturais e infra-estruturais de outras regiões do país e a estruturação da região Sudeste como core área do país fez surgir na década de 1970 um imenso movimento de migração interna para essa "terra de promissão". No entanto, após a década de 1980, conhecida como década perdida e o período neoliberal iniciado nos anos 1990, a região Sudeste passou a não mais absorver economicamente ${ }^{10}$ toda a população migrante. O refluxo da industrialização, principalmente da cidade de São Paulo e arredores, e o desemprego estrutural decorrente disso, não diminuíram o expressivo contingente que continuava aportando à cidade em busca de outras ocupações. A partir daí, assistimos o inchaço das favelas e a proliferação de áreas periféricas distantes das áreas centrais em que predominam o processo de autoconstrução de habitaçães. É nesse contexto também, que surgem as tentativas do poder público de corrigir e/ou diminuir o déficit habitacional gerado pela leva crescente de migrantes e moradores da própria cidade, não detentores de renda suficiente para adquirirem uma habitação, por modesta que fosse.

9 É nesse contexto que surgem no Brasil os movimentos sociais do campo, que tem sua maior expressão no Movimento dos Trabalhadores Rurais Sem Terra (MST).

10 Referimo-nos à economia formal. 
Os novos territórios resultantes dessas políticas ${ }^{11}$ criaram também nas grandes cidades, e especificamente na cidade de São Paulo, novas e interessantes formas de apropriação do espaço urbano. Mescla de permanências trazidas dos primeiros lugares de moradia dos moradores e transformações no que tange às suas relações com esse novo lugar, sua representação com essa forma de morar. A área escolhida para o presente estudo é constituída por meio de específicas políticas de provisão de habitação, de acordo com o que veremos nos próximos capítulos.

É sabido que nessas áreas o índice de desemprego é grande. Todavia tal termo não é para nós sinônimo de desocupação. Nessas áreas, a ausência de trabalho formal não implica necessariamente falta de trabalho. Entendemos como tal, qualquer ocupação, função, atividade, e não fundamentalmente trabalho formal reconhecido pela sociedade, pois, a parcela de menor renda, habitante por excelência dessas áreas descobre a cada dia formas inéditas de trabalho e luta. ${ }^{12}$ Longe das fábricas ${ }^{13}$, perto das moradias, nas habitações e nas ruas, as relações de senviço e não necessariamente de produção (no sentido estrito do termo) é que dão sustentação a muitos indivíduos fora do circuito formal da economia. São exemplos dessas ocupações: pedreiro, catador de papelão, pintor, costureira, cabeleireira, barbeiro, manicura, pedicura, empregadas domésticas, babás, traficantes de drogas ilícitas, pequenos comerciantes de doces, bebidas alcoólicas, salgados e sanduíches, bicheiros etc ${ }^{14}$. Note-se que são atividades fundamentais para o exercício de sociabilidade, identidade, intimidade e enriquecedoras das relações sociais entre as pessoas ${ }^{15}$, são, portanto, inerentes à (re) produção (no sentido amplo do termo) desses sujeitos; e são também, produtoras de valor monetário, por ínfimo que seja.

Se São Paulo é a cidade global como discute Saskia Sassen, inserida que está nas redes que se constituem, no período técnico-científico-informacional, e por tal motivo centro de negócios ancorados nas redes técnicas e informacionais, nela vivem pessoas que embora saibam de sua complexidade, não convivem diretamente com tais técnicas. "Diante delas, pobres e migrantes são passivos, como todas as demais pessoas. É, portanto, na esfera da comunicação que eles, diferentemente das classes ditas superiores, são fortemente ativos". (Santos, 2002, p.326).

\footnotetext{
${ }^{11}$ Atentamos para as diferenças entre as políticas tanto no que respeita á tipologia: prédios de apartamentos, casas térreas ou assobradadas, quanto no que respeita as formas de propriedade: concessão de uso, financiamento, arrendamento, doação de lotes urbanizados, etc.

${ }^{12}$ Analisaremos detidamente essas formas de ocupação no Capítulo 3 deste trabalho, quando nos ocuparemos em investigar as práticas cotidianas dos moradores.

${ }^{13}$ Até porque os empregos fabris extinguem-se e quando são oferecidos o são para trabalhadores qualificados. Em contrapartida há atualmente nas cidades um aumento considerável de atividades comerciais e de serviços.

${ }_{14}$ A figura do bicheiro comumente é pouco conhecida, certamente por essa atividade ser considerada ilegal. Restando nessas áreas somente um "funcionário" e uma barraca onde o jogo funciona.

15 São atividades que servem essencialmente aos próprios moradores da área.
} 
Para esse autor, trata-se da força dos homens $\operatorname{lentos}^{16}$ e não daqueles que detém a velocidade técnica-informacional (op.cit, p.325). No entanto, essa afirmação requer uma relativização, pois, os benefícios do período técnico-científico muitas vezes também beneficiam a parcela de menor renda da população. Ocorre que para esses indivíduos, importa que tais benefícios como aparelhos, equipamentos, e produtos funcionem, não importando como funcionam. É desnecessário sabê-lo!

Carlos (2004) parte do pressuposto de que as relações sociais se realizam, concretamente, na forma de relações espaciais - constituindo-se ao mesmo tempo prática. Nesta direção, a reflexão sobre a cidade é fundamentalmente, uma reflexão sobre a prática socioespacial que diz respeito ao modo pelo qual se realiza a vida na cidade, enquanto formas e momentos de apropriação (p.7). No cotidiano, pois, e aqui encontramos importante contribuição que relaciona esse nível de análise ao espaço construído pelo homem (objeto per si da Geografia). Para essa autora a prática socioespacial dá conteúdo à vida cotidiana, enquanto nível determinante que esclarece o vivido, na medida em que a sociedade produz o espaço, apropriando-se dele, dominando-o.

Desta análise resulta que o lugar da reprodução das relações de produção não localizase na empresa, no local ou nas relações de trabalho. Toda a sociedade toma-se o lugar da reprodução, e além dela todo o espaço é seu lugar.

Assim, as forças produtivas permitem aos que as detêm que disponham do espaço $e$ venham até a produzi-lo. Esta capacidade produtiva estende-se ao espaço terrestre e transborda-o; o espaço social natural é destruído e transformado num produto social pelo conjunto das técnicas, desde a Física à informática. Mas este crescimento das forças produtivas não pára de gerar contradições específicas que reproduz e agrava Lefebvre (1985, p.247). Veremos, no entanto, que o espaço também é produzido pelos homens lentos não detentores das forças produtivas, mas detentores de uma série de outras artimanhas.

${ }^{16}$ Grifos do autor. 


\section{Sobre a metodologia do trabalho de campo}

O trabalho de campo da pesquisa estabelecido a priori, quando percebido insuficiente para as análises necessárias foi complementado no decorrer do processo de investigação.Desse modo, mesmo considerando imprescindível a interlocução com os moradores, julgamos que essa interlocução não deveria ser homogênea, linear e única. Por essa razão, nossas intervenções no Conjunto aconteceram de maneira não convencional, pois perpassaram as concessões de entrevistas e registro fotográfico, pois inúmeras outras dinâmicas ocorriam ou estavam na iminência de ocorrer ali, mas para apreendê-las deveríamos adotar outras posturas. Dessa maneira, optamos por valer-nos de nosso conhecimento e experiência junto ao processo de constituição do Conjunto. Conforme bem salientou A. Rodrigues (1988) ao comentar sua metodologia de pesquisa: "o objetivo desta pesquisa não é definir uma única forma de metodologia, mas de abrir "brechas" na Geografia e propor também indicações para a compreensão da produção do espaço em sua cotidianidade e na sua possibilidade de ação imediata". (p.12) Essa foi a nossa tentativa.

Significa dizer que não só as entrevistas concedidas transformaram-se em rico material para nossa análise, mas os diálogos "informais" com os moradores, foram também fundamentais para nos ajudar a desvendar muitas de suas práticas, e entender aspectos não relacionados diretamente com o processo de conquista da moradia e transferência das antigas residências para o espaço do Conjunto Habitacional Parque Continental.

Por isso, além da interlocução com moradores precursores no sentido de resgatar a história da implantação do Conjunto Habitacional, nossa preocupação foi decodificar inúmeras observações, idéias, desabafos, percepções, e opiniões de moradores de perfis variados: crianças, jovens, adultos, anciãos. Donas de casa, estudantes, autônomos, desempregados, subempregados. Religiosos, pagãos e indiferentes. Esse procedimento metodológico diverso complementado por conversas, participações, escutas e observações só foi possível em virtude da constância de nossa presença e que permitiu também testemunhar batidas policiais, fugas, discussões, brigas, festas, velórios, reuniões, festival de futebol, etc. Os procedimentos tradicionais embora indispensáveis não foram suficientes para captar a heterogeneidade e a ambigüidade de situações e significados. Pelo mesmo motivo não priorizamos e não estabelecemos quantidade de questionários aplicados e/ou conversas com os moradores. 0 que julgamos pertinente, porém, dada a dinâmica e complexidade dos acontecimentos, foi 
estarmos atentos durante todo o processo da pesquisa para eventuais interlocuções que ainda se fizessem necessárias.

\section{Estrutura dos capítulos}

No primeiro capítulo, apresentamos brevemente o Jaguaré, distrito em que situa se o conjunto habitacional, objeto desse estudo. Projetado na década de 1930 por Henrique Dumont Villares para ser um parque industrial, o bairro foi ao longo das décadas ocupado desordenadamente. A partir de 1990, começa a ocorrer a ocupação "ordenada" das políticas municipais de habitação em algumas frações do bairro. Partirmos daí para o estudo de uma dessas políticas idealizada por Luiza Erundina de Souza, mais precisamente, o Programa de Produção de Unidades Habitacionais em Mutirão e Autogestão e o histórico de formação do Mutirão Estrela Guia, contado por moradores participantes do processo de construção e implantação.

No segundo capítulo, apresentamos a política municipal de habitação da administração de Paulo Maluf, continuada na administração posterior de Celso Pitta. Verificamos como foram implantadas no município de São Paulo as Operações Interligadas (especificamente a contrapartida dessa Parceria Público Privada) expressa em habitações populares e o Programa de Verticalização e Urbanização de Favelas. A união dos três programas na mesma área gerou o "território cotidiano" que denominamos nesse trabalho como Conjunto Habitacional Parque Continental. Para traçar o histórico do Cingapura Parque Continental, também contamos com a interlocução de moradores precursores. Tanto no primeiro como no segundo capítulo, interessa a gênese das políticas, sua concepção, execução; e a participação ou não dos moradores no processo.

No terceiro e último capítulo, discutimos a vida cotidiana dos moradores: suas relações com o espaço habitado, a identidade e o estranhamento com o lugar de morar, a percepção desse, a relação espaço público x espaço privado - tão premente nos conflitos existentes entre os moradores. As transformações e permanências por que passa o Conjunto e as perspectivas dos residentes. 
Na conclusão, traçamos um balanço em tomo dos resultados do trabalho, discutindo principalmente se as hipóteses elaboradas foram corroboradas ou não, e apontamos aspectos de rico significado para a reflexão proposta com destaque no processo da pesquisa, ainda que não tenham feito parte de nossos propósitos iniciais. 
Território do cotidiano: Constituição a partir da política de habitacão de Luiza Erundina de Souza.

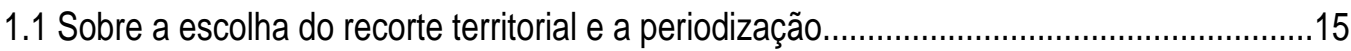

1.2 Jaguaré - Do distrito industrial ao loteamento Parque Continental...................................16

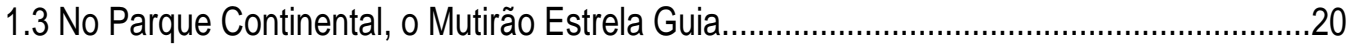

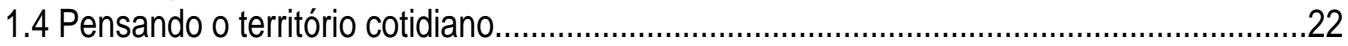

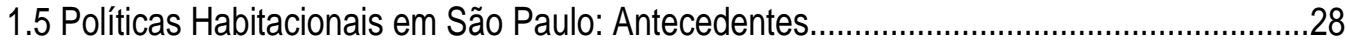

1.6 A política de provisão de habitação na administração Luiza Erundina...............................31

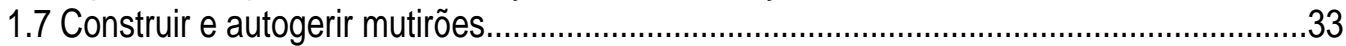

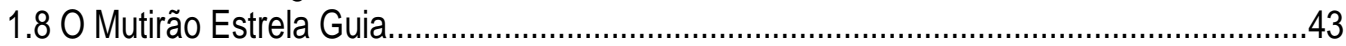

1.9 Autoconstrutores: Entre ideais, conquistas e frustrações................................................45

1.1 Sobre a escolha do recorte territorial e a periodização.

No âmbito dessa pesquisa, a escolha do recorte teritorial foi feita a priori, e a periodização a posteriori, a partir do que o recorte teritorial suscitou em termos de análise. Significa dizer que por tratarmos de políticas muito espećíficas no que respeita ao setor de habitação na cidade de São Paulo, a periodização feita por nós é também específica. Acreditamos que a escolha de um recorte teritorial é um tipo de periodização, ou seja, estudar um determinado fragmento de espaço na metrópole é também na mesma medida, investigar o período em que este fragmento foi produzido.

Dito de outra forma, periodizar implica entender certa produção do espaço urbano, desse modo, apresentando as referidas políticas para compreender a área da pesquisa, entenderemos também outras parcelas do espaço da metrópole paulistana, produzidas por meio do mesmo processo, no mesmo período, ainda que guardem suas especificidades.

Milton Santos refere-se a periodizações como segue:

Períodos são pedaços de tempo submetidos à mesma lei histórica, com a manutenção das estruturas. Estas se definem como conjuntos de relações e de proporções prevalentes ao longo de um certo pedaço de tempo, e nos permite definir nosso objeto de análise. Assim as periodizações podem ser muitas, em virtude das diversas escalas de observação. (1994, p.79).

Para ele, diferentes escalas (mundo, nação, cidade) permitem diferentes periodizações (idem). Partindo desse pressuposto, estamos trabalhando com a periodização de políticas de habitação no município de São Paulo. E por esse motivo, deteremos especial atenção ao período de pouco mais de uma década (1989 a 2000), que corresponde às três administrações municipais que implementaram as 
políticas de habitação foco de nossa análise (Mutirões autoconstruídos e autogeridos, Operações Interligadas e o Projeto Cingapura).

É imprescindível lembrar a importância e a complexidade com que o tema da habitação popular é tratado no meio literário ${ }^{17}$. É possível abordar esse assunto sob vários ângulos: aspectos socioeconômicos, jurídicos, arquitetônicos, psicossociais etc... Sendo impossível desconsiderar essas contribuições, inclusive pelo teor das análises é que justificamos a presença dos subsídios dessas diversas áreas no nosso trabalho.

1.2 Jaguaré - Do distrito industrial ao loteamento Parque Continental.

O distrito do Jaguaré localiza-se na porção ocidental da cidade de São Paulo, nos limites com o município de Osasco e próximo à confluência do rio Pinheiros com oTietê. É o que pode ser observado no Mapa de Localização (p. 19)

No início da década de 1930, uma extensa área do atual distrito do Jaguaré foi projetada pelo engenheiro agrônomo Henrique Dumont Villares para ser um distrito industrial. Dentre as características que o influenciaram a investir nessa área estavam: a distância de $12 \mathrm{~km}$ do centro urbano de São Paulo (na época considerada uma pequena distância); a conexão com as estradas de ferro do Estado de São Paulo e fundamentalmente, a proximidade com a estrada de ferro Sorocabana, uma vez que as ferrovias eram importantes vias de escoamento de produção àquela época18. Também as rodovias em direção ao interior do Estado estavam próximas ao loteamento. Considerava Henrique Dumont Villares que o Centro Industrial do Jaguaré situado onde estava, seria ponto de passagem obrigatório, tanto para importações como para exportações e, portanto, estariam facilitadas as relações comerciais com os Estados do Rio Grande do Sul, Mato Grosso, Paraná, Goiás, Rio de Janeiro e Minas Gerais, pois, para ele a facilidade de colocação dos produtos em mercados apropriados através dos transportes era essencial às mercadorias produzidas pelas indústrias no seu loteamento.

Ainda no que diz respeito à localização do empreendimento de Villares, é imprescindível destacar que as obras de retificação do rio Pinheiros foram fundamentais para a

${ }^{17} \mathrm{O}$ tema da habitação popular é interesse de engenheiros, arquitetos, planejadores, sociólogos, geógrafos, historiadores, dentre outros.

18 Ver VLLARES, Henrique Dumont. A indústria em São Paulo. (Estudo para a sua localização). Centro Industrial Jaguaré.São Paulo, 1939. 
criação de novas áreas no espaço urbano da cidade de São Paulo, em virtude do processo de aterramento de suas áreas de várzea ${ }^{19}$.

Pode-se dizer que o bairro existe graças às obras de retificação dos rios Pinheiros e de seus formadores (o Grande e o Guarapiranga), feita tendo emvista o aumento do potencial do reservatório Billings. O leito do rio Pinheiros era sinuoso e de fraca declividade, percorrendo uma várzea freqüentemente inundável. Até a retificação o Pinheiros marcava, de certa forma, o limite do aglomerado urbano da capital, pois, a oeste da várzea inundável - excluídos os centros afastados, como Osasco, por exemplo, só havia residências isoladas e pequenas instalações industriais.(GOLDENSTEIN \& ROSSINI, 1972)

O loteamento adquirido por Henrique Dumont Villares constituía-se então das áreas de várzea aterradas reservadas para as indústrias e fábricas, e colinas terciárias suavizadas reservadas para a zona residencial do distrito industrial. (idem). Na década de 1960, portanto 30 anos depois de iniciadas as vendas dos lotes, o setor industrial desse distrito contava com indústrias mecânicas e metalúrgicas, materiais de construção, serrarias, alimentícias, químicas, têxteis, papel e papelão, eletrônicas ${ }^{20}$.

Estavam claras as iniciais intenções de Villares para o distrito industrial do Jaguaré, "porém o espaço urbano embora previamente organizado, teve uma ocupação caóticą1", fundamentalmente no que respeita às ocupações residenciais, donde nosso interesse.

As avenidas Jaguaré e Presidente Altino foram os primeiros centros irradiadores da população e as atividades de comércio e senviço desenvolveram-se nos arredores da praça Henrique Dumont Villares, segundo Goldenstein \& Rossini (1972), área mais antiga do aglomerado, que se situa no entroncamento da avenida Presidente Altino e avenida Bolonha.

Vejamos o que nos dizem sobre a origem do primeiro núcleo de favela do Jaguaré:

Parte da área destinada às residências é ocupada por área verde, com predomínio de eucaliptos; fica no contato com a zona industrial de leste e se estende até o rio Pinheiros. É um parque em mal estado de conservação, sem nenhuma função recreativa, que está sendo depredado para retirada de terra, aparentemente destinada a aterros. (p.59). Com a depredação do bosque, esta área, que pertence à Prefeitura, tornou-se uma favela. Em 1968 a favela estava sendo intensamente trabalhada por senviços assistenciais diversos. Muitos dos velhos barracos foram reconstruídos e é extremamente dificultada a fixação de novas famílias. É chamado

\footnotetext{
${ }^{19}$ É necessário lembrar também que as áreas de várzea dos rios Pinheiros e Tietê contribuíram não somente para novas ocupações residenciais, como também os clubes de regatas e outros empreendimentos, como inclusive para a constituição das avenidas Marginais de ambos os rios, importantíssimas vias de acesso da metrópole paulistana.

20 Muitos desses setores industriais ainda estão presentes no referido distrito, no entanto, cabe ressaltar o significativo número de empresas transportadoras, sobretudo ao longo da avenida Presidente Altino, em direção ao bairro de mesmo nome.

${ }^{21}$ lbidem.
} 
de Vila Nova Jaguaré, e congrega mais de 370 famílias, tem uma escola (também de madeira) com duas classes. (p.70)

Concluímos a partir disso, que a favela Nova Jaguaré é a expressão do desordenamento da parte residencial do loteamento previsto por Henrique Villares. Acrescente-se que ao longo do tempo a favela expandiu-se imensamente e a escola referida no trecho acima é atualmente a Escola Estadual João Cruz Costa. Também uma área da favela Nova Jaguaré foi objeto de intervenção do PROVER ${ }^{22}$ em fins da década de $1990^{23}$.

Ao longo das décadas, o bairro acompanhou o crescimento da metrópole como um todo e continuou a crescer, no entanto, devido às limitações físicas da área previamente planejada, o vetor de crescimento da área residencial apontava para os limites com o município de Osasco na direção sudbeste do loteamento. Surgem então dois novos loteamentos ampliando ainda mais a característica residencial do bairro. A área pertencente à Cia. Suburbana recebeu o nome de Vila Lajeado e, outra área situada nos limites de Osasco na confluência da Avenida Presidente Altino e Avenida Billings, pertencente à Cia. Urbanizadora Continental.

É nesse contexto que surge o Parque Continental, loteamento estritamente residencial destinado à classe média ascendente da década de 1960 e que, em fins da década de 1980, tem parte de sua gleba desapropriada para a construção de habitações de interesse social como parte de um programa da prefeitura paulistana para esse setor. Cercada por muros, a vila resultante do processo de construção de unidades habitacionais através de mutirão, recebe de seus fundadores o nome de Mutirão Estrela Guia. Em fins de 1990, em virtude de outro programa para o setor de habitação, um conjunto habitacional foi edificado na mesma área do Mutirão. Esse conjunto recebe o nome do loteamento inicial idealizado para a classe média: Conjunto Habitacional Parque Continental, ainda que a demanda para quem ele destinou-se foi à população de menor renda.

22 Ver cap II, p.73.

${ }^{23}$ Sobre o urbanismo proposto por Henrique Dumont Villares e seu contrário: a formação da favela Nova Jaguaré ver SILVA, Fávia Elaine. O Distrito Industrial Jaguaré pelo seu desvio: Urbanismo e Vida Cotidiana. Trabalho de Graduação Individual. Departamento de Geografia - FFLCH/USP. São Paulo:1998 


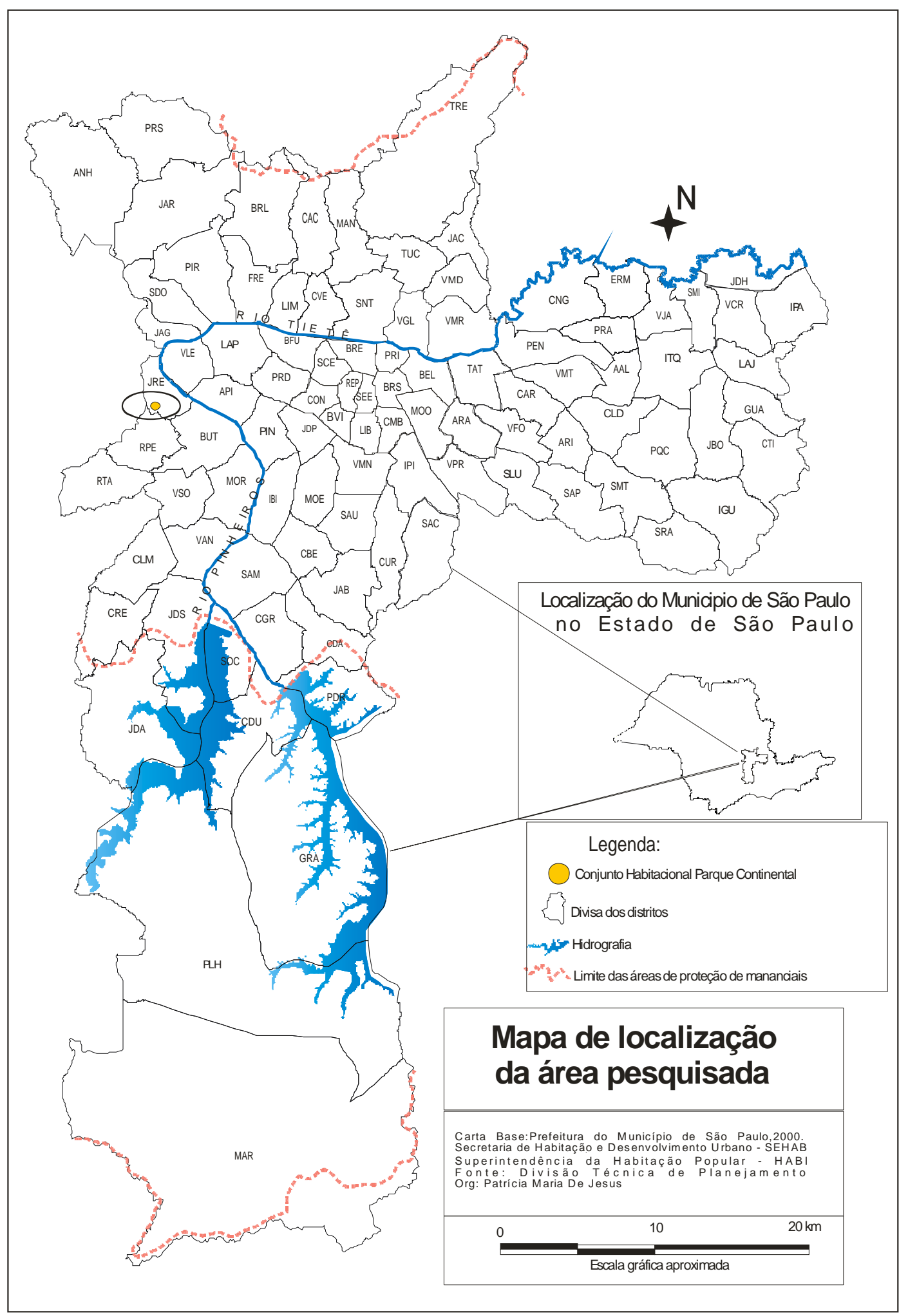


1.3 No Parque Continental, o Mutirão Estrela Guia.

Em texto escrito em 1991, Modena nos ajuda a desvendar a origem da gleba desapropriada para a construção do Mutirão e posterior construção dos empreendimentos das Operações Interligadas e do PROVER. Interessada que estava em apresentar o inédito advento de um shopping center na periferia da metrópole ${ }^{24}$ e as relações das pessoas com esse empreendimento, a autora nos informa sobre o Shopping Continental situado exatamente na divisa dos municípios de São Paulo e Osasco:

No extremo oeste da capital, o Parque Continental rompe a tradição e mostra a procura da classe média pelos limites da cidade. O Parque divide-se em duas partes - praticamente dois terços para São Paulo e um terço para Osasco. No final da década de 1960 a Urbanizadora Continental fez o loteamento do lugar e as intenções eram de fazer um condomínio fechado, algo como é hoje Tamboré ou Aldeia da Serra (...) Um clube foi construído para usufruto dos moradores que adquirissem um título e como, na época apenas um supermercado e uma padaria encarregavam-se de servir o lugar, a Continental e o grupo Yaham tomaram a iniciativa de arquitetar um shopping center para os moradores do bairro. A idéia, no entanto, foi quase um fracasso total. Parece que os moradores não gostaram muito da mistura com o pessoal dos bairros vizinhos e o shopping acabou perdido no meio de uma região heterogênea com casas luxuosas de uma classe média ascendente. (p.171).

Em fins de 1989 e início de 1990, a Prefeitura desapropria parte de uma grande gleba nas proximidades do Shopping Continental e inicia-se o Mutirão Estrela Guia.

Consta do relatório da Prefeitura Municipal:

A gleba inicialmente foi desapropriada com uma área de 218.348,00 m². Através de acordo nos autos, os proprietários doaram uma parte dessa gleba, perfazendo $29.732,00 \mathrm{~m}^{2}$, sendo que o restante da gleba não mais foi objeto de desapropriação.

São palavras de Cláudio (uma das lideranças da Associação Comunitária Estrela Guia na época da construção do Mutirão):

"Então até que um dia, o pessoal da Administração vem com informação de que tinha uma área no Parque Continental que estaria sendo decretada de Interesse Social e que a gente teria que estar no aguardo e de que naquela semana já teria definição, foi coisa muita rápida, então nessa questão foi a única prefeita que São Paulo teve que a gente ficou sabendo até hoje que teve essa coragem de você chegar em uma área nobre como essa daqui e você decretar área de Interesse Social para atender população de baixa renda. Um negócio assim inédito, então eu

24 O Shopping Center Continental foi construído em 1975. 
lembro que a gente ficou sabendo que o proprietário era o dono da Continental, da área do Shopping e toda a área do pessoal que mora no Parque (...). Até onde a gente sabe a Erundina pagou e passou a domínio municipal daí a gente iniciou 0 processo de mutirão. Foi marcado, fizemos a solenidade, aí teve a presença do bispo, todo o pessoal ligado à Administração, a Secretaria de Habitação na época também, aí fizemos uma missa campal, aliás, foi um ato ecumênico porque tinha o pessoal de outras religiões"25.

Concluímos a partir dessas três fontes que a extensão de terreno onde hoje está edificado o Conjunto Habitacional Parque Continental era uma área privada da Urbanizadora Continental que loteou a parcela do distrito do Jaguaré conhecida como Parque Continental. Provavelmente dívidas e/ou irregularidades com a Prefeitura Municipal levaram ao processo de desapropriação da área. Cabe acrescentar que ainda hoje parte da gleba, entre o Conjunto Habitacional e o shopping continua subutilizada, conforme mostra a Imagem 1 p.21.

Além do Shopping Continental e do Clube Parque Continental, o Parque Continental é atualmente provido de uma ampla rede de seniços (vídeo locadoras, academias, pizzarias, consultórios de fisioterapia, odontologia, escritórios de advocacia, supermercado, padaria, etc), e linhas de transporte coletivo municipal que conferem ao loteamento status de bairro.

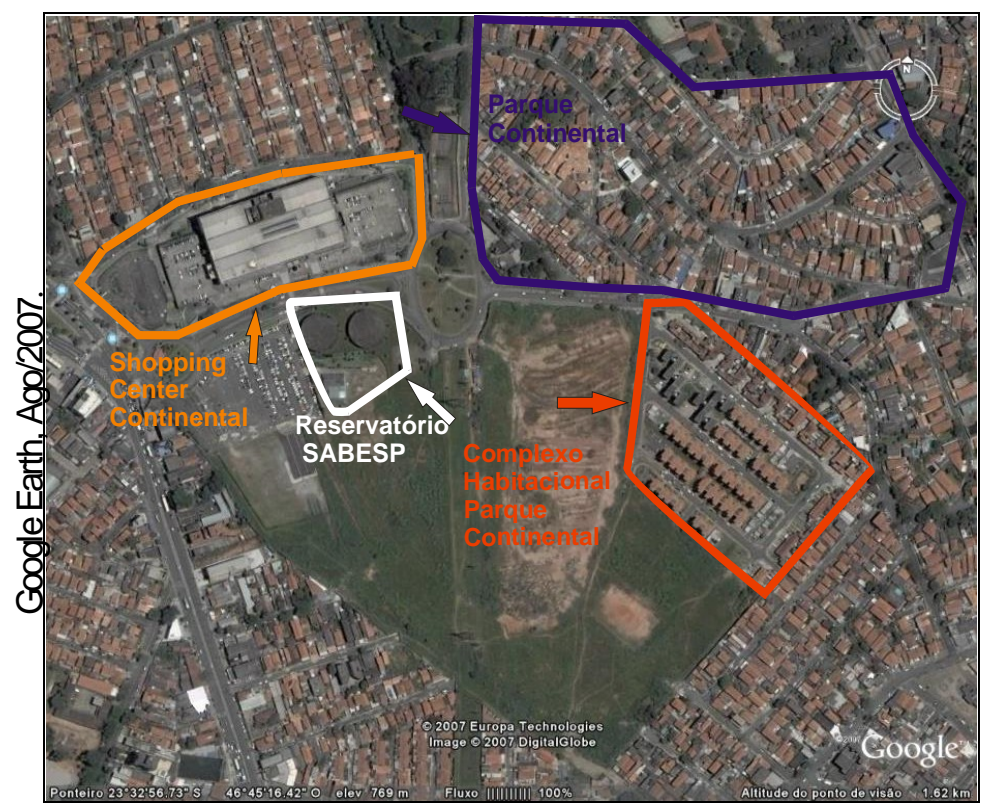

Imagem 1: Entorno da área do Conjunto Habitacional Parque Continental

25 Informação verbal concedida em entrevista realizada em 28/02/2007. 


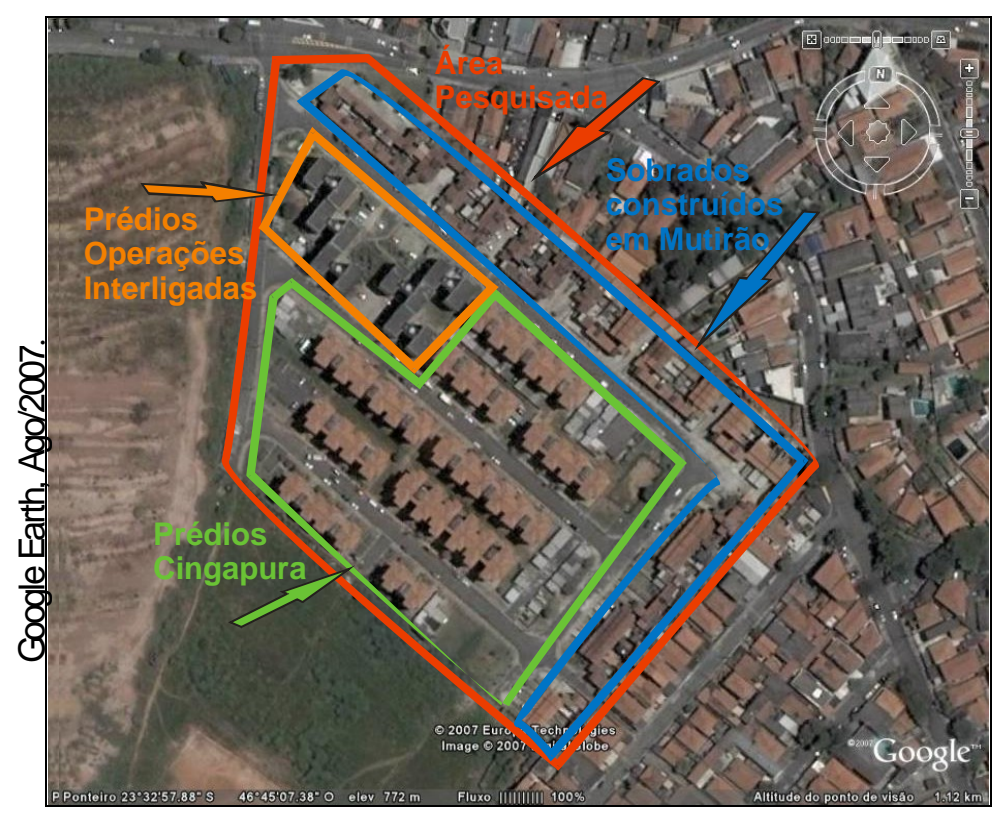

Imagem 2: Subdivisões da área do Conjunto Habitacional Parque Continental: edifícios Operações Interligadas, edifícios Cingapura e casas autoconstruídas.

\subsection{Pensando o território cotidiano.}

No âmbito dessa pesquisa não nos interessa somente a experiência habitacional imediatamente anterior à transferência para o Conjunto Habitacional Parque Continental. Outros dois momentos desses acontecimentos também nos preocupam: o da transferência para o Mutirão e o Conjunto Habitacional, e o período posterior à essa transferência. Esse último mais importante para nós. Isto porque, a delimitação do nosso universo empírico permite compreender que uma vez realocada/transferida de áreas favelizadas, habitações subnormais, aluguéis, e outras situações de moradia do setor oeste da cidade de São Paulo, a população, agora residente naquilo que denominamos Conjunto Habitacional Parque Continental, "perdeu" as referências espaciais do território anteriormente habitado por ela, haja vista a maneira tão peculiar da disposição espacial das habitações em áreas favelizadas, por exemplo, e a proposta "normatizadora" das habitações em prédios de apartamentos (no caso das Operações Interligadas e do PROVER).

Porém, a combinação das permanências e das transformações dessas experiências não está isenta de análise, ao contrário, determina sobremaneira a vida cotidiana na área em questão. 
Iniciamos nossa reflexão pelo processo de "desterritorialização", uma vez que adiante, quando apresentarmos a interlocução entre os moradores do Conjunto Habitacional Parque Continental, ficará claro ao leitor que nosso ponto de partida considera o momento anterior à transferência dos moradores para a área do Conjunto. Após refletir sobre essa dinâmica, passamos então, a pensar na constituição de um território, (no âmbito dessa pesquisa toda a área que compõe o Conjunto Habitacional Parque Continental, foco de nossa análise), segundo podemos observar na Imagem 2 p. 22). Vejamos:

Rogério Haesbaert (2002) identifica os diferentes enfoques dados à noção de desteritorialização atualmente em curso: a)como domínio das redes, dos fluxos, da mobilidade, b)como perda de referências espaciais, c)como perda de poder expressa pelo enfraquecimento de território dos Estados-Nações, d)como "deslocalização" econômica e e) como fruto da crescente homogeneização cultural do planeta.

Das perspectivas da desterritorialização apresentadas pelo autor, chama sua atenção uma lacuna:

Não é de surpreender que, no amplo leque de dimensões com que o tema da desterritorialização é tratado, justamente a grande ausente é a concepção mais estritamente social da desterritorialização, ou seja, aquela que vincula desterritorialização e vida material sob condições de exclusão socioespacial26 (2004, p.33).

Não concordamos com a noção de exclusão socioespacial adotada pelo autor, para nós, a dinâmica aludida por ele trata-se de segregação socioespacial27. El próprio relativiza a noção de exclusão:

A exclusão aviltante ou as indusões extremamente precárias a que as relações capitalistas relegaram a maior parte da humanidade faz com que muitos, no lugar de partilharem múltiplos teritórios, vaguem em busca de um, o mais elementar território da sobrevivência cotidiana. (p.17) ${ }^{28}$.

O argumento da inclusão precária defendido pelo sociólogo José de Souza Martins é com o qual mais nos aproximamos, ou seja, a segregação socioespacial presente nas cidades submete os indivíduos à inclusão precária e marginal no sistema capitalista de produção que

\footnotetext{
${ }^{26} \mathrm{O}$ autor dedica parte de seu estudo a esse aspecto.

${ }^{27}$ Desenvolvemos em outro texto reflexões acerca dessas noções: JESUS, Patrícia M de. Produção do Espaço Urbano no Jardim Humberto Salvador, Presidente Prudente/SP: afastamento, exclusão ou segregação socioespacial? Presidente Prudente, 2005. Monografia (Bacharelado em Geografia) - FCT/UNESP. Nesse momento, no entanto, não o faremos.

28 Grifo nosso.
} 
rege a sociedade contemporânea. E as políticas habitacionais examinadas por nós são então, a materialidade do "elementar território da sobrevivência cotidiana".

Cumpre assinalar ainda que parece nos adequado que o conjunto de moradores da área em questão passou ao longo da vida por várias experiências espaciais, em uma constante mobilidade. Porém, o primeiro momento (exatamente anterior à chegada ao Conjunto Habitacional) é o nosso ponto de partida.

Enfatizamos, entretanto, que não tratamos de uma dinâmica de migração, visto que essa noção nos remete ao deslocamento de um ou mais indivíduos de um país para outro ou de um Estado para outro dentro do mesmo país. Dessa forma, como se referir às pessoas quando analisamos o espaço intra-urbano da metrópole? Como definir as implicações da mobilidade intra-urbana daquele que muda de Itaquera para Santo Amaro? Ou de um fragmento para outro dentro de um mesmo distrito? No último caso ainda que no mesmo distrito, a forma de morar pode alterar completamente as relações com o espaço habitado, com as pessoas, com o próprio bairro. Eis a nossa busca.

Sobre as relações entre desterritorialização e mobilidade Haesbaert se pronuncia e indaga: "Em que sentido, podemos dizer que as migrações são também processos de desterritorialização?'

Se até mesmo o nomadismo, em que a centralidade do movimento e do "trajeto" é muito maior, representando ao mesmo tempo o núcleo de sua reprodução econômica e de sua expressão cultural, constrói um território (no movimento), a migração em sentido estrito, onde a mobilidade é mais um meio do que um fim, uma espécie de intermediação numa vida em busca de certa estabilidade (em sentido amplo), certamente não poderá ser vista simplesmente como um processo de "desterritorialização" (p.245)29.

Ou seja, se até o nômade, sempre em movimento constrói um território, o migrante ${ }^{30}$ não pode ser visto como desterritorializado, já que sua mudança, seu movimento quer buscar, ou procura certa estabilidade. Significa dizer ainda que desterritorialização não quer dizer necessariamente movimento, e também o contrário é verdadeiro, isto é, nem sempre estabilidade ou pouca mobilidade implicam em territorialização.

Diante da complexidade dessas dinâmicas (desterritorialização e migração), é interessante relativizar qualquer análise em detrimento de absolutizar o impossível. Em virtude da atualidade do debate, não temos ainda elementos que dêem sustentação à

${ }^{29}$ Grifos do autor.

30 Ainda que não tenhamos dados que corroborem nossa afirmação, é certo que dentre os chefes de família da população constituinte do Conjunto Habitacional Parque Continental há migrantes. 
desterritorialização como perda de referências espaciais e a concepção social de desterritorialização, não no âmbito da escala de análise dessa investigação que é estritamente intra-urbana.

Nesse contexto partimos para nossa definição de território, pois, consideramos a área objeto de nossa pesquisa mais que constitutiva do espaço geográfico, um território.A seguir as formulações que corroboram nossa intenção.

Não iremos adentrar no debate sobre todas as dimensões acerca do território. Valemosnos da síntese elaborada pelo referido autor, para então, apresentar as formulações que melhor nos auxiliam.

$\checkmark$ Política - (referida às relações espaço-poder em geral) ou jurídico-política (relativa também a todas as relações espaço-poder institucionalizadas): a mais difundida, onde o território é visto como um espaço delimitado e controlado, através do qual se exerce um determinado poder, na maioria das vezes - mas não exclusivamente - relacionado ao poder político do Estado.

$\checkmark$ Cultural - (muitas vezes culturalista) ou simbólico-cultural prioriza a dimensão simbólica e mais subjetiva, em que o território é visto, sobretudo, como o produto da apropriação/valorização simbólica de um grupo em relação ao seu espaço vivido.

$\checkmark$ Econômica - (muitas vezes economicista): menos difundida, enfatiza a dimensão espacial das relações econômicas, o território como fonte de recursos e/ou incorporado no embate entre classes sociais e na relação capital-trabalho, como produto da divisão "territorial" do trabalho, por exemplo.

$\checkmark$ Naturalista - Noção de território com base nas relações entre sociedade e natureza, especialmente no que se refere ao comportamento "natural" dos homens em relação ao seu ambiente físico. (p.40) ${ }^{31}$.

Das perspectivas apresentadas, aquela com a qual mais nos aproximamos é a dimensão cultural-simbólica do território. Ainda que numa visão integradora, pode-se apreender um território em uma ou mais dessas perspectivas. Nosso recorte territorial, por exemplo, ainda que resposta de demandas populares é também e inclusive "um espaço delimitado e controlado, através do qual se exerce um determinado poder, na maioria das vezes - mas não

${ }^{31}$ Grifos do autor. 
exclusivamente - relacionado ao poder político do Estado". No caso do poder político do Estado, (representado pela Prefeitura Municipal) a situação fundiária irregular das unidades habitacionais do empreendimento confere alto grau de insegurança aos moradores no que se refere à propriedade de suas casas. Ainda em relação ao nosso recorte territorial, (numa escala muito menor) pode-se entender o "território como fonte de recursos", ou seja, numa concepção econômica.

Vejamos a contribuição de Raffestin (1993) ${ }^{32}$, relacionando espaço e território em que percebemos aspectos da perspectiva simbólica-cultural deste, mas também de sua dimensão política. Para ele território e espaço não são termos equivalentes. Espaço é anterior ao território. Ao se apropriar de um espaço concreta ou abstratamente (por exemplo, pela representação), o agente "territorializa" esse espaço. O território é um espaço onde se projetou um trabalho, seja energia e informação, e que, por conseqüência, revela relações marcadas pelo poder. (p.143).

Nesse sentido território é uma produção a partir do espaço (entendido como condição, produto e meio). O que nos remete a formulação de território usado de M Santos, "o território usado constitui-se como um todo complexo onde se tece uma trama de relações complementares e conflitantes33. Daí o vigor do conceito, convidando a pensar processualmente as relações estabelecidas entre o lugar, a formação socioespacial e o mundo". (2000, p.3).

Ainda em relação ao território usado, distinguindo-o como recurso e como abrigo, Santos (op.cit) afirma que, enquanto;

"para os atores hegemônicos o território usado é um recurso, garantia de realização de seus interesses particulares", para os "atores hegemonizados" trata-se de um "abrigo, buscando constantemente se adaptar ao meio geográfico local, ao mesmo tempo em que recriam estratégias que garantam sua sobrevivência nos lugares". (p.13).

Para nossa investigação podemos interpretar os atores hegemônicos como o poder público municipal e as parcerias com a iniciativa privada ${ }^{34}$ e os atores hegemonizados, os moradores. No entanto, no que diz respeito ao Programa de Mutirão e Autogestão, a postura do Poder Público Municipal mediante as demandas populares foi justamente uma tentativa de

32 Original de 1980.

${ }_{33}$ Grifo nosso.

${ }^{34}$ Deteremos mais atenção sobre esse aspecto adiante, no entanto, lembramos aqui as parcerias entre a administração Luiza Erundina e as Assessorias Técnicas de Arquitetura e Engenharia e entre a administração de Paulo Maluf e bancos internacionais de financiamento e entre as duas e as empreiteiras. 
contrariar essa relação, conferindo aos futuros moradores a possibilidade de serem sujeitos de sua própria ação.

Contrapondo ordem global e ordem local35, o mesmo autor apresenta relações dessas "estruturações do real" ao processo de desterritorialização e ao de reterritorialização e, este último, ao cotidiano. Vejamos:

A ordem global funda as escalas superiores ou externas à escala do cotidiano. Seus parâmetros são a razão técnica e operacional, o cálculo de função, a linguagem matemática. A ordem local funda a escala do cotidiano e seus parâmetros são a copresença, a vizinhança, a intimidade, a emoção, a cooperação e a socialização com base na contigüidade. A ordem global é "desterritorializada", no sentido de que separa o centro da ação e a sede da ação. (...) A ordem local, que "reterritorializa", é a do espaço banal, espaço irredutível porque reúne numa mesma lógica interna todos os seus elementos ${ }^{36}$ : homens, empresas, instituições, formas sociais e jurídicas e formas geográficas. O cotidiano imediato, localmente vivido, traço de união de todos esses dados, é a garantia da comunicação ${ }^{37}$.

Assim inferimos que comunicação está para a ordem local; como informação para ordem global.

Para Haesbaert (2002), o território se compõe de forma indissociável à reprodução dos grupos sociais, no sentido de que as relações sociais são espacial ou geograficamente mediadas. Desse modo, entendemos o território como o lugar de exercício da cidadania, onde se concretizam as relações sociais, as relações de solidariedade e vizinhança, onde existem relações de identidade, e também relações de poder ${ }^{38}$.

Numa perspectiva simbólico-cultural (Bonnemaison \& Cambrèzy apud Haesbaert 2004) consideram que:

A lógica territorial cartesiana moderna dá pouca ênfase aos fluxos, ao movimento, e é suplantada hoje pela "lógica culturalista, ou se preferirmos (pós-modema), que a geometria não permite medir e a cartografia, menos ainda, representar. Nesta (...) perspectiva o pertencimento ao território implica a representação da identidade cultural e não mais a posição num polígono. Ela supõe redes múltiplas, refere-se à geossímbolos mais que a fronteiras, inscreve-se nos lugares e caminhos que ultrapassam os blocos de espaço homogêneo e contínuo da 'ideologia geográfica'”."

\footnotetext{
${ }^{35}$ Essas duas ordens constituem duas situações geneticamente opostas, ainda que em cada uma se verifiquem aspectos da outra.

36 Sobre os elementos do espaço, ver Santos, M. Espaço e Método. 3ª edição. São Paulo: Nobel, 1992.

37 Grifos do autor. (1996, p.236).

${ }^{38}$ Como é sabido, 0 autor que melhor relaciona território e os fundamentos materiais do Estado é o geógrafo alemão

F. Ratzel.
} 
Inferimos da citação que são, portanto, as relações entre as pessoas e das pessoas com o espaço habitado constituinte de seus territórios que empreendem identidade e pertencimento aos lugares 39 .

Nesse sentido, para nós território é um espaço de referência para a construção de identidades. O. Seabra (2004) explora a idéia de que o cotidiano não pode passar sem espaços e tempos apropriados, sem "territórios do uso". Para ela são os fundamentos desiguais desta sociedade que explicam a própria espacialidade desses territórios, "sejam quarteirões bem equipados com alto valor imobiliário ou as áreas precariamente urbanizadas". São as contradições da sociedade que impõem, no âmbito do vivido, estratégias e lutas à sobrevivência no urbano porque, para permanecer habitante há que ser morador, há que ser aquele que usa, que delimita territórios de uso. (p.183 e outras).

Em sua perspectiva, territórios de uso correspondem ao espaço de morar, quer sejam condomínios residenciais fechados ou conjuntos habitacionais, dentre outras configurações no urbano, reflexos da segregação socioespacial consumada.

Para nosso fim, arriscamos a denominação de territórios do cotidiano. Vamos à constituição destes, não sem antes verificar brevemente as políticas habitacionais municipais anteriores às políticas objetos de nossa análise: Programa de Mutirão e Autogestão e Programa de Verticalização e Urbanização de Favelas.

1.5 Políticas Habitacionais em São Paulo: Antecedentes.

É comum na literatura especializada o tratamento desse tema a partir da Ditadura Militar (1964 a 1985) e do BNH (Banco Nacional de Habitação), tratado como a primeira política habitacional estruturada em nível federal no país. Esses estudos tomam esse período como referência para empreender análises das tentativas do Estado para mitigar o déficit habitacional no país ${ }^{40}$.

\footnotetext{
${ }^{39}$ Embora não seja uma simples questão de mudança de escala, também há uma revalorização da dimensão local. O território reforça sua dimensão enquanto representação, valor simbólico (op.cit; p.71).

${ }^{40}$ Chamamos atenção para a análise de Bonduki (1998) que desvenda as origens da habitação social no país em período exatamente anterior à Ditadura Militar com a criação dos Institutos de Aposentadoria e Pensões (IAPI) e Fundação da Casa Popular. Importante destacar que na década de 1940 no governo de Getúlio Vargas a habitação social era entendida como um senviço público e não somente como propriedade individual da habitação. Desse modo, o conceito previa também a implementação nos conjuntos habitacionais de equipamentos coletivos. Para esse autor "a década de 1940 é crucial, no que se refere à ação do Estado no setor habitacional, quando ocorrem as primeiras intervençães do governo federal - congelamento dos aluguéis, produção em massa de moradias por intermédio dos IAPs e criação da Fundação da Casa Popular" (p.209)
} 
Para Gonçalves (1998) o déficit habitacional brasileiro é de 5.083 .320 unidades habitacionais, no Estado de São Paulo o déficit corresponde a 799.965 unidades habitacionais. Contudo, o autor alerta para as mais diferentes metodologias utilizadas para o cálculo do déficit habitacional no país. Segundo ele, considerando essas metodologias, o déficit habitacional pode variar de 4 até 40 milhões de unidades, dependendo da amplitude do critério adotado. Para seu estudo, o déficit habitacional brasileiro é avaliado a partir de três elementos:

$\checkmark$ A rusticidade das estruturas físicas das habitações, em virtude da depreciação e/ou da utilização de materiais improvisados ou não-duráveis.

$\checkmark$ A inadequação de algumas unidades habitacionais, que em decorrência de suas características físicas e funcionais, são utilizadas como domicílios de forma esporádica ou improvisada.

$\checkmark$ A coabitação (existência de mais de uma família por domicílio em média).

O fim do BNH em 198641 recolocou a questão da habitação popular em pauta e na promulgação da Constituição de 1988 a autonomia dos municípios na promoção de habitação foi destacada (ainda que as municipalidades continuassem atreladas aos escassos repasses dos governos estadual e federal).

Para Marques \& Saraiva (2005)

ao longo do tempo, entretanto, a pressão dos movimentos sociais e o declínio financeiro e operacional do $\mathrm{BNH}($...)influenciaram o desenvolvimento e a consolidação de vários tipos de política alternativa, implementados principalmente por governos municipais, o que chegou a alterar a estrutura dos gastos nacionais em habitação (p.271).

Do exposto acima, ressaltamos que não analisaremos as políticas de habitação do longo período empreendido desde o período militar42 até a década de 2000. Compete ao nosso entendimento as políticas municipais de habitação implementadas no período de 1989 à 2000 , que coincide com três administrações municipais: Luiza Erundina, à época filiada ao PT(1989 -

${ }^{41}$ Baseado em literatura sobre o tema Silva (2003) elenca os motivos pelos quais o Banco Nacional da Habitação foi extinto: "a não coincidência entre os reajustes das prestações e os reajustes salariais dos mutuários; a tentativa de sanar o problema anterior indexando os reajustes de prestações aos reajustes salariais no momento em que os salários sofriam grande perda do poder real de compra; correção das prestaçães dos imóveis abaixo das correçães salariais; desvio de recursos destinados à construção de habitaçães para instalação de infra-estrutura urbana que não apresentavam retorno financeiro para o Sistema Financeiro de Habitação". (p.16)

${ }^{42} \mathrm{~A}$ bibliografia sobre esse tema é ampla, todavia remetemos o leitor a alguns trabalhos: AZEVEDO,S \& ANDRADE, L. Habitação e poder: da fundação da casa popular ao Banco Nacional da Habitação. Rio de Janeiro: Zahar, 1981; MARICATO, Ermínia. Política habitacional no regime militar. Petrópolis: Editora Vozes, 1987;BONDUKI, Nabil. Origens da habitação social no Brasil: arquitetura moderna, Lei do Inquilinato e difusão da casa própria. São Paulo: Estação Liberdade, 1998; SACHS, Céline. São Paulo: Políticas Públicas e Habitação Popular. São Paulo: Edusp, 1999. 
1992), Paulo Maluf, à época filiado ao PPB (1993-1996) e Celso Pitta, à época filiado também ao PPB (1997-2000). E não poderia ser diferente, pois, a área em questão para essa investigação é fruto dessas políticas.

No que respeita a políticas alternativas no setor de habitação, a gestão de Luiza Erundina merece destaque conforme veremos adiante.

Conforme salientamos, abordaremos as políticas habitacionais implementadas no período compreendido entre os anos de 1989 - 2000, com destaque para três intervenções dessas políticas: Mutirões autoconstruídos e autogeridos, Operações Interligadas e o Programa de Verticalização e Urbanização de Favelas.

Antes, porém, cumpre apresentar, ainda que sucintamente, o panorama das políticas municipais em período que antecede as políticas alvo de nossa investigação, a fim de contextualizá-las.

De acordo com Marques \& Saraiva (op. cit)

As políticas habitacionais adotadas até meados da década de 1980 estavam praticamente restritas às desenhadas a partir do sistema gerido pelo Banco Nacional da Habitação (BNH). A partir de então, a participação dos municípios como promotores da habitação ganhou destaque, e, em 1988, a Constituição Brasileira, em seu Capítulo II, Artigo 23, consagrou como de competência comumà União, aos estados e aos municípios promover programas de construção de moradias, de melhoria das condições habitacionais e de saneamento básico. (p.267).

Bonduki indica a criação do FUNAPS (Fundo de Atendimento à População Moradora em Habitações Subnormais) em 1979 como o início da atuação da Prefeitura Municipal no que tange ao problema habitacional.

Esse fundo recebeu recursos do orçamento municipal para aplicação a fundo perdido no atendimento a famílias de renda baixa. Essa ação também foi limitada até 1989, seja pela insuficiência de recursos disponíveis, pela falta de estrutura administrativa e técnica, ou pela ausência de uma estratégia para equacionar o problema em toda a sua complexidade. (1996 p.180)

De acordo com o mesmo autor, em meados de 1970, a solução tradicional da compra de lotes clandestinos e periféricos para o auto-empreendimento da casa própria tornou-se inviável para a população. Dessa maneira, ao longo da década de 1980 cresceu a reivindicação por terra, habitação, creche e outras melhorias em São Paulo. (idem). Eram os "novos personagens em cena"43 analisados por Eder Sader.

${ }^{43}$ Segmentos da Igreja Católica, profissionais liberais e suas associações, sindicatos e outras entidades civis. 
Na esteira desse processo e como resposta aos problemas apresentados pelo sistema, no final da década de 1980, o BNH foi incorporado à Caixa Econômica Federal sem encaminhar nenhuma solução para o rombo financeiro que a política habitacional brasileira acumulou durante vinte anos. Esta atitude representou a substituição de um banco de fomento por um banco comercial. O resultado foi um processo de maior elitização do público atendido pelos programas de construção e compra de imóveis ou de materiais para construção e, conseqüentemente, a diminuição da oferta de imóveis novos e aumento de seu valor no mercado. O que impedia sobremaneira a população de menor renda a acessar esse bem.

A promoção de habitação popular passa então a ser competência do município de acordo com a nova Constituição de 1988 e para tanto, houve uma reestruturação da burocracia paulistana para fazer cumprir esse dever.

É nesse contexto que em 1989 Luiza Erundina é eleita prefeita da cidade de São Paulo. E partimos dessa breve reflexão para apresentar a política habitacional implementada no interior de sua administração.

1.6 A política de provisão de habit ação na administração Luiza Erundina.

A administração de Luiza Erundina apresentou características bastante específicas do executivo paulistano em fins da década de 1980, que a diferenciaram dos prefeitos anteriores; por pelo menos alguns motivos: mulher, migrante nordestina, e militante junto aos movimentos sociais urbanos. Sua ação política no que se refere à promoção de habitação de interesse social no município destacou sobremaneira seu governo na metrópole paulistana.

Mediante o período de crise no setor que antecedeu o seu governo e a proximidade da referida prefeita aos problemas de moradia da população paulistana, a habitação popular foi a "menina dos olhos" de sua gestão.

No que diz respeito à captação de recursos, além da aprovação na Assembléia Legislativa Estadual do direcionamento de 1\% do ICMS para o financiamento de habitações populares, a municipalidade criou novas fontes de recursos gerados por processos de produções imobiliárias privadas. A Lei de Desfavelamento é exemplo disso, pois permitia às empreiteiras conseguirem lucros sem respeitar a Lei de Zoneamento da cidade, e em contrapartida, viabilizava condições financeiras para a Prefeitura remover favelas de áreas nobres da cidade. Posteriormente, essa lei passou a ser denominada como Lei das Operações Interligadas que 
legitimava as alterações no zoneamento do município beneficiando os agentes construtores privados e esses, por sua vez, viabilizavam recursos para produção de habitações populares como contrapartida. Esse instrumento foi a principal fonte de recursos destinada ao FUNAPS (Fundo de Atendimento à População Moradora em Habitações Subnormais), órgão administrado pela Secretaria de Habitação.

Segundo Marques \& Saraiva esse fundo

criado no governo Olavo Setúbal em resposta à crescente pressão dos movimentos de habitação, durante vários anos financiou principalmente remoções de favela, obras pontuais e atendimento a famílias em situação de risco. Apenas no governo Mário Covas o fundo passou a financiar iniciativas de atendimento mais amplo e duradouro. (p.276).

Todavia, sabe-se que no governo Mário Covas, as políticas desse setor concentraram-se na construção por empreiteiras de unidades novas em grandes conjuntos habitacionais da periferia pela COHAB, uma vez que o decreto 26.913 de Jânio Quadros estabelecia que a contrapartida recolhida pelo FUNAPS deveria ser empregada somente em construção de habitação popular por empreiteira.

Com o intuito de dar outro direcionamento aos recursos, Luiza Erundina tenta aprovar o Projeto de Lei 200/89, que propunha a utilização daqueles expedientes em aquisição de terrenos, intervenção em cortiços, urbanização de favelas e projetos de produção habitacional pelo sistema de mutirão. (Silva, 2003)

Não obtendo êxito nas tramitações legais, Luiza Erundina decide dar outro sentido para o termo desfavelamento, para conseguir, dessa forma, usar o recurso do FUNAPS via Operações Interligadas. Desfavelamento entendido como remoção da população favelada das regiões nobres da cidade passou a ser entendido então, como: 1)Transformar favelas densamente povoadas e localizadas em áreas valorizadas em conjuntos habitacionais, 2) Reurbanizar favelas grandes e populosas através da remoção de parte dos habitantes para áreas próximas, como conjuntos habitacionais ou lotes ainda por legalizar, a fim de permitir a abertura das vias no interior das favelas, 3)Desfavelamento e remoção de moradias subnormais localizadas em áreas de risco.

Certa da resistência da oposição conservadora, a prefeita faz via decreto a oficialização da política de promoção de moradias populares de seu governo. Com isso, cria os conselhos de habitação popular no município, garantindo participação de diversos segmentos da sociedade em sua composição: representantes de associações de moradores, senvidores públicos, entre 
outros. O objetivo era normatizar, formular, e promover os programas habitacionais de interesse social. (idem)

Nabil Bonduki (1995) elenca uma série de diretrizes e princípios característicos da nova postura daquela administração que pretendia se tornar referência num processo de renovação da Política Nacional de Habitação. Para nossa análise interessam principalmente:

$\checkmark$ Diversidade de programas e projetos, rompendo a uniformidade de soluções que caracterizaram o período $\mathrm{BNH}$,

$\checkmark$ Direito à cidadania, garantindo a participação popular na formulação de projetos e programas, na definição da demanda dos empreendimentos e nas prioridades orçamentárias,

$\checkmark$ Direito de morar com dignidade no centro urbano e áreas de urbanização consolidada, rompendo a lógica da segregação urbana que destina apenas as zonas periféricas para a população de baixa renda. (p.182).

A partir desses e outros pressupostos, foram criados vários programas habitacionais para enfrentar as diferentes manifestações da carência de moradia em São Paulo. São exemplos: Programa de Desapropriação de Terras, Programa de Urbanização e Regularização Fundiária em Favelas, o Programa de Verticalização de Favelas (posteriormente conhecido como Gingapura), o Programa de Intervenção em Habitações Coletivas, Programa de Prevenção à Mbradia em Área de Risco e o Programa de Produção de Unidades Habitacionais em Mutirão e Autogestão. (Bonduki, 1993,1996).

Dentre todos esses programas, pela quantidade dos empreendimentos, pela participação popular, por seus aspectos negativos e positivos, o Programa de Produção de Unidades Habitacionais em Mutirão e Autogestão foi aquele que mais se destacou na referida gestão.

1.7 Construir e autogerir mutirões.

O Programa de Produção de Habitação em Mutirão e Autogestão foi desenvolvido pela equipe da Superintendência de Habitação e Desenvolvimento Urbano da Prefeitura de São Paulo (1989 - 1992). Participaram desse processo três agentes: 1)O poder público, no caso, a Prefeitura que definia as regras de implantação e financiava os empreendimentos através do FUNAPS (Fundo de Atendimento à População Moradora em Habitações Subnormais); 2)As 
Associações Comunitárias, formadas exclusivamente por todos os futuros moradores, que promoviam e administravam o empreendimento; e 3)Entidades de Assessoria Técnica (principalmente escritórios de engenharia e arquitetura), que elaboravam os projetos e assessoravam o trabalho de construção em mutirão.

Do ponto de vista das diretrizes e do uso do financiamento, vejamos o que nos diz Bonduki (1996):

Nas diretrizes do programa estabeleceram-se os limites de financiamento (até 7 mil dólares por unidade e 110 dólares por metro²), as regras para a utilização dos recursos e a prestação de contas, a documentação necessária para a aprovação do convênio, os mecanismos para a liberação das parcelas e os instrumentos de medição de obras etc. Pelo convênio, cabe a essas entidades gerir todo o processo produtivo de construção das unidades habitacionais. Assim, devem contratar entidade de assessoria técnica, utilizando até $4 \%$ do financiamento, montar o canteiro de obras, adquirir os equipamentos e ferramentas de trabalho, comprar o material de construção, organizar o mutirão, envolvendo todos os futuros moradores, e contratar, até o limite de $10 \%$ do total do financiamento, parte da mão-de-obra especializada. No mínimo $82 \%$ dos recursos devem ser utilizados na compra de material de construção. (...) O projeto, a escolha do material de construção e a definição da demanda, devem ser discutidos e aprovados em assembléia pelos mutirantes, (...). Cabe à prefeitura analisar os projetos e a documentação apresentada para aprovar o financiamento, fiscalizar o andamento das obras e realizar as medições, para liberar novas parcelas do financiamento, assim como avaliar as prestações de contas dos recursos utilizados. A prefeitura se responsabiliza também pela desapropriação do terreno e pela implantação da infraestrutura. (p.183)

Podemos inferir a partir disso, que não se tratava apenas da construção das unidades através da utilização de mão-obra gratuita dos mutirantes, como outrora ocorreu na incipiente experiência de mutirão por Mário Covas ${ }^{44}$. Tratava-se também, e inclusive, da gestão do empreendimento pelos próprios mutirantes. Essa foi a principal inovação da administração de Luiza Erundina. Entretanto, se por um lado o processo construtivo em mutirão conferiu envolvimento dos futuros moradores, por outro lado, a experiência da autogestão gerou uma série de conflitos no interior dos mutirões.

Quanto aos números do programa, não há exatidão dos dados nas fontes consultadas: para Bonduki (1995) o número de moradias construídas em processo de mutirão foi de 11.000 unidades habitacionais, Ronconi apud Felipe (1995) trabalha com a cifra de 12.531 unidades habitacionais, Marques \& Saraiva (2005) apresentam dados de 12.351 unidades habitacionais e o Relatório da SEHAB - HABI (2000) apresenta o montante de 13.913 unidades habitacionais. Tal inexatidão pode consistir no fato de que quando não houve a possibilidade da produção das

${ }^{44}$ Ver BISILLIAT-GARDET, Jeanne. Mutirão - Utopia e necessidade. CNPq - ORSTOM. Sem data. 
unidades por mutirão em virtude das peculiaridades do meio físico, as construções foram feitas por empreiteiras, o que pode justificar a diferença quanto aos números. Outro motivo pode ser a soma não só dos empreendimentos construídos, mas também daqueles em obras ou em projetos à época em que as referidas obras foram publicadas.

No entanto, a única fonte consultada em que tivemos acesso aos dados desmembrados por empreendimento foi o relatório da SEHAB-HABI. Julgamos interessante reproduzir e reorganizar os dados para examinar a espacialização desses empreendimentos no município de São Paulo, como podemos notar no mapa 1 (p.43), bem como para termos a noção da dimensão dos empreendimentos, em que pese a opção por parte da equipe técnica da Prefeitura por empreendimentos de pequeno porte, conforme mostra o quadro 1 (p.37).

A observação do mapa revela a concentração de empreendimentos na extremidade da porção leste do município, sobretudo nos distritos de Itaim Paulista, Lajeado, Guaianazes, Cidade Tiradentes, e São Rafael. No distrito de São Rafael, localiza-se o empreendimento São Francisco, uma das primeiras experiências de mutirão no município de São Paulo. Construído em várias fases, soma mais de 1.000 unidades habitacionais (cf quadro 1). Interessante ressaltar ainda que há na porção leste da cidade (em virtude certamente de mais "terras disponíveis" que em outras porções da mesma, como por exemplo, a zona sul limitada pelos Reservatórios Billings e Guarapiranga, e a zona norte limitada pelo Parque Estadual da Serra da Cantareira) outras intervenções resultantes de programas e/ou políticas públicos de habitação: os gigantes empreendimentos implantados pela COHAB, edifícios do PROVER, urbanização de favelas, programas habitacionais construídos pela $\mathrm{CDHU}$, regularização urbanística fundiária, urbanização e regularização de loteamentos, planos de ação-convênio BIRD/Cities Alliance. (SEHAB/HABI, 2000; Miazuko, 2007)45.

Há na porção sudoeste também uma concentração de empreendimentos construídos por mutirão e autogestão, fundamentalmente nos distritos de Campo Limpo, Capão Redondo, e Jardim São Luís. Nos distritos de Socorro, Cidade Dutra e Grajaú, há também empreendimentos desse Programa, contudo, cumpre salientar a proximidade dos empreendimentos com os Reservatórios Billings e Guarapiranga. Na porção norte do município, os distritos em que há mais ocorrências de Mutirões construídos através de autogestão são Jaraguá, Brasilândia, e Jaçanã.

${ }^{45}$ Numa sobreposição possível dos Mapas 1(p.41) e 2 (p.77) o leitor notará a "coincidência" de algumas áreas onde foram implementados os Programas de Construção de Unidades Habitacionais em Mutirão e Autogestão e a posterior implantação do Programa de Verticalização e Urbanização de Favelas. É o caso, por exemplo, dos distritos Jaguaré (Estrela Guia), Jaraguá (Mbvimento Unido), Ipiranga (Haia do Carrão e Heliópolis), São Rafael (São Francisco). Para essas áreas (em que há uma concentração de mais de um programa habitacional) a equipe técnica da HABI/SEHAB dá o nome de "área pulmão". 
Nas proximidades do centro antigo do município, as maiores ocorrências estão no distrito do Ipiranga, onde está situada a favela de Heliópolis e ocorrências pontuais como é o caso da Moóca, Belém, Vila Prudente, Brás. Na porção oeste do município, experiências também pontuais como é o caso do Jaguaré (parte de nosso objeto de estudo), Rio Pequeno e Raposo Tavares. Essas ocorrências "pontuais" denotam também a preocupação da Administração Municipal de implementar empreendimentos que não apresentassem a monotonia dos grandes conjuntos habitacionais, como é o caso dos conjuntos habitacionais implementados pela COHAB localizados na porção leste do município.

A partir de alguns princípios gerais onde se tinha claro que um certo pedaço da cidade não se pode separar do restante, ou de que o respeito aos moradores passava pela manutenção de seus modos de morar, no lugar de se procurar segregá-los, ou mesmo destrú-los com vultuosas cirurgias urbanas (...)o que se visou foi atribuir às formas arquitetônicas o meio de diferenciar territórios peculiares, marcando cada situação habitacional com uma arquitetura específica. (Bonduki, 1993, p.15)

A citação acima corrobora as diversas desapropriações de terra no município para a construção dos mutirões. A idéia era aproveitar os "vazios urbanos" já existentes, e não criar novos "vazios" a partir da construção de conjuntos habitacionais em distantes áreas periféricas, como fizeram outras administrações municipais.

Cumpre assinalar que, se cada empreendimento de mutirão tinha um projeto arquitetônico diferente, isso não conferiu associação entre essa política habitacional e a administração municipal que a implantou. O mesmo não se pode dizer de outras políticas da cidade, como é o caso dos conjuntos habitacionais implementados pela COHAB associados a outros administradores do município e os empreendimentos Cingapura associados a Paulo Maluf e Celso Pitta, justamente pela uniformidade do desenho arquitetônico dos empreendimentos em toda a cidade. No caso do PROVER (popularmente conhecido como Cingapura) a associação entre as políticas habitacionais e os políticos que a implantaram também é resultado da localização dos empreendimentos na malha urbana da cidade, como podemos verificar no mapa 2 (p.77) e como melhor discutiremos mais adiante.

Do exposto até aqui, temos subsídios para nesse momento direcionar nossa atenção para investigar mais detidamente o caso do Mutirão Estrela Guia, parcela do que denominamos Conjunto Habitacional Parque Continental. $\mathrm{O}$ croqui à página 42, nos dá a noção da área à época da implantação do Mutirão. 
QUADRO 1: PROGRAMA DE PRODUÇÃO ONSTRUÇÃO DE UNIDADES HABITACIONAIS EM MUTIRÃO E AUTOGESTÃO NO MUNICÍPIO DE SÃO PAULO

\begin{tabular}{|c|c|c|}
\hline EMPREENDIMENTO & $\begin{array}{l}\text { DISTRITOS } \\
\text { MUNICIPASS }\end{array}$ & $\begin{array}{c}\text { UNIDADES } \\
\text { HABITACIONAIS }\end{array}$ \\
\hline Lapena & Brás & 176 (2 setores) \\
\hline Estrela Guia & Jaguaré & 100 \\
\hline Morada do Sol I e II & Anhanguera & 313 \\
\hline Por do Sol/ Jardim Brasília & Brasilândia & 160 \\
\hline Projeto União (Tiro ao Pombo) & Freguesia do 0 & 40 \\
\hline $\begin{array}{l}\text { Recanto das Estrelas } \\
\text { (Jardim Brasília) }\end{array}$ & Brasilândia & 153 \\
\hline $\begin{array}{c}\text { Vila Nova Cachoeirinha - } \\
\text { Fases I e II }\end{array}$ & Brasilândia & 206 \\
\hline Vista Alegre (F.N.T) & Brasilândia & 20 \\
\hline Rem. da Liberdade (SONDA) & Vila Medeiros & 125 \\
\hline Santo Dias/ Vila Nilo & Jaçanã & 200 \\
\hline Condomínio Paraíso & Jaraguá & 60 \\
\hline Jardim Paquetá & Freguesia do Ó & 166 \\
\hline Movimento Unido & Jaraguá & 164 \\
\hline Pedra Bonita & Jaraguá & 172 \\
\hline Portal São Marcos & Jaraguá & 104 \\
\hline Quero Um Teto I,II e III & Brasilândia & 108 \\
\hline Santa Marta & Jaraguá & 72 \\
\hline Vista Linda & Jaraguá & 131 \\
\hline Chico Mendes (Apuanã) & Jaçanã & 200 \\
\hline João de Barro (Apuanã) & Jaçanã & 200 \\
\hline Junto Venceremos (Apuanã) & Jaçanã & 200 \\
\hline
\end{tabular}




\begin{tabular}{|c|c|c|}
\hline União do Povo (Apuanã) & Jaçanã & 200 \\
\hline Área Treze & Guaianazes & 152 \\
\hline Baltazar Cisneiro & Lajeado & 200 \\
\hline Barro Branco I & Cidade Tiradentes & 100 (2 etapas) \\
\hline Barro Branco II & Cidade Tiradentes & 100 (2 etapas) \\
\hline Barro Branco III & Cidade Tiradentes & 100 (2 etapas) \\
\hline Barro Branco IV & Cidade Tiradentes & 100 (2 etapas) \\
\hline Campanha Gaúcha & Lajeado & 128 \\
\hline Casa Blanca/Petrilli & Guaianazes & 200 \\
\hline $\begin{array}{l}\text { Clube de Mães Vila Simone (Miguel } \\
\text { Ackel) }\end{array}$ & Lajeado & 124 \\
\hline CONSABS (Miguel Ackel) & Lajeado & 200 \\
\hline Jardim leda (Miguel Ackel) & Lajeado & 20 \\
\hline $\begin{array}{l}\text { Parque das Andorinhas(Baltazar } \\
\text { Cisneiro) }\end{array}$ & Lajeado & 115 \\
\hline Pires do Rio & Itaquera & 37 \\
\hline Terra de Todos/ Terra de Deus & Guaianazes & 150 \\
\hline $\begin{array}{l}\text { União Popular Vila Simone (Miguel } \\
\qquad \text { Ackel) }\end{array}$ & Lajeado & 126 \\
\hline Barro Branco V (Vida Nova) & Cidade Tiradentes & 100 (2 etapas) \\
\hline Winnie Mandela & Cidade Tiradentes & 200 \\
\hline Boa Esperança (Texima) & Itaim Paulista & 200 \\
\hline Jardim Miriam III & Itaim Paulista & 100 \\
\hline Lírios do Itaim/ Chácara das Flores & Itaim Paulista & 206 \\
\hline Rio das Pedras I e II (Vila Mara) & Itaim Paulista & 288 \\
\hline Rio das Pedras II (Vila Mara) & Itaim Paulista & 144 \\
\hline Vila Mara I e II & Itaim Paulista & 288 \\
\hline Boa Esperança & Iguatemi & 106 \\
\hline Complexo Vergueirinho & São Mateus & 389 \\
\hline Dois de Maio & São Mateus & 58 \\
\hline São Francisco 5 - B (MDF) & São Rafael & 170 \\
\hline São Francisco 8 (SUDESTE) & São Rafael & 152 \\
\hline São Francisco I, II, III, IV, V & São Rafael & 808 \\
\hline
\end{tabular}




\begin{tabular}{|c|c|c|}
\hline XV de Novembro de 1988 & São Rafael & 153 \\
\hline Vinte e Seis de Julho I,II,III (JUTA) & São Mateus & 561 \\
\hline Haia do Carrão & Aricanduva & 45 \\
\hline Heliópolis & Ipiranga & 13 \\
\hline Heliópolis/ Flor do Pinhal & Ipiranga & 369 \\
\hline Heliópolis/ São João Climaco & Ipiranga & 300 \\
\hline Heliópolis/ São Gregório & Ipiranga & 310 \\
\hline Jardim Celeste & Sacomã & 400 (2 etapas) \\
\hline Jardim Celeste / Mac & Sacomã & 46 \\
\hline Lagoa(Heliópolis) & Ipiranga & 27 \\
\hline Celso Garcia & Belém & 182 \\
\hline Madre de Deus & Mooca & 45 \\
\hline Vila Bela & Vila Prudente & 68 \\
\hline Vinte e três de outubro & Cidade Dutra & 107 \\
\hline Alto da Riviera & Capão Redondo & 27 \\
\hline Casa Branca/Monet & Campo Limpo & 56 \\
\hline Guarapiranga (Talara) & Jardim São Luís & 102 \\
\hline Jardim das Palmas (Talara) & Jardim São Luís & 102 \\
\hline Monte Azul & Jardim São Luís & 423 \\
\hline Residencial (Talara) & Jardim São Luís & 102 \\
\hline Santa Zélia & Cidade Ademar & 112 \\
\hline Santo e Mendes (Monet) & Campo Limpo & 56 \\
\hline Sônia Ingá (Fase II) & Capão Redondo & 200 \\
\hline Terra Nossa (Monet) & Campo Limpo & 56 \\
\hline Trabalho e Moradia (Talara) & Jardim São Luís & 102 \\
\hline União de Todos & Capão Redondo & 100 (2 etapas) \\
\hline União Força e Terra (Monet) & Campo Limpo & 57 \\
\hline Unidos Venceremos & Capão Redondo & 100 (2 etapas) \\
\hline Valo Velho II - Povo Em Ação & Capão Redondo & 212 \\
\hline Vila Nova Peinha - FUNACOM & Vila Andrade & 40 \\
\hline
\end{tabular}




\begin{tabular}{|c|c|c|}
\hline Vila Nova Peinha - URBANACOM & Jardim São Luís & 270 \\
\hline AMAI & Grajaú & 82 \\
\hline Autódromo II & Cidade Dutra & 60 \\
\hline Chácara do Conde - Fase I & Grajaú & 114 \\
\hline Jardim Icaraí & Grajaú & 268 \\
\hline Vila Arco-Íris/ AMAI & Grajaú & 82 \\
\hline Vila Torino & Cidade Dutra & 200 \\
\hline \multicolumn{2}{|c|}{ Total } & 13.913 \\
\hline
\end{tabular}

Fonte: Prefeitura do Município de São Paulo, 2000.

Secretaria da Habitação e Desenvolvimento Urbano - SEHAB

Org: Patrícia Maria de Jesus 


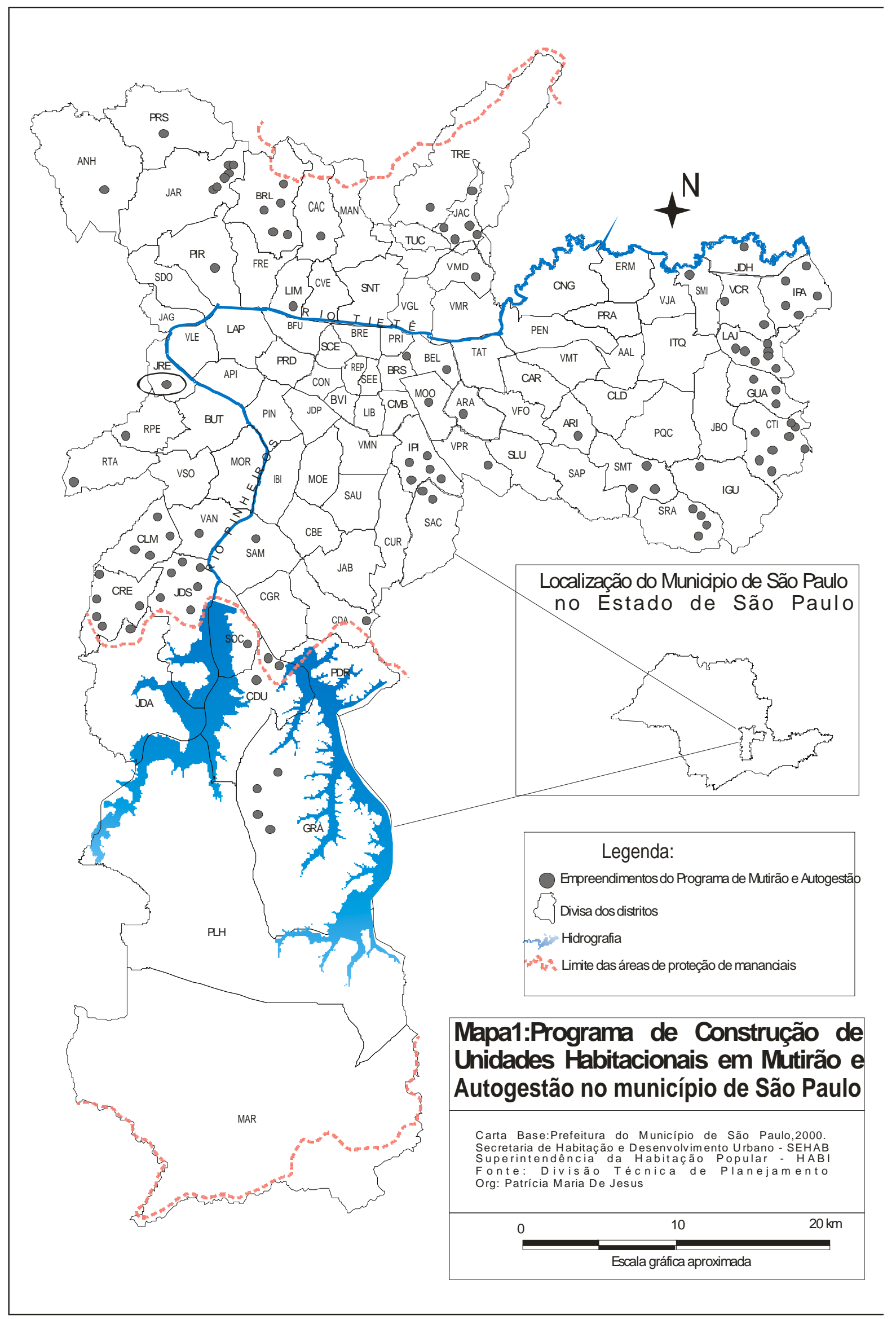




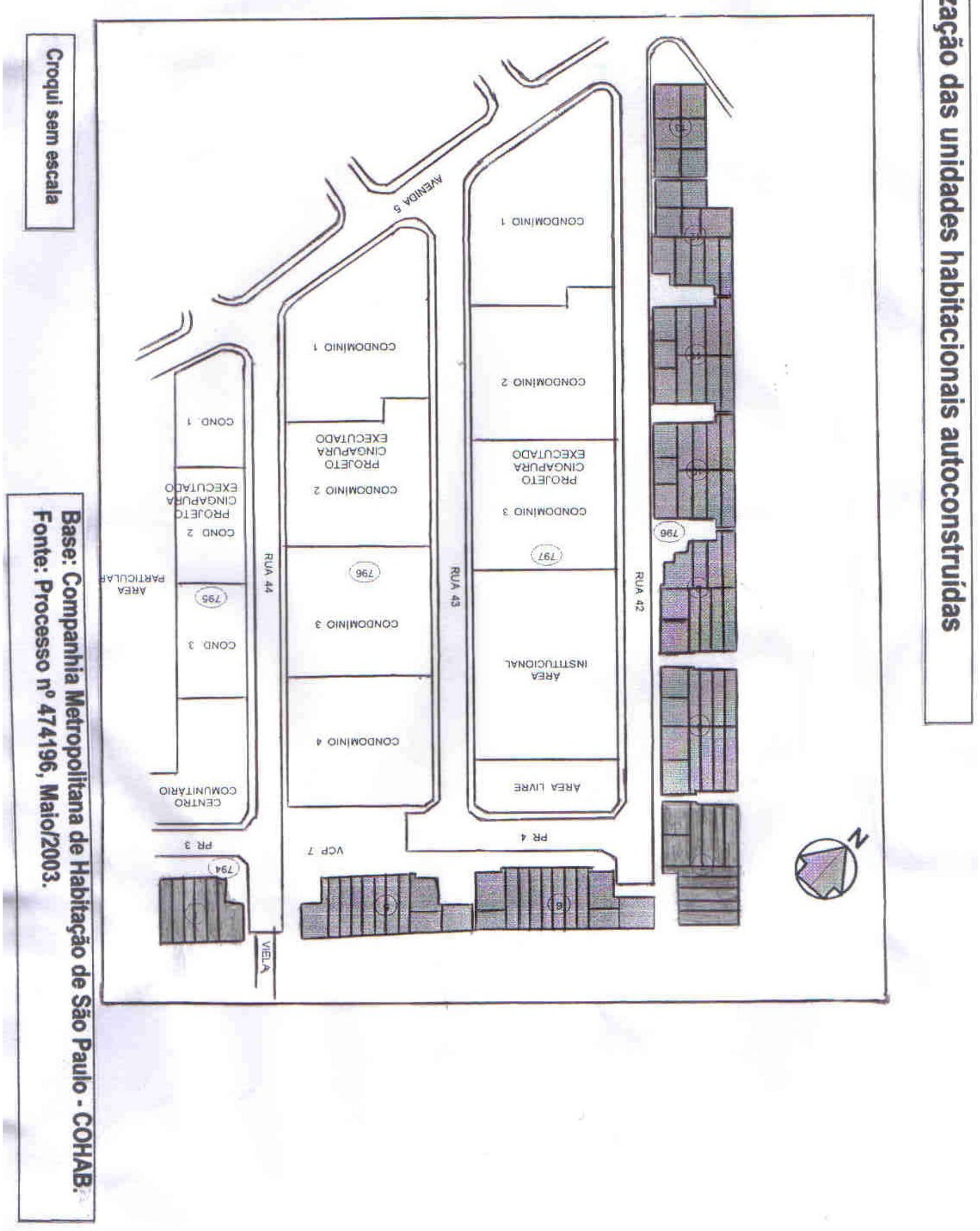


1.8 O Mutirão Estrela Guia.

De acordo com Cláudio, o Movimento começou por volta de 1988-1989, no distrito do Rio Pequeno, com a reivindicação inicial de 25 famílias, quando da ocupação de um terreno (uma faixa de terra no referido distrito). Após a ocupação, tais famílias concluíram que o local era pequeno para qualquer tipo de empreendimento coletivo, como por exemplo, hospital ou conjunto habitacional, e iniciaram novo processo de luta unindo-se com outras famílias no distrito do Jaguaré que também reivindicavam moradia.

"Até aí de 25 a gente virou 100, foi quando a gente conseguiu, conquistou essa área, depois dessa ocupação lá [referindo-se à ocupação do Rio Pequeno] através da Luiza Erundina que tava tomando posse naquele ano. (...) El [referindo-se a Luiza Erundina ${ }^{46}$ já estava junto com a gente - vamos aqui, vamos acolá, vamos atrás de terreno, até em Carapicuíba a gente foi, até na Aldeia de Carapicuíba a gente foi procurar terreno" 47 .

A construção do Mutirão começou no dia $1^{\circ}$ de junho de 1991. Em anexo, consta o regulamento de obras instituído pelos próprios mutirantes. Nele encontramos a definição do sistema de ajuda mútua, no qual seriam construídas suas casas:

Entende-se por Sistema de Ajuda Mútua aquele em que a execução das obras é efetivada mediante a contribuição em horas trabalhadas pelos próprios interessados, sendo que a contratação de mão-de-obra externa será admitida onde a capacitação técnica para determinada tarefa ou a exigüidade dos prazos para sua execução a justifiquem. (21/04/1991).

Até aqui, fizemos a revisão dos registros oficiais e da literatura sobre o tema a respeito do Programa de Produção de Unidades Habitacionais Mutirão e Auto Gestão. Doravante, apresentaremos a versão dos sócio-mutirantes, aqueles que construíram efetivamente o Mutirão Estrela Guia.

46 Inserções nossas.

47 Informação verbal concedida em entrevista realizada em 28/02/2007. Sempre que reproduzirmos as falas dos moradores não seremos fiéis a elas, corrigindo minimamente a ortografia e a gramática. No entanto, o raciocínio e 0 sentido de seus depoimentos permaneceram os mesmos. 


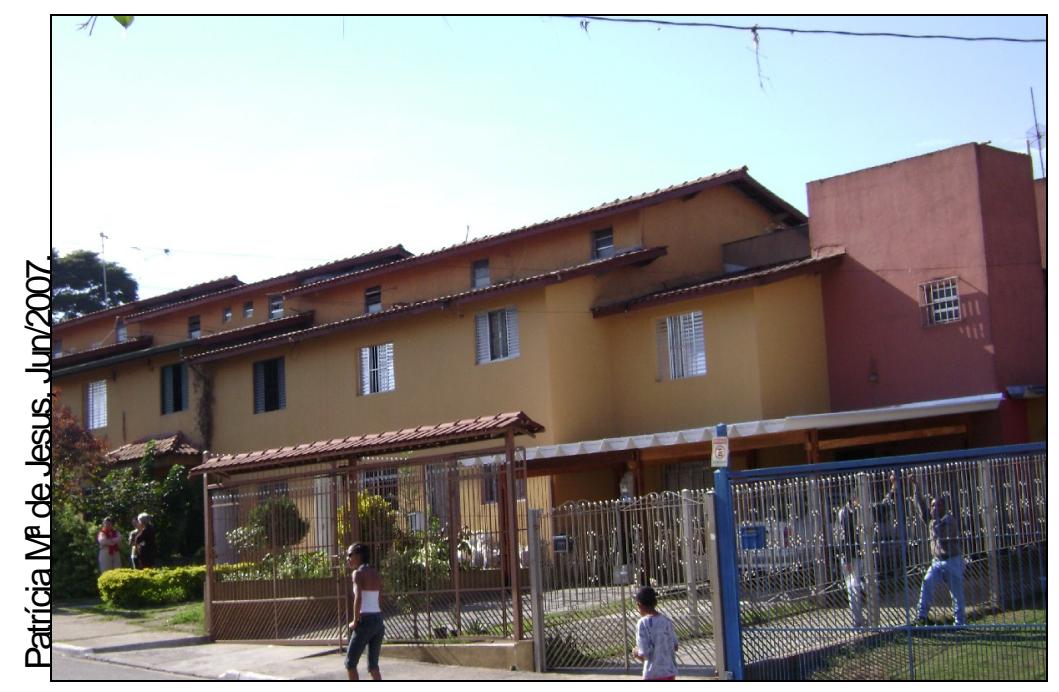

Foto 1: Casas do Mutirão Estrela Guia e exemplo de garagens construídas pelos moradores no recuo frontal dos lotes.

Para fazer nossas interlocuções, não estabelecemos a priori quantidade, roteiro, ou critério para escolher as pessoas que entrevistamos. A metodologia empregada aqui foi construída no interior e no processo da pesquisa de acordo com a necessidade. Significa dizer que, se a proposta é pensar o espaço construído a partir daqueles que o habitam, é também a partir de seus discursos, lembranças e representação que montamos a metodologia em questão. Ou seja, a partir de seus discursos e opinião construímos os critérios para as entrevistas e não o contrário.

Para isso, fizemos uma prévia sondagem com os moradores no sentido de detectar a partir de seus discursos e lembranças, quais moradores contribuíram mais detidamente no processo de construção e autogestão do Mutirão Estrela Guia. Essa sondagem foi feita de maneira mais espontânea possível, sem 0 uso de registros, ou questões diretas sobre 0 assunto. Acreditamos que dessa maneira, não correríamos o risco de entrevistar pessoas "sob encomenda". Participando de conversas, e em momentos de sociabilidades das pessoas do lugar, fomos montando nossa estrutura metodológica ${ }^{48}$.

A partir daí, pudemos constatar que a demanda interessada constituía-se de pessoas de diferentes situações de moradia: aluguel, núcleos de favela, moradias cedidas, e/ou

48 Deixamos claro que colhemos opiniões quer de moradores do Mutirão como também de moradores dos prédios das Operações Interligadas (construídos imediatamente após a conclusão de maior parte do Mutirão), pois em contato uns com os outros conhecem as histórias dos dois empreendimentos. 
emprestadas, áreas de risco etc, predominando segundo os moradores os egressos de aluguel ${ }^{49}$. A situação de moradia fez parte da construção de nossos critérios, porém, levamos em consideração também, outros aspectos como: diferentes procedências no interior dos distritos do Rio Pequeno e do Jaguaré (uma vez que, como já apontamos dois grupos dos referidos distritos, estiveram desde o início reivindicando e lutando por moradia), suas relações com o espaço anterior de moradia, e suas participações no Mutirão. ${ }^{50}$ É razoável considerar que um número muito maior de pessoas foi fundamental no processo de construção e autogestão do Mutirão Estrela-Guia, se verificarmos, por exemplo, as diferentes atribuições nas frentes de trabalho do Mutirão constituídas pelas equipes ${ }^{51}$. Porém, julgamos interessante e legítimo dar voz tanto à moradores que tinham papel de liderança, coordenação em alguma das equipes de trabalho, como também, à moradores que executaram "somente" trabalho braçal na construção do Mutirão e ainda moradores que participaram de uma forma menos direta, mas não menos importante para viabilizar o Mutirão Estrela Guia.

Todas as entrevistas foram concedidas em suas próprias casas, entre os meses de Fevereiro e Abril de 2007.

Apresentamos adiante nossos interlocutores ${ }^{52}$, que fazem parte do "mito fundador" do Mutirão Estrela Guia. De acordo com eles próprios, outras pessoas deveriam ser entrevistadas pela importância e contribuição no referido movimento. No entanto, algumas já faleceram, ou não moram mais no Mutirão.Em outros casos, a proposta da entrevista não foi aceita por algumas pessoas.

1.9 Autoconstrutores - Entre ideais, conquistas e frustrações.

Cláudio pagava aluguel no distrito do Rio Pequeno, em suas palavras "sempre... desde molequinho eu sempre participei de Sociedade Amigos de Bairro, reivindicação para asfalto, água, luz, essas coisas todas". Segundo ele, sua relação com o lugar anterior de moradia era

${ }^{49}$ Contatamos a COHAB (Companhia Metropolitana de Habitação de São Paulo) (órgão que administra o Fundo Municipal de Habitação e onde atualmente encontram-se os documentos referentes aos mutirões construídos na administração de Luiza Erundina de Souza) para um conhecimento mais apurado da situação anterior de moradia dos moradores do Mutirão Estrela Guia. No entanto, não há nos registros consultados dados sobre a demanda que constitui o Mutirão Estrela Guia. Os dados disponíveis (e os únicos existentes) referem-se fundamentalmente aos aspectos técnicos e financeiros do projeto.

50 As pessoas participantes das iniciais reivindicações e iniciais contatos com Prefeitura Municipal tinham a incumbência de convidar outros cinco chefes de família de seu convívio social para fazer parte do Movimento. Assim foi alcançado o número ideal para o empreendimento, de 100 famílias. Desse modo também, dificilmente alguma família veio de outros distritos da cidade, o que certamente não exclui por completo essa possibilidade.

51 Ver em anexo organograma e descrição dos níveis de competência do Mutirão.

52 Todos os nomes dos entrevistados foram trocados. 
tranqüila até o dia em que juntamente com outros moradores, ocupou um terreno ainda que pequeno, para chamar atenção da Prefeitura para o problema colocado: "E na noite que a gente ocupou o terreno lá, até as pessoas que falavam bom dia para você naquele dia era como se você fosse um extraterrestre que caiu ali naquele terreno. Terrível". De seu depoimento, inferimos que sua relação com o bairro onde nasceu e cresceu, e onde sempre esteve envolvido com questões coletivas e por isso conhecido por sua atuação, foi ameaçada quando o mesmo teve a idéia de colocar em prática a ocupação de um terreno. Transgredir a ordem (nesse caso ocupar um terreno) conferiu-lhe, a desaprovação de muitos daqueles que sempre o apoiaram, o que culminou inclusive com sua prisão na noite do ocorrido53.

Cláudio era o coordenador do Mutirão até entrar em conflito com outras lideranças em virtude das prestações de conta, uma vez que era de sua responsabilidade a liberação dos cheques para compra de materiais.

Dona Maria da Graça morava no Sapé (núcleo de favela) localizado no distrito do Rio Pequeno. Veio de Campos dos Goytacazes no Estado do Rio de Janeiro e morou na Favela do Sapé por mais de 20 anos, onde criou sozinha todos os filhos. E gostava bastante, com os vizinhos próximos tinha uma ótima relação, que jamais conseguiu igual no Mutirão. "Não sei explicar, assim, ás vezes eu tenho saudade de lá. Não sei, parece que o pessoal era mais unido lá. Parece não, era sim" 54. Quis sair da favela para ter uma casa e também em virtude da violência urbana. "Mas o que preocupava era o tipo de violência que tinha. Muito tiroteio. Sempre tinha que ter cuidado, a gente vivia se enfiando debaixo das coisas por causa de tiroteio né?'. Concluímos de sua fala que os laços de solidariedade da favela, não foram reproduzidos no Mutirão. Até hoje Dona Maria da Graça não conseguiu empreender na casa melhorias como pintura interna, colocação de pisos e azulejos, etc... Dona de casa, esperou dos filhos tais melhorias que não vieram, uma vez que cada um deles, num intervalo muito curto de tempo, emanciparam-se. Por outro lado, Dona Maria da Graça foi acometida por um câncer no esôfago que a impediu de ocupar-se com tais questões. Todavia, ela considera isso um detalhe, pois o mais importante, isto é, a casa, já foi conquistada. No Mutirão a referida senhora lutou muito, "fazendo massa, carregando bloco, subindo nos andaimes, ajudando os homens".

53 "Eu fui para delegacia preso. Fui prestar esclarecimento, porque houve denúncia da própria população, eles se viraram contra a gente. Mas aí chegou na delegacia, o delegado viu que não tinha artigo para me enquadrar, então eu fui liberado".

54 Informação verbal concedida em entrevista realizada em 07/03/2007. 
Dona Sônia sempre residiu no Jaguaré, na rua Foresto Bandecchi, como ela faz questão de frisar. A referida rua fica a poucos metros do Mutirão. Sua relação com o bairro e com a vizinhança sempre foi ótima. Como sempre morou no mesmo bairro, não teve problemas em relação ao novo espaço de moradia. Justamente pela proximidade, Dona Sônia sempre volta ou passa por lá. Até porque um de seus filhos, atualmente casado, alugou uma casa exatamente na mesma rua. São suas palavras: "O Rodrigo foi morar na mesma rua $E$ todo mundo [com muita ênfase $]^{55}$ conhece a gente, precisa de ver, e é abraço, e tudo, precisa de ver. Os meus filhos foram todos criados nessa rua né? Então para ele foi uma glória, foi alugar a casa, a pessoa já conhecia. Quando desocupou a casa, aí quando viu eu e o Rodrigo, ela disse: Eu não acredito que é você que vem morar aqui. Falei: Não é eu não, é o Rodrigo. Eu gostei"s6..

Sua identidade e vínculo com o bairro só melhoraram, segundo ela, depois de vir morar no Mutirão. Por um lado, porque tendo sempre residido no Jaguaré ao mudar $p /$ o Mutirão a poucos metros de sua residência anterior, passou a conhecer mais ainda outro "pedaço" do bairro, e por outro, o dinheiro empregado no aluguel é agora investido na própria casa, de onde só sairá quando morrer, como ela nos diz enfaticamente. A casa é desse modo, a garantia de permanência no bairro onde sempre morou, em que os filhos todos foram criados, e onde ainda residem mesmo após terem se emancipado.

"Eu saí do aluguel e faz mais de 15 anos que a gente não paga. Aí o dinheiro que era da gente pagar aluguel, faz uma reforma, faz um piso, reboca. Investe no que é da gente. Que a gente veio aqui no rústico. Só no barro, sem água, sem luz, a luz era emprestada, depois não dava certo, porque queimava os aparelhos domésticos do homem".

Neuma também pagava aluguel, num bairro distante do Jaguaré, cerca de cinco quilômetros. No Jardim Bonfiglioli nasceu e cresceu, conhecia bem o bairro, sua relação com todos os vizinhos e suas amizades eram muitos boas. São suas palavras:

"Eu senti muito [diz enfaticamente] ${ }^{57}$ de mudar para cá devido a grande amizade que eu tinha lá com o pessoal. Então assim, quando o grande dia chegou vieram várias coisas na minha cabeça. Veio alegria de saber que eu ia deixar para trás o aluguel, que é um dinheiro que você dá aquele dinheiro, mas não tem volta. Mas, assim ao passar dos meses eu percebi que eu assim fiquei feliz pela conquista da minha casa que era meu sonho. E eu vi esse sonho concretizado. Só que eu senti falta dos meus amigos, que eu deixei para trás. Então eu ficava um pouco assim isolada, eu

\footnotetext{
55 Inserção nossa.

56 Informação verbal concedida em entrevista realizada em 11/03/2007.

57 Inserção nossa.
} 
ficava no meu mundo, por falta dos meus amigos. Então o que me trouxe tristeza foi a falta dos meus amigos" $" 58$.

Além do desafio de construir a casa, Neuma sofreu com a distância dos amigos, e no processo de mudança para o Mutirão outro desafio era lançado: estabelecer novas relações de amizade, companheirismo e confiança, que no antigo lugar de moradia foram conquistados em longos anos de convívio.

No Mutirão, além de auxiliar na construção das unidades habitacionais, Neuma também era responsável pelo cuidado com as crianças que, acompanhando os pais passavam todo o fim de semana ali. Fazia parte do regulamento a não admissão de crianças menores de 15 anos em qualquer das fases do trabalho. Desse modo, Neuma grávida do primeiro filho era encarregada de inventar jogos e brincadeiras, manter as crianças longe das máquinas e equipamentos, distraí-las. Por esse motivo, sempre dedicou especial atenção às crianças daquele período que hoje são jovens. Àesse respeito ela se expressa:

"Eu acho sim que foi importante a conquista da casa, mas eu particularmente acho que não deveria parar só na conquista da casa. Precisava ter outros ideais, trilhar outros caminhos, por exemplo, aqui existe muita criança, muitas crianças, entre as crianças do Mutirão, as crianças dos prédios. Então eu acho que devia ter um projeto mais visado para criança. Mas um projeto sério. Não só as 100 famílias, mas o próprio governo, a sociedade mesmo dar o parâmetro de estar implantando aqui dentro um projeto de cultura que é importantíssimo para criança, esporte. (..) Porque eu vejo também, que o espaço, não por causa dos prédios, mas o espaço se tornou pequeno, então idéia nós tínhamos, mas... Se tornou um espaço grande, mas se tornou pequeno, porque se fez muita moradia que é o ideal, mas não se pensou no lazer.(...) Mesmo tendo o Centro Comunitário, mas você vê o que aconteceu? Não tem nem condições. Então precisava ter assim um espaço maior para ter, por exemplo, uma localidade de esporte, quadra para crianças. Tem uma quadra aí, mas essa quadra não tem nem condições. Mas eu acho que devia ter uma visão mais aberta, uma visão mais definitiva. Precisava de várias quadras, playground para as crianças, esporte por faixa etária. Porque aqui tem desde criança pequenininha até jovem Quantos e quantos jovens, todos eles eu vi crescer, e hoje estão aí tudo parado sem fazer nada. (...) O que você vê hoje é a criançada para se divertir que acaba brincando na rua, correndo risco na rua por não ter espaço ideal, adequado".

Observamos que Neuma apesar de bastante crítica em relação às necessidades atuais do Mutirão, acredita que um projeto sério para as crianças do empreendimento em sua totalidade (as casas do Mutirão e os edifícios das Operações Interligadas e Cingapura) deve cumprir uma

58 Informação verbal concedida em entrevista realizada em 21/03/2007. 
determinação externa (do governo, da prefeitura, da sociedade). A opinião dos moradores sobre seus desejos e perspectivas não é levada em consideração na sua fala.

Importante também que sua visão de conjunto habitacional remete a idéia de Getúlio Vargas no período de 1940. (ver nota 41).

Dona Alzira morava no Morro, situado entre o Jaguaré e o bairro de Presidente Altino (município de Osasco). Destaca que não morava na favela apesar de sua casa ser de madeira. A área era particular e pertencia a um senhor para quem seu falecido marido trabalhava limpando, e carpindo terrenos, e criando animais como galinha, porco e coelho. Em troca do serviço foi concedida à Dona Alzira e seu marido uma parte do terreno, para que morassem com os filhos pequenos. Lá moraram muitos anos, calcula 20 anos após pensar muito. Foi para o Mutirão antes mesmo de iniciado o processo de construção das unidades habitacionais. Devido ao tamanho da gleba e da falta de segurança, os mutirantes decidiram àquela época que alguma família deveria ser guardiã da área, a fim de inibir eventuais invasões. A família da Dona Alzira foi eleita para essa tarefa. Moraram num barracão por muito tempo até que todas as casas ficaram prontas. Só então, puderam ocupar uma das 100 casas que ajudaram a construir. Seu falecido esposo, já doente há muito tempo, viu seu sonho ser realizado, ainda que por pouco tempo, pois após adentrar a casa vivera poucos meses. Dona Alzira não se lembra bem, mas arrisca dois meses.

Sua participação na conquista pela moradia, bem como a representação que faz dela é bastante interessante.

"Eu como dona de casa não saía quase para fora porque não tinha tempo. (...) Porque era o pai dela [referindo-se à uma das filhas que participou ativamente da Iuta pela moradia ${ }^{9}$ que vivia andando com ela, com eles e eu ficava em casa com as crianças porque eu cuidava de muita criança, cuidava de neto, filho assim dos outros, dos meus netos em casa, fiquei mais de dois anos com meus netos, do filho mais velho em casa, que era muita criança. (...) Aí a gente teve que lutar, eles lá, eu não, que eu só vivia trabalhando aqui, ajudando na cozinha, fazendo as coisas, fazendo bolo, cozinhando milho, fazendo café, chá, várias coisas ${ }^{60 "}$.

\footnotetext{
59 Inserção nossa.

60Informação verbal concedida em entrevista realizada em 10/04/2007. No último trecho da fala referindo-se ao período de transição entre a administração de Luiza Erundina e a administração de Paulo Maluf quando os repasses de recursos financeiros cessaram e o Mutirão Estrela Guia, assim como outros da cidade, tiveram que arcar com recursos próprios para finalizar suas obras. Em decorrência desse fato, as obras do Mutirão foram finalizadas na década de 2000, quando o empreendimento do PROVER no mesmo local já estava inclusive pronto. Levando em consideração o início do processo de luta, 1990, 1991, a consolidação do Mutirão durou mais de uma década.
} 
Mesmo reconhecendo que cuidava de muitas crianças; seus filhos, netos, filhos de outros mutirantes, e também fazia várias coisas para arrecadar fundos para o Mutirão, Dona Alzira é enfática ao dizer que não participava de "nada não". Contudo, sem sua colaboração o processo de construir e autogerir o Mutirão certamente teria sido mais difícil, inclusive, para aquelas pessoas para quem Dona Alzira prestava o seniço de cuidar dos filhos. Vejamos que o fato de ela não "pegar na massa", não estar presente nas reuniões ou no canteiro de obras faz com que ela considere sua participação pouco útil. Ter morado junto com a família num barracão por muito tempo com a finalidade de vigiar a área do Mutirão no nosso ponto de vista, foi a maior de suas contribuições, porém, esse fato é lembrado por ela como um cumprimento de protocolo determinado pela assembléia de mutirantes. Tanto no Morro, como no barracão improvisado e na casa construída no Mutirão, Dona Alzira sempre se ocupou das mesmas tarefas: cuidar de casa e de crianças (seus filhos, netos, filhos dos mutirantes).

Do exposto acima, inferimos que o "raio de ação"61 de Dona Alzira é e sempre foi de acordo com ela própria o espaço restrito da casa. "Minha vida sempre foi essa aqui mesmo que você está vendo".

Inferimos também que a dificuldade de interação não impede a participação, mas, não encontra legitimidade por aqueles que compartilham do processo. Desse modo, a participação reconhecida é a dos homens, daqueles que negociam com a prefeitura, ou somente das mulheres mais engajadas. Porém, no Mutirão participam sim, e efetivamente, aquela que longe da massa de cimento faz o almoço sem ser vista, outra que pelo limite da força física ajuda como pode, também aquela que reúne as notas para a contabilidade, ou ainda aquela outra encarregada de ficar longe do canteiro de obras distraindo as crianças. Mesmo que protagonistas da própria luta, há a necessidade de que alguém as lembre disso, pois, por muitas vezes, a consciência da participação no processo político não lhes vem e suas falas são de meras coadjuvantes.

Exceto aqueles desempregados, a demanda era constituída em sua maioria por indivíduos que justamente por trabalharem durante a semana, iniciariam o processo de construção de suas casas aos finais de semana. Interessante perceber que dentre todas as regras para a participação do mutirão, 25 ao todo (ver anexo), aquela que esteve presente em muitas falas, a primeira a ser lembrada com bastante destaque foi a questão relativa ao trabalho aos finais de semana.

Vejamos:

61 Termo de Agnes Heller para referir-se ao alcance das atividades cotidianas exercidas pelo homem humanogenérico. Ver sobre esse aspecto capítulo III desse trabalho. 
"Foi uma luta muito grande. Era Sábado, Domingo, Feriado. A gente não tinha Sábado, nem Domingo, nem Feriado. Porque se não participasse eliminava. Então a gente não parou com a luta (...). Era Sábado, Domingo e Feriado. E se não viesse perdia a casa. Se tivessem cinco faltas tinha que ter justificativa. Quando meus filhos não vinham, tinha vez que eles queriam sair para dar um rolê aí eu segurava a barra, eu vinha. Sábado e Domingo". (Dona Sônia).

"A princípio pra mim foi assim um tanto difícil né? Porque como eu falei anteriormente, pra mim eu não via a hora de chegar Sexta-Feira de tão cansada, então eu tive que trabalhar muito comigo mesma e perceber que pra nós não existiria nem Sábado nem Domingo, então eu perdi muitas festas, muitos convites de casamento, muitas festas de aniversário, muitos dias de descanso, mas, o que me dava, o que me movia a perder tudo isso, todos os meus finais de semana era a conquista da minha casa que era o grande alvo da minha vida, o grande alvo da minha conquista com a minha família" (Neuma).

"Foi muita luta. Luta, luta mesmo. Fazendo massa, carregando bloco, subindo nos andaimes, ajudando os homens. Muita luta. Muito sol. Oha aqui meu braço, todo queimado, foi do sol, de tanto Sábado e Domingo de calor daquele tempo. Então a gente não teve descanso durante uns dois, três anos, trabalhando na semana dentro de casa e trabalhando fim de semana para ter essa casa". (Dona Maria da Graça).

Essa regra, do regimento interno de funcionamento do Mutirão Estrela Guia, permite analisar esse processo sob o aspecto da dupla exploração dos mutirantes. Isso porque, mesmo já tendo trabalhado durante toda a semana, em seus dias de descanso novamente tinham que trabalhar na construção de suas casas. E não eram pagos pela Prefeitura Municipal por isso. Ao contrário, no Programa de Autoconstrução e Autogestão, a mão-de-obra gratuita dos mutirantes era a sua parte na amortização das unidades construídas. Apesar disso, ao final do processo, os moradores ainda esperam do poder público a documentação que lhes confira propriedade das habitações. Esperam tambéme, sobretudo, os carnês para o pagamento das moradias que são suas, pois eles as construíram, ao mesmo tempo não são, pois não há documentação que comprove.

Sobre esse aspecto, Rodrigues (1988) ao relatar o processo de ocupação de terras no município de Osasco tece as seguintes indagações:

É correto o movimento tomar em suas mãos o que é atribuição do poder público? Já não contribuem para a produção social com o seu trabalho? Os movimentos, ao tomarem para si a deliberação de construir com seus "próprios meios", estão sedimentando ainda mais o fetiche da produção da cidade. Não é com recursos do trabalho (FGTS), que se promove, ou pelo menos se deveria promover, a habitação de interesse social? (p.292)

Questões desse tipo fazem parte de todo processo de luta por moradia nas cidades brasileiras. 
Vejamos as considerações de nossos depoentes:

"A única coisa que eu tenho a dizer é que a gente ainda não tem um papel que prova que é da gente, mas a gente sabe que é da gente né? Ano passado um pessoal da Prefeitura veio saber, veio perguntar, para mandar documentação, mandar carnê para a gente pagar e pegar documentação da casa, mas não deu em nada ainda. É a única coisa ruim só é isso. Mas eu tô feliz!" (Dona Maria da Graça).

..."Mas agora, por exemplo, eu, na minha opinião, em mim assim, eu não vejo a hora de chegar aquele papel da Prefeitura, eu ter meu documento, da minha casa, pagar minhas prestações e pronto, porque eu já me aposentei" (Dona Sônia).

"Deus que pôs a mão e fez o Mutirão aqui. E até hoje ninguém pegou o carnê nem nada. Não estamos pagando nada. Só água e a luz. Tem vez que eu deito assime penso: Será que ainda vou receber o carnê para poder pagar isso aqui? Porque ainda não é meu né? Não estamos pagando nada". (Dona Alzira).

"A princípio todos nós temos, nós queremos a escritura. Nós já temos a casa, todo mundo quer a escritura. O pessoal da COHAB chegou vim falar conosco, fez uma reunião, trocou até uns documentos, papel, foi levado tudo para a COHAB. Só que até hoje nós não temos assim um retorno, então nós estamos aguardando um retorno pela $\mathrm{COHAB}$. Então todo mundo não vê a hora de ter suas escrituras. Para concretizar: essa é a minha casa mesmo" (Neuma).

Somente Cláudio tem outra perspectiva sobre o mesmo problema:

"O Serra quando assumiu, logo nos primeiros dias apareceu gente aqui. Só que a proposta que eles vieram aí não condiz com a realidade. Por exemplo, eles querem cobrar, eles querem que a gente pague o valor venal, o valor como se tivesse entrado aqui hoje, com tudo pronto. (...) Eles querem colocar tudo na balança. Ees não sabem da ampliação que eu fiz. Hoje a minha casa tem três dormitórios e uma suíte. Eu fiz uma garagem também, né? Isso aí tudo eu fiz com meu recurso próprio. Então a gente vai ter que negociar isso aí (...) Que valor que eu vou pagar? Né? Ea minha mão-de-obra? Quer dizer que a mão-de-obra do Mutirão então não valeu de nada? (...) A idéia do Mutirão é você pagar uma parte da sua casa em mão-de-obra. (...) Quando você admite que sua casa vai ser construída em mutirão você já tem que saber que a parte dessa parcela, desse montante, do valor total vai ser paga em mão-de-obra. Então a minha casa eu já paguei, minha parte. Esses que caíram aqui de pára-queda agora nem sabemp2. Cobrar o quê? Eu por exemplo, eu estou aqui de 1993 para 2007? Eu estou aqui há 14 anos, 14 anos que eu moro aqui. Então se fosse uma área particular eu já tinha direito a usucapião, como é uma área municipal eu não tenho. Então como é que faz? E esses 14 anos que eu fiquei velando aqui. A questão até mesmo do zelo, porque até quando as casas não estavam prontas, a gente evitou aqui inúmeras ocupações ${ }^{63}$.(...) Então assim, até nisso, o zelo pelo patrimônio público que a gente também contribuiu. Tudo isso acho que tinha que ser colocado na balança, saber do nosso histórico".

62 Referindo-se aos novos moradores que compraram recentemente casas no Mutirão.

63 Cláudio muda o termo de ocupação para invasão, pois a área já estava ocupada pelos mutirantes. Ele refere-se às inúmeras tentativas de outras pessoas demandantes por moradia que ameaçavam o processo do Mutirão e que queriam permanecer lá de qualquer maneira. 
Apresentar a história do Mutirão Estrela-Guia não constitui tarefa fácil, pois, a empreitada da luta que materializou o empreendimento é cheia de percalços e obstáculos que normalmente caracterizam qualquer movimento social urbano ou rural. Contudo, um aspecto dessa expedição chamou-nos a atenção e analisá-lo permite compreender os vínculos dos moradores com o espaço vivido por um outro caminho não considerado a priori por nós.

Esse aspecto é relacionado aos inúmeros conflitos vividos pelos moradores no processo de construção e autogestão do Mutirão e também no processo de pós-ocupação. Vamos a eles.

De acordo com Cláudio, primeiro Coordenador Geral do Movimento, os impasses iniciais ocorreram em virtude do repasse do recurso financeiro da Prefeitura Municipal para a gestão do Mutirão. Como já apontamos, a compra do material de construção, a contratação da mão-deobra especializada, a escolha e contratação da Assessoria Técnica que desenharia o projeto das futuras moradias, bem como o pagamento desses serviços, e outros aspectos relacionados à administração financeira, eram decididos em assembléias. Em sua opinião, quando algumas pessoas perceberam que a quantia em dinheiro repassada pelo poder público municipal era vultosa, houve a "má" intenção quanto aos rumos do Mbvimento a partir daquele momento. São suas palavras:

"Então daí a gente percebeu que assim, aquela coisa de fazer com que o Mbvimento andasse, a gente percebeu que tinha toda uma má intenção do Movimento andar engatinhando mesmo, porque tinha um interesse por trás daquilo. Porque o dinheiro caía, eu assinava cheques em branco por confiança no pessoal do Movimento, mas depois a prestação de conta não batia. (...) Quando eu na Coordenação Geral passei a exigir uma prestação de conta melhor do que aquela que estava sendo feita, onde só aparecia o total, não tinha discriminação do que tinha sido comprado, as brigas começaram".

O regimento feito pelos mutirantes era claro quanto às faltas: cinco delas injustificadas eliminavam a participação no Mbvimento. No entanto, uma numerosa e influente família passou a exercer domínio sobre todo o processo, desde a Coordenação (uma vez que Cláudio desistiu de sua função) até a formação da opinião de muitas outras famílias, como veremos adiante.

Segundo ele, eram "dois pesos e duas medidas", pois as pessoas ligadas à nova coordenação gozavam de privilégios.

"A gente passou a perceber, por exemplo, que o padrão de vida que elas levavam ${ }^{4}$ já passou a mudar, elas vinham trabalhar, chegavam no Mutirão de táxi, enquanto

64 Referindo-se às pessoas da nova coordenação. 
outras pessoas vinham e voltavam do dia de trabalho a pé, ou faltavam e tinham vergonha de dizer justamente que faltavam por não ter dinheiro".

Ainda sobre esse aspecto:

"Pagamento de casamento sabe? De festa, viagem para o litoral, quantas vezes elas ou a família delas não estava aqui trabalhando e você ia perguntar estava no litoral, famílias em casa no litoral bancada com o dinheiro daqui, sabe? Não dá. Pior que não tinha como você provar, porque eles faziam um negócio tão direitinho, ou mesmo não fazia direitinho, mas você não tinha como peitar eles".

Em suma, para Cláudio e outras pessoas com as quais conversamos, muitas vezes o dinheiro tinha outra finalidade que não as necessidades do Mutirão. De acordo com essas pessoas, paredes eram levantadas e imediatamente após, eram derrubadas sem explicação convincente aos mutirantes.

Oápice do conflito consistiu na ocupação de algumas unidades habitacionais do Mutirão antes de todas as 100 casas estarem prontas. Vários motivos suscitaram a idéia dessa ocupação65. Todavia, somente quatro famílias mutirantes ocuparam as casas, dentre elas a de Cláudio, que só a ocupou em solidariedade às outras três. Dessas três, uma passava por ação de despejo em virtude da subida do valor do aluguel, outra não podia pagar o aluguel, pois a empresa na qual trabalhava acabara de abrir falência Os filhos tanto de uma quanto de outra família eram menores e, portanto, impossibilitados de auxiliar substantivamente. O barraco da terceira família estava localizado em um pequeno núcleo de favela na "baixada do Sapo", distrito do Rio Pequeno, às margens de um córrego atualmente canalizado em virtude da construção da Avenida Escola Politécnica6 ${ }^{6}$. Por situar-se em área de risco e prestes a desmoronar devido às enchentes do período, o barraco seria removido em poucos dias e a Prefeitura Municipal apresentou para essa família a proposta de transferência para o distrito de Pirituba. Vale ressaltar ainda que as pessoas responsáveis dessas três famílias em questão são mães solteiras.

Antes de optar pela ocupação das casas, o problema foi transmitido para a nova coordenação do Mbvimento com a proposta de ocupar quatro das casas prontas e quando todas as 100 estivessem erigidas, participariam normalmente do sorteio (uma vez que todos os mutirantes auxiliavam na construção de todas as casas), desse modo não havia como saber qual casa seria de qual família.

Duas sugestões vieram da coordenação: pedir auxílio ao padre da paróquia, ou contar com a ajuda de parentes. Insatisfeitos com tal resposta decidiram pela ocupação.

${ }^{65}$ Consta em anexo a Proposta de Ocupação.

66 Importante via de acesso da região que liga a Marginal do rio Pinheiros à rodovia estadual Raposo Tavares. 
"Mas e aí? O que vocês estão pensando? 'A gente tava pensando de cair para dentro das casas no próximo final de semana à noite'. Eu falei: - Não, nós vamos cair, nós vamos para dentro das casas é de dia, pra todo mundo saber porquê que nós estamos fazendo isso." (Cláudio)

"Então no dia 04/10/93 às 8:00 da manhã a gente entrou aqui com os caminhões de mudança. (...) E avisamos o pessoal lá no Rio Pequeno que a gente podia sofrer algum tipo de represália. Então como de fato a gente foi ameaçado de tudo quanto foi jeito". (idem).

Vimos até aqui, que a tão proclamada autogestão dos empreendimentos por parte da Prefeitura Municipal aconteceu no Mutirão Estrela Guia da forma mais árida possível. A falta de preparo de uns e a ganância de outros, gerou toda sorte de conflitos. A relação entre as lideranças, que já não ia bem em virtude dos rumos das verbas, e do tratamento com as pessoas, a partir da ocupação das quatro unidades prontas tornourse motivo para inúmeras situações e fatos de ameaças, linchamentos, indignações, proibições, expulsões, conivências. A confusão cotidiana dos sócio-mutirantes à época da implantação do empreendimento implicou sobremaneira na vida cotidiana do Mutirão atualmente.

As quatro famílias que ocuparam as casas vizinhas umas às outras passaram por intensa discriminação e ainda hoje são conhecidos como "invasores".

"Então daquele dia 04/10/93 às 8:00 da manhã até bem pouco tempo atrás mais ou menos, olha todo o tipo de represália, e de humilhação e de perseguição que um ser humano pode sofrer, tem os outros de testemunha, você pode perguntar, a gente sofreu aqui nesse Mutirão". (idem).

Sobre esse assunto vejamos alguns pronunciamentos:

"Teve muita briga, muita coisa. Muitas pessoas fizeram diferença. Como o que aconteceu com o pessoal lá embaixo. Mas eles não estavam errados. Eu defendi, eu falei: - Eles não estão errados, eles somente ultrapassaram o estatuto, o regulamento, somente isso. Então as pessoas fizeram diferença com eles e com todo mundo que também defendeu eles. Porque se eles trabalharam direitinho, estavam juntos desde o começo né? Ees não estavam errados". (Dona Maria da Graça)

"Nós fomos proibidos de falar com eles, proibidos mesmo. Mas onde já se viu né? Eu não achava certo não. Então quando eu ia na feira, ou qualquer lugar e tinha que passar perto da casa deles, eu tinha muita amizade com a Dona Lurdinha. Eu passava quietinha, mas jogava bilhetinho, pra gente se encontrar, pra conversar, porque no Mutirão tinha que ficar muda com eles. Muitas vezes eu fiz isso". (Dona Alzira) 
"Me mudei aqui na marra. Foi uma crítica com os outros moradores né? Só quatro que morava aqui. Mas depois aceitaram... ${ }^{67 "}$. (Dona Sônia)

A discriminação quanto às quatro famílias ocupantes das iniciais casas erguidas perpassou inclusive o microcosmo do Mutirão repercutindo inclusive, na Prefeitura Municipal, anos depois do ocorrido. Para A. Rodrigues "a situação de conflito não é expressa apenas num momento, mas sim num período de tempo" (1988.p.8). Nesse caso, o que vemos é exatamente isso. Importante também frisar que num contexto de carência a circunstância de conflito é inerente.

Conforme já fizemos referência, os repasses financeiros para os mutirões foram suspensos quando finalizada a administração de Luiza Erundina e iniciada a de Paulo Maluf. Quando Marta Suplicy venceu o sufrágio para o cargo do executivo paulistano em 2000, ela retoma, ainda que timidamente, as obras em alguns mutirões $^{68}$. Nesse contexto, o Mutirão Estrela Guia estava quase pronto, no entanto, as casas à época, não tinham ainda pintura extema. A referida prefeita destina então, naquele momento, tinta para cada família viabilizar a pintura de sua casa de acordo com o padrão estabelecido entre os moradores e a Prefeitura. Todavia, das 100 famílias, as únicas que não receberam tinta para realizar a pintura, foram justamente aquelas quatro que ocuparam as casas iniciais.

Outro fato gerador de conflito foi a "negociação de vagas" que ocorreu durante o processo. Segundo as pessoas entrevistadas, houve casos de alguns mutirantes serem expulsos por alguma possível falha. № entanto, a família substituta havia "reservado a vaga" ou "negociado a vaga" com os responsáveis pelo cadastramento dos sócio-mutirantes. Desse modo, famílias sem qualquer participação no processo de luta, eram beneficiadas com uma casa no Mutirão. Segundo relatos, atualmente no Mutirão existem 100 casas, mas o número de famílias não corresponde a 100, pois há moradores "proprietários" de até três habitações.

Apresentando a iniciativa de produzir unidades habitacionais em sistema de mutirões autogeridos, Marques \& Saraiva (op, cit) a partir de Ronconi (1995) se pronunciam:

Nesse modelo, o repasse dos recursos é feito diretamente para os moradores, em parcelas, por convênio assinado entre o poder público e as associações de moradores. As associações gerem todo o processo, apoiadas por assessorias técnicas contratadas pelos moradores, prestando contas das parcelas ao poder público. Nesse caso, os ganhos do programa vão além da redução dos custos e estão associados à maior agilidade gerencial (quando comparada com o poder

67 Dona Sônia não entra no mérito dessa questão.

68 O que deveria ser regra constitui-se como exceção, pois a continuidade administrativa quase nunca é observada. E nesse caso arriscamo-nos dizer que só o foi em virtude da mesma filiação partidária das referidas prefeitas. 
público), ao aumento da organização dos mutirantes e da apropriação do espaço construído, beneficiando inclusive o convívio nos futuros conjuntos. (p.273)

Porém, os fatos que relatamos aqui, e outros impossíveis de serem reproduzidos em virtude da riqueza de detalhes das narrativas, não confirmam essa reflexão e culminaram a nosso ver, na decadência dos ideais de um projeto coletivo, na diferenciação das casas e no isolamento das famílias (exceto aquelas mais numerosas com mais de um núcleo familiar e com relações de parentesco no Mutirão).

"A história do povo desse Mutirão aqui com certeza vai ter isso de diferente de outras histórias. Deviam ser todas iguais, porque as histórias são as mesmas, as origens são as mesmas, o trabalho é o mesmo. (...). Mas foi tudo de propósito, as pessoas tinham que estar alheias, (...) para que eles continuassem mandando. Porque é o que acontece com a maioria dos govemantes. Quer dizer: quanto mais o povo estiver alienado, melhor para eles". (Cláudio).

Daí as alterações, ampliações, construções que não cessam e distanciam o Mutirão do projeto original. Interessa ainda ressaltar, que essas mudanças agora são individuais e não mais coletivas.

"Infelizmente aquele sonho de ter aqui uma verdadeira comunidade, onde a gente tinha uma idéia, por exemplo, até de uma compra de mercado, compra em atacado, comprava junto e dividia para sair mais barato pra todo mundo. (...) tínhamos idéias aqui, pra jovem, aquela coisa toda, criar um balcão de emprego, tudo, a gente tinha tudo isso, tudo e de repente foi por água abaixo (...). Agora é cada um pra si, Deus pra todos, mal falam bom dia um pro outro". (Cláudio)

Quando coletivas, o são para um grupo de vizinhos diretos, não passando por assembléia ou coordenação. E dizem respeito sempre à diferenciação de um núcleo de casas em relação a outros 69 .

"Aqui a moradia passa a ser coletiva. Então, morar coletivamente é você conquistar o seu espaço e ser respeitada e você respeitar também o próximo. A conquista do nosso portão foi união de todos nós aqui que somos 10 casas. Então nós colocamos portão, nós fizemos reunião. Então morar coletivamente é você conquistar o seu espaço (...) tudo que você tem uma idéia você passa para os seus vizinhos, e chegar num objetivo só, e chegar numa conclusão só". (Neuma).

${ }^{69}$ Construído em renque, em algumas áreas do Mutirão existem vilas de 10 casas. 
A colocação dos portões expressa com bastante propriedade a procura da diferenciação, pois, se os moradores de um conjunto de 10 casas optam por um portão para guardar suas habitações, carros, e proteger as crianças, do restante das casas do Mutirão, o que vemos aí, é a clara tentativa de "imitar" a classe média e seu modo de morar em condomínios fechados. Por outro lado, quando a classe de maior renda opta por esse modo de morar a intenção é óbvia: a separação dos diferentes e a união dos iguais. No Mutirão, a colocação dos portões separa os iguais, tanto quanto isso é possível, pois a diferenciação através dos portões somente é notada pelas pessoas moradoras do Conjunto (mutirão e prédios de apartamentos), para aqueles que vêm de fora: comerciantes, entregadores, carteiros, instaladores, etc..., e para aqueles que vêem o Mutirão exteriormente, internamente não há diferenciação, o Mutirão constitui uma totalidade.

Ainda sobre o declínio das idéias coletivas:

"Porque era tudo unido. Era Estrela-Guia quando chegava, eram beijos e abraços, era uma união muito grande, hoje em dia depois que cada um está na sua casa, uma tem uma casa mais bonita do que a outra, uma arruma sua casa, uma não pode. (...) Tem muita gente que eu estou aí na rua assim, passa faz de conta que nemme vê, nemconhece mais". (Dona Alzira).

"Agora não tem nada não. Depois que a gente conseguiu a casa. Parece que as pessoas não têm mais porque ou pra que se reunir. Ficou muito sozinho. Cada um sozinho. Cada um no seu". (Dona Maria da Graça).

Depois de finalizado o objetivo da construção da casa, cessou a reivindicação por quaisquer outros benefícios e/ou melhorias. Arlete Rodrigues em sua análise sobre os movimentos de ocupação de Osasco, sugere que o objetivo de movimentos dessa natureza não seja apenas o de que a população espoliada consiga um lugar para morar, mas também que estes movimentos, deixem saldos políticos e organizativos. Que compreendam o processo de produção e consumo do espaço urbano. Que a esfera do cotidiano seja compreendida na esfera do político (1988). Exatamente o que não aconteceu em nossa área de pesquisa, pois os conflitos suscitados não deixaram saldos políticos e organizativos. Bem ao contrário disso, esses ideais foram declinados e deixaram no âmbito da vida cotidiana outras marcas.

A nosso ver, os conflitos, e as confusões suscitadas por eles que empreenderam o vínculo desses moradores com o espaço habitado. Resistir a eles (pois muitas famílias que iniciaram a empreitada de luta pela moradia desistiram ou foram "obrigadas" a desistir ao longo do caminho) foi a forma de justificar essa luta, a maneira de combater todas as adversidades. $E$ de reconhecer nas casas construídas o suor, a luta, a esperança, e o trabalho de tanto tempo. 
Desse modo, quando refletimos a respeito da (re) construção de identidade e apego ao lugar dos moradores do Mutirão Estrela-Guia, não podemos imaginar que tenham ocorrido a partir da ocupação das 100 casas, pois, na árdua labuta de 16 horas mínimas por final de semana, essas pessoas quando partiam de seus locais e situações de moradia para construir o Mutirão, simultaneamente, construíam relações de pertencimento nesse espaço que ainda não era local de moradia, mas local de trabahho, sociabilidade, sonhos, cansaço e "descanso" e por, tais motivos, já implicados da identidade daqueles que iam dando forma e conteúdo a um espaço "semuso".

Sobre tal aspecto consideremos a fala de Dona Maria da Graça;

"No tempo do Mutirão, depois que a gente trabalhava assim no finzinho da tarde, eu usava essa casa aqui para descansar. Eu colocava alguma coisa no chão e usava assim para descansar. E eu pensava: 'Essa casa vai ser minha'. Eu sempre pensava. Daí quando tinha o sorteio, eu vinha né? E já tinha o sorteio e minha vez nunca que chegava. Daí quando chegou, ele chamou - Maria da Graça Siqueira, está aqui a sua chave! Chave de mentirinha né? Que ainda não tinha porta nem janela. Quando eu fui ver era essa casa mesmo. A casa que eu sempre pensava".

Interessante perceber que a identidade com a casa, no caso de Dona Maria da Graça, ocorreu antes mesmo de ela ter sido sorteada. O que confirma nossas hipóteses de que a identidade com a casa não diz respeito ao lar propriamente dito, mas a todo o processo de edificação das unidades habitacionais, e do Mutirão como um verdadeiro território do cotidiano. Tal assunto será discutido no terceiro e último capítulo do nosso trabalho, onde será relacionado a constituição desse território cotidiano, constituído a partir dos microterritórios do Mutirão, dos edifícios das Operações Interligadas e prédios Cingapura, quando também analisaremos com maior atenção a vida cotidiana desse "universo paralelo".

Universo paralelo, nem tão paralelo assim, na opinião dos moradores que consideram a localização do empreendimento bastante integrada ao tecido urbano do bairro, e integrada também à vida das adjacências. Fundamentalmente por estar muito próximo a um shopping center, templo do consumo da modernidade, implicado de simbologias, ideologias, status; também pela proximidade de todos os meios de consumo coletivos: creches, escolas, universidades, postos de saúde, igrejas, terminais urbanos de transporte coletivo; senviços dos mais diversos: desde sapataria até corretoras de seguros, bancos privados e estatais, escola de idiomas. O mesmo vale para o comércio, desde a tradicional padaria à peixaria e ateliê de pintura. Igualmente no que respeita às infra-estruturas como iluminação, água encanada, acesso e proximidade a importantes vias entre aquelas vizinhas e outras distantes à pouquíssimos quilômetros: Avenidas Escola Politécnica, Corifeu de Azevedo Marques, dos Autonomistas; 
Marginais dos rios Pinheiros e Tietê; Rodovias Estaduais Presidente Castelo Branco e Raposo Tavares.

O fato de o distrito Jaguaré situar-se no limite entre os municípios de São Paulo e Osasco, contribui sobremaneira para essa acessibilidade, haja vista a oferta de transporte coletivo de e para ambos os municípios.

Desse modo, do ponto de vista dos "espaços desintegrados" 70 de onde vieram muitos dos moradores do Mutirão Estrela - Guia, o empreendimento representa um espaço bastante integrado à metrópole. No entanto, somente a localização não é determinante dessa integração. Significa dizer, que morar no Mutirão não implica necessariamente acessar ou usufruir todos os serviços, comércio, meios de consumo coletivos do bairro. Conforme veremos no último capítulo, outros aspectos influenciam o não acesso, dentre eles a carência socioeconômica, de que são exemplos o subemprego e o desemprego, e talvez em decorrência dela o apego ao lugar, o vínculo ao território do cotidiano, que constituem então o universo paralelo do Mutirão.

Marques \& Saraiva (op. cit) relacionam as ações do Estado via políticas habitacionais e processos de segregação socioespacial:

As políticas habitacionais podem contribuir para o acesso dos cidadãos à moradia digna e à cidade em um sentido amplo (...) A produção de habitação social pelo Estado influi positiva ou negativamente sobre os processos de segregação territorial. Positivamente, pois o Estado pode reduzir a segregação ao construir habitação social em locais em que é baixa a presença relativa de grupos sociais de baixa renda Negativamente, uma vez que o Estado pode reforçar a segregação ao construir empreendimentos para os grupos sociais pobres em locais já segregados espacial e socialmente, ou quando remove esses grupos das áreas ricas da cidade. (p.268)

Desse ponto de vista, ao considerarmos a localização do Mutirão Estrela-Guia, está clara a influência positiva, para usar a expressão dos autores citados, na dinâmica de segregação espacial, todavia, se levarmos em conta o pleno acesso aos senviços, meios de consumo coletivos e infra-estrutura do distrito do Jaguaré é necessário avaliar o outro aspecto da segregação, ou seja, o caráter social dessa dinâmica, pois a plena acessibilidade não é alcançada para muitos moradores. Os muros, símbolos máximos dos "enclaves fortificados" 71 de que são exemplos os condomínios residenciais fechados de alto padrão das grandes e médias cidades brasileiras, também estão presentes na paisagem da nossa área de estudo, que denominamos Conjunto Habitacional Parque Continental, soma das casas autoconstruídas e dos

70 Expressão de HAESBAERT, Rogério. O mito da desterritorialização: do "fim dos territórios" à multiterritorialidade, Rio de Janeiro: Bertrand Brasil, 2004.

${ }^{71}$ Expressão de Teresa Pires do Rio Caldeira em Cidade de muros: crime, segregação e cidadania em São Paulo. São Paulo: Edusp/Editora 34, 2000, p.257 -329. 
prédios de apartamentos. Os muros de nosso "enclave fortificado" às avessas impedem uma relação "honesta" com o bairro e quiçá também pode contribuir para reforçar a dinâmica de segregação. Empreenderemos melhor análise sobre esse aspecto no terceiro capítulo.

Para discutir essas dinâmicas e relações, é necessário ainda tratar a constituição dos prédios de apartamento implementados através das Operações Interligadas e do Projeto Cingapura, pois a combinação entre eles é o que culminou no nosso território do cotidiano. Ao leitor o convite: vamos? 
Território do cotidiano: Constituição a partir da política de habitação de Paulo Maluf e Celso Pitta.

2.1 Prover habitação por acaso?. 61

2.20 desmonte da política anterior 62

2.3 A política de provisão de habitação na administração de Paulo Maluf e Celso Pitta...63

2.4 O PROVER (Programa de Verticalização de Favelas)............................................... 65

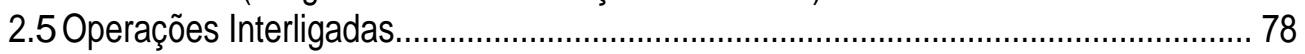

2.6 A implantação do Conjunto Habitacional Parque Continental................................... .81

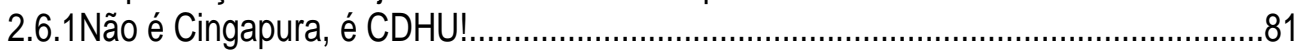

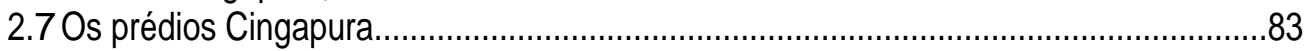

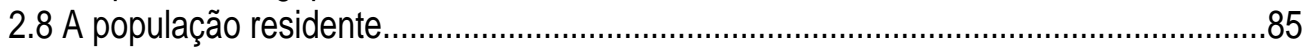

$2.9 \mathrm{Na}$ aparente homogeneidade uma interlocução heterogênea....................................89

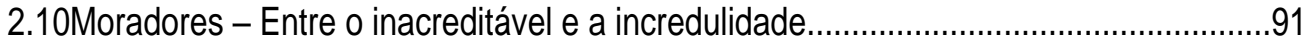

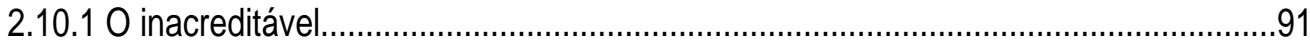

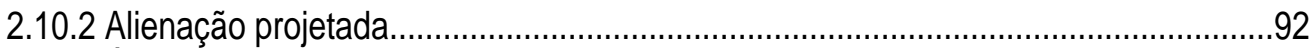

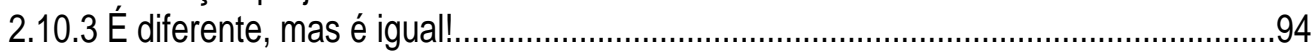

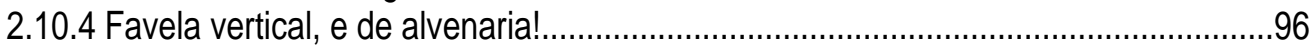

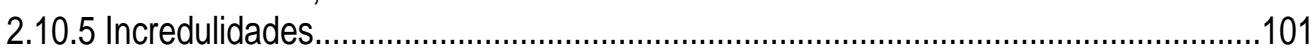

\subsection{Prover habitação por acaso?}

Não por acaso o verbo (classe gramatical que indica ação) da questão acima é prover. De acordo com o dicionário Aurélio, prover significa: 1) Tomar providência acerca de, providenciar. 2) Despachar ou nomear alguém para cargo vago; 3) Abastecer; 4) Dotar, brindar;

5) Atender as necessidades de; 6)Abastecer-se.

PROVER, sigla de Programa de Verticalização e Urbanização de Favelas, é também o nome oficial da política de habitação implementada pela administração Paulo Maluf (1993-1996) e continuada por Celso Pitta (1997-2000), popularmente conhecida como Projeto Cingapura, também não por acaso, mas em alusão à cidade do sudeste asiático, que as referidas administrações municipais entenderam ser o modelo de intervenção pública, no que diz respeito às políticas habitacionais.

Se afirmamos que há intencionalidades na escolha dessas expressões, qual então a relação entre o verbo prover e a sigla PROVER?

Observando as diferentes acepções do verbo listadas acima, está clara a relação. Tomar providência acerca de habitação, brindar ao cidadão uma moradia digna, atender as 
necessidades da população de menor renda. Parecem ter sido essas as preocupações da Secretaria de Habitação das referidas administrações municipais.

E porque seria diferente? Afinal, não são essas preocupações (dentre inúmeras outras) que deveriam fazer parte das agendas políticas das Prefeituras Municipais na implementação de políticas públicas, principalmente em áreas metropolitanas, onde o contingente populacional é imenso, e de igual proporção são seus problemas no quesito moradia?

A fim de responder essas questões, (que norteiam outras, já aludidas por nós em momentos anteriores desse trabalho) é que lançamos a reflexão a respeito de provisão (substantivo do verbo prover), PROVER e Projeto Cingapura72.

2.2 O desmonte da política anterior.

Para compreender a implantação do PROVER é preciso ressaltar que uma vez eleito Paulo Maluf encontrou a estrutura burocrática da Secretaria Municipal de Habitação estruturada para viabilizar a produção de moradias em regime de mutirão. (Silva, 2003, p.28). Além disso, outras experiências estavam em curso: a urbanização de favelas e mesmo a verticalização destas, como foi o caso da favela Minas Gás ${ }^{73}$. Do ponto de vista jurídico, havia o decreto número 29.947 de 07/1991 que legitimava a democrática participação da população nos projetos de habitação popular desenvolvidos pelo poder público municipal. ${ }^{74}$ Ao assumir o executivo paulistano, restava a Paulo Maluf não somente formular outro programa de governo para o setor, e como é comum na política nacional em qualquer nível, (federal, estadual, municipal) diferente do anterior, além de pelo mesmo motivo encontrar outras formas de viabilizar recursos para executá-lo. Para isso, nomeia como secretário Lair Krahenbuhl, empresário com atuação no setor imobiliário do município. Vejamos as citações abaixo retiradas de Silva (op.cit):

Ao nomear o empresário Lair Krahenbuhl para Sehab, Maluf contemplou o setor da construção com um ativo de suas fileiras. Afinal, o titular da Secretaria de Habitação acumula cargo de direção na CBIC (Câmara Brasileira da Indústria da Construção),

\footnotetext{
72 Ainda que PROVER e Projeto Gingapura sejam exatamente a mesma "coisa"; para o cidadão comum, o morador atendido por essa política e outros citadinos (não demandantes de moradia) PROVER "inexiste". O mesmo não se pode dizer de Projeto Cingapura e da representação que se tem dele. Por isso essa última alusão de PROVER e Projeto Cingapura como duas entidades diferentes. Adiante, ao tratar dos aspectos estritamente políticos do programa, nossa referência será PROVER, quando a interlocução se restringir aos moradores atendidos por ele nossa referência será Projeto Cingapura.

${ }^{73}$ Depreende-se daí que a tão proclamada verticalização de favelas nas próprias não foi mérito da gestão Paulo Maluf, como muitos acreditam.

${ }^{74} \mathrm{~A}$ respeito desse assunto além do autor supracitado, ver também Souza (1997).
} 
SECOVI-SP, AELO - associação que representa empresários do setor de loteamentos em São Paulo. (Construção São Paulo, nº 2374, Ago/93).

No primeiro dia à frente da Secretaria, Krahenbuhl já tinha em mãos um projeto para construção de $20 \mathrm{mil}$ unidades habitacionais, entre apartamentos e lotes urbanizados. (Construção São Paulo, no 2374, Ago/93)

Não é demais lembrar que Paulo Maluf, engenheiro civil de formação, é conhecido por grandes obras da construção civil em São Paulo como o Elevado Costa e Silva, conhecido como Minhocão (que liga a região central à zona leste da cidade), o grande Conjunto Habitacional de Itaquera, a ampliação da Avenida Faria Lima e Águas Espraiadas, dentre outros. E como não lembrar ao ver esses empreendimentos, o bordão de uma de suas campanhas incitando justamente seus feitos: Foi Maluf que fez!

O quadro 5 (p.74) além de informar os empreendimentos do PROVER realizados por sua gestão e de seu sucessor Celso Pitta, informa também as empreiteiras responsáveis pela construção dessas obras, onde podemos perceber a notável presença de grandes empresas desse ramo.

Para Silva (op, cit)

Com a nomeação deste empresário e representantes dos agentes privados dos setores da construção civil e imobiliário o diálogo entre o poder executivo e os movimentos sociais que defendem o direito à moradia ficou anda mais difícil, uma vez que este empresário foi indicado para a pasta da Secretaria da Habitação para acelerar as obras de verticalização de favelas construídas por empreiteiras, como previa o programa de governo. (p.32)

Ainda de acordo com o mesmo autor, o executivo paulistano solicita ao Tribunal de Contas do Município que exigisse um levantamento e um relatório sobre o destino das verbas já repassadas aos mutirões, alegando irregularidades com os recursos públicos investidos com o programa Isso ocasionou a suspensão dos repasses, e por conseqüência, a paralisação de diversos mutirões.

2.3 A política de provisão de habit ação na administ ração de Paulo Maluf e Celso Pitta.

Após esses fatos, Paulo Maluf e sua equipe encomendam à FIPE (Fundação Instituto de Pesquisas Econômicas) entre os anos de 1993 e 1994, um estudo sobre as características das 
favelas em São Paulo. O objetivo maior da Prefeitura era de posse dos resultados legitimar a nova política de habitação que seria implantada. Diversos autores apresentam resumo comentado da referida pesquisa (Felipe, 1995), (Pereira, 2001), (Silva, 2003), (Rodrigues, 2006), entre outros. Para nós, importa saber que a pesquisa contabilizou 1.901.892 habitantes morando em 378.863 domicílios $^{75}$.

Abaixo relacionamos algumas das estratégias da nova política habitacional76:

$\checkmark$ Concentração de todos os recursos do Município direcionados aos programas habitacionais em um único Fundo.

$\checkmark$ Democratização e transparência dos procedimentos e processos decisórios, com maior controle e destinação dos recursos do Fundo através da criação do Conselho Municipal de Habitação.

$\checkmark$ Estabelecimento de critérios públicos de seleção de famílias, quer de forma individual, quer via associações.

$\checkmark$ Incentivo à iniciativa privada no sentido de promover programas habitacionais complementares.

$\checkmark$ Estimular a pesquisa e o desenvolvimento tecnológico objetivando novas técnicas de produção de moradia.

$\checkmark$ Priorização do acesso à habitação para a população de baixa renda.

$\checkmark$ Emprego de formas altemativas de produção e acesso à moradia, incluindo: a alternativa de "Leasing" (locação com opção de compra), locação social, além da comercialização convencional (venda de unidades).

$\checkmark$ Financiamento individual ou em condomínio para construção por mutirão/autoconstrução ou aquisição de casa pronta no mercado.

$\checkmark$ Estabelecimento de uma política de subsídios, de caráter pessoal.

$\checkmark$ Comercialização das unidades habitacionais com instrumentos que juridicamente garantam, de fato, o direito à propriedade adquirida, dando segurança necessária às famílias de todos os programas habitacionais.

$\checkmark$ Atuação da Secretaria da Habitação em parceria com a Iniciativa Privada. Constituindo empresa de capital misto, em que se antecipam os recursos financeiros através da emissão de debêntures, ou pelo aporte de recursos das

\footnotetext{
75 Cabe questionar se os levantamentos já realizados à época no município de São Paulo sobre a população favelada não eram suficientes para a implantação da política em questão. Ou seja, cientes do imenso déficit habitacional da cidade de São Paulo, Paulo Malưf não tinha mesmo no início de seu governo a intenção de liquidar tal déficit, mas sim mitigá-lo. 0 que significa dizer que tal pesquisa não precisava ter sido feita.

${ }^{76}$ Retirados do Diário Oficial do Município de 05/01/1995. Suplemento especial.
} 
próprias empresas privadas. Incluem-se, também, nesse contexto, as Operações Interligadas.

Fazia parte das diretrizes do novo programa dentre outras, a manutenção das famílias no próprio local da favela, através de projetos de urbanização e verticalização delas, ou se inviável, promover programas habitacionais no sentido de manter as famílias na mesma região onde já moravam. Já as diretrizes para a implantação de novos conjuntos habitacionais, diziam que era priorizada a utilização de terrenos que fossem remanescentes de conjuntos habitacionais; adquiridos com recursos do FGTS ou em estoque na COHAB-SP ou em HABI; remanescentes de desapropriações de obras públicas; com disponibilidade de infra-estrutura ou passíveis de extensão de redes e localizados em regiões objeto de intervenção urbana que atingissem favelas.

É nesse contexto que o empreendimento do PROVER Parque Continental, foi edificado na mesma área onde está situado o Mutirão Estrela-Guia.

Através da lei de no 11.632, a gestão de Maluf fez uma série de ajustes necessários nas estruturas dos órgãos responsáveis pela implementação da política de habitação. Dentre eles, extinguiu o FUNAPS repassando seus ativos e passivos para o Fundo Municipal de Habitação recém instituído e a COHAB passa a ser o órgão operador desse fundo.

2.4 O PROVER (Programa de Verticalização de Favelas).

Apresentaremos a seguir os aspectos do referido programa que mais interessam à nossa análise: suas diretrizes, fontes de financiamento, caracterização, localização dos empreendimentos, e seus custos. Para abordagem mais completa sobre esse programa remeto 0 leitor à Silva (2003).

O PROVER consistia basicamente na substituição das moradias existentes em favelas por unidades habitacionais novas, construídas em conjuntos verticalizados nelas próprias. Quando essa intervenção não era possível no próprio, a população demandante era realocada para outros empreendimentos próximos a área de suas residências.

Em Krahenbuhl (1996), encontramos os critérios previstos para escolha das favelas a serem atendidas:

$\checkmark$ Favelas localizadas em áreas públicas.

$\checkmark$ Favelas com maior nível de adensamento por $\mathrm{m}^{2}$. 
$\checkmark$ Locais onde os habitantes já haviam consolidado sua ocupação.

$\checkmark$ Favelas onde havia grande número de barracos em áreas de risco.

$\checkmark$ Possibilidade de integração com a vizinhança.

$\checkmark$ Favelas que não constituíssem obstáculo para a execução de alguma obra pública.

$\checkmark$ Possibilidade de atendimento da infra-estrutura.

Outras diretrizes propostas para a política de verticalização de favelas em São Paulo de acordo com o mesmo autor eram:

$\checkmark$ Permanência das famílias no local que "escolheram" 77 para morar.

$\checkmark$ Urbanização dos imóveis remanescentes,

$\checkmark$ Previsão de áreas destinadas ao esporte e ao lazer,

$\checkmark$ Sempre que possível, previsão de áreas para construção dos equipamentos sociais e comunitários,

$\checkmark$ Acesso a todos os equipamentos sociais e senviços públicos como saúde, educação, esporte, segurança, etc.

As fontes de financiamento do PROVER não foram exclusivas do tesouro municipal, e um significativo montante de recursos financeiros foi conseguido em parceria da Prefeitura Municipal e do Banco Interamericano de Desenvolvimento (BID), agência de cooperação fundada em 1959, com o objetivo de promover o desenvolvimento econômico e social da América Latina e Caribe. (Forato \& Ribeiro, 2003).

Vejamos os pronunciamentos sobre essa questão:

Diante da escassez de recursos para implementar o programa habitacional da gestão 93/96; o executivo procurou parceiros para colaborar financeiramente com o projeto. Os recursos que faltavam para viabilizar o programa habitacional foram conseguidos junto ao Banco Interamericano de Desenvolvimento (BID) mediante a firmação de um contrato, onde a prefeitura disponibilizaria 50\% dos recursos necessários ao projeto e o BID os outros 50\%. (Silva, op. cit, p.62).

O mesmo nos dizem Marques \& Saraiva: "O programa contou com 250 milhões de dólares, sendo 150 milhões do BID e o restante da Prefeitura" (2005 p.281).

77 Destaque nosso. 
Pereira (2001) discrimina os recursos da seguinte forma:

Os recursos financeiros utilizados para a execução do programa foram oriundos primeiramente do município (recursos orçamentários). Posteriormente, em 1995, a Caixa Econômica Federal destinou $R \$ 70$ milhões para atender 32 projetos do Cingapura, e o BID investiu em 1996 U\$ 150 milhões no programa, em contrapartida de U\$\$100 milhões, para atendimento de 32 mil famílias, atendendo as fases 2 e 4 do programa. (p.78).

Quanto à caracterização dos empreendimentos do PROVER, foi concluído em quatro fases (considerando-se os empreendimentos das administrações de Paulo Maluf e Celso Pitta). Em suas três primeiras fases, são constituídos por uma tipologia de prédios de cinco pavimentos, com quatro apartamentos por andar e divisão interna de dois dormitórios, banheiro, cozinha conjugada com área de senviço e metragem de 45, $88 \mathrm{~m}^{2}$ de área total78. Embora essa caracterização tenha sido a marca do projeto, em sua última fase surgiram empreendimentos com outras tipologias, com blocos de seis pavimentos (Dom Macário e Goiti), sete pavimentos (Real Parque, Autódromo, Raul Seixas, São Francisco, Arpoador e Jardim do Lago) e onze pavimentos Arpoador e Uirapuru, que em virtude da altura possuem também elevadores. Há também empreendimentos com tipologias de um, dois e três dormitórios, como é o caso por exemplo do Parque Continental. Os apartamentos de um dormitório têm área de 37,37 m², e os de três dormitórios têm área de $51,37 \mathrm{~m}^{2}$.

Para implementar o Programa, a Prefeitura dividiu os procedimentos em três etapas. Na primeira etapa ocorria o levantamento das famílias que participariam do projeto, procedimento este que foi chamado de arrolamento. Na segunda etapa, a equipe técnica de engenheiros e arquitetos comparecia nas favelas alvo do Programa para definir em que áreas da favela seriam edificados os blocos de apartamento, além de definir onde seriam os alojamentos provisórios, utilizados como moradia para a população moradora da área em intervenção, até que a obra ficasse pronta. Na terceira parte, dava-se a transferência dos moradores dos alojamentos para os apartamentos prontos.

Esta etapa era precedida por um período de tempo em que os agentes da Secretaria da Habitação do município, principalmente a equipe de Assistência Social, orientava os futuros moradores sobre as normas, regras e sugestões de comportamento e convívio no novo lugar de morar. As peças publicitárias desse Programa tinham vários formatos: cartilhas, cartazes,

78 "Embora a concepção do Projeto Cingapura desse ênfase à produção de unidades habitacionais verticalizadas, em alguns casos a solução foi mista (prédios e urbanização), caso do Conjunto Goitt'. (Santiago, 2001). Ver também estudo específico sobre a favela Goiti (Haddad, 1999). 
folders, jogos, e palestras com temas variados como, por exemplo: Normas de condomínio, Reciclagem, Prevenção contra incêndio, Conservação e manutenção de áreas comuns, Trato com animais, Dicas de economia, dentre outros assuntos; que eram distribuídos entre os moradores na ocasião das reuniões e fixados em lugares de fácil visibilidade.

Quanto à localização dos empreendimentos Felipe (1995) nos diz:

Os projetos do Cingapura em andamento denotam clara intenção de serem "mostrados" à população paulistana e visitante. Na Rodoviária do Tietê, e próximo ao Shopping Center Norte, o Cingapura Zaki Narchi, na Fernão Dias, o Cingapura Parque Novo Mundo; na Imigrantes e próximo ao Shopping Center Plaza Sul, o Cingapura Miguel Stéfano; na Via Anchieta, o Cingapura do Heliópolis, na Marginal do Rio Tietê, o Cingapura da Água Branca e o Cingapura Benfica, na Marginal do Rio Pinheiros, o Cingapura da Vila Nova Jaguaré, na Av.Interlagos, o Cingapura do Autódromo. (p.451).

Vanildo Silva (2003) compartilha da mesma impressão: “ ...já na primeira gestão pública que executou o Cingapura era possível perceber uma tendência a escolher para edificar unidades em favelas que estavam próximas à vias de grande circulação da cidade". (p.63)

O mapa 2 (p. 77 ) que elaboramos a partir de dados colhidos em diversas fontes representam a espacialização dos empreendimentos na malha urbana da cidade de São Paulo e auxiliam também para confirmar essa hipótese. Nas primeiras fases, os empreendimentos apresentaram também combinação de cores fortes, possivelmente para chamar atenção dos transeuntes, turistas e afins. Entretanto, de acordo com 0 autor citado:

Outro aspecto que podemos notar no segundo tipo de conjunto é a ausência de cores chamativas na parte externa dos edifícios. Possivelmente a localização periférica e longe de vias de grande circulação, tenha tirado destes conjuntos o potencial de painéis de propaganda para o prefeito, bem como gerou desvalorização de imóveis em sua vizinhança (p.64).

Para ele, a pressão dos movimentos de moradia questionando sobre a falta de transparência no critério das favelas escolhidas para participar do Programa gerou esse segundo momento, empreendimentos foram então implementados também em áreas periféricas da cidade. O empreendimento do Parque Continental inserese nesse contexto, tendo sido viabilizado na fase quatro do Programa.

Na porção leste do município, há uma concentração de empreendimentos no distrito de São Rafael, e também ocorrência em Itaquera e Artur Alvim. No distrito de Ipiranga, em virtude do gigantismo da favela de Heliópolis há também uma concentração de empreendimentos. Contudo, chamamos novamente atenção para o aspecto já destacado anteriormente: a 
localização dos empreendimentos nas proximidades das grandes vias de circulação da cidade Avenidas Marginais Pinheiros e Tietê: Vila Andrade, Morumbi, Jaguaré, Vila Leopoldina, Pirituba, Freguesia do Ó, Bairro do limão, Casa Verde, Água Branca, Vila Maria, Penha.

No tocante aos custos do programa, é importante salientar que diversos autores debruçaram-se sobre essa questão, chegando à conclusão de que os custos do PROVER ficaram aquém do esperado para uma política de provisão de habitação de interesse social. Essas conclusões encontraram respaldo na investigação de documentos oficiais, declarações na mídia e comparação com outros projetos de habitação, bem como com os valores praticados pela iniciativa privada por $\mathrm{m}^{2}$ no período analisado. As atualizações dos dados apresentados nas diferentes fontes, por nós pesquisadas, não foram possíveis em virtude das limitações dessa investigação. Por tal motivo, reproduzimos as informações contidas em alguns estudos dessa problemática $^{79}$.

Felipe (1995) encontra no Diário Oficial do Município os valores contratados por unidade habitacional para a $2^{a}$ fase do programa, e salienta que este é maior que o valor de $R \$ 7.800$, declarado pela gestão petista, em propaganda eleitoral, referindo-se ao Programa de Produção de Unidades Habitacionais por Mutirão e Auto Gestão. (Cf Tabela 1).

TABELA 1: 2ª FASE DO PROJETO CINGAPURA - LICITAÇÕES

\begin{tabular}{|c|c|c|c|}
\hline FAVELAS & QTDE & $\begin{array}{c}\text { VALOR CONTRATADO } \\
\text { EM REAIS }\end{array}$ & $\begin{array}{c}\text { CUSTO/UNIDADE } \\
\text { EM REAIS }\end{array}$ \\
\hline Lote 1 & 544 & $10.207 .448,26$ & $18.763,70$ \\
\hline Lote 2 & 776 & $14.014 .999,00$ & $8.060,57$ \\
\hline Lote 3 & 1.200 & $20.980 .318,42$ & $17.483,60$ \\
\hline Lote 4 & 1.156 & $19.994 .918,13$ & $17.296,64$ \\
\hline Lote 5 & 1.076 & $20.184 .061,00$ & $18.758,42$ \\
\hline TOTAL GERAL & $\mathbf{4 . 7 5 2}$ & $\mathbf{8 5 . 3 8 1 . 7 4 5 , 0 1}$ & $\mathbf{1 7 . 9 6 7 , 5 4}$ \\
\hline
\end{tabular}

Fonte: Diário Oficial do Município 05/05/1995

Extraído de Felipe (1995, p.450).

A seguir a declaração de Frei Beto:

\footnotetext{
${ }^{79}$ Silva (2003) analisa relevante contribuição sobre a repercussão sobre os valores praticados por esse Programa
} nos diversos segmentos da sociedade civil. 
Enquanto o metro quadrado da área útil custa no Projeto Cingapura U\$\$262,62, na gestão Erundina o metro quadrado custava no Conjunto Habitacional Madre de Deus U\$ 181,00 e no Conjunto Talora, U\$ 133,41. Portanto, o mutirão fazia o metro quadrado por cerca de U\$\$100,00 a menos. (Frei Beto, o Estado de São Paulo, 27/07/1995) ${ }^{80}$.

Silva (op.cit,) comparando os anuários da Fundação SEADE e os documentos de uma das gerenciadoras do Projeto e da Secretaria da Habitação, conclui conforme quadro abaixo, que os valores praticados para o programa de verticalização e urbanização de favelas é maior que os praticados pela iniciativa privada em três anos. Chama a atenção o valor do $\mathrm{m}^{2}$ do PROVER no distrito do Jaguaré, justamente o local em que está situado o empreendimento do Parque Continental.

QUADRO 2: COMPARAÇÃO DOS VALORES DO CUSTO DE PRODUÇÃO DO M² EM REAIS ENTRE O PROVER E A INICIATIVA PRIVADA

\begin{tabular}{|c|c|c|c|c|}
\hline DISTRITO & SEADE 1995* & SEADE 1996* & SEADE 1997* & \multirow{2}{*}{ PROVER $^{* *}$} \\
\hline Jaguaré & 625,95 & 544,36 & 509,06 & $1.013,54$ \\
\hline Penha & 673,25 & 707,41 & 761,36 & 796,60 \\
\hline Vila Carrão & 559,63 & 755,84 & 619,94 & 858,46 \\
\hline Vila Leopoldina & 724,18 & 865,32 & 718,11 & 939,93 \\
\hline São Miguel Paulista & 546,24 & 509,87 & 540,57 & 890,79 \\
\hline
\end{tabular}

Fonte: * Anuários estatísticos Fundação SEADE.

** Tabela de atualização DUCTOR/SEHAB, 2000.

Extraído de Silva $(2003,113)$.

Felipe (op.cit) compara dois empreendimentos similares (das administrações petista e malufista), por suas tipologias (prédios de apartamentos com mesmo número de pavimentos, mesma divisão interna, e metragens aproximadas) e corrobora a consideração de Frei Beto para o Jornal O Estado de São Paulo: de que o custo do $\mathrm{m}^{2}$ do Cingapura é quase o dobro do $\mathrm{m}^{2}$ dos mutirões implantados na gestão de Luiza Erundina. Eis o quadro abaixo:

80 Extraído de Silva (op.cit, p.109). 
QUADRO 3: COMPARAÇÃO ENTRE PROVER E MUTIRÃO

\begin{tabular}{|c|c|c|}
\hline & PROVER HELIÓPOLIS & MUTIRÃO CASARÃO \\
\hline QTDE & 600 aptos & 182 aptos \\
\hline ÁREA & $30,82 \mathrm{~m}^{2}$ & $31,80 \mathrm{~m}^{2}$ \\
\hline TIPO & 5 pavimentos em "L" & 5 pavimentos em "lâmina" \\
\hline CUSTO/APTO & $\mathrm{R} \$ 15.419,76$ & $\mathrm{R} \$ 10.276,93$ \\
\hline CUSTO/M² & $\mathrm{R} \$ 374,27$ & $\mathrm{R} \$ 197,63$ \\
\hline
\end{tabular}

Extraído de Felipe (1995 p.450).

Rodrigues (2006) utilizando-se do mesmo raciocínio do autor supra citado, compara o Mutirão Campanha Gaúcha e o Conjunto Habitacional Imigrantes (empreendimento do PROVER) - ambos objetos de sua análise, para chegar à mesma conclusão: de que os mutirões foram mais baratos do que os conjuntos habitacionais do programa de habitação de Paulo Maluf e Celso Pitta.

Em oposição às considerações anteriores podemos citar Pereira (2001). Vejamos:

O custo deste conjunto habitacional ${ }^{81}$ ( $\mathrm{R} \$ 23.529$ por unidade), considerando-se a complexidade de implantação, encontra-se numa faixa compatível com os custos de outros conjuntos habitacionais, como pode ser visto pelo quadro abaixo, onde são apresentados os custos de conjuntos habitacionais promovidos por outros modos de provisão:

${ }^{81}$ Referindo-se ao Conjunto Habitacional Zaki Narchi (objeto de sua análise). 
QUADRO 4: CUSTO DAS UNIDADES HABITACIONAIS DOS MODOS DE PROVISÃO DE PROVEDORAS PÚBLICAS EM REAIS, POR UNIDADE.

\begin{tabular}{|c|c|c|c|}
\hline $\begin{array}{l}\text { MUTIRÃO CDHU } \\
\text { ÁREA } 52,71 \mathrm{~m}^{2}\end{array}$ & $\begin{array}{c}\text { MUTIRÃO } \\
\text { COHAB/SP } \\
\text { ÁREA } 79,60 \mathrm{~m}^{2}\end{array}$ & $\begin{array}{c}\text { EMPREITADA } \\
\text { GLOBAL - CDHU } \\
\text { ÁREA } 45,00 \mathrm{~m}^{2}\end{array}$ & $\begin{array}{c}\text { PLANO } \\
\text { EMPRESÁRIO } \\
\text { COHAB/SP } \\
\text { ÁREA } 43,00 \mathrm{~m}^{2}\end{array}$ \\
\hline $\begin{array}{c}12.900 \mathrm{~s} / \\
\text { infraestrutura }\end{array}$ & $\begin{array}{c}7.424 \\
\text { s/infraestrutura }\end{array}$ & 19.628 sobrado & $\begin{array}{c}22.417 \\
\text { s/infraestrutura }\end{array}$ \\
\hline $\begin{array}{c}16.000 \\
\text { c/infraestrutura }\end{array}$ & ----------------- & $\begin{array}{c}23.130 \\
\text { apartamento }\end{array}$ & $\begin{array}{c}25.631 \\
\text { c/infraestrutura }\end{array}$ \\
\hline
\end{tabular}

Fonte: Werna et al,2001.

Extraído de Pereira (op.cit,p.146).

Diferente dos outros pesquisadores, Pereira não indica em qual fonte aparece o valor de $\mathrm{R} \$ 23.529$. Além disso, parecenos que a referida autora não ponderou que as demandas dos programas por ela citados não eram compostas exclusivamente de população oriunda de favelas, como foi o caso do PROVER. E que o valor da unidade habitacional do conjunto em questão está acima da maioria dos valores que apresenta.

Quanto aos números do Programa, o relatório da Prefeitura Municipal atualizado em 2000, contabiliza 14.308 unidades, Marques \& Saraiva (2005) apontam um número de 13.295 unidades habitacionais. Pereira (op.cit) trabalha com a cifra de 13.456, sem considerar dois empreendimentos licitados em 2001 (época em que sua pesquisa foi realizada): City Jaraguá e Nicarágua/Vila da Paz. Isso significa dizer que o número de empreendimentos talvez ultrapasse os apresentados acima, sem, no entanto, se aproximar do que previam as administrações Paulo Maluf (20 mil unidades), e Celso Pitta (60 mil unidades).

Assim como outros programas de provisão de habitação, o PROVER também tem uma questão fundiária complexa Isso porque a regularização das áreas encontra sempre obstáculos que dizem respeito à desapropriação, desafetação e que depende inclusive da origem das áreas (privadas ou públicas). Soma-se a isso, a forma jurídica escolhida para regularizar esses empreendimentos, decisão que pode variar conforme a administração municipal. № caso do PROVER, o processo de regularização inicialmente estava sendo feito pela própria SEHAB 
através da HAB|82. Atualmente, no entanto, está sob ingerência da COHAB (administradora do Fundo Municipal de Habitação).

Aos moradores do PROVER, foi conferido à entrega dos apartamentos um Termo de Permissão de Uso à Título Precário e Oneroso que significa, em linhas gerais, a permissão para o morador usar o apartamento para fins específicos de moradia, não podendo ceder, vender, alugar, emprestar ou transferir o imóvel. De caráter oneroso, o morador, nesse caso designado permissionário, fica comprometido a retribuir o uso do imóvel mensalmente aos cofres do município, no valor fixado pela Prefeitura Municipal. Significa dizer que, o morador dos empreendimentos PROVER é um permissionário, e em hipótese nenhuma proprietário do bem, este conferido à Prefeitura, designada permitente. A adoção desse instrumento jurídico gerou em diversos empreendimentos do PROVER uma série de insatisfações e conseqüente processo de inadimplência do pagamento da Permissão. Atualmente, as unidades habitacionais estão sendo comercializadas pela COHAB com base na capacidade financeira dos moradores, com contrato de 25 anos, sendo o montante pago até o momento da proposta de comercialização para os adimplentes deduzido do valor total do imóvel. Veremos adiante, além de outros aspectos, a repercussão da proposta de comercialização dos apartamentos do empreendimento do Parque Continental.

No quadro 5, temos uma síntese do Programa de Verticalização de Favelas (PROVER) no que diz respeito as fases de implantação do Programa, distritos municipais em que foram construídos os edifícios, número de unidades habitacionais por empreendimento e empreiteiras contratadas.

82 Superintendência de Habitação Popular da Secretaria de Habitação e Desenvolvimento Urbano da Prefeitura do Município de São Paulo. 
QUADRO 5: PROGRAMA DE VERTICALIZAÇÃO DE FAVELAS (PROVER)

\begin{tabular}{|c|c|c|c|c|}
\hline $\begin{array}{c}\text { FASE DO } \\
\text { PROGRAMA }\end{array}$ & EMPREENDIMENTO & $\begin{array}{l}\text { DISTRITOS } \\
\text { MUNICIPAIS }\end{array}$ & $\begin{array}{c}\text { UNIDADES } \\
\text { HABITACIONAIS }\end{array}$ & EMPREITEIRA \\
\hline 1 & Parque Novo Mundo & Vila Maria & 620 & Schahin \\
\hline 1 & Zaki Narchi & Santana & 700 & Schahin \\
\hline 1 & Água Branca & Barra Funda & 180 & OAS \\
\hline 1 & Jardim Maninos & Santana & 160 & OAS \\
\hline 1 & Nova Jaguaré & Jaguaré & 260 (2 setores) & OAS \\
\hline 1 & $\begin{array}{c}\text { Real Parque /Luiz de } \\
\text { Bragança }\end{array}$ & Morumbi & 84 & OAS \\
\hline 1 & Autódromo & $\begin{array}{l}\text { Campo } \\
\text { Grande }\end{array}$ & 244 & Schahin \\
\hline 1 & Campo Grande & $\begin{array}{l}\text { Campo } \\
\text { Grande }\end{array}$ & 100 & Schahin \\
\hline 1 & Imigrantes & Ipiranga & 160 (2 setores) & Schahin \\
\hline 1 & Miguel Stéfano & Saúde & 80 & Schahin \\
\hline 1 & Santo Antônio/ Peinha & Vila Andrade & 80 & Schahin \\
\hline \multicolumn{3}{|c|}{ Sub- Total da Fase I } & \multicolumn{2}{|c|}{2668} \\
\hline 2 & Dom Macário & Sacomã & 96 & Construbase \\
\hline 2 & $\begin{array}{c}\text { Santo Antônio/Parque } \\
\text { Otero }\end{array}$ & $\begin{array}{l}\text { Jardim São } \\
\text { Luiz }\end{array}$ & 500 (4setores) & Construbase \\
\hline 2 & Heliópolis/Gleba L & Ipiranga & 600 & CBPO \\
\hline 2 & $\begin{array}{c}\text { José Paulino dos } \\
\text { Santos/ São Judas (1a } \\
\text { fase) }\end{array}$ & Mooca & 180 & CBPO \\
\hline 2 & Chaparral & Penha & 280 & Camargo Côrrea \\
\hline 2 & Chaparral/Tiquatira & Penha & 200 & Camargo Côrrea \\
\hline 2 & Edu Chaves & Jaçanã & 400 & Camargo Côrrea \\
\hline 2 & Edu Chaves/Vila Nilo & Jaçanã & 260 & Camargo Côrrea \\
\hline 2 & Haia do Carrão & Aricanduva & 240 & Camargo Côrrea \\
\hline 2 & $\begin{array}{l}\text { São Francisco I - } \\
\text { Morro das Pedras }\end{array}$ & São Rafael & 80 & Construbase \\
\hline
\end{tabular}




\begin{tabular}{|c|c|c|c|c|}
\hline 2 & $\begin{array}{c}\text { São Francisco II- } \\
\text { Benfica }\end{array}$ & São Rafael & 80 & Construbase \\
\hline 2 & $\begin{array}{l}\text { São Francisco III- } \\
\text { Coruja do Campo }\end{array}$ & São Rafael & 40 & Construbase \\
\hline 2 & $\begin{array}{c}\text { São Francisco IV- } \\
\text { Hidrosfera }\end{array}$ & São Rafael & 196 & Construbase \\
\hline 2 & $\begin{array}{c}\text { São Francisco V- Área } \\
5\end{array}$ & São Rafael & 340 & Construbase \\
\hline 2 & Raul Seixas & Itaquera & 112 & Construbase \\
\hline 2 & São Jorge/ Arpoador & $\begin{array}{l}\text { Raposo } \\
\text { Tavares }\end{array}$ & 562 & OAS \\
\hline 2 & Uirapuru & $\begin{array}{l}\text { Raposo } \\
\text { Tavares }\end{array}$ & 418 & OAS \\
\hline \multicolumn{3}{|c|}{ Sub- Total da Fase 2} & \multicolumn{2}{|r|}{4584} \\
\hline 3 & Jardim do Lago & $\begin{array}{l}\text { Raposo } \\
\text { Tavares }\end{array}$ & 156 & OAS/Corrêa/Construbase \\
\hline 3 & $\begin{array}{c}\text { Real Parque/ Luiz de } \\
\text { Bragança }\end{array}$ & Morumbi & 285 & OAS/Corrêa/Construbase \\
\hline 3 & Lidiane - Vila Nova & $\begin{array}{c}\text { Freguesia do } \\
\text { Ó }\end{array}$ & 260 & Planova \\
\hline 3 & Piqueri & Pirituba & 160 & Planova \\
\hline 3 & Samarita & Casa Verde & 280 & Planova \\
\hline 3 & Trivelato & $\begin{array}{c}\text { Freguesia do } \\
\text { Ó }\end{array}$ & 300 & Planova \\
\hline 3 & Chácara Bela Vista & Vila Maria & 960 & CBPO/Schahin/Constran \\
\hline 3 & Cidade A. E. Carvalho & São Rafael & 320 & H.Guedes/L.Castelo/Blokos \\
\hline 3 & Goiti & Itaquera & 296 & H.Guedes/L.Castelo/Blokos \\
\hline 3 & $\begin{array}{c}\text { Jardim Maraial/ Jardim } \\
\text { Nordeste }\end{array}$ & Artur Alvim & 180 & H.Guedes/L.Castelo/Blokos \\
\hline \multicolumn{3}{|c|}{ Sub- Total da Fase 3} & \multicolumn{2}{|r|}{3197} \\
\hline 4 & Heliópolis/Gleba A & Ipiranga & 473 & OAS/Construbase \\
\hline 4 & $\begin{array}{c}\text { José Paulino dos } \\
\text { Santos } 2\end{array}$ & Mooca & 640 & OAS/Construbase \\
\hline 4 & Nicarágua /Vila da Paz & Cidade Dutra & 728 & Santa Bárbara \\
\hline
\end{tabular}




\begin{tabular}{|c|c|c|c|c|}
\hline 4 & Madeirit/Votorantim & $\begin{array}{c}\text { Vila } \\
\text { Leopoldina }\end{array}$ & 400 & H.Guedes/L.Castelo/Blokos \\
\hline 4 & Parque Continental & Jaguaré & 420 & H.Guedes/L.Castelo/Blokos \\
\hline 4 & São Domingos & Rio Pequeno & 332 (4 setores) & H.Guedes/L.Castelo/Blokos \\
\hline 4 & Morro da Esperança & Cachoeirinha & 380 & CBPO/Schahin/Q.Galvão \\
\hline 4 & City Jaraguá/Setor3 & Jaraguá & 486 & CBPO/Schahin/Q.Galvão \\
\hline & Sub- Total da Fase 4 & & 3859 \\
\hline & & & 14308 \\
\hline
\end{tabular}

Fonte: Prefeitura do Município de São Paulo, 2000.

Secretaria da Habitação e Desenvolvimento Urbano - SEHAB

Org: Patrícia Maria de Jesus 


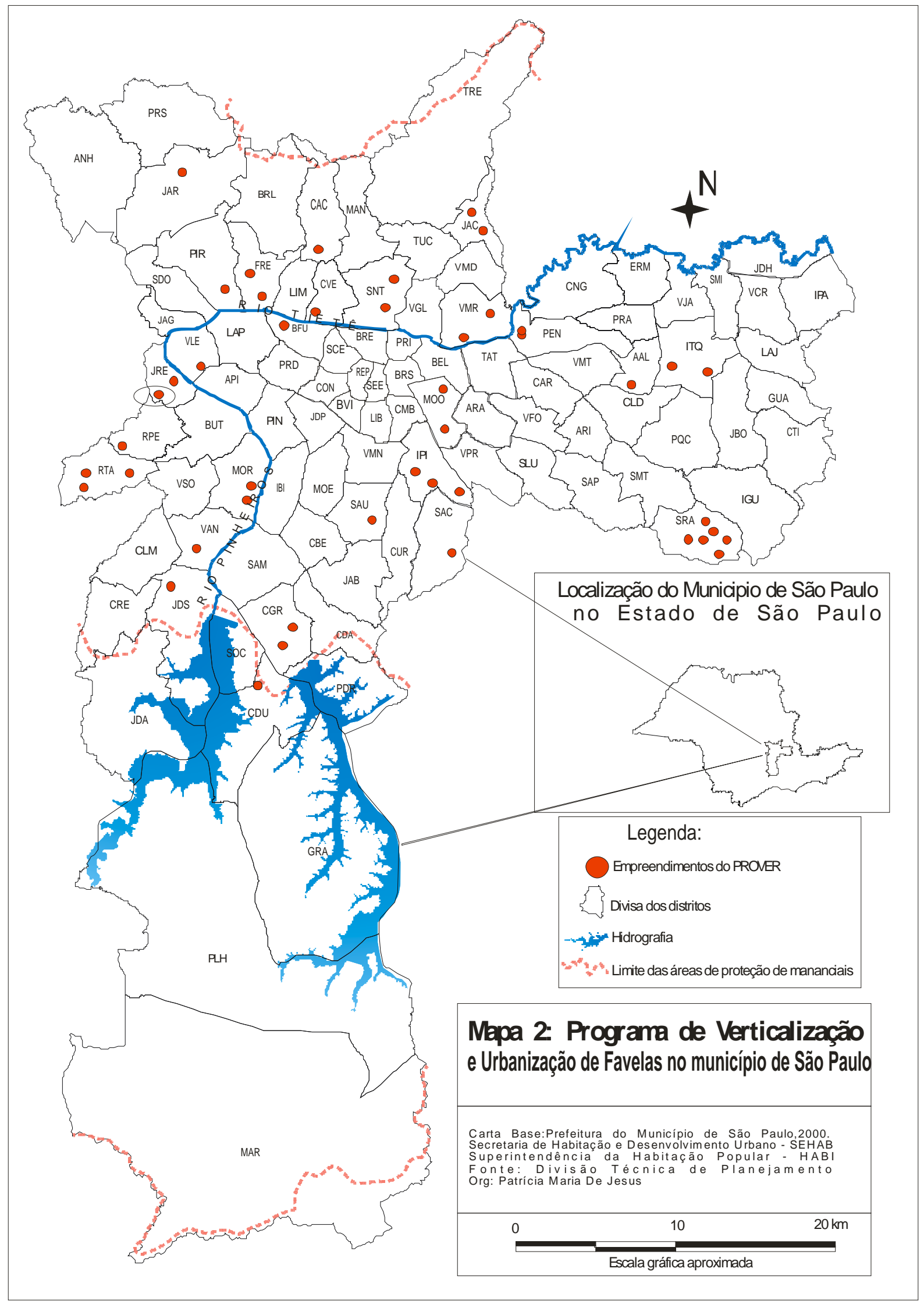




\subsection{Operações Interligadas.}

Os administradores Paulo Maluf (1993 a 1996) e Celso Pitta (1997 a 2000) utilizaram-se do instrumento conhecido como Operações Interligadas para viabilizar também moradias populares no município. Em linhas gerais, as Operações Interligadas legitimavam as alterações no zoneamento do município beneficiando os agentes construtores privados, e esses por sua vez, viabilizavam recursos para produção de habitações populares, além de áreas destinadas ao sistema viário, equipamentos públicos e lazer.

De acordo com Marques \& Saraiva (2005) as Operações Interligadas são uma versão posterior da Lei de Desfavelamento, criada no governo de Olavo Setúbal83.

Uma vez que a principal política de habitação dessas duas administrações era o PROVER (Programa de Verticalização e Urbanização de Favelas), as Operaçães Interligadas foram consideradas "Projetos Especiais de Habitação". É necessário frisar que na área de nossa pesquisa, a implantação dos edifícios das Operaçães Interligadas aconteceu anteriormente à implantação dos edifícios PROVER, todavia, no âmbito do programa de governo dos referidos administradores, elas ocorreram paralelamente.

De acordo com dados da Secretaria de Habitação e Desenvolvimento Urbano da Prefeitura do Município de São Paulo (2000), o número de unidades habitacionais construídas por meio desse instrumento é de 1814. No entanto, autores como LO.Silva (2006) demonstram o número de 3.348 unidades de habitações de interesse social viabilizadas através das Operações Interligadas.

De acordo com o mesmo autor no ano de 1998, houve por parte do poder judiciário, o acolhimento de uma ação direta de inconstitucionalidade referente à aplicação desse instrumento junto ao Ministério Público. As denúncias de uma série de irregularidades culminaram em 2001 numa Comissão Parlamentar de Inquérito para apurá-las.

No decorrer da CPI, não foram apuradas somente irregularidades ocorridas no tocante à execução das Operações Interligadas (particulares beneficiados), mas também, no que refere-se às habitações de interesse social. Dentre elas:

${ }^{83}$ A Lei de Desfavelamento serviu pouco ao objetivo de produção de moradias para os favelados removidos; favoreceu a "limpeza social" dos bairros mais ricos e os negócios imobiliários, por meio de alterações pontuais na Lei de Zoneamento e no Código de Obras. Foi depois adaptada e transformou-se na Lei das Interligadas (Lei $n^{\circ}$ 11.773/95), perdendo a vinculação mais direta com a remoção de favelas. (2005, p.274). Ver página 32 desse trabalho também baseada nos autores citados. 
$\checkmark$ Construções inacabas das habitações (ausência de estacionamento, antenas, muros, etc); como o ocorrido nos Conjuntos Habitacionais Texima, Boa Esperança e Chácara das Flores;

$\checkmark$ Irregularidades nas metragens (objeto de contrapartida das Operações Interligadas), pois algumas das habitações de interesse social foram entregues em desacordo com o estipulado nos termos de compromisso. Isso ao mesmo tempo em que onerou a população demandante de moradia, gerou lucros aos empreendedores;

$\checkmark$ Irregularidades na ocupação das habitações, pois se constatou que muitas habitações foram "reservadas" a pessoas não oriundas de favelas, como advogados e guardas civis metropolitanos ${ }^{84}$.

QUADRO 6: OPERAÇÕES INTERLIGADAS

\begin{tabular}{|c|c|c|}
\hline EMPREENDIMENTO & $\begin{array}{c}\text { DISTRITOS } \\
\text { MUNICIPAIS }\end{array}$ & $\begin{array}{c}\text { UNIDADES } \\
\text { HABITACIONAIS }\end{array}$ \\
\hline Texima & Jardim Helena & 257 \\
\hline Munck & Raposo Tavares & 79 \\
\hline Sapé & Rio Pequeno & 460 \\
\hline Jardim Olinda & Campo Limpo & 35 \\
\hline Jardim Celeste & Sacomã & 117 \\
\hline Jardim São Francisco & São Rafael & 44 \\
\hline João Nery - Chácara das Flores & Vila Nova Curuçá & 560 \\
\hline Recanto dos Humildes & Pirituba & 136 \\
\hline Água Branca & Barra Funda & 6 \\
\hline Parque Continental & Jaguaré & 120 \\
\hline Total Operações Interligadas & \multicolumn{2}{|c}{1814} \\
\hline
\end{tabular}

Fonte: Prefeitura do Município de São Paulo, 2000.

Secretaria da Habitação e Desenvolvimento Urbano - SEHAB

Org: Patrícia Maria de Jesus

${ }^{84}$ Ressalte-se que tais irregularidades não dizem respeito especificamente ao empreendimento do Parque Continental, mas à totalidade dos conjuntos habitacionais construídos a título de contrapartida das Operações Interligadas. Tais dados baseiam-se no Relatório Final da CPI tornado público em 2002. 


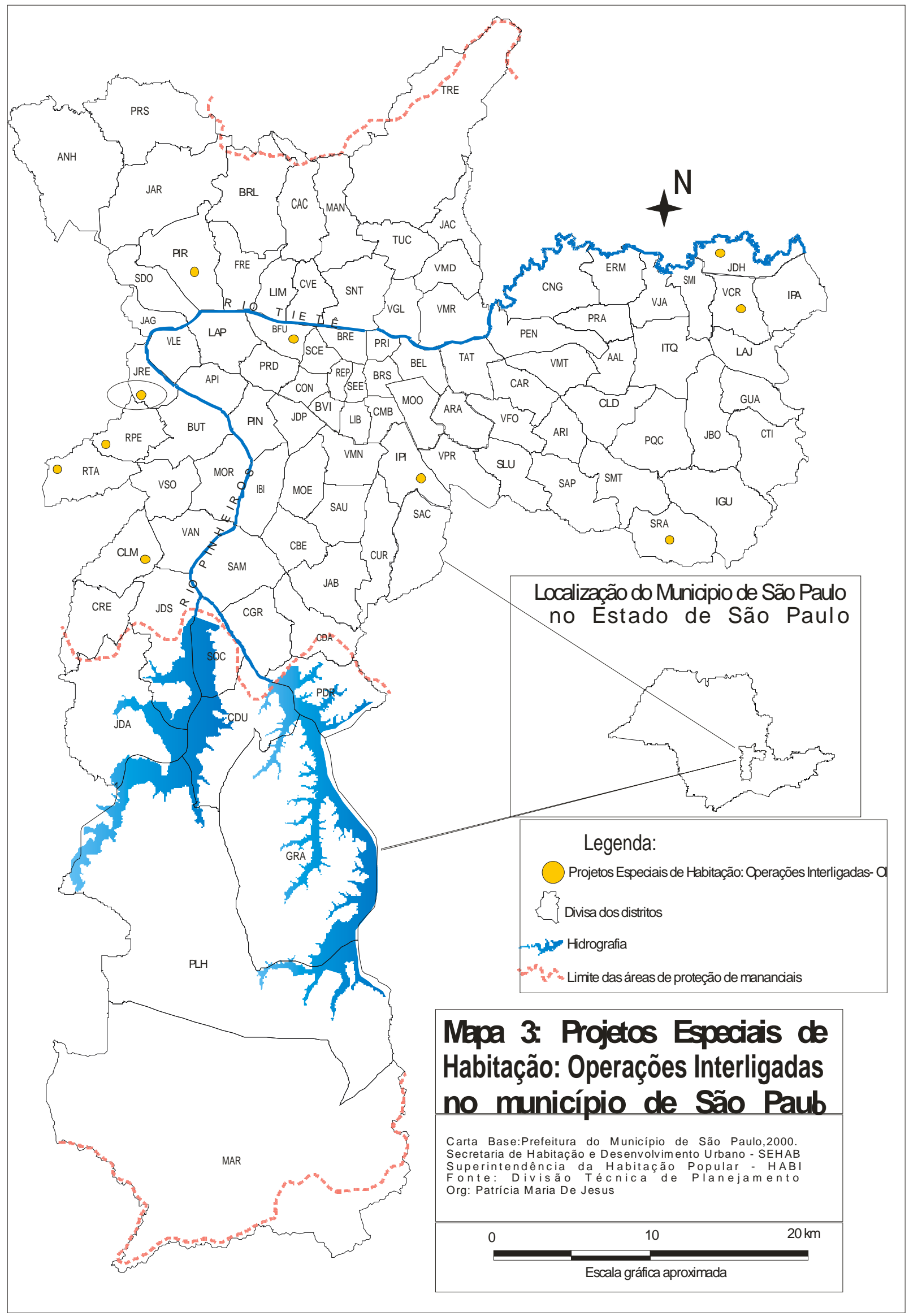


2.6 A implantação do Conjunto Habitacional Parque Continental.

2.6.1 Não é Cingapura, é CDHU!

No ano de 1996, na mesma gleba do Mutirão Estrela Guia, foram edificados seis prédios de cinco pavimentos, com quatro apartamentos de dois dormitórios por pavimento, totalizando 120 unidades habitacionais. Como esse projeto foi implantado paralelamente aos empreendimentos do PROVER, o trabalho de ação social realizado pela equipe de Assistência Social da Prefeitura Municipal era exatamente o mesmo daquele realizado com moradores das favelas sob intervenção do Projeto. Embora o padrão arquitetônico externo dos edifícios fosse parecido, (efetivamente eram diferentes dos empreendimentos do Programa), e a fonte de recursos fosse outra, a apresentação desse empreendimento para com a população selecionada era exatamente a mesma dispensada às pessoas contempladas pelo PROVER. Cumpre salientar, no entanto, que a demanda dos empreendimentos de habitação popular das Operações Interligadas era a mesma do PROVER. Em outras palavras, a Prefeitura sabia exatamente do que se tratavam as Operações Interligadas, o mesmo não se pode dizer da população prestes a ser transferida para o empreendimento. Quanto à procedência da demanda, foram transferidas para o empreendimento todas as famílias residentes em área de risco do núcleo de favela da Vila Sol, no distrito do Rio Pequeno. A área em questão tratava-se de um córrego, motivo pelo qual as famílias não precisaram morar provisoriamente em alojamentos, uma vez que havia o terreno disponível junto ao Mutirão Estrela Guia em distrito vizinho ao Rio Pequeno e, também, porque em fase posterior, a intervenção do PROVER na referida favela canalizaria o córrego, para a abertura de uma via asfaltada, o que impossibilitaria a permanência dessas famílias no mesmo local de moradia.

Tendo sido os primeiros prédios de apartamentos edificados na área em questão, até o presente momento, a situação fundiária dos empreendimentos realizados via Operações Interligadas no Parque Continental é desconhecida e ainda mais complexa que a situação dos prédios viabilizados pelo PROVER na mesma área. Isso provavelmente ocorra porque as Operações Interligadas foram apuradas por uma Comissão Parlamentar de Inquérito no ano de 2002, alvo de inúmeras irregularidades. Na prática, isso significa que nos seis edifícios das Operações Interligadas, nenhum morador possui qualquer tipo de instrumento jurídico que lhe confira direitos sobre o imóvel: permissão de uso, concessão de direito real de uso, contrato, ou qualquer similar. Os mesmos somente pagam as taxas relativas ao consumo de serviços: água, 
luz, telefone, condomínio (quando há). Do ponto de vista das diferenças: tempo de implantação, situação fundiária, e padrão arquitetônico diferente; alguns moradores ensaiam uma explicação: "Não é Cingapura, é CDHU"! Difícil desvendar o que há por trás desses discursos, arriscamo-nos a pensar que se sentem "privilegiados" por morarem em prédios cujo padrão arquitetônico difira dos outros empreendimentos do PROVER, tão facilmente reconhecíveis na cidade, ainda que sejam muito parecidos, e no empreendimento do Parque Continental tenham exatamente as mesmas cores externas. Talvez imaginem que não serão estigmatizados, como muitas vezes o são moradores de conjuntos habitacionais promovidos pelo poder público, mais ainda o Projeto Cingapura, específico para demandas de favelas, mesmo que também eles (os moradores) dos empreendimentos das Operações Interligadas sejam oriundos de áreas favelizadas, pois a favela, como veremos nas falas dos moradores, mais adiante nesse capítulo, "já era, ficou pra trás".

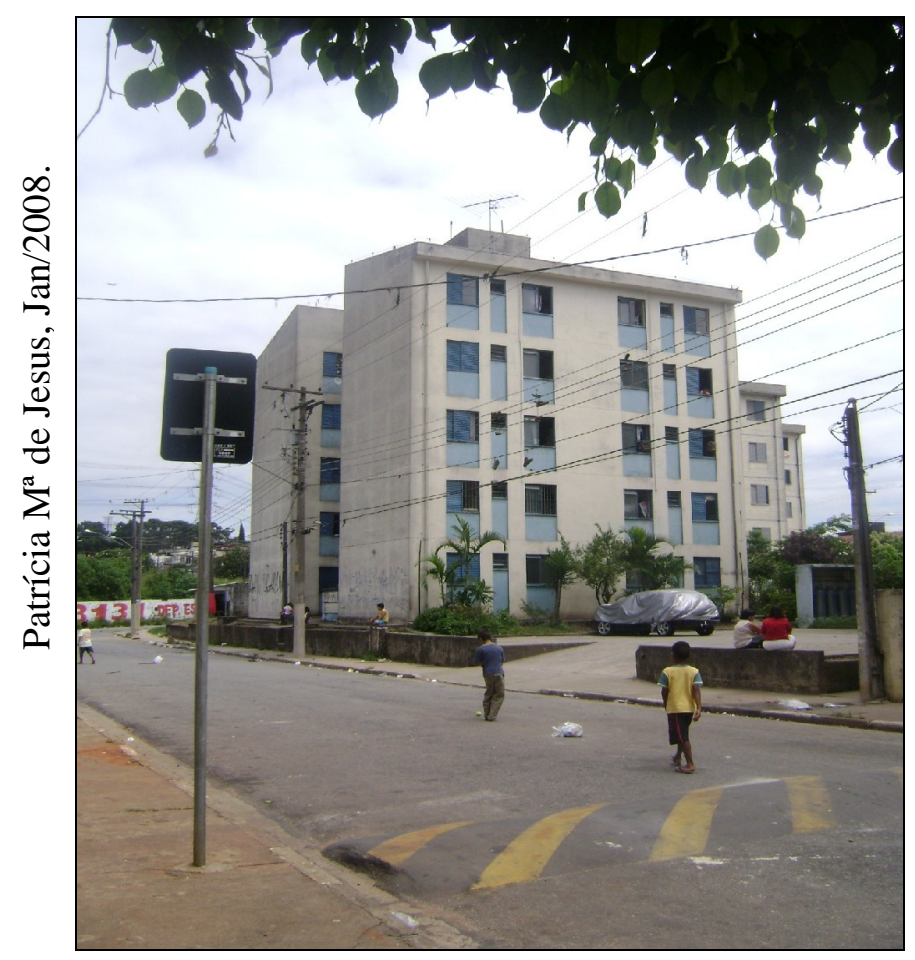

Foto 2: Edifícios das Operações Interligadas (observar a tipologia diferente dos edifícios PROVER) e crianças brincando na rua Quica D’Água. 
2.7 Os prédios Cingapura.

São 21 prédios de apartamentos com cinco pavimentos, com quatro apartamentos por andar, totalizando 420 unidades habitacionais, distribuídas em: três blocos de três dormitórios (60 unidades), 15 blocos de dois dormitórios (300 unidades) e três blocos de um dormitório (60 unidades).

De acordo com relatório da SEHAB, esse empreendimento atendeu saldo de demanda de outros empreendimentos:

QUADRO 7: FAVELAS ATENDIDAS PELO PROVER PARQUE CONTINENTAL

\begin{tabular}{|c|c|c|}
\hline FAVELA & FAMÍLIAS ARROLADAS & $\begin{array}{c}\text { FAMÍLIAS } \\
\text { ATENDIDAS }\end{array}$ \\
\hline Madeirit/Votorantim & 991 & 291 \\
\hline São Domingos/Camarazal & 941 & 129 \\
\hline
\end{tabular}

Fonte: Prefeitura do Município de São Paulo, 2000.

Secretaria da Habitação e Desenvolvimento Urbano - SEHAB

Org: Patrícia Maria de Jesus

As famílias remanescentes (diferença entre as famílias arroladas e as atendidas) foram atendidas nos empreendimentos PROVER nos próprios núcleos das favelas MadeiritVotorantin, e São Domingos/Camarazal. Não obtivemos dados exatos, mas é sabido através de conversas com os moradores da área, que parte da população morou provisoriamente em alojamentos construídos no distrito de Raposo Tavares, bairro de João XXIII, na porção oeste do município.

Para a edificação dos prédios foram abertas na gleba mais duas vias asfaltadas e, outras melhorias como; iluminação pública, asfalto e sinalização, só foram conseguidas na área após a conclusão do empreendimento no ano de 1999. Do ponto de vista dos equipamentos comunitários, foram construídos uma quadra de futebol, um pequeno playground e um centro comunitário. Como à época da construção do Mutirão Estrela Guia o canteiro de obras foi reaproveitado e transformado em Centro Comunitário, a área contou durante algum tempo com dois desses equipamentos, não fosse a ocupação deste último, por diversas famílias, que o dividindo fizeram inúmeras casas mal-acabadas de um ou dois cômodos. 
QUADRO 8: PERÍODO DE OCUPAÇÃO DOS BLOCOS

\begin{tabular}{|c|c|c|}
\hline \multirow{2}{*}{ PROJETO } & DATA DE OCUPAÇÃO & BLOCOS \\
\hline \multirow{2}{*}{$\begin{array}{c}\text { Operações } \\
\text { Interligadas }\end{array}$} & $\mathrm{A} 1$ e A2 & Novembro/1996 \\
\cline { 2 - 3 } & $\mathrm{B} 2, \mathrm{~B} 3$ e B4 & Dezembro/1998 \\
\hline \multirow{2}{*}{ PROVER } & $\mathrm{B} 1$ & Março/1999 \\
\cline { 2 - 3 } & 01 a 07 & Maio/1999 \\
\hline
\end{tabular}

Fonte: Prefeitura do Município de São Paulo, 2005.

Secretaria da Habitação e Desenvolvimento Urbano - SEHAB

Org: Patrícia Maria de Jesus

No sentido de viabilizar a implementação do Programa de Regularização, Recuperação de Créditos e Revitalização do Empreendimento Habitacional Parque Continental, foram realizadas pela SEHAB/HABI diversas ações juntos aos moradores e lideranças dos blocos nos períodos entre junho a setembro de 2005. Dentre essas ações, destacam-se pesquisa censitária, investigação com representantes de blocos, vistorias para avaliação dos aspectos físicos do Conjunto e análise qualitativa. Vale ressaltar que embora os resultados dessas ações tenham sido fundamentais para nossa investigação, eles referem-se somente aos edifícios das Operações Interligadas e do PROVER. O que significa que os dados relativos à população residente nas 100 unidades habitacionais do Mutirão Estrela Guia não foram contemplados na referida pesquisa ${ }^{85}$.

A seguir, um resumo dos principais dados socioeconômicos da população moradora dos edifícios do Conjunto Habitacional Parque Continental 86:

85 Os empreendimentos selecionados para a implementação do Programa de Regularização, Recuperação de Créditos e Revitalização de Empreendimentos foram concebidos nos Programas PROVER, PROCAV e Guarapiranga.

${ }^{86}$ Os dados foram extraídos dos relatórios da pesquisa mencionada. Enfatizamos que há nos relatórios inúmeros outros dados, todavia, selecionamos aqueles pertinentes ao nosso propósito. Após a apresentação dos dados, tecemos comentários quando estes foram considerados necessários. 
2.8 A população residente.

\section{Composição da população.}

Foram cadastrados 1.995 habitantes em 537 familias e 537 unidades habitacionais. ${ }^{87}$ Somadas à população residente nas 100 unidades habitacionais do Mutirão, certamente o número de habitantes do Conjunto Habitacional Parque Continental chega a 2.500 pessoas (se consideramos o número médio de cinco pessoas por família e as pessoas moradoras das construções irregulares).

Sobre a composição da população há uma superioridade do sexo feminino, sendo $52,8 \%$, enquanto a porcentagem do sexo masculino é de $47,2 \%$.

\section{Estrutura etária da população.}

A estrutura etária da população pesquisada caracteriza-se por duas expressivas parcelas de habitantes: crianças de 0 a 14 anos (33,4\%), e o segmento que engloba o período de maior produtividade econômica, pessoas entre 22 e 49 anos (43,8\%), destacando-se a faixa de 30 a 49 anos com $29,3 \%$ dos moradores com esse perfil. A média de idade é de 24,9 anos, sendo que os habitantes com 50 anos ou mais totalizam $7,6 \%$.

O percentual de crianças, na faixa etária de 0 a 6 anos (equivalente à creche e pré escola) representa $14 \%$ do total de habitantes e a de 7 a 14 anos (que corresponde ao ensino fundamental) atinge $19,4 \%$.

\section{Freqüência à escola}

No tocante à freqüência a escola, mais de dois terços dos moradores com idade entre 0 e 17 anos freqüentam a escola (83,4\%). 99,5\% das crianças na faixa de 7 a 14 anos (idade que corresponde ao ensino regular obrigatório) estão na escola, o que acontece também com $91,2 \%$ dos adolescentes entre 15 e 17 anos. Esse aspecto deve-se certamente ao fato de o empreendimento estar bem senvido de instituições de ensino no seu entorno, quer sejam elas municipais ou estaduais. Por outro lado, dbserva-se ainda que 97 das 139 crianças de 0 a 3 anos, ou seja, 69,8\% não são atendidas por creches. Esse dado subsidia a reivindicação dos moradores no sentido de conseguir a implantação de uma creche nas proximidades do empreendimento.

Inserção da população com 16 anos ou mais no mercado de trabalho

${ }^{87}$ Não foi possível realizar pesquisa em um apartamento de cada um dos seguintes blocos: 9,19 e 21 . 
75,9\% dos entrevistados com 16 anos ou mais fazem parte da População Economicamente Ativa (979 pessoas); das quais destacam-se 31,7\% de empregados registrados e 10,5\% que não possuem registro em carteira. 24,1\% estão fora do mercado de trabalho (311 pessoas). São eles: aposentados e pensionistas 4,6\% donas de casa 8,4\%, estudantes $8,8 \%$, incapazes para o trabalho $2,2 \%$.

\section{Deficiências encontradas na população}

Do total da população no empreendimento, 18 pessoas, ou seja, 0,9\% é portadora de alguma deficiência física ou mental.

\section{Dados das famílias}

\section{Composição familiar}

Foram cadastradas 537 famílias na área. Considerando que são 1.995 pessoas, o número médio de pessoas por unidade familiar é 3,7 (pouco abaixo da média nacional que é de 3,8 pessoas por domicílio). A análise dos dados referentes à composição familiar mostra que $72,1 \%$ das famílias têm até quatro membros. As numerosas (com cinco membros ou mais) totalizam 27,9\% A maior incidência percentual está no intervalo que compreende as famílias com três e quatro membros $-46,2 \%$.

O número de chefes de família do sexo feminino é bastante significativo. Das 537 famílias pesquisadas, 308 são dirigidas por mulheres; ou seja, $57,4 \%$. As famílias cujos chefes de família são homens somam $42,6 \%$.

Nível de Escolaridade dos chefes de família.

O nível de escolaridade dos chefes de família é baixo. O percentual de analfabetos é de 8,6\% Um pouco mais de dois terços deles freqüentou ou freqüenta o ensino fundamental: $64,4 \%, 24,4 \%$ dos chefes cursaram o ensino médio e o percentual daqueles que alcançaram o nível superior é de 2,6\%, considerado bem pouco significativo.

\section{Situação Ocupacional dos Chefes de Família Economicamente Ativos.}

O quadro ocupacional dos chefes de família em idade economicamente ativa (449 pessoas) em sua maior parte é composto por empregados com registro (45,2\%) e sem registro (14,9\%), totalizando 60,1\% Cabe ressaltar que 13,8\% deles encontram-se desempregados, somando os que fazem bico - 17,1\%, chega-se ao significativo percentual de 30,9\% com dificuldades de inserção no mercado de trabalho.

\section{Faixas de renda familiar}


Analisando a renda familiar, observa-se que $17 \%$ das famílias vivem com até um salário mínim0 ${ }^{88}$. Vale ressaltar que 12 famílias $(2,3 \%)$ declararam viver sem renda alguma e que $26,3 \%$ declararam renda superior a 3 salários mínimos. 56,7\% possuem renda entre um a três salários mínimos. A renda média familiar é de 2,37 salários mínimos.

\section{Faixas de renda familiar per capita}

Em relação à renda per capita (definida como o quociente entre o número de membros da família e a renda familiar total), $76 \%$ situam-se na faixa até 1 salário mínimo mensal per capita sendo que, destas, 40,8\% encontram-se no estrato até 0,5 salário mínimo mensal $24,1 \%$ das famílias vivem com renda per capita acima de 1 salário mínimo. A média da renda per capita é de 0,79 salário mínimo.

\section{Situação Habitacional}

\section{Tempo de residência no domicílio}

75,9\% dos imóveis são ocupados pelos mesmos responsáveis há um período entre quatro a oito anos, demonstrando um processo de consolidação da demanda original. 6,3\% estão ocupando o domićlilo a menos de um ano. No que se refere à situação da moradia, observa-se que 98,5\% dos moradores declararam que em sua grande maioria são próprias (demanda original). Ressalte-se que essa resposta é a percepção dos moradores em considerarem que são donos de seus apartamentos, apesar de terem assinado o Termo de Permissão de Uso (TPU). No momento em que foi realizada a pesquisa no empreendimento, 1,3\% dos domicílios estavam cedidos/ocupados e um domicílio estava em regime de aluguel.

\section{Situação de moradia anterior}

O percentual de famílias que residiam em casa própria antes de se mudarem para as unidades habitacionais é de 59,6\% Os moradores de aluguel perfazem 20,9\%, aqueles que moravam em casas cedidas ou emprestadas perfazem 9,3\%, e em domicílios ocupados 10,1\% Todavia, esses dados não nos parecem fidedignos, se levarmos em consideração as mudanças pelas quais vem passando o empreendimento como um todo. Em primeiro lugar, a demanda original era toda constituída de moradores oriundos de áreas favelizadas, cabendo questionar, portanto, se as "casas próprias" de suas respostas eram os barracos das referidas áreas, que como é sabido não são regularizados, ou seja, não são próprios, mas são próprios do ponto de vista da percepção do morador. Ou os moradores egressos das casas próprias são aqueles segundos, ou terceiros moradores que não fazem parte da demanda original? Por outro lado,

880 salário mínimo vigente à época da pesquisa era de $\mathrm{R} \$ 300,00$. Importante salientar que 5 chefes de família não informaram a renda. 
também nas favelas existem dinâmicas de aluguel, empréstimo e cessão de moradias. Os dados como apresentados permitem concluir que a questão foi direcionada a todos os entrevistados sem a consideração desses aspectos.

\section{Termo de Permissão de Uso}

Dos 537 moradores entrevistados, 52,1\% declaram que o Termo de Permissão de Uso foi assinado em nome dos responsáveis pela unidade habitacional, 47,3\% declaram que o TPU não está assinado em seus nomes. Vale ressaltar que as famílias removidas em 1996 para as unidades habitacionais do Programa Operações Interligadas (120 famílias ao todo) nunca assinaram o Termo de Permissão de Uso, muito provavelmente em virtude das irregularidades apontadas pela CPI das Operações Interligadas (cf p 78).

\section{Pagamento da última taxa de retribuição}

65,2\% das famílias entrevistadas declararam que não fizeram o pagamento da Taxa de Retribuição do mês anterior ao da entrevista (350 pessoas). 34,8\% declararam que efetuaram o pagamento (187 pessoas). Das 350 pessoas inadimplentes, 22,6\% alegam o não pagamento do mês anterior por não possuírem renda suficiente para tal. Uma porcentagem muito relevante, de $56,6 \%$, declarou outros motivos para o não pagamento: aguarda regularização, desemprego, problemas financeiros, orientação para não pagar, não assinou o TPU. No entanto, 38,8\% das pessoas que declaram outros motivos, alegaram o não pagamento em virtude de não terem recebido o boleto com a cobrança. Desses dados, inferimos que a maioria das pessoas está inadimplente quanto à Taxa de Retribuição do Termo de Permissão de Uso. No entanto, o não pagamento não está relacionado à ausência de renda na maioria dos casos, mas à outras prioridades da família, como despesas de alimentação, telefone, energia elétrica, prestações de móveis, automóveis, taxas de condomínio e inclusive, à falha da Prefeitura Municipal no tocante ao envio dos boletos para o pagamento. Essas afirmações baseiam-se em dados dos relatórios citados, mas em virtude do detalhamento dos mesmos, não são possíveis de serem reproduzidos. Por outro lado, alguns moradores são cientes da condição de permissionários e propositalmente são inadimplentes quanto à obrigatoriedade de pagamento das taxas de retribuição. O raciocínio é: "se não sou proprietário, porque pagar?

O que nos remete a Seabra (1996) refletindo a "insurreição do uso", a partir de Henri Lefebvre: "Assim recusado, o uso continua como ausência, exclusão da propriedade, e como conflito, se concebendo como tal no âmbito das estratégias dos usadores. Nisso está o conflito, a insurgência do uso" (p.79) 
Vale lembrar que a insurreição do uso também se dá em outras esferas, pois, as políticas de provisão de habitação além de fazerem parte da agenda política, são também, e inclusive, "respostas" aos conflitos criados entre os movimentos sociais urbanos reivindicadores de habitação e o Estado.

Como bem assinala Seabra:

Lefebvre nos diz enfaticamente que a insurgência do uso no interior da problemática do espaço parece guardar elementos novos, pois esse conflito no e com o espaço vai gestando territorialidades novas, num espaço que revela, porque tornou empírico, o processo social, não obstante estar esquadrinhado por fluxos, redes e relações (op. cit, p.79).

Os conjuntos habitacionais são expressão dessas territorialidades novas.

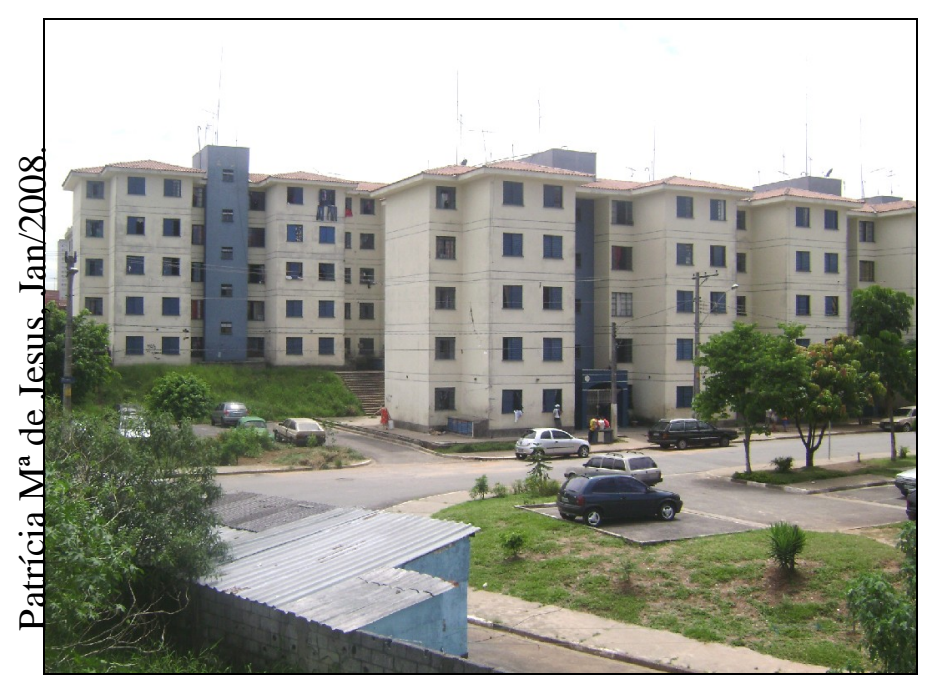

Foto 3: Panorâmica dos edifícios Cingapura. Observar as áreas vizinhas aos prédios, utilizadas como estacionamento (como previa o regulamento do Projeto). No canto inferior esquerdo da foto observar telhado de um estabelecimento comercial.

\subsection{Na aparente homogeneidade uma interlocução heterogênea.}

Os diferentes programas que constituíram a materialidade da área de nossa investigação demandaram de nós um olhar também diferenciado quanto à interpretação dos discursos dos moradores dos prédios de apartamento, pois, embora questionados de um modo geral sobre as mesmas questões que os moradores do Mutirão; suas trajetórias, perspectivas, percepções, e envolvimento com os respectivos programas de provisão de habitação, implicam 
necessariamente, em uma maneira significativamente diferente no que diz respeito à apropriação do espaço que habitam. Desse modo, embora externamente os prédios de apartamentos pareçam homogêneos, há internamente muitas dessemelhanças entre eles, que perpassam a concretude do edifício e resvala nas relações interpessoais. A fim de considerá-las, por acreditar que elas sustentam a complexidade da vida cotidiana, buscamos para nossa interlocução moradores residentes no Conjunto desde a sua implantação, aqueles que compraram um apartamento no Conjunto, e por isso são considerados segundos moradores, residentes na área ocupada pelo Centro Comunitário e também aqueles que construíram algum empreendimento comercial nas áreas comuns do Conjunto; e na falta de líderes ${ }^{89}$, pessoas que tenham exercido qualquer atividade semelhante no sentido de agregar sentimento de coletividade ao Conjunto.

Para moradores de edifícios (quer aqueles empreendidos pela iniciativa privada ou os promovidos pelo poder público) o pavimento em que se reside constitui significativa diferença na satisfação daquele que mora. Pois na maioria dos casos, morar no térreo é "quase sempre" um problema, ao contrário, residir no último pavimento do edifício é "quase sempre" mais agradável. A valorização de apartamentos em pavimentos térreos é normalmente menor que a valorização dos apartamentos de pavimentos superiores. Considerando essa diferença, conversamos em nossa área de estudo, com residentes do andar térreo, mas também de segundos, terceiros, quartos e últimos pavimentos. Abordamos moradores da Primeira, da Segunda e da Última rua como são denominadas pelos moradores desse conjunto habitacional. A "Última rua" como é conhecida a via que faz limites com o muro (e por esse motivo a última rua do empreendimento), é o local das "atividades ilícitas". Ouvir seus moradores foi fundamental, e não aqueles que praticam tais atividades, mas aqueles que sofrem (in)diretamente suas conseqüências.

Sobre o relato Michel de Certeau nos diz:

O relato é, em si, a teoria das práticas cotidianas de que trata. Porque constitui, ao mesmo tempo, uma discussão das práticas cotidianas e uma prática cotidiana em si. Ee próprio constitui a teoria daquilo que faz, daquilo que conta. Assim podemos analisar a narratividade como a teoria possível, o discurso teórico das práticas cotidianas. (Certeau, 1985).

Desse modo, apresentamos a seguir excertos dos relatos dos moradores e a análise dos mesmos, nos termos do autor supracitado constituído também uma prática cotidiana ${ }^{90}$.

89 Não há na área Associação de Moradores ou alguma entidade similar. Divergências entre os membros dissolveram as associações quer no Mutirão quer nos edifícios.

${ }^{90}$ Michel de Certeau é historiador e teólogo, tendo se dedicado a estudos de filosofia, lingüística e antropologia. Não é sua preocupação identificar o cotidiano como categoria explicativa da realidade concreta e tão pouco localizá-lo temporalmente no processo histórico, pois em sua obra a concepção de cotidiano aparece de forma abrangente historicamente. Sua atenção centra-se na tentativa da criação de uma "teoria das práticas cotidianas" construída a partir das "maneiras de fazer" do "homem ordinário". São as minúcias das práticas da vida cotidiana que o 
2.10 Moradores - Entre o inacreditável e a incredulidade.

2.10.1 O inacreditável.

Que na divina providência, os pobres depositam sobremaneira seus anseios e perspectivas, há muito se sabe, não importando de que modo ela se manifeste: no melhor emprego, em uma imperdível oportunidade, no concurso da loteria, na retribuição dos filhos, na complacência das entidades assistenciais, no cumprimento do poder público. O que contraria os conhecidos versos de Herbert Vianna "A arte de viver da fé, só não se sabe fé em que". № entanto, crença e descrença são pares dialéticos na vida cotidiana da população empobrecida da grande metrópole. Tanto é assim, que quando a providência da tão sonhada "casa própria" ocorre por meio do poder público, o sentimento inerente à população de menor renda é de descrença. $\mathrm{O}$ inacreditável é quase absolutamente mais concreto que as paredes de concreto dos edifícios.

Essa reflexão tem a função de introduzir as falas daqueles tão crentes e, por paradoxal que possa parecer, tão descrentes dos edifícios e de tudo o que eles representam. Suas habitações anteriores, ainda que precárias, construídas com materiais de toda sorte, em terrenos pouco apropriados do ponto de vista geotécnico, tão vulneráveis à chuva, ao vento, ao frio, ao calor, à violência, ao medo, ao barulho e cheiro alheios, são incrivelmente mais críveis.

E a descrença nos edifícios perpassa diversas causas: quanto à sua concretude, quanto à propriedade da casa própria materializada nos apartamentos, quanto à possibilidade de (re) produzir no conjunto habitacional alguns laços de solidariedade tão sólidos na favela, no círculo vicioso de viver e conviver novamente com hábitos e comportamentos que deveriam ter sido demolidos junto com a favela.

Foi assim: quando a gente foi morar lá então já tinha ouvido de quem já morava há muitos anos lá, que a Prefeitura queria tirar, queria tirar, mas ninguém acreditava aí depois de alguns anos, não sei a data exatamente, eu sei que mais ou menos em 96, 94 pra 95 começou um boato mais forte que ia sair, o IBGE esteve lá, marcando

interessam. As práticas cotidianas analisadas por Michel de Certeau são: ler, falar, caminhar, habitar, cozinhar. São as "artes de fazer" que deram origem ao estudo do autor intitulado A invenção do cotidiano: 1. Artes de fazer. Tradução: Ephraim F. Alves e Lourdes Endlich Orth. Petrópolis: Vozes, 1994. Especificamente as duas últimas práticas: habitar, cozinhar deram subsídios á um segundo momento de pesquisa de Michel de Certeau e dois outros pesquisadores (Luce Giard e Pierre Mayol). Suas contribuições deram origem a A invenção do cotidiano: 2. Morar, cozinhar. Tradução: Ephraim F. Alves e Lourdes Endlich Orth. Petrópolis: Vozes, 1996. Os dois tomos de A invenção do cotidiano referem-se ao bairro operário da Croix Rousse no subúrbio de Paris entre os anos de 1974 a 1978 e as análises de três gerações de uma mesma família no interior desse bairro. 
os barracos, os números e tal, mas ninguém acreditava porque devido muitas promessas, aí foi quando de repente do nada assim chegou(....)E a gente ficou morando no barraco da gente até construir aqui, mas muita gente morou nos alojamentos. Aí no dia de vim pra cá a gente viu derrubando o barraco foi muito dolorido. Doía porque aquilo ali a gente tinha de seguro, era nossa casa e aqui a gente não sabia se a gente podia se sentir bem, lá a gente já tava morando há vários anos, a gente tinha segurança, confiança, era tudo, e aqui a gente não tinha certeza se era nosso, sem entender lei, sem entender nada, então a gente ficava meio assim... ${ }^{91}$

O mesmo sentimento de desconfiança e descrença aparece em outros depoimentos:

Então a gente vivia num barraco, em cima da favela, em cima do rio. No São Domingos. Nessa daí eu fiquei grávida, uma mãe solteira, aí passou o pessoal fazendo cadastro. Eu achava que era mentira. (...) A gente ficou muito feliz né? Puxa vida! Sair da favela e ter minha casa. Porque até aí eu morava com a minha avó, mas eu tive direito a um apartamento porque eu tava grávida e ia ter o filho (...). Então quando saíram esses predinhos, que o pessoal falou assim "Olha vocês já vão assinar e pegar a chave", Nossa! Todo mundo ficou muito feliz. Ah! Mas cadê, onde que é? Foi quando eles mostraram, deram oportunidade. Trouxeram a gente de perua e vieram mostrar onde que eram os prédios. A gente veio conhecer. Nossa! Parecia ser um sonho. Um sonho que você estava realizando né? Falamos puta, conseguimos ter nossa casa? Hoje? Vai ter seu apartamento, você vai ter seu espaço. Eu não acreditava ${ }^{92}$.

Perder a segurança e a identidade da favela e transferi-la para o novo lugar de morar constituía-se como o grande desafio para os moradores contemplados pelo Projeto Cingapura:

O que era uma coisa muito prazerosa ali no lugar que nós morávamos e eu sentia muito isso, era como se a gente tivesse uma praia particular, então o quê que acontecia? Tinha um bar a 100 metros de casa onde nós assávamos carne e onde a Vitória adorava [referindo-se e apontando para a cachorra que dormia no canto da sala no momento da entrevista e que desde os tempos da favela acompanha a família ${ }^{93}$, participava de tudo isso, e onde a gente se sentia a gente mesmo, tinha uma identificação com aquele lugar, com aquelas pessoas e havia também o respeito. Natural né? Com as pessoas que estavam ali. Ainda que a gente tivesse as desavenças. Então isso a gente não teve aqui, aqui a coisa se espalhou, as pessoas se espalharam aqui ${ }^{4}$.

\subsubsection{Alienação projetada}

Chama-nos a atenção que os moradores contemplados pelo empreendimento do Projeto

Cingapura Parque Continental, assim como em todos os empreendimentos do mesmo Programa, não participaram do processo de sua execução, nem dos atos de sua rejeição, como

91 Grifos nossos sobre a fala de Soraia entrevistada em 06/06/2007.

92 Grifos nossos sobre a fala de Samara entrevistada em 30/06/2007.

93 Inserção nossa.

94 Grifos nossos sobre a fala de Roberta entrevistada em 02/07/2007. 
bem salientou Vanildo Silva (2003), em que relata as manifestações de diversos segmentos da sociedade civil contrários ao Projeto. Quando abordados sobre essa questão, há quase um uníssono sobre o desconhecimento do Programa, a falta de participação, a aparição "do nada" da equipe da Prefeitura nas favelas selecionadas para esse empreendimento.

Dentre as pessoas com as quais conversamos, aparece apenas em uma fala as manifestações de rejeição quanto ao Projeto, mas que, no entanto, foram insuficientes para fazer com que o mesmo fosse paralisado na favela em questão:

...Os que queriam mudar justamente queriam mudar pela benfeitoria, ah apartamento é legal, eu quero ir, e muitos não queriam porque moravam lá, trabalhavam lá, os filhos estudavam lá e não sabiam que aqui ia ser bom Era uma coisa insegura. Então não tinha nada assim fixo, não tinha nada seguro, então o pessoal ficou assim com medo. (...) E no final saiu todo mundo. Quem queria e quem não queria. No caso, fez o cadastro, você escolheu aonde? Aonde você escolheu, sua família escolheu, ou quem escolheu, vai. Como quem tava reivindicando que queria ou não queria, estava todo mundo num bolo só, quem queria vir ou não já tinha se cadastrado do mesmo jeito, já tinha escolhido, então ia para onde tinha escolhido, então quando saiu foi um pouco pra um lado, um pouco pro outro. Aí teve guerra, fecharam a rua em frente da 91, colocaram fogo no Centro de Associação da Prefeitura, o pessoal jogava aquele coktail molotov, sei lá o que era aquilo, acertou um dos peões que moravam no alojamento do lado, pegou fogo no alojamento. Isso tudo porque muita gente não queria vir. E também tinham os vândalos que se aproveitavam da situação. (Soraia)

Esse relato diz respeito à favela localizada nas adjacências do CEASA (Companhia de Entreposto e Armazéns Gerais de São Paulo) e próxima também ao 91ํㅡ Distrito Policial da cidade de São Paulo. Os moradores da referida área tiveram a "opção" de escolher entre o empreendimento do Parque Continental ou um empreendimento futuro a ser construído no distrito do Jaraguá. Ocorreu que as duas opções não eram aprazíveis à um número significativo de moradores que, como pudemos depreender do trecho acima, se rebelaram contra o Programa, pois, uma vez que já estavam cadastrados não era mais possível desistir do processo de mudança, até porque, a favela foi demolida exatamente no dia da transferência dos moradores.

Para Agnes Heller existe alienação quando ocorre um abismo entre o desenvolvimento humano-genérico e as possibilidades de desenvolvimento dos indivíduos humanos, entre a produção humano-genérica e a participação consciente do indivíduo nessa produção95. Para Henri Lefebvre, somente quando as pessoas não podem mais continuar a viver sua

95 In Sociología de la vida cotidiana, 1994. 
cotidianidade, então começa uma revolução. Só então. Enquanto puderem viver o cotidiano, as antigas relações se reconstituem ${ }^{96}$.

Para essa situação Lukács (apud Heller, 1994) cunhou a expressão "saída da cotidianidade", ou seja, quando uma determinada atividade, menos mecânica e manipulativa que as comumentes observadas no cotidiano ocorrem, um empreendimento onde o sujeito empreenda toda sua força, num processo que envolva a consciência de sua qualidade humanogenérica, nessas circunstâncias, acontecerá a suspensão temporária da heterogeneidade. Aí o indivíduo emprega sua inteira individualidade e quando retorna para o cotidiano, para a heterogeneidade cotidiana, estará mais bem preparado para continuar agindo porque detém, nesse patamar, uma nova perspicácia. Vejamos que no caso descrito acima, a alienação dos moradores em relação ao projeto Cingapura intimidou a embrionária revolta dos mesmos no tocante ao Programa.

2.10.3 É diferente, mas é igual!

Uma vez remanejados para o Conjunto Habitacional pronto, as diferenças do apartamento no Conjunto e do barraco na favela são constantes e enfatizadas em seus relatos:

Mas tenho fé em Deus, que Deus é pai, um dia eu vou sair daqui. O mesmo que me deu esse teto, ele me tirou da favela, e aqui com certeza é melhor $99 \%$ do que a favela, ele vai me dar também, se Deus quiser, outro melhor de que esse ${ }^{97}$.

Rindo ao contar, Soraia lembra das diferenças:

Até hoje nós comentamos lá em casa, que aqui tinha muita tomada, coisa que lá no barraco a gente tinha uma e olhe lá né? Um bico de luz e umbico de tomada só. Aí falei pra minha mãe, foi quando a gente veio, aí foi saindo um pouco do pessoal, a nossa turma foi a última a sair quando nós viemos pra cá foi legal. Vixe, a hora que eu vi aqui assim, eu pensei: meu Deus! Era diferente, muita diferença: um monte de tomada em cada cômodo, cozinha com pia, o banheiro com chuveiro, era só você instalar, o quarto com janela, dois quartos. Nossa. Foi tudo!

Dona Lourdes enfatiza a insalubridade da favela:

Na favela do CEASA eu morava num barraco né? Então pra mim aqui foi uma ótima moradia né? Porque sair do barraco e vir pra um apartamento, nossa! Mi maravilhas. Não tenho o que falar daqui não (...). É como eu te falei, a gente morava num barraco, numa área de risco de enchente, rato pra lá e pra cá, quando chovia molhava mais dentro do que fora né? Então eu posso dizer que eu adorei, eu gostei,

96 In A vida cotidiana no mundo moderno, 1991. Ver apreciação sobre Agnes Heller e Henri Lefebvre no capítulo III desse trabalho.

${ }_{97}$ Adelina, em entrevista concedida em 29/06/07. 
porque é como eu te falei: sair de um pedaço de madeira de um barraco pra vir pra um apartamento desse aqui, nossa senhora! Se não gostar também é muito ingrata né?98

Roberta e a mãe que sempre moraram de aluguel, foram morar "provisoriamente" na favela, pouco após à mudança a área foi escolhida para a intervenção do Projeto Cingapura. Por esse motivo, a favela as impressionava:

Eu também observava, a casa que eu morava, eu ficava pensando como é que aquilo não caía. Eu refletia "como esse barraco de madeira não cai"? Já que ele era tão frágil e não caía. Então de tudo o que acontecia e que era novidade pra mim, jogar o lixo no rio e aquele rio quando chovia subia e a quantidade de ratos que aquilo acumulava, essa parte pra mim era a parte mais deprimente de tudo o que aconteceu. E é lógico que desse ponto de vista os apartamentos são muito melhores. Por isso quando a gente mudou além de medo a gente sentiu também alívio.

Todavia, se há no Conjunto diferenças estruturais quando comparado à favela, há também semelhanças na maioria das vezes mal vindas e mal vistas pelos moradores. Vejamos 0 que dizem sobre tal questão:

Favela é sempre favela. Nunca vai mudar. Não é porque aqui é um prédio que deixou de ser favela. Não deixou, porque infelizmente as pessoas fazem a moradia de favela. Entendeu? Aí foi por essa questão que eu não fiquei lá. Falei: "Eu vou lá pro Continental porque lá não é favela. Vai valorizar o apartamento também". Mesmo que fosse só de um dormitório. Foi por isso que eu vim pra cá. (Samara)

Quando eu vim pra cá eu esperava que fosse diferente, que fosse melhor, que não fosse igual à favela. E aqui é igual. Porque eu sou muito do respeito, eu respeito todo mundo, mas eu acho que também tem que me respeitar sabe? Então eu vou muito pelo respeito, pela educação, e são coisas que aqui não tem. (Pâmela)

Uma de nossas interlocutoras, avaliando o Projeto Cingapura toca no mesmo assunto:

O Projeto não é ruim, o Projeto é ótimo. O problema do Projeto, é que quem faz o lugar são as pessoas. E aqui as pessoas em vez de valorizarem o Projeto, valorizarem o lugar, não valorizam. Entendeu? As pessoas moram na favela, podiam deixar a favela lá e não trazer a favela junto. A pessoa trouxe a favela junto com o Mutirão e com o Cingapura.

E nos dá um exemplo da principal semelhança na opinião de muitos moradores entre o conjunto de prédios de apartamentos e o espaço da favela:

98 Em entrevista concedida em 29/07/07. 
Aqui, esse bloco é limpinho, mas se você vai no bloco onde minha tia mora que é no 8, ninguém agüenta. É tudo zuado, as pessoas não cuidam, é igual na favela, não entendem que ali é pra eles mesmos. Eu quando vou lá eu não agüento subir naquele lugar. Onde ela mora (o andar) é bem limpinho, vai nos outros... Você já chegou a entrar naquele bloco? Então entra pra você ver. (Amanda)

\subsubsection{Favela vertical, e de alvenaria!}

São muitos aqueles que analogicamente referem-se ao empreendimento como uma favela vertical, ou uma favela de alvenaria e expondo seus motivos, são enfáticos no que diz respeito à apropriação do espaço público por alguns poucos moradores e, da maneira específica como esses espaços são apropriados. Tratam-se das inúmeras "barracas" que alguns moradores edificam e lhes dão como uso principal um empreendimento comercial ou de senviços: são bares, açougue, vidraçaria, quitanda, comércio de jogos eletrônicos, cabeleireiro, bicicletaria, mecânico, igreja, etc. O advento desses empreendimentos vem aumentando nos últimos anos, sobretudo em virtude da omissão do poder público municipal no tocante a essa questão. Se por um lado, a equipe da Prefeitura falhou em não prever na área do Conjunto espaço para estabelecimentos comerciais e de senviços (muitas vezes essenciais para o sustento das famílias oriundas de áreas favelizadas), por outro, na impossibilidade de contêlos, omitiu-se em relação ao fato, o que acarretou num aumento significativo de empreendimentos dessa natureza. As opiniões dividem-se entre os empreendedores, usuários e aqueles que vêem a idéia como absurda, por desvalorizar e enfear a área do Conjunto.

Vale acrescentar que, muito recentemente, houve na área boatos de moradores que estariam denunciando a existência das "barracas" para a Prefeitura. Intimidados com a possibilidade de terem seus negócios ameaçados, os donos mantiveram por dois dias seus estabelecimentos fechados ao saber da visita de técnicos de Prefeitura. Questionados sobre tal questão, não sabem da veracidade da informação, mas preferem não arriscar. Uma de nossas visitas ao empreendimento, para continuar o procedimento de entrevista, coincidiu com um desses dias em que houve o fechamento do comércio. Dias depois, voltamos à área dispostos a entrevistar os "empreendedores". Certamente encontramos resistências. A seguir, os depoimentos dos únicos dispostos a falar, mas que acreditamos que sintetizam bem as opiniões possíveis acerca desse pormenor:

Assim se manifestam os proprietários: 
Eu não sei qual o problema. Porque não posso ter aqui um comércio? É um trabalho como outro qualquer, não pedi nada a ninguém pra construir, gastei meu próprio dinheiro, e a área estava aí ociosa, só juntando lixo e bagunça. (Abelardo)

Então é complicado, porque eu estou sem emprego há muito tempo, procurando, procurando e nada. E não sou só eu, tantos brasileiros aí. O que eu faço aqui é pra ajudar os próprios moradores daqui e também não estou de papo pra o ar, estou trabalhando. A Prefeitura disse que não podia, mas nunca veio aqui reclamar comigo não. (Jeremias)

Ué? Se não tivesse quem comprasse eu não vendia. Isso aí ninguém enxerga. É cada uma! E tem outra: na favela eu sempre tive bar, sempre, sempre. E onde aqui no Jaguaré que a pessoa vai comprar uma caixa de fósforo só quando está precisando? Vai arrumar um botijão de gás rápido se o gás acabou? Vai comprar uma pedra de sabão, ou um cigarro solto. E comprar fiado? No Extra? O que acontece é que tem gente querendo ser demais sem poder. Está no lugar errado. (Clotilde)

Vejamos agora, os que são contrários aos estabelecimentos:

Eu até hoje luto por isso, eu luto pra tirar essas bagunças daí logo. Porque eu sou contra. Esse estacionamento, com barzinho na porta. Que isso? Tirou toda a visão do meu apartamento, quebrou o jardim pra fazer. E, além disso, é feio, é visivelmente muito feio, feito de madeira, de zinco, é igual à favela. (Samara)

Porque você acha que todos os moradores aqui gostam de ter suas garagens virada um forró, um bar que tem forró final de semana? Não é todo mundo que gosta né? Tem uns ou outros que gostam, mas aí você também não pode criticar esse que fez isso, porque quando ele morava na favela ele tinha o bar dele que é a renda dele. Então não tem como. Porque a Prefeitura não veio falar: "Essa é a sua renda, então a gente vai ter que providenciar um estabelecimento ou ver algum lugar, porque esse é o seu ganha pão". Então não dá pra julgar as pessoas, fica difícil. Mas o fato é que nem todo mundo quer que a sua garagem seja o point do forró, ou o lugar que vende o pão, ou o lugar que vende a carne, porque não foi isso que nós assinamos, lá no contrato esse é o lugar da garagem. (Pâmela)

Pâmela se pronuncia contra os estabelecimentos, mas consegue relativizar o problema:

Talvez não tivesse a necessidade deles existirem já que a gente mora em uma região que tem muito comércio, a gente tem padaria, mercado, em tudo que é lugar. Mas enfim.. é o ganha pão dessas pessoas, que elas sempre viveram disso. Não tem outra profissão. É do que elas sempre viveram, você vai tirar isso delas agora? Não tem como tirar. 
Entre a compreensão de uns, a incompreensão de outros, a condescendência de uma parca minoria, e a omissão da Prefeitura, os estabelecimentos proliferam em qualquer área não edificada: entre os prédios ou atrás deles, nas áreas "reservadas" aos estacionamentos, na calçada do muro que margeia o Conjunto.

Interessante observar que os estabelecimentos comerciais ou de senviços representam mais que isso. Reproduzem o conteúdo de um modo muito especifico de relacionamento das favelas, transposto, reteritorializado no Conjunto Habitacional. Essenciais nesses espaços, por permitirem o pagamento "fiado" ${ }^{99}$ para uma população empobrecida, por admitirem a compra aos "pedacinhos": uma barra de sabão, um único cigarro, ou um único pão, dois ovos. E proporcionar a obtenção do produto sem que o adquirente tenha que passar por todas as normas de condutas da sociedade, pois há quem desça do prédio para comprar o pão de pijamas, e cabelos desgrenhados. Por permitirem a presença do cliente cotidianamente sem que necessariamente haja a troca fundamental dos estabelecimentos (produto/dinheiro) (serviço/dinheiro), pois, por vezes, é o papo que interessa. Os forrós aos finais de semana, ainda que em "áreas irregulares", são imprescindíveis para recarregar a energia perdida nos tempos impostos (para usar a expressão de Henri Lefebvre) de transportes coletivos, distâncias, tráfego intenso, burocracia. Também no caso do forró (nem senviço, nem comércio), mas lazer imediato, a idéia de uma proprietária é coerente: só há os empreendimentos, porque há quem os freqüente.

99 "Fiado" é sinônimo de pagamento à prazo. 


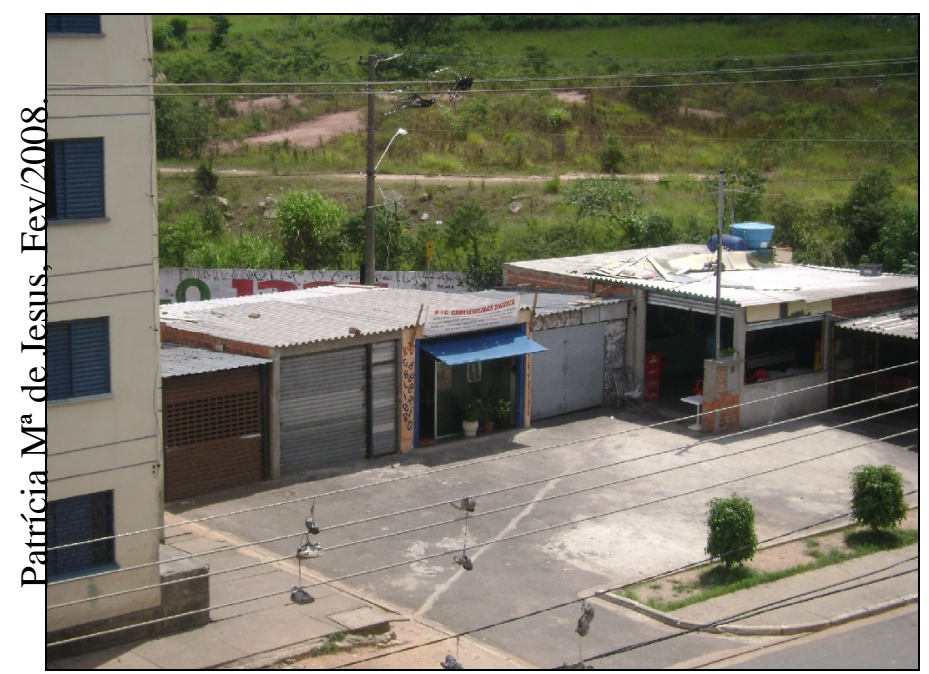

Foto 4: Exemplo de espaço comum apropriado de forma individual: área de estacionamento onde podemos notar a existência de garagens fechadas, salão de cabeleireiro, bares e loja de produtos de limpeza. Em um dos bares acontece o forró. Em segundo plano observar terreno baldio vizinho ao Conjunto.

Atentamos ao leitor, não é da favela que tratamos, mas daquilo que dela restou, que transbordou as paredes de madeira e zinco, e seus interstícios. E resiste, para o bem ou para o mal às aspirações daqueles que querem exorcizar o "espírito mal" dessa forma urbana.

Muitos viram na mudança do barraco para o apartamento, e da favela para o Projeto Cingapura Parque Continental, desprovido dessas áreas em seu entorno imediato, uma clara oportunidade de "mudar de vida":

\begin{abstract}
A minha relação agora é boa, eu vivo bem, por causa que muita gente saiu da favela para ter uma vida melhor e não entende que aqui a vida mudou. Muita gente não entende que a vida mudou então, vende, dá por troco de nada e depois vai ver não deu certo, vendeu e tá sem nada. (...) Aqui é um bairro100 que só tem a mostrar pra você que você pode crescer, pode mudar desde que você queira, então é legal. Então não é vantagem vender. Algumas pessoas vendem pra voltar pra terra, ou pra voltar pra favela. Mas que adianta você voltar com dinheiro, mas você voltar com a mente vazia, com a mente sem nada? Você tem que voltar com uma produtividade. (Soraia)
\end{abstract}

Em suas opiniões para mudar de vida, a localização do empreendimento é primordial, é o que pudemos verificar nos dois trechos a seguir:

100 Referindo-se ao empreendimento especificamente e não ao bairro do Jaguaré, onde ele está situado. 
Muitas coisas mudaram ao longo desses oito anos que eu estou aqui. Com certeza, porque a localização, os lugares que eu vou, é muito bom ter um vizinho de classe média ${ }^{101}$, é muito bom ter relações com pessoas que tenham condições socioeconômicas melhores, isso inspira (...) Eu acredito que meu cotidiano tenha mudado em função disso, de estar nesse entorno que realmente é muito mais estimulante que o entorno da favela lá do Rio Pequeno. (Roberta)

Mas a gente olhou pra região, em torno da região, como eu citei, eu quis morar aqui, eu trouxe minha mãe porque pra mim era conveniente, meus dois empregos são aqui em Osasco, próximos, muito próximos. Faço faculdade aqui também, eu vi que tinham duas universidades, que eu tinha opção de escolha agora para universidade, o bairro tem um centro comercial, que é muito conveniente pra qualquer um que more na região ${ }^{102}$. (Pâmela)

Para alguns oriundos da favela, mudar a estrutura da moradia (barraco para apartamento) não seria suficiente, era preciso mudar radicalmente "eu vou lá pro Continental porque lá não é favela", como bem salientou uma moradora.

Seria ingênuo acreditarmos que por tratar-se de uma população relativamente homogênea do ponto de vista socioeconômico, os moradores do Projeto Cingapura Parque Continental são aspirantes aos mesmos projetos, às mesmas realizações e compartilham dos mesmos valores de educação, salubridade, sociabilidade, enfim Significa dizer, que os conflitos cotidianos do Conjunto tendem sempre a aumentar. Não que eles não existissem na experiência habitacional anterior, quer tenha sido ela favela, aluguel ou similares. Entretanto, tanto na favela, como nas habitações alugadas, os conflitos esboroavam ou não encontravam eco. E é razoável supor que isso ocorria porque a apropriação não perpassava o espaço privado da casa. Como proprietário da moradia, é um disparate "brigar" a despeito da possibilidade de sofrer ação de despejo. Na favela, o "poder paralelo" do crime e do tráfico de drogas rege normas e códigos de conduta que emudecem moradores, mesmo os mais indignados, até porque além desse poder, outro não há nos espaços segregados e estigmatizados da favela.

Contrariamente a esse quadro, no Conjunto Habitacional Parque Continental há muitos poderes disputando o mesmo espaço: o "poder paralelo" do crime e do tráfico também (re) desenhado, (re) produzido na homogeneidade das ruas e prédios; o poder do Estado no que

101 Referindo-se ao loteamento Parque Continental.

102 Segunda moradora que anos atrás passando em frente ao empreendimento rumo ao caixa eletrônico do Shopping Center Continental, vislumbrou a possibilidade de moradia. 
respeita à produção (no sentido estrito do termo) desse espaço, e também, no que respeita à permissão do uso dos apartamentos pelos moradores; o "poder" daqueles que lutam ainda que de maneira frágil pela limpeza, asseio dos espaços e regras de convivência que beneficiam "todo mundo", como a tão polêmica lei do silêncio após as 22:00 horas, e melhorias físicas: portões que isolem os prédios entre si, interfones e chaves internas nos blocos, pintura interna, etc. E o "poder" daqueles que não querem ter poder, para quem pouco importam interfones, chaves, lixeiras em cada andar, contas em dia. Sobre esses últimos, arriscamo-nos a pensar serem seres "invisíveis", pois, suas marcas estão por toda parte: portões e interfones danificados, lixeiras quebradas, lixos espalhados, recados destruídos. No entanto, não sabemos de seus pronunciamentos, de suas opiniões. Quem são? Onde estão? Porque agem assim? E uma dúvida acomete-nos: seriam exatamente aqueles que reclamam, como o animal que senta em cima do próprio rabo para não vêlo? Ou ao contrário: são aqueles que se negam a falar, nos seus termos "por não terem com o que contribuir"103. Uma terceira hipótese: nem estes, nem aqueles. Sendo assim, são efetivamente seres "invisíveis"! E para que o último ato dessa investigação seja possível nesse "território do cotidiano", melhor renunciar nossa "curiosidade", ou saná-la por outras fendas, como faremos no terceiro e último capítulo desse trabalho.

\subsubsection{Incredulidades}

Entre o que é, e o que deveria ter sido, a incredulidade comparece com toda potência e tem várias orientações: a falta de respeito, as coações, a complexidade da situação fundiária, o desvio do projeto original.

Sobre ter uma casa boa num lugar ruim:

Aqui dentro de minha casa eu adoro. Se eu pudesse pegar essa casa aqui e por lá, por na cabeça e por lá em outro qualquer lugar que eu conseguisse era bom demais. Pra mim só não é melhor porque não é maior, pra ser perfeito, mas mesmo assim está muito bom Agora o lugar, é o ambiente assim, as pessoas não respeitam a gente e isso faz a gente ficar com desgosto. (Adelina)

Porque assim, como que um morador vai ter peito pra enfrentar todo mundo que está querendo fazer uma bagunça aonde mora? Eu vou ser sincera: eu estou já desgostosa daqui justamente por causa disso. (...) Se um dia essa gravação puder passar pra Prefeitura, pode passar, porque eu acho que eles têm que tomar uma providência. Entendeu? Porque os moradores sozinhos não conseguem Muitos estão indo embora, muitos estão desanimando sabia? E vai ser daí pra pior, porque vai sair os bons e ficar os ruins aí vai chegar uma hora que isso daqui vai cair tudo. (Samara)

103 Foi o que ouvimos mais de uma vez quando abordamos os moradores, a fim de entrevistá-los. 
Esse último trecho, diz respeito especificamente à dificuldade de morar no andar térreo em virtude do barulho constante das crianças, que por não terem espaço apropriado para brincar, apropriam-se desse andar. São elas mesmas que também pedemágua, inúmeras vezes aos moradores desse pavimento, economizando energia e tempo que gastariam para subir as escadas até o quarto ou quinto andares. A sujeira do térreo não vem do céu, mas vem do alto, das janelas dos outros apartamentos em andares superiores: cascas de banana, fraldas descartáveis, bitucas de cigarro, preservativos usados, embalagens de chicletes, os próprios chicletes, chocolate, cigarro, salgadinho, panfletos de supermercados da vizinhança, papéis de toda sorte. Quando vem de baixo, a sujeira vem da proximidade com as lixeiras, dispostas defronte aos prédios e do mau acondicionamento do lixo ${ }^{104}$. Responsáveis pela sujeira do térreo, também são as pessoas que por ali circulam, por ali consomem. Entretanto, o lixo não tem mais dono depois de esvaziadas as garrafas e pacotes, depois de saboreadas as frutas, os picolés, as pizzas.

Os jovens e os adolescentes, também eles desprovidos de local apropriado para conversar, ouvir música, namorar, ou dividir uma pizza, escolhem o pavimento ao rés-do-chão. Não raro, pedem aos moradores desse andar um copo que faltou para alguém que chegou exatamente na hora de abrir a Coca-Cola, um isqueiro para acender "os cigarros", uma caneta para usar rapidinho, e a bendita chave para abrir o portão, pois o interfone quebrou, o pai dormiu, e a mãe não ouve os gritos, privilégio dos moradores do andar térreo! Todos os aspectos descritos acima, também comparecem em edifícios empreendidos para demandas de média e alta renda, porém nesses casos se há o descumprimento de regras no que diz respeito a descarte de embalagens e lixos, silêncio e uso de espaços comuns, há também multas e outras formas de inibir e ou coibir algumas práticas. A intervenção de zeladores, síndicos, porteiros, administradores e outros moradores faz com que as regras sejam em grande medida respeitadas. Es o que não há nos conjuntos habitacionais concebidos para a população de menor renda.

Referindo-se ao processo de regularização fundiária em processo e à falta de orientação das pessoas por parte do poder público municipal:

Eu acredito até que o fato das pessoas estarem saindo daqui, evadindo daqui é porque elas ficaram tão descontentes com todo esse processo que isso gerou um

104 Uma das reivindicações dos moradores identificada pela Prefeitura quando da realização da pesquisa foi a troca das lixeiras atuais por lixeiras de alvenaria. Isso porque as atuais lixeiras instaladas no Conjunto são vazadas, portanto muitos sacos de lixo caem no chão, facilitando o acesso de animais, que espalham o lixo. (Diagnóstico Integrado, 2005, p.68). 
desvalor mesmo, uma insatisfação. Isso é um dos fatores, porque eu percebi inclusive que depois de todo esse processo a gente tem muito mais pessoas indo embora. (Roberta)

Sobre a frustração quanto à expectativa de possíveis melhoras para o empreendimento, uma segunda moradora se pronuncia:

Porque você tem uma primeira visão só que você imagina sempre que as coisas vão mudar, vão melhorar né? Só que as coisas não andaram muito como a gente achou que iria andar. (Risos). Mas enfim... aqui pelo menos em casa a gente está satisfeita (...) Muita gente foi embora, as pessoas ganham o apartamento pra pagar um valor assim irrisório e de repente essas pessoas deixam, não querem mais morar no apartamento né? Ter uma habitação com saneamento básico tudo bonitinho pra voltar pra favela, preferir a favela. Será que eles preferiam a favela mesmo?

Cientes de que um programa de habitação além de agenda de políticos é também resposta de demandas urbanas, os moradores (nesse caso específico) mesmo que não tenham reivindicado diretamente pela moradia como salientam em seus relatos, o fizeram indiretamente, mesmo que "somente" fazendo parte das estatísticas que compõem o déficit habitacional da cidade de São Paulo. Incrédulos e pessimistas quanto ao futuro, têm inúmeras idéias para melhorar o espaço que habitam, para que a apropriação ocorra num outro nível de vínculo com esse espaço, uma vez que não puderam opinar na execução do Projeto Cingapura: uma lan house para os adolescentes, banquinhos em frente aos prédios para as pessoas sentarem, assim como, em um condomínio de rico (como faz questão de comparar uma moradora), coleta seletiva de resíduos sólidos, dado o significativo número de moradores, uma creche no Conjunto, um posto de saúde mais próximo, pois a Unidade Básica de Saúde não supre a demanda do bairro ${ }^{105}$, o fechamento de cada um dos prédios com portões e interfones ${ }^{106}$, uma Associação de Moradores. Os "donos" das idéias, ao defendêlas emendam um sonoro "mas uma andorinha só não faz verão". Vejamos que temos muitas andorinhas e um mesmo "verão", todavia os projetos não caminham, ainda que como digam os próprios moradores, temos no espaço constituído de Mutirão e Cingapura "um caldeirão de gente interessante", "mão-de-obra pra tudo". Estariam todas essas andorinhas voando por diferentes céus?

105 Até o fechamento desse texto, uma moradora organizava um abaixo assinado para solicitar um Posto de Saúde nas proximidades do Conjunto. Precisamente em um imóvel da municipalidade atualmente inutilizado no Parque Continental. Ao mesmo tempo os moradores do Parque Continental organizam um abaixo assinado contra o Posto de Saúde alegando ser o bairro estritamente residencial, não havendo necessidade de um estabelecimento dessa natureza.

${ }^{106}$ Da totalidade dos edifícios alguns já contam com portões e interfones. Equipamentos desejados por moradores de outros edifícios que não conseguem o mesmo nível de organização necessário para sua implementação. 
No "céu cotidiano" e imediato de nosso Conjunto Habitacional, inúmeras outras práticas acontecem, analisá-las mais de perto, no centro da ação, e no ato de sua realização é nossa tarefa no próximo e último capítulo de nossa investigação. 
Emtorno deles a liberdade do domingo punha alegrias naquela tarde Mulheres amamentavam o filhinho ali mesmo, ao ar livre, mostrando a uberdade das tetas cheias Havia muito riso, muito pardar de papagaios; pequenos travessavam tão depressa rindo como chorandb; (...) a aviamse cantigas e pragas entre gargalhadas.

Aluísio Azevedo. 
3.1 Para analisar a vida cotidiana. 106

3.2 Cotidiano X Modernidade: a relação entre ambos. 107

3.3 Henri Lefebvre e a vida cotidiana no mundo moderno

3.4 Habitar X habitat: vivendo no Conjunto.

3.50 movimento da rua.

3.6 A casa e seu movimento

3.7 Espaço cotidiano - o lazer praticado no Conjunto.

3.8 Tempo cotidiano - não linear e agora

Para analisar as práticas cotidianas do Conjunto Habitacional Parque Continental,fizemos uso da descrição analítica dos processos e dinâmicas observados. Nesse sentido, temos a intenção de contemplar tanto quanto isso é possível, as diferentes dimensões da vida cotidiana: trabalho, vida privada e lazer, sempre voltando nossa atenção para a apropriação dos moradores com o espaço constituído pelo conjunto habitacional. A tentativa é analisá-las em sua totalidade e não uma em detrimento da outra, por acreditarmos que suas inter-relações e suas coexistências é que compõem a complexa trama da vida cotidiana.

A vida cotidiana anunciada nos capítulos anteriores desse trabalho, nesse momento transborda, resvala, insiste, persiste. Lá estão as ocupações formais, as ocupações informais itinerantes, e as ocupações informais no espaço do Conjunto. As comemorações: aniversários, casamentos, batizados, formaturas. O lazer programado, o consumo. Os encontros: festas, forrós, cultos, churrasco, futebol. Os desencontros: mortes naturais ou induzidas, adultérios, violências, crimes. Na casa, na rua, entre a casa e a rua os mexericos, cochichos, fofocas, futricas.

Obsenvar a vida cotidiana com toda sua riqueza e toda sua pobreza exige encurtar as distâncias, não só práticas, mas também teóricas. Significa dizer que, assim como são necessárias observação, participação, e descrição da realidade em questão, não menos importantes são as contribuições teóricas que nos subsidiam.

São dois os níveis de análise: um primeiro que diz respeito ao cotidiano como modo de vida espećfíco da contemporaneidade capitalista e um segundo, que se refere à análise da vida cotidiana regida por esse modo de vida. 
3.2 Cotidiano X Modernidade: a relação entre ambos.

Para introduzir nossa incursão na vida cotidiana, apresentamos a relação entre o cotidiano e a período moderno da história. Por pelo menos dois motivos: a concepção das políticas de habitação que analisamos (padrão arquitetônico, a homogeneidade das unidades habitacionais proposta pelos projetos, as técnicas empregadas) encontra subsídios nos ideais da modernidade ${ }^{107}$, por outro lado, diversos autores relacionam a modernidade no bojo de sua crise e o cotidiano. Este último aparecendo como surgido daquela, e ainda que não tenhamos elegido tal conceito para o curso dessa pesquisa, sua relevância é inegável, pela persistência em que apareceu no processo de revisão bibliográfica. Não podíamos ficar isentos a ele.

Sobre tal perspectiva Lefebvre nos diz:

São as duas faces do espírito do tempo. Ao cotidiano, conjunto do insignificante (concentrado pelo conceito), responde e corresponde o moderno, conjunto dos signos pelos quais essa sociedade se significa, se justifica, e que faz parte da sua ideologia.(...) Cotidiano e modernidade: duas "realidades" solidárias, tão poderosas quanto pouco conscientes antes de terem sido transpostas para a linguagem e para o conceito: a cotidianidade e a modernidade. (...) São simultâneas e relacionadas. $\left(1991\right.$, p.30) ${ }^{108}$.

A crise da modernidade em Lefebvre reflete o cotidiano, e também a crise dele, e como conseqüência sua incapacidade de criação. Lembrando que a capacidade criadora era uma das propostas da modemidade, uma vez que para o autor, é no cotidiano que as necessidades são satisfeitas.

Ainda relacionando cotidiano e modernidade:

O cotidiano é o humilde e o sólido, aquilo que vai por si mesmo, aquilo cujas partes e fragmentos se encadeiam num emprego do tempo. E isso sem que o interessado tenha de examinar articulações dessas partes. É, portanto aquilo que não tem data. É o insignificante (aparentemente); ele ocupa e preocupa e, no entanto, não tem necessidade de ser dito, é uma ética subjacente ao emprego do tempo, uma estética da decoração desse tempo empregado. É o que se une à modernidade. Por esta palavra é preciso entender o que traz o signo do novo e da novidade: o brilho, o paradoxal marcado pela tecnicidade ou pelo mundano. É $O$ audacioso

\footnotetext{
107 No âmbito desse trabalho entendemos modernidade como o período que se relaciona com o surgimento da sociedade urbano-industrial, portanto, após a Revolução Industrial irrompida no século XVIII.

${ }_{108}$ Ressalte-se que o estudo do autor tomado como referência principal no presente trabalho é A vida cotidiana no mundo moderno, escrito na década de 1970, e traz já no título sua maior preocupação: a vida cotidiana na modernidade, uma vez que seus estudos precursores a respeito da vida cotidiana datam de 1946 e anos subseqüentes com os três volumes da obra A crítica da vida cotidiana.
} 
(aparentemente), o efêmero, a aventura que se proclama e que se faz aclamar. É a arte e o estetismo, mal discerníveis nos espetáculos que o mundo dito moderno apresenta e no espetáculo de si que ele apresenta a si mesmo. Ora, cada um deles, o cotidiano e o moderno, marca e mascara, legitima e compensa o outro. São as duas faces de uma realidade tão espantosa quanto a ficção: a sociedade em que vivemos. Uma não é de maneira alguma o significante, e o outro o significado. Essas duas faces se significam reciprocamente ${ }^{109}$. (idem, p.31)

Para Petersen a emergência da temática da vida cotidiana está relacionada com a crise da modernidade, por pelo menos dois de seus efeitos: 1)De um lado, a crítica à epistemologia racionalista, às grandes narrativas legitimadoras, à hegemonia do discurso científico e o reconhecimento do estatuto gnosiológico de outras formas de conhecimento, como o senso comum, forma do pensamento cotidiano por excelência; 2) Por outro lado, a recusa às grandes sínteses, aos macrobjetos, às explicações de caráter estrutural, voltando-se ao fragmentário, fortuito, indeterminado, irracional e micrológico, que aparentemente são conteúdos da vida cotidiana. (p.49).

Também em relação à crise da modernidade, Barcellos (1995) remete ao imaginário dos anos 1980 marcado pela constatação da crise da Teoria do Conhecimento. Crise para ele gerada no interior de uma visão de mundo que dava unidade e sentido à realidade: o marxismo. Para o autor, a principal visão de mundo herdada da modemidade, inspirada do pensamento social contemporâneo, no século XX mostrou suas fragilidades e, as noções de território e cotidiano podem ser palavras-chave no esforço da renovação frente à crise do saber atual (p.40).

Martins (1998) preocupado que está com o interesse sociológico pela vida cotidiana, encontra a sociologia como uma expressão da modernidade. Para ele, estamos diante de um fascinante processo de reinvenção da sociedade, mas também de reinvenção da sociologia. (p.56). Para esse autor:

As grandes certezas terminaram E com elas entraram em crise as grandes estruturas da riqueza e do poder (e também os grandes esquemas teóricos). Daí decorrem os desafios deste nosso tempo. Os desafios da vida e os desafios da ciência, da renovação do pensamento sociológico. Se a vida de todo o dia se tornou o refúgio dos céticos, tornou-se igualmente o ponto de referência das novas esperanças da sociedade. (op. cit, 57).

Ao discutir cotidiano e modo de vida, para Seabra (2004) a vida cotidiana como conceito refere-se aos conteúdos da vida na modernidade, os quais seguem sendo transformados pelas

109 Grifo nosso. 
tecnologias do cotidiano e por elas modulados, caracterizando uma maneira de viver ou um modo de vida regido pela lógica da mercadoria (p.190).

Segue o mesmo raciocínio Carlos (2004), para quem:

A produção do cotidiano, hoje no mundo moderno, vincula-se a ampla difusão do consumo que criou o reino da mercadoria, na conseqüente penetração das relações capitalistas na esfera doméstica associada à necessidade de reprodução do capital através da reprodução das relações sociais que produz um modo de vida, um modo de consumo, um tipo de consumidor, valores e necessidades. (p. 63).

Souza (1997) ao analisar a proposta política de produção de habitação popular da Secretaria Municipal da Habitação de São Paulo no período de 1989 a 1992, o faz discutindo a modernidade, pois, esta a seu ver, nos remete ao cotidiano. Desse modo, traça as diferenças entre o projetado e o vivido, o primeiro versando sobre a racionalidade, a base do imaginário técnico que representa o ideário central da modernidade; e o segundo sobre o discurso dos moradores, baseado no vivido, no cotidiano, nas experiências de vida que se desenvolvem no limite da necessidade, ou que se dilatam, enfim, no limite - tudo aquilo a que a modernidade não respondeu e que está em sua "periferia", emsua orla (p.17).

Para ele:

Se de um lado o que estabelecia a dinâmica entre a vida das pessoas no novo lugar de morar era o cotidiano, do outro, era o pensamento técnico que norteava as concepções que embasaram as novas políticas habitacionais da Superintendência de Habitação Popular. Colocava-se assim a dicotomia entre o mundo técnico e o mundo vivido. Tal constatação nos remeteu de imediato para as reflexões sobre o processo de desenvolvimento da modernidade, recolocando a questão onde a aparente divergência entre os dois mundos vislumbrados convergiam, ou melhor, dinamizaram-se, na verdade, numa única lógica, ou em um único processo imposto por esta modernidade ${ }^{110}$. (op. cit, p.36) ${ }^{111}$.

É fácil perceber a divergência entre o mundo técnico e o mundo vivido assinalada pelo autor. No entanto, queremos chamar a atenção para o fato de que justamente os ideais técnicos da modemidade expressos na territorialidade construída nas áreas de implantação dos conjuntos, influenciam diretamente na vida cotidiana e nas práticas socioespaciais dos

\footnotetext{
110 Grifo nosso.

111 O autor dedica importante parte de sua pesquisa para a discussão da relação entre modernidade e cotidiano. SOUZA, Gustavo de Oliveira C. Do projetado ao vivido, a construção do lugar. O meio ambiente na produção de conjuntos habitacionais. Tese de Doutorado. Departamento de Sociologia - IFCH/UNICAMP. Campinas, 1997; apoiando-se em autores como Edward Soja (1993), David Harvey (1993), Agnes Heller (1985), Michel Maffesoli (1978,1984 e 1994), Antony Giddens (1991), Jurgen Habermas (1987,1991).
} 
moradores dessas áreas. Daí a convergência do que parece divergente. Um processo é resultado e resultante do outro. Ainda para esse autor, as reflexões sobre a modernidade remetem a um debate central que se instaura no interior das ciências sociais, expresso pela polêmica da superação da modernidade pela pós-modernidade, ou seja, um debate que se dá no interior da razão modema e não fora dela. Tal polêmica aponta para uma crise estrutural nas ciências sociais que vê seus alicerces - fundados na razão - abalarem-se por uma crescente leitura dos aspectos "irracionais" nas estruturas societárias contemporâneas ${ }^{112}$. Es no nosso entender o respaldo do estudo do cotidiano.

Antogiovanni (2005) preocupa-se com os embates entre as modernizações no campo (solicitadas em nome do "desenvolvimento" 113) e as manifestações de resistências de comunidades tradicionais ocorridas nos territórios cotidianos. Podemos inferir que a modernização no campo é também proveniente da modernidade? Souza (1997) traz para o debate aspectos da "teoria da modernidade" de Habermas, onde esse autor diferencia modernização e modernidade como segue: a modemização "tratase de uma racionalização ocorrida nos subsistemas econômico e político; enquanto que a modemidade cultural é um movimento de autonomização no interior do mundo vivido, das chamadas 'esferas de produção': a moral, a ciência e a arte"114. (apud Souza, 1997, p.38). Para Habermas modemidade cultural e modernização societária são dois aspectos da modernidade, sem os quais esta não pode ser compreendida115.

Vimos brevemente como se relacionam modernidade e cotidiano. O que converge para nosso debate, no sentido de esclarecer que o cotidiano como conceito e categoria de análise, é um advento da sociedade urbana e, portanto, é uma construção social de um dado espaço e tempo específico.

Carlos Vainer (2005), trazendo para o debate a mobilização e a imobilização das pessoas na contemporaneidade, identifica a pressão porque passa a academia no sentido de produzir novos conceitos, novas idéias, novas teorias e questiona até que ponto o que é novo e o que é novidade no debate acadêmico. Para isso, apresenta dois tipos de novidade: um primeiro que diz respeito a novos fatos sociais, como por exemplo, novas leis ou novos contratos sociais de migração que passam a denominar, ver, e analisar de maneira diferente um

\footnotetext{
112 Idem. Grifos do autor.

${ }^{113}$ No âmbito de sua pesquisa tal modernização é incitada pela Aracruz papel e celulose no Estado do Espírito Santo. ANTOGIOVANNI, Lídia Lúcia. Territórios reticulados e os constrangimentos aos territórios do cotidiano. In: Anais do X Encontro de Geógrafos da América Latina. Universidade de São Paulo. São Paulo, 2005. p. 1018 a 1030.

114 Grifos do autor.

115 Idem.
} 
mesmo grupo de indivíduos que vive as mesmas dinâmicas e processos desde sempre: trabalhos clandestinos, empregos ilegais, etc. $\mathbf{O}$ segundo tipo de novidade, diz respeito a um processo de reconfiguração da nossa capacidade perceptiva: como se determinados processos ou práticas presentes desde há muito tempo na realidade social viessem à tona. Para o autor, esses novos olhares podem decorrer do surgimento de movimentos políticos e culturais que sinalizam ou denunciam dimensões antes não perceptíveis e não percebidas.

A partir disso, cabe o questionamento: o estudo do cotidiano como categoria de análise é uma dimensão em algum momento da história não perceptível e sempre esteve presente na realidade social e o que mudou foi justamente nossa capacidade de interpretar/perceber tal fato? Ou corresponde ao primeiro tipo de novidade sinalizado por Vainer? Odete Seabra (2004) ajuda a responder as questões. Para ela, o que atualmente estudamos e entendemos como cotidiano é o que os clássicos da ciência geográfica (Max Sorre, La Blache, Pierre George, Jean Brunhes) denominaram de gênero de vida. A autora reconhece que à época desses clássicos, as derivações conseguidas atualmente com o estudo cotidiano não eram possíveis. Isto porque, o cotidiano que estudamos atualmente somente pode ser analisado à luz da modernidade.

Desse modo, interpretamos o cotidiano como o primeiro tipo de novidade proposto por Vainer, ou seja, o cotidiano como novo fato social regido pela modernidade, que o diferencia sobremaneira dos gêneros de vida, tão ricamente analisados pelos geógrafos clássicos.

Voltemos agora nossa atenção para Henri Lefebvre e suas formulações sobre o cotidiano.

3.3 Henri Lefebvre e a vida cotidiana no mundo moderno.

A conturbação provocada pela Segunda Guerra Mundial, e a proposta de mudar a conduta das pessoas para que eventos de tais proporções não voltassem a ocorrer, motivaram iniciativas consideradas potencialmente capazes de instigar a mudança da vida diária das pessoas. A reflexão sobre a vida cotidiana era uma delas. A partir de então, o cotidiano apareceu com maior intensidade na literatura filosófica, como categoria a ser revista e aprofundada, pois, era necessário superar o idealismo e buscar mudar a vida, de modo geral, a partir da mudança da vida cotidiana. Assim, em lugar de reconstruir a sociedade francesa em crise, porque não utilizar essa profunda crise para "mudar a vida"? Lefebvre reconhece a frustração de sua ambição, mas foi justamente a partir desse contexto que o autor passou a discutir sistematicamente o cotidiano e o eleva a condição de temática da filosofia. A obra Indroduction 
à critique de la vie quotidienne ${ }^{116}$ foi escrita em 1946 após o fim da ocupação alemã na França, e sua intenção era ir mais além buscando o global - a totalidade -, ao invés de se deter nos pormenores, nas diferenças entre grupos e classes, apenas no sentido comum.

Já vimos que esse autor interpreta a vida cotidiana como surgida com a instituição da modernidade e edifica seu estudo do cotidiano partindo das representações que são feitas a ele. Em A vida cotidiana no mundo moderno, o autor utiliza-se do romance Ulisses de James Joyce para analisar as mudanças ocorridas no cotidiano do mundo urbano moderno na primeira metade do século XX. Escolhe um dia (16 de junho de 1904) e faz a incursão do modo como esse dia foi vivido por Leopold Bloom, por sua mulher Molly e por seu amigo Stephen Dedalus, protagonistas do romance ${ }^{117}$. É esse "cenário" que Lefebvre analisa, inclusive as relações dos personagens com um lugar, no caso a cidade de Dublin, "Esta cidade é apropriada para os que habitam nela; os moradores de Dublin modelam o seu espaço e são modelados por ele. $O$ homem inseguro que parece errar pela cidade, reúne fragmentos e aspectos dispersos desta dupla apropriação"118.

E justifica sua escolha por Joyce

O tempo(...) com sua fluidez e sua continuidade, com sua lentidão (cheia de surpresas e de suspiros, de debates e de silêncios, suntuosa, monótona e variada, tediosa e fascinante), é o fluxo heraclitiano sem cortes, principalmente entre o cósmico (objetivo) ou o subjetivo. A história de um dia engloba a do mundo e a da sociedade. (p.8)

Em sua análise de Ulisses, o autor navega sobre um cotidiano composto por referências a um lugar; composto também pelas pluralidades de sentido (o literal, o próprio, o figurado, o analógico, o simbólico, o oculto, o metafísico, o místico, etc); bem como pelas diferenças de níveis no discurso; o familiar, o histórico, o próximo e o longínquo. Tais sentidos não aparecem na obra a cada vez, mas coexistem (p.9). E registra assim, a rica complexidade de um cotidiano vivido no início daquele século, e daí parte para chegar às mudanças empreendidas nele, meio século depois, argumentando o "ataque" ao cotidiano por outro caminho: o da filosofia.

Lefebvre faz uma observação de que, no século XIX, a reflexão deixa a especulação para se aproximar da realidade empírica e prática, dos "dados" da vida e da consciência e que, a

116 Em A vida cotidiana no mundo moderno o autor faz um parêntese em relação aos três volumes da Critique de la vie quotidienne. O primeiro editado em 1946, o segundo em 1963. A vida cotidiana no mundo moderno traz o que há de essencial no terceiro volume e deixa de lado segundo o próprio autor bom número de fatos e argumentações. 117 Ulisses de James Joyce é considerada por leitores, estudiosos, e críticos literários como obra fundamental da literatura universal no século XX (publicação original de 1922), pela riqueza narrativa, pela técnica empregada a essa narrativa fugindo à sintaxe e a gramática tradicionais e pela associação de sua obra a Odisséia de Homero. 118 (1991, p.11). 
obra de Marx e as ciências sociais nascentes nessa época, delineavam esse traçado.

Importante assinalar que Henri Lefebvre ainda que filósofo, faz uma crítica à filosofia pois, para ele é impossível colocar frente a frente o homem da filosofia e o homem do cotidiano, isto porque, a filosofia lhe traz uma consciência e um testemunho decisivos, porquanto ela é a crítica ao mesmo tempo vã e radical do cotidiano. Para ele, a manutenção da tradição filosófica é um obstáculo para qualquer projeto que se pretenda transformador e, acredita que o conceito da cotidianidade provém da filosofia e não pode ser compreendido sem ela, designando o não filosófico para e pela filosofia. O conceito de cotidianidade não vem do cotidiano nem o reflete: ele exprime antes de tudo a transformação do cotidiano vista como possível em nome da filosofia. Mas não provém dessa ciência isolada, nasce dela que reflete sobre a não filosofia. $\mathrm{E}$ considera:

O cotidiano não seria apenas um grau inferior da reflexão e do "vivido". Tampouco somente uma experiência, interpretação de baixo nível filosófico. Seria algo mais: não uma queda vertiginosa, nem um bloqueio ou obstáculo, mas um campo e uma revocação simultânea, uma etapa e um trampolim, um momento composto de momentos (necessidades, trabalhos, diversão - produtos e obras - passividade e criatividade - meios e finalidades, etc), interação dialética da qual seria impossível não partir para realizar o possível (a totalidade dos possíveis) (1991, p. 19 e 20) $)^{119}$

Possíveis realizados a partir de pequenos nadas, pequenos detalhes que unidos num projeto ambicioso formam ou podem transformar a práxis cotidiana.

Ainda relacionando o homem de filosofia e o homem cotidiano, Lefebvre anuncia:

O filósofo procura se fechar na sua especulação e não consegue. O homem cotidiano se fecha em suas propriedades, seus bens e suas satisfações, e às vezes se arrepende. Ele está ou parece estar mais próximo da natureza do que o sujeito da reflexão ou da cultura. E muito mais a mulher cotidiana: mais capaz de cólera, de alegria, de paixão e de ação, mais vizinha das tempestades, da sensualidade, dos laços entre a vida e a morte, das riquezas elementares e espontâneas. Mas isso é verdadeiro ou falso, aparente ou real, superficial ou profundo? (idem, p. 23).

A vida cotidiana ocultaria o misterioso e o admirável que escapariam aos sistemas elaborados.

Para o autor, no cotidiano tudo é contado, desde o dinheiro até os minutos. Tudo se enumera, desde os objetos até as pessoas. Há muito tempo a tirania da "enumeração" tomou conta da humanidade! Desde o momento em que somos muitos, em que nomes não bastam para nos diferenciar. Daí a combinação de muitos números para garantir nossa individualidade,

119 Grifos do autor. 
nossa exclusividade, a certeza de que somos únicos, mesmo que sejamos semelhantes no que diz respeito a nomes, sobrenomes, aparência física. Daí o Cadastro de Pessoa Física, Registro Geral, Título de Eleitor, Registro Acadêmico. Todos expressos por tiranos números!!! Não bastasse enumerar as pessoas, enumera-se também tudo que se refere às suas propriedades: telefones, placa e chassi do automóvel, casas, blocos, andares, apartamentos. As referências aos lugares de moradia não são mais os acidentes geográficos: o morro, o riacho, o vale, a mata, mas símbolos da urbe (construções, praças) sempre relacionados às enumerações: $1^{\text {a }}$ à esquerda na altura do no 3100 de certa rua ou avenida, ao lado de certa praça.

É no cotidiano que as pessoas ganham ou deixam de ganhar sua vida, num duplo sentido: não sobreviver ou sobreviver, apenas sobreviver ou viver plenamente. É no cotidiano que se tem prazer ou se sofre. Apenas sobrevive o indivíduo desempregado, à espera de melhores dias, de auxílio do vizinho, do benefício da prefeitura e que vive no limite de seus recursos. Vive plenamente a juventude a descobrir inúmeras possibilidades de compartilhar experiências, de desafiar a velocidade, o medo, a insegurança, de transgredir as regras, os contratos sociais estabelecidos. É no cotidiano que se felicita a chegada de novos filhos, mas com muito pesar se aceita a perda dos entes queridos. Por isso o prazer e o sofrimento inerentes ao cotidiano.

Em relação à sociedade, esta constitui o conjunto de base, estrutura e superestrutura. Em que a base constitui-se através do trabalho produtor de objetos e de bens materiais; a estrutura constituída por relações sociais estruturadas, estruturantes, determinadas pela base e determinando relações de propriedade; e as superestruturas constituídas pelas elaborações jurídicas (códigos, instituições (Estado), ideologias). (1991, p.36).

Eleger o estudo da vida cotidiana implica considerar a relação entre esses três níveis para a análise da sociedade, ainda que não tenhamos a estudado como um todo, pois acreditamos que o indivíduo, ou grupos de indivíduos, nesse caso os moradores dos conjuntos habitacionais, são sempre entidades sociais e, conseqüentemente "alegorias" vivas daquilo que representam, ou seja, a sociedade. A vida cotidiana pode ser definida como lugar de equilíbrio, mas também de desequilíbrio entre esses níveis, daí ser por isso mesmo, lugar da práxis como sugere Lefebvre.

O autor apreende a cotidianidade, se importando com suas características, tendo em vista as determinações das relações sociais de produção e o movimento de sua reprodução, como assinalamos anteriormente.

Ainda em relação à sociedade cabe trazer para o debate sua formulação de sociedade a partir da qual 0 autor desenvolve seus estudos sobre o cotidiano. 
O autor "experimenta" várias definições: sociedade industrial, sociedade tecnocrática, sociedade da abundância, sociedade do lazer, sociedade do consumo e apresenta argumentos para refutá-las 120:

Sociedade industrial ou sociedade técnica: Inspirando-se em Saint-Simon, os sociólogos lançam a denominação de "sociedade industrial". E de fato verificam que a produção industrial, com suas implicações (papel cada vez maior do Estado e da racionalidade organizadora), não pára de crescer, pelo menos nos grandes países modernos. A indústria não completa a agricultura; a produção industrial não coexiste pacificamente com a produção agrícola: ela a absorve.

Não podemos deixar de reconhecer o caráter determinante da técnica, presente em nossas vidas mesmo quando não percebemos. A fotografia, o rádio, a TV, etc... A crítica do autor, tem o sentido de localizar as mediações da alta complexidade da vida social, possível pela técnica e a produção de ideologias, valores, conjuntos de signos e de significações muitas vezes rivais do que pretende a técnica. Ea opção pelo meio urbano encontra argumentação no que diz respeito aos locais de realização das técnicas. Para o autor, fora do urbano, a técnica produz apenas objetos isolados, como por exemplo, um foguete, ou um radar. Cabe um posicionamento em relação a essa questão, na medida em que mesmo fora do urbano, a técnica está presente e de nenhuma maneira produzindo objetos isolados. Referimo-nos às usinas de beneficiamento, tratores, pivôs de imigação etc... Dinamizando a produtividade da agricultura, às vezes distantes do meio urbano, mas nem por isso isolado dele. $\mathrm{E}$ a indústria não completa nem absorve a produção agrícola, mas a complementa. Os estudos da relação campo-cidade rechaçam veementemente essa posição.

Nem mesmo um radar, é um objeto isolado. Sabemos da importância para o meio urbano de um radar em órbita no espaço.

Sociedade tecnocrática: (..) os tecnocratas agindo pelo caminho da organização e da instituição. Sua racionalidade teria fins e meios específicos. O termo usado então seria "sociedade tecno-burocrática", o que anularia todo o prestígio da definição, pois para o autor a tecnocracia não existe: não passa de um mito e de uma ideologia.

120 Página 58 e seguintes de Henri Lefebvre (1991). 
Sociedade da abundância: A produção industrial e a "tecnicidade" permitiriam entrever uma produtividade sem limites, com a automatização das atividades produtoras. Para a infelicidade da definição (vindas dos ideólogos da sociedade americana, Galbraith, Rostow) a automatização acarretaria um certo número de consequêencias que a refreariam.

Para Lefebvre a automatização exagerada e a abundância acarretariam a passagem à gratuidade dos produtos industriais verdadeiramente abundantes, afetando o fundamento do valor de troca, essencial para a manutenção do sistema capitalista.

Sociedade do lazer: A grande mudança, a transição a caminho' ${ }^{121}$, não seria tanto a passagem da escassez para a abundância quanto à passagem do trabalho para o lazer. Trocaríamos de era, de "valores" dominantes, uma mudança difícil. Às fadigas da "vida moderna" tornar-se-iam indispensáveis o divertimento, a distração, a distensão. Os teóricos do lazer, seguidos por uma legião de jornalistas e vulgarizadores, já teriam dito e repetido: as férias, fenômeno recente em toda a escala social, modificaram essa sociedade, deslocaram as preocupações, tornando-se o centro destas.

Nesse momento Lefebvre classifica o uso do tempo. O tempo obrigatório (o do trabalho profissional), tempo livre (o dos lazeres), o tempo imposto (o das exigências diversas fora do trabalho, como transporte, idas e vindas, formalidades). Dentre eles, Lefebvre verificou 0 aumento do tempo imposto que, para ele, aumenta mais rápido que o tempo dos lazeres. $\mathrm{O}$ tempo imposto se inscreveria na cotidianidade e tenderia a definir o cotidiano pela soma das imposições (o conjunto delas). Na verdade, os valores antigamente ligados ao trabalho, ao ofício, ao qualitativo na ação criadora se dissolveriam. Os valores ligados ao lazer estariam começando a nascer. (...) O não - trabalho conteria o futuro e seria o horizonte, mas a transição se anuncia longa, confusa e perigosa ${ }^{122}$. Somente uma automatização integral da produção tornaria possível a sociedade dos lazeres. 0 trabalho continua a dominar a prática social.

A respeito do trabalho dominando a prática social, podemos traçar um paralelo entre Henri Lefebvre e Agnes Heller, uma vez que esta última reconhece que em diferentes épocas uma ou outra atividade cotidiana: trabalho, vida privada, ou lazer, predomina na vida dos homens ${ }^{123}$.

\footnotetext{
121 À época em que o livro foi escrito.

122 Grifo nosso.

123 (1992, p.18) em que a autora discute a hierarquia da vida cotidiana, ou seja, as dimensões cotidianas não ocupam ao mesmo tempo a mesma importância na vida cotidiana.
} 
Escrita há meio século, a atualidade das reflexões de Henri Lefebure é impressionante! Hoje percebemos nitidamente o aumento do tempo imposto, e para tanto basta lembrarmos do tráfego intenso de veículos nas grandes cidades e também as más condições dos transportes coletivos e infra-estrutura viária, além das distâncias entre os lugares que comprometem sobremaneira o aumento do tempo imposto. Outro exemplo são as imensas filas necessárias na resolução de qualquer espécie de burocracia: serviços bancários, saúde pública, previdência social etc. Em relação ao tempo dos lazeres, embora se reconheça sua necessidade e haja na contemporaneidade uma indústria do turismo, do consumo, do lazer, que atinge determinada parcela da população, por outro lado, nas áreas periféricas das cidades e em São Paulo não é diferente, o tempo do lazer diminui e quando existe, é sim como sugere Henri Lefebvre o espetáculo.

Olazer não é mais a Festa ou a recompensa do labor, também não é ainda a atividade livre que se exerce para si mesmo. É o espetáculo generalizado: televisão, cinema, turismo.

Sociedade de consumo. Segundo Lefebvre (op.cit, p.62), essa denominação difundiu-se no período entre 1950 a 1960, pois houve aumento do consumo de bens materiais e culturais. De acordo com ele, existiu efetivamente uma passagem da escassez à abundância, da produção insuficiente à um consumo imenso e mesmo à um superconsumo (desperdício, gastos com suntuosidade e prestígio, etc.) nos ambientes do capitalismo modificado, mas essa passagem, como as outras transições, ocorre de maneira penosa, arrastando consigo algo do passado, sob a influência de imposições pouco claras. (...) É a ideologia do consumbi24. Por isso essa definição também não é aceita por ele.

Que o leitor não se perca! Estamos reconstruindo o caminho feito por $\mathrm{H}$. Lefebvre até chegar a uma definição de sociedade em que se assente o cotidiano.

Sociedade burocrática de consumo dirigido. Eis a definição acolhida pelo autor.

O cotidiano no mundo moderno, deixou de ser "sujeito" (rico de subjetividade possível) para se tornar "objeto" (objeto da organização social). Enquanto objeto da reflexão, longe de desaparecer (o que poderia ter acontecido se o movimento revolucionário tivesse obtido sucesso), ele, ao contrário, se reafirmou e se consolidou. Nessas condições, as denominações propostas não parecem aceitáveis. Como segurar e juntar num enunciado os traços levados em consideração? "Sociedade burocrática de consumo dirigido", tal é a definição proposta aqui para nossa sociedade. Marcam-se assim tanto o caráter racional dessa sociedade, como também os limites dessa racionalidade (burocrática), o objeto que ela organiza (o consumo no lugar da produção) e o plano para o qual dirige seu esforço a fim de se sentar sobre: 0 cotidiano. (op cit, p. 68) 125

124 Grifos do autor.

125 Grifos do autor. 
E alerta para a relativização de tal definição, pois essa não é em absoluto dogmática, plena, inteira, pois se o fosse destruiria toda esperança e fecharia qualquer abertura. (p.84)

Consumo dirigido pelo poder da mídia, das facilidades de crédito, do "inconsciente" coletivo e das falsas necessidades' ${ }^{126}$. Tamanho é o consumo, que se consome até e inclusive o objeto capaz por suas inovaçães tecnológicas de desperdiçar, diminuir, interromper as mais simples das habilidades humanas. Todavia, as inovações tecnológicas possibilitam também às pessoas desenvolver outras habilidades.

Em nome da tecnologia, andar ainda que seja por um curto percurso é substituído por dirigir, reutilizar ou reaproveitar é substituído por consumir o novo, e nisso o descartável é duplamente ameaçador, pois faz desaparecer a ação de lavar para novamente poder usar, além de incitar sempre mais consumo, na medida em que o descartável traz como principal pressuposto o rejeito. Preparar um alimento (do mais simples ao mais sofisticado) é substituído por comprar pronto. ${ }^{127}$ Dirigir-se ao aparelho eletro-eletrônico a fim de lhe programar, é substituído pelo leve acionar do botão de um controle remoto. Na sociedade burocrática de consumo dirigido, a tirania da substituição perpassa os produtos alimentícios, e os pequenos objetos. Há que se substituir o imóvel, o automóvel, os móveis, as roupas, enfim... Ainda que a vida útil destes esteja longe do fim.

A afirmação de Seabra (1996) corrobora nossa reflexão:

o cotidiano, ele próprio, é uma mediação entre o econômico e o político, objetivação de estratégias do Estado no sentido de uma gestão total da sociedade; lugar de realização da indústria cultural visando os modelos de consumo, no que se destaca o papel da mídia. (p.77).

Lefebvre assinala ainda que:

126 "Você é tapeado por múltiplas miragens ao trazer os seus significados aos significantes evanescentes, imagens, objetos, palauras - e os seus significantes aos significados, declamaçōes e dedarações, propagandas pelas quais Ihe indicam aquilo em que você deve acreditar e o que deve ser. Assim, se você deixa passar sobre si as nuvens de signos, pela televisão, pelo rádio, no cinema, na imprensa, e se ratifica os comentários pelos quais outros fixam para você o sentido desses signos. Então você será a vítima passiva da situação". (1991, p.31)

127 Um passeio sem compromisso a uma feira livre nos dias atuais faz perceber que mesmo entre aqueles que se dispõem preparar seus alimentos (dos mais simples aos mais sofisticados) a comodidade, e a rapidez incitadas pela modernidade começam a mudar alguns hábitos de comerciantes e consumidores, assim abacaxis, cebolas, alhos são vendidos descascados, verduras picadas e lavadas, carnes, peixes e aves são vendidos limpos, e cortados ao gosto dos fregueses, "prontos" para o preparo. Ressaltamos que todos esses alimentos são adquiridos dessa maneira, pois serão acondicionados em um potente aparelho refrigerador, já que na maioria dos casos, todo o "excesso" ou o que "não presta", e que foi tirado pelo feirante, serve muitas vezes para a proteção e sobrevida dos alimentos. As feiras livres que outrora serviam como lugar de sociabilidade e troca em espécie entre pessoas de uma localidade, hoje são somente lugares de troca através da moeda nas grandes cidades, haja vista a impossibilidade do cultivo de alimentos e criação de animais nas habitações modernas em virtude da inabilidade das pessoas e da redução do espaço das habitações. 
Não é o consumidor nem tampouco o objeto consumido que têm importância nesse mercado de imagens, é a representação do consumidor e do ato de consumir, transformado em arte de consumir ${ }^{128}$. Ao longo desse processo de substituição e de deslocamento ideológicos, conseguiu-se afastar e até apagar a consciência da alienação, acrescentando-se alienações novas às antigas. (p.62)

É o momento de trazermos à tona a elaboração deste autor no que tange aos subsistemas constituintes do cotidiano. De maneira breve este autor lembra que alguns teóricos (que ele não chega a citar), consideram que os subsistemas "são códigos parciais por meio dos quais a sociedade existente se organiza e organiza a cotidianidade segundo uma ordem ou ordens próximas: o morar e a moradia, a mobilia, o horóscopo, o turismo, a cozinha, a moda, todas atividades parciais que dão lugar a publicações, tratados, catálogos, guias". (p.84). Para ele, tais teóricos limitam-se a si mesmos e não questionam a ordem distante, omitindo assim a ausência do código geral. Adiante Lefebvre apresenta sua própria formulação dos subsistemas.

Parte de uma "crítica" aos teóricos estruturalistas quando empregam o termo sistema de maneira vaga e imprecisa. Supondo que exista mais que um sistema, cada um deles não tem mais que uma existência e uma importância relativas. Nenhum deles pode isolar-se. Daí sua proposição para adotar o termo subsistema.

Para que existam são precisos:

(a) Atos, uma atividade (social) distinta, especificada ou especializada. Objetos que correspondam a uma atividade, isto é, específicos, suscetíveis, por isso de serem organizados, classificados, etiquetados.

(b) Organizações e instituições, estas legalizando aquelas, ao nível do Estado ou de outra instituição ligada ao Estado. A instituição opera em cima desse "material", a organização, que por sua vez, opera em cima da atividade social.

(c) Textos (...) que garantem a comunicação da atividade, a participação nas medidas que a organizam, a influência e autoridade das instituições correspondentes. Esses textos podem já constituir um código, mas podem também consistir em documentos, tratados, manuais, guias, imagens ou escritos publicitários dos quais o corpus e o código explícito serão extraídos por análise. (p.109)

De acordo com tal definição, a moda é um subsistema, assim como a cozinha, o turismo, o automóvel. E a publicidade? Também seria um subsistema? Examinemos sucintamente cada um dos subsistemas apresentados por Henri Lefebvre.

128 Grifo nosso. 
A moda? Perguntamos quantas mulheres seguem a moda? Um punhado de manequins, de personalidades olímpicas. E elas mesmas tremem de medo de não estar mais na moda, pois são elas que a fazem, e a moda lhes escapa ao controle assim que é lançada, e elas têm de encontrar outra moda. (p.113)

A esse respeito cabe assinalar o caráter tirânico da moda, e o modo como por isso mesmo, ainda que não desejemos, estamos na moda. Ao procurar substituir uma roupa ou acessório do vestuário que por ter envelhecido, quebrado, etc... não serve mais, como por exemplo (uma calça, um sapato, uma bolsa), somos arrebatados por um sem-número de peças que estão na moda, e que por isso mesmo, será encontrado em toda e qualquer loja que se vá. A dificuldade se constitui em querer substituir uma peça por outra igual ou similar, pois ouvimos: "Assim você não encontra mais, agora só temos este que está na moda". Entre procurar aquilo que sabemos não mais encontraremos e o que está na moda, muitas vezes só nos resta a última opção. A opressão da moda vai mais além, passando pelo vestuário, a cor do esmalte, o corte de cabelo, a cor e o material de que são feitos novos móveis, até às relações interpessoais ${ }^{129}$. E não estar na moda em qualquer das dimensões assinaladas implica a não aceitação na sociedade através do riso, do escárnio, do estranhamento.

Em relação à cozinha Lefebvre se pronuncia:

Esta se torna um subsistema ao perder seu antigo estatuto de produção local, artesanal e familial, qualitativa, feita de receitas transmitidas oralmente - para se tornar atividade formalizada, especializada, matéria para tratados, guias "gastronômicos", para uma hierarquia de lugares, de iguarias, pretexto de uma ritualização mundana. $(p .109)^{130}$

Chamamos a atenção para a especialização da cozinha como espécie de sociabilidade entre as pessoas ao redor de todo o mundo, uma vez que sair de casa para um almoço ou jantar em um lugar especializado, é um programa apreciado por toda a sociedade contemporânea. Eis o pretexto da ritualização mundana de que nos alerta Lefebvre. Daí a diversificação da cozinha: fast-foods, praças de alimentação, restaurantes simples, sofisticados, exóticos, típicos, variados, self-service, à la carte. Até bem pouco tempo atrás, para usufruir tamanha diversificação, o indivíduo obrigatoriamente deveria sair de casa em direção a um restaurante, ou estabelecimentos similares. Assistimos hoje a outros arranjos, cuja possibilidade é desfrutar das especialidades no lugar onde se está: casa, escola, trabalho, sem a necessidade de enfrentar trânsito, filas, contato com outras pessoas, etc... Daí o sistema delivery. Para aqueles que estão

129 No que respeita às relações interpessoais basta lembrar a postura das pessoas no que se refere a virgindade ou ao casamento em tempos pretéritos e como se dão esses mesmos "contratos sociais" atualmente.

130 Grifo do autor. 
dentro do automóvel e não desejam sair, há também uma possibilidade: fazer o pedido de dentro do próprio automóvel, onde também poderão (e essa é muitas vezes a intenção) comer. No que diz respeito à produção dos alimentos, esta é cada vez menos atividade espontânea, criadora, conhecimento transmitido através de gerações ${ }^{131}$. A ideologia do consumo e das facilidades também contribui para que não o seja, tantos são os fomos para rápido preparar; os aparelhos para melhor cortar, picar, triturar; os refrigeradores para aumentar a sobrevida do preparado. Mais que isso, é fundamental ressaltar a diminuição do espaço da cozinha e do tempo de cozinhar na contemporaneidade como impedidores da atividade de cozer num amplo sentido.

O turismo não foi considerado exatamente como subsistema, mas em vias de se constituir como tal na sociedade de consumo. No entanto, não podemos deixar de assinalar sua consideração de que "O turismo destrói e depois se destrói. O turismo destrói o lugar turístico pelo simples fato de atrair multidões" (p.113).

Já o automóvel é avaliado como o Objeto-Rei do mundo moderno, invasor da cotidianidade, pois rege múltiplos comportamentos em diversos domínios, da economia ao discurso (op.cit, 110). Para esse objeto, há inúmeros atos, instituições, e textos (tríade necessária na constituição de um subsistema) para referendá-lo.

O automóvel com seus mortos e feridos, com as estradas sangrentas, é um resto de aventura no cotidiano, um pouco de prazer sensível, um pouco de jogo. Interessante notar o lugar do carro no único sistema global que descobrimos: a estrutura dos álibis. Álibi para o erotismo, álibi para a aventura, álibi para o "habitar" e para a sociabilidade urbana, o Automóvel é uma peça desse sistema que cai em pedaços assim que 0 descobrimos. (p.111) ${ }^{132}$

Da elaboração dos subsistemas podemos levar em conta ainda a publicidade. Se pensarmos nos três elementos essenciais para sua existência (atos, instituições e textos), poderíamos considerá-la também um subsistema Todavia, Lefebvre a sugere como "uma linguagem da mercadoria levada à mais alta elaboração, dotada de uma expressão simbólica, de uma retórica, de uma metalinguagem" e não como um subsistema. (p.114)

Não caberia questionar se a publicidade não seria mais que uma linguagem ou metalinguagem, mas um sistema de subsistemas? Estamos partindo do pressuposto de que na modernidade tudo passa por ela, em outras palavras, tudo se publica, desde interesses públicos

131 É disso que nos fala Luce Giard em Morar, Cozinhar - 2º tomo de A invenção do Cotidiano. Tradução: Ephraim F. Alves e Lúcia Endlich Orth. Petrópolis: Vozes, 1996.

132 Grifo do autor. 
coletivos, até a vida privada deste ou daquele ${ }^{133}$. Basta para isso pensar na divulgação concernente à moda, a cozinha, ao turismo, ao automóvel, ou a qualquer subsistema, somente possível através dos textos (terceiro elemento para se constituir um subsistema) publicitários. Ressaltamos que no âmbito desta formulação, estamos considerando publicidade de modo amplo e não de modo "restrito" das agências e profissionais publicitários.

Claro está que os subsistemas não estão separados, ou fragmentados no âmbito do cotidiano, mas coexistem.

Partimos das contribuições de $A$ vida cotidiana no mundo modemo para apresentar como o percurso teórico de Henri Lefebvre se desenvolveu no que tange às suas perspectivas ao que podia ou "ainda" pode a vida cotidiana.

Conforme já assinalamos nesse trabalho, o cotidiano chegou a ser pensado por Lefebvre como propulsor de uma mudança de vida na obra Crítica da vida cotidiana.

Em A vida cotidiana no mundo moderno esse autor considera que para "fugir" do peso do cotidiano há que recorrer a uma revolução cultural permanente. Segundo ele, esse conceito está implícito no pensamento de Marx, explícito nas obras de Lênin e de Trotski. Não seria o caso de tomar a revolução cultural chinesa como referência, visto que a China, país essencialmente agrário (à época em que foi escrito o livro), passou por processos muito específicos. A revolução cultural que Lefebvre incita não pode ser ascética.

Não é a revolução a partir de uma cultura, menos ainda para e pela cultura. Đa não pode pretender encarnar no real e na prática social uma cultura, justamente quando a nossa cultura se fragmenta, se esmigalha, se decompõe no moralismo, no estetismo e na ideologia da técnica. Essa dissolução apareceria melhor se a "cultura" não tivesse uma função terrorista bem definidali34.(...) Nossa revolução cultural tem como fim e sentido a criação de uma cultura que não seja instituição, mas estilo de vida. Ela se define primeiro pela realização da filosofia no espírito da filosofia. (p.214)

Pouco adiante:

A restituição da obra e do sentido da obra não tem um objetivo "cultural", mas prático. De fato, nossa revolução cultural não pode ter finalidades simplesmente "culturais". Ela orienta a cultura em direção a uma prática: a cotidianidade transformada. A revolução muda a vida, não apenas o Estado ou as relações de propriedade. Não tomemos mais os meios como fim! Isso se enuncia desta maneira:

133 Segmento inclusive bastante polêmico da imprensa expressa aqui pela publicidade de revistas e programas televisivos especializados em notícias e informações da vida privada de outrem.

134 Grifos do autor. 
"Que o cotidiano se torne obra! Que toda técnica esteja a serviço dessa transformação do cotidiano!" (p.215) ${ }^{135}$

Em suma, a revolução cultural proposta por esse autor se daria em três dimensões simultâneas: a)Reforma e revolução sexual, b)Reforma e revolução urbanas, c)A festa reencontrada.

Em artigo escrito em 1973 e publicado no Brasil em 1985136, Lefebvre reconhece a ambigüidade de suas interpretações:

(...)É fácil denunciar, vinte e cinco anos mais tarde, uma certa ambigüidade na Crítica da vida cotidiana (1946, primeira edição, Grasset). Livro alusivo? A quê? À cultura? Aos "tempos livres"? À realidade urbana? Sem dúvida. O alusivo implicava o que devia explicitar-se. A ambigüidade permitiu as interpretações mais desencontradas: extremistas (a revolução na e pela vida cotidiana, tudo e já imediatamente) e reformistas (melhorar o estatuto do cotidiano, a qualidade da vida). Também não impediu a crítica: a crítica "direitista" pela cientificidade que se pretende pura - a crítica "esquerdista" pela ação que se pretende dura ${ }^{137}$.(p.230)

Tais sinalizaçães têm intenção de explicitar como o debate sobre o cotidiano é complexo, trazendo em seu bojo transformações no âmbito da história, capazes de fazer mudar o percurso teórico de seus próprios propositores ${ }^{138}$.

A Revolução Urbana também importa para o debate, pois esta obra faz parte dos estudos sobre a vida cotidiana e da produção do espaço produzidos pelo autor ${ }^{139}$. Por meio dela continuamos nossa linha de raciocínio no que diz respeito à denominação da sociedade atual. Isto porque se em $A$ vida cotidiana no mundo modemo a definição Sociedade burocrática de consumo dirigido era suficiente para compreender sua complexidade, em A Revolução Urbana, estudo posterior, tal acepção ganha novos elementos para serem analisados. A hipótese levantada pelo autor é a urbanização completa da sociedade. Daí o novo termo empregado por ele - Sociedade urbana, a sociedade que resulta da urbanização completa e que nasce da industrialização. Para o autor, não se pode considerar cidade qualquer cidade grega, oriental ou medieval. Não há como compará-las, e por isso não é possível denominá-las como sociedade urbana (denominação reservada para a sociedade nascida da industrialização). (1999,p.15)

\footnotetext{
135 Grifos do autor.

136 Ver nota 7.

137 Grifos do autor.

138 Conforme ele mesmo verificou que a partir de modificações na vida social seus "objetos" se dissipavam sob seus olhos ou se modificavam até o ponto de se tornar irreconhecíveis. (1991, p. 47)

${ }_{139}$ Ressaltamos, no entanto, a advertência do próprio autor sobre a leitura "fragmentada" de suas obras. Para ele o conjunto de sua obra constitui um fluido único, e buscou restituir a teoria de Marx em toda sua integridade e amplitude (...) depois de um século de transformações. (Cf nota do tradutor Sérgio Martins no prefácio à edição brasileira, editada pela UFMG em 1999. Edição original de 1970).
} 
São palavras do autor, referindo-se a ele mesmo:

Pôde-se falar de sociedade industrial e, mais recentemente, de sociedade pósindustrial, de sociedade técnica, de sociedade de abundância, de lazeres, de consumo etc. Cada uma dessas denominações comporta uma parcela de verdade empírica ou conceitual, de exagero e de extrapolação. Para denominar a sociedade pós-industrial, ou seja, aquela que nasce da industrialização e a sucede, propomos aqui este conceito: sociedade urbana, que designa, mais que um fato consumado, a tendência, a orientação, a virtualidade. Isso, por conseguinte, não tira o valor de outra caracterização crítica da realidade contemporânea como, por exemplo, a análise da "sociedade burocrática de consumo dirigido" ${ }^{140}$. (op. cit. p.16)

Para ele, através e no interior da "sociedade burocrática de consumo dirigido", a sociedade urbana é um projeto, não está pronta, mas em constante gestação. Vejamos que um conceito não anula o outro, mas 0 complementa. ${ }^{141}$

Em sua discussão sobre o campo cego que há entre o rural, o industrial e o urbano, o que olhamos não é exatamente o que enxergamos, pois mesmo percebendo perspectivas diferentes, não podem ver, nem conceber, percursos múltiplos, espaços complexos. Não podem saltar do cotidiano - fabricado segundo as coações da produção industrial e do consumo dos produtos da indústria - para o urbano, que se libertaria desses determinismos e coações ${ }^{142}$.

A realidade urbana, antes de nascer e de se afirmar, se vê reduzida, de um lado, pelo rural (os subúrbios compostos por casas ajardinadas, os espaços ditos verdes) e de outro, pelo cotidiano industrial (as moradias funcionais, as vizinhanças, as relações, os trajetos monótonos e obrigatórios), cotidianidade submetida às exigências das empresas e tratada conforme a racionalidade empresarial. Trata-se de uma redução, ao mesmo tempo social e mental, de um lado, à trivialidade e, de outro, à especialidade ${ }^{143}$. (1999, p.38).

No capítulo IV da obra em questão, Henri Lefebvre alega que a análise do fenômeno urbano depende de noções metodológicas já conhecidas: dimensões e níveis. Para ele, essas noções permitem introduzir uma certa ordem nos confusos discursos que dizem respeito à cidade e ao urbano. E indica três níveis para essa análise.

São eles: o nível global (G), o nível misto (M), e o nível privado (P).

\footnotetext{
140 Grifos do autor.

141 "O urbano é o possível, definido por uma direção, no fim do percurso que vai em direção a ele". (Grifos do autor) (op. cit. p.28)

142 Grifos do autor.

143 Grifos do autor
} 
No nível global (G) se exerce o poder, o Estado, como vontade e representação. Como vontade: o poder de Estado e os homens que detêm esse poder têm uma estratégia ou estratégias políticas. Como representação: os homens de Estado têm uma concepção política ideologicamente justificada do espaço. (op.cit, p.78).

As políticas de provisão de habitação sejam elas federais, estaduais ou municipais, são bons exemplos desses poderes e dessas estratégias legitimadoras de certa produção do espaço.

O nível misto $(M)$ é o nível intermediário entre o nível $G$ e o nível $P$. É o nível especificamente urbano. O nível da "cidade", na acepção corrente do termo. (...) O conjunto especificamente urbano apresenta a unidade característica do "real" social, o agrupamento: formas-funções-estruturas. A esse respeito pode-se falar de duplas funções (na cidade e da cidade: funções urbanas relacionadas ao teritório circundante e funções internas) ${ }^{144}$. (op. cit., p.80).

São os especuladores imobiliários, a iniciativa privada responsável pelos serviços e comércios urbanos. Essenciais para a vida na cidade, qualquer que seja seu tamanho e magnitude.

No nível privado $(P)$ só o domínio edificado pode ser considerado: os imóveis (habitações: grandes prédios de apartamentos, casas, acampamentos e favelas) ${ }^{145}$ (p.80). É o nível onde o cotidiano é mais facilmente percebido, onde se produzem e reproduzem-se as relações sociais elas mesmas e também as relações sociais de produção, conforme já assinalamos.

A oposição habitar, habitat é fundamental para compreendermos a apropriação dos indivíduos com os lugares de morar, necessariamente no nível P. Certos de que voltaremos a esse debate apresentamos suas diferenças. O habitat seria tão somente o espaço concebido para a habitação. Nesse caso trata-se da concepção por agentes do Estado (nível G) ou agentes imobiliários (nível M). Seriam as máquinas de morar (idealizadas por Le Corbusier) onde os habitantes restringir-se-iam aos elementares atos de comer, dormir, reproduzir-se. Em contraposição, o habitar seria a poesia implicada no ato de morar. Nas palavras de Lefebvre: (...) a relação do "ser humano" com a natureza e com sua própria natureza, como "ser" e seu próprio ser, reside no habitar nele se realiza e nele se lê. (op cit, p.81) ${ }^{146 .}$

\footnotetext{
144 Grifos do autor.

145 Nesse momento Lefebvre adverte que a oposição habitar, habitat fora fruto de longa controvérsia, no entanto, consideramos a pertinência de apresentá-la.

146 Grifos do autor.
} 
Tal oposição nos interessa, isto porque, na área objeto desse estudo, resultado e resultante que é do nível $\mathrm{G}$, influenciados pelos ideais modernistas das máquinas de morar, e na prática, âmbito do nível P; preocupa-nos entender qual a relação entre os indivíduos moradores e suas habitações. Como e se habitam como poetas, os apartamentos e as casas pretensamente funcionais.

Com preocupações didáticas, Lefebvre apresenta separadamente os três níveis de análise do urbano, uma vez que no complexo exercício de pensar e viver na cidade, tais níveis estão interpenetrados. Impossíveis de serem separados na prática.

A ordem próxima, presente no nível $\mathrm{P}$, e, portanto, na vida cotidiana, recebe a todo 0 tempo influências da ordem distante, presente no nível $\mathrm{G}$, intermediadas pelo nível $\mathrm{M}$.

Podemos abstrair daí também, que a ordem próxima é a dimensão do vivido e em seu contraponto, a ordem distante é a dimensão do concebido.

Em coletânea sobre a contribuição da ordem próxima e a ordem distante, a partir do pensamento lefebvriano Limonad \& Lima (2003) explicitam:

É na inter-relação entre a reprodução do cotidiano e da totalidade que podemos encontrar os primeiros traços da correlação entre uma ordem próxima e uma ordem distante, que interagem, entre si - na medida em que historicamente, mesmo antes do capitalismo, a reprodução da família (relações sociais de reprodução) interferiria na divisão social do trabalho e na organização social (relações de produção) e vice versa (...) (p.23).

Lefebvre citado pelos mesmos autores adverte que, ao mesmo tempo em que o espaço carrega em si simbolismos sexuais explícitos ou clandestinos (representações das relações de reprodução) próprios do cotidiano, do particular e do vivido, transmite também as mensagens hegemônicas do poder e da dominação (representações das relações sociais de produção) expressões do geral e do concebido. (p.24).

Na perspectiva de pensar uma estratégia urbana, Lefebvre acredita que a crítica que a vida cotidiana alcança poderá surpreender. Por isso, não pode ser considerada como um aspecto menor da sociologia. Já nos posicionamos sobre essa questão nas primeiras páginas deste trabalho.

Não é um determinado "objeto" que ela [a vida cotidiana] ${ }^{147}$ estuda criticamente, tampouco determinado "sujeito"; ela não tem um domínio delimitado. Ela não se utiliza tanto da economia e de análises econômicas, quanto da sociologia, da psicologia, da lingüística. Reciprocamente, ela não pode ser enquadrada em

\footnotetext{
147 Inserção nossa.
} 
nenhuma dessas classificações. É certo que ela não abarca o conjunto da práxis da época industrial, mas dela retém resultados essenciais. Essa época teve o seguinte resultado: a constituição de uma cotidianidade, lugar social e uma exploração refinada e de uma passividade cuidadosamente controlada. A cotidianidade não se instaura no seio do 'urbano' como tal, mas na e pela segregação generalizada: a dos momentos da vida, como a das atividades. O procedimento crítico comporta a crítica dos objetos e sujeitos, dos setores e domínios. Mostrando como as pessoas vivem, a crítica da vida cotidiana instala o ato de acusação contra as estratégias que conduzem a tal resultado ${ }^{148}$. (1999, p.129) ${ }^{149}$

Em De Lo Rural a Lo Urbano, Henri Lefebvre critica os doutrinários que afimam que a vida cotidiana é simplesmente um detalhe, uma modalidade superficial da sociedade capitalista, e que segundo eles, não pode dar lugar a nenhum conceito. Contra eles se pode afirmar que nem a vida cotidiana e nem a sociedade urbana constituem uma pura e simples superestrutura, expressão das relações de produção capitalista. Fazem parte de um mesmo processo.

Para Lefebvre é no mundo da mercadoria, com sua lógica e sua linguagem, que se generaliza o cotidiano. Posteriormente, 0 autor destaca que a era urbana não faz desaparecer as contradições da era industrial, pelo contrário, estas se agravaram e para isso, o autor apresenta o exemplo da dinâmica da segregação socioespacial, das diferentes formas de centralidade, entre outros.

Lefebvre também procura dar ênfase às diferentes maneiras de pensar e refletir sobre a cidade, a questão do geógrafo em relação ao sociólogo e, desse em relação ao urbanista, revelando a necessidade de pensarmos na totalidade em nossas análises mesmo quando partimos do local, como por exemplo, a rua ou o bairro. Para ele, somente o método dialético permite contemplar o todo. É interessante destacar que o referido autor aponta uma proposição: de que a cidade projeta sobre o terreno uma sociedade, uma totalidade social, compreendendo sua cultura, instituições, ética, valores, mediante uma base econômica e as relações sociais que constituem a superestrutura. Assim, na cidade se materializam obras, que são os monumentos, edifícios públicos e privados, constituindo os chamados símbolos.

Ainda considera que tal proposição reforça um estudo sociológico mediante a intensidade das ações dessas dbras no espaço (as instituições, a cultura, a ética e os valores), constituindo também "atos sociais".

Dentro dessa perspectiva, é um erro subestimar o bairro, que sabemos ser uma parte que reflete o todo. E que ele só existe nas cidades em função de uma história, ou seja, de um

148 Grifo nosso.

149 Grifos do autor. 
tempo. Perder a rua não é só perder um objeto concreto, vivo, dotado de certa vida, é perder de vista que a cidade é uma fonte de informação ininterrupta.

Informação que decorre a partir de como os sujeitos decifram a pertença de morar em certa rua, certo bairro. Recentes discussões relativas a sociabilidades urbanas de modo um tanto saudosista, rechaçam qualquer possibilidade da vida de bairro no mundo urbano moderno. Todavia, se consideramos o cotidiano como uma dimensão que totaliza espaço e tempo na contemporaneidade, há que ponderá-lo justamente mediante as transformações que podem explicar a ausência da "vida de bairro".

A "vida de bairro" teria findado, em alguns fragmentos de bairros das cidades, onde algumas residências levam para traz o quintal (local de sociabilidade), em detrimento de deixar livres suas frentes para guardar nas garagens o "objeto rei" da modernidade (o automóvel), que pela mobilidade que proporciona, faz com que os moradores usufruam e tenham acesso a outros bairros da cidade, por outro lado, ao nos referirmos à faixa de menor renda da população, a vida de bairro ainda ocorre e seus baixos rendimentos contribuem para explicar tal possibilidade.

Em primeiro lugar, assinalamos para a representação que os sujeitos têm dos lugares em que moram no que respeita à arquitetura de suas residências. Notamos a partir de observações em campo, que a identidade vinculada com as pessoas passa primeiro pela identidade com os padrões de construção das habitações. É como se o padrão das construções desse "pistas" sobre as origens, valores, gostos das pessoas. Daí a aproximação e as relações mais sólidas entre aqueles que moram em habitações parecidas (tanto no entorno do Conjunto Habitacional Parque Continental, como também dentro dele). Os muros e limites que o separa do restante do bairro, faz emergir uma identidade que não está relacionada num primeiro momento com as pessoas, mas com o lugar. São comuns falas de mães para seus filhos: "brinquem só aqui dentro" (referindo-se às ruas constituintes do Conjunto), como se somente pertencessem àquele fragmento do bairro e não ao bairro todo.

Outro aspecto que relaciona a "vida de bairro" com o baixo rendimento dos moradores do Conjunto Habitacional, diz respeito aos trabalhos e ocupações. Já assinalamos que muito se faz dentro do empreendimento. No entanto, é bastante expressivo o número de moradores que trabalham muito perto dali, ou ali mesmo. As principais argumentações sobre tal fato é a impossibilidade de procurar emprego mais longe por falta de recursos. E os parcos expedientes que recebem como rendimento, não permitem o pagamento das tarifas do transporte público. Ademais, o tempo imposto dos transportes coletivos e tráfego intenso na cidade também são considerados na procura por trabalho ou ocupação. Desse modo, se moram ali e trabalham perto, é natural que se apropriem verdadeiramente do bairro, freqüentando o shopping dos 
arredores, a feira livre do entorno, comércio e serviços do centro do bairro, além de escolas, posto de saúde, etc. Ess a vida de bairro, redesenhada, modificada, numa dimensão menor, mas ainda presente.

Tentamos até aqui, o exercício de "reconstruir" 150 o pensamento de Henri Lefebvre no que diz respeito às suas preocupações com a vida cotidiana. Mostramos como as relações de produção e reprodução e os fenômenos urbanos estão intimamente relacionados e fazem parte dessa preocupação. Que esse esforço tenha alcançado resultado!!!

3.4 Habitar X habitat: vivendo no Conjunto.

Recuperamos aqui a oposição proposta por Lefebvre habitar/habitat para compreendermos a maneira de morar do nosso território cotidiano, analisado no nível privado.

O habitat corresponde ao espaço concebido para a habitação. Em contraposição, o habitar corresponde à poesia implicada no ato de morar. Dito de outra forma, o habitat está para "propriedade efetiva", assim como o habitar para "apropriação afetiva" com o espaço habitado.

No dizer de O. Seabra, a insurreição do uso' ${ }^{151}$ no pensamento lefebvriano diz respeito ao uso do espaço, do tempo, do corpo, essencialmente porque abrigam dimensões da existência: o prazer, o sonho, o desejo, o riso. Daí nosso interesse pelas noções revisadas pela autora de apropriação e propriedade. A primeira tendo como referência qualidades, atributos, usos, portanto; e a segunda relacionada a quantidades, a comparações quantitativas, igualações formais, portanto, troca.

É preciso assinalar de antemão que não há pelos moradores uma percepção única quanto ao lugar de morar. Dessa maneira são referências a este espaço: Conjunto, Comunidade, Nosso bairro, Predinhos, COHAB, Mutirão. Este último aparecendo com mais freqüência, mas é necessário frisar que Mutirão refere-se nesse caso à totalidade do Conjunto Habitacional e não somente às casas construídas em regime de mutirão no âmbito do Programa de Produção de Unidades Habitacionais em Mutirão e Autogestão da administração de Luiza Erundina.

150 Cientes da vastidão de sua obra, os trabalhos escolhidos para nossa investigação respondem às nossas perspectivas, pelo menos nesse momento de nosso percurso intelectual.

${ }^{151} \mathrm{~A}$ insurreição do uso. In MARTINS, José de Souza (org). Henri Lefebvre e o retorno à dialética. São Paulo: Hucitec, 1996. 
Os muros de concreto que margeiam o Conjunto, trazem em sua extensão propagandas políticas, mas também propagandas de comércios e serviços das áreas próximas dali. São extensões dos muros que margeiam o terreno baldio ao lado do Conjunto.

Adentrando o Conjunto pela Rua Peixe Boi, temos acesso à Rua Sabiá Branco, conhecida pelos moradores como "Primeira rua", vemos do lado esquerdo em toda a extensão da rua, a enorme fileira de casas autoconstrúidas, todas assobradadas, todas com recuo de frente e de fundo, a maioria com portões e garagens feitas pelos moradores (à margem do que propunha o projeto original), todas com a mesma pintura externa nas cores ferrugem e laranja ${ }^{152}$, em algumas delas há a presença de pequenas árvores e ou plantas, em toda a extensão da rua muitos carros estacionados, de um e de outro lado, de propriedade dos moradores do mutirão e dos moradores dos prédios, também enfileirados, com pintura externa marfim e detalhes azuis situados no lado direito da rua Nas outras duas ruas, Quica D’Água, e Quero Quero, "Segunda" e "Última rua", respectivamente, os outros prédios que compõem o empreendimento aparecem também enfileirados, pintados da mesma forma com a cor marfime detalhes azuis. Nessas ruas, há também a presença de inúmeros carros estacionados, pois, são poucas as áreas dos edifícios inicialmente destinadas a estacionamento que cumprem essa função. Além disso, é necessário considerar a facilidade em adquirir um automóvel atualmente, o que explica também o número elevado de veículos nas ruas do empreendimento. Na maioria dos edifícios, nas áreas previstas para estacionamento, o que há são parcas construções onde funcionam as atividades de comércio e senviços do Conjunto Habitacional: desde os tradicionais bares e salões de cabeleireiro, até brechó, açougue, bicicletaria, oficina mecânica para o conserto de automóveis etc ${ }^{153}$. Uma moradora lembra-se do início das ocupações das áreas de estacionamento:

No começo ninguém tinha carro, então ninguém ligava para o estacionamento. A verdade é essa. Daí um mais esperto foi lá e fez uma garagem, outro também fez. Agora todo mundo tem carro, mas o estacionamento já está tomado. Não tem mais vaga, e quando tem uma para vender, eles vendem por 2 ou 3 mil reais. Fora o comércio né? Daí agora vários moradores têm carro novo, mas não tem lugar, ficam estacionados na rua, as crianças brincam com bola, pega nos carros, chega até a disparar alarme.

Um ou outro prédio está cercado por grades e portões, mas constituem a minoria deles.

152 A exceção de duas, cujos moradores fazem questão de manter o aspecto cinza dos blocos, em protesto aos conflitos quando da ocupação de quatro das casas prontas conforme apresentamos no primeiro capítulo. Quando todas as famílias receberam tinta da prefeitura para efetuar a pintura, essas quatro famílias não receberam, duas delas, no entanto, utilizaram-se de recursos próprios para acompanhar o padrão externo de todas as outras casas do Mutirão.

153 Ver foto 6 (p.135). 
No final da Rua Sabiá Branco, onde outrora funcionava o Centro Comunitário das casas autoconstruídas por mutirão, atualmente há um aglomerado de casas também autoconstruídas, mas diferentemente das primeiras, sem auxílio da Prefeitura Municipal, sem apoio técnico, sema solidariedade dos demais moradores. Segundo uma moradora de uma dessas casas, a assistência social da Prefeitura a orientou a ocupar dois cômodos do Centro Comunitário até que seu problema de moradia fosse resolvido, uma vez que ela passava por problemas de relacionamento com a sogra com quem morava. Seu caso nunca foi resolvido, e ao saberem da ocupação dos cômodos do Centro Comunitário por essa moradora, outras pessoas dividiram a área restante e passaram a construir ali casas de um ou dois cômodos. O mesmo aconteceu com a área contígua ao antigo Centro Comunitário e próxima à quadra de futebol154. A observação do croqui abaixo permite uma noção geral do empreendimento, nele também estão mapeadas todas as ocupações irregulares.

Na Rua Quero-Quero outro Centro Comunitário (construído por ocasião da edificação dos edifícios do Projeto Cingapura) está em funcionamento. Além de eventuais velórios e reuniões, acontece semanalmente a celebração de um culto evangélico no local. Motivo pelo qual os pastores responsáveis pelo culto e também os moradores freqüentadores reivindicam junto à Prefeitura Municipal a construção de uma igreja evangélica "oficial" para o Conjunto155. O croqui abaixo nos dá a noção da área do Conjunto Habitacional Parque Continental atualmente.

154 Não sabemos quantas casas há nessa área do Conjunto, no entanto, os moradores fazem uma estimativa de uma dezena de casas.

155 Vale acrescentar que já existe uma Igreja Evangélica no Conjunto, em virtude da ampliação de uma das casas do mutirão. Seus freqüentadores são moradores tanto do mutirão como dos prédios do Cingapura. 


\section{Localização dos blocos e ocupações irregulares}

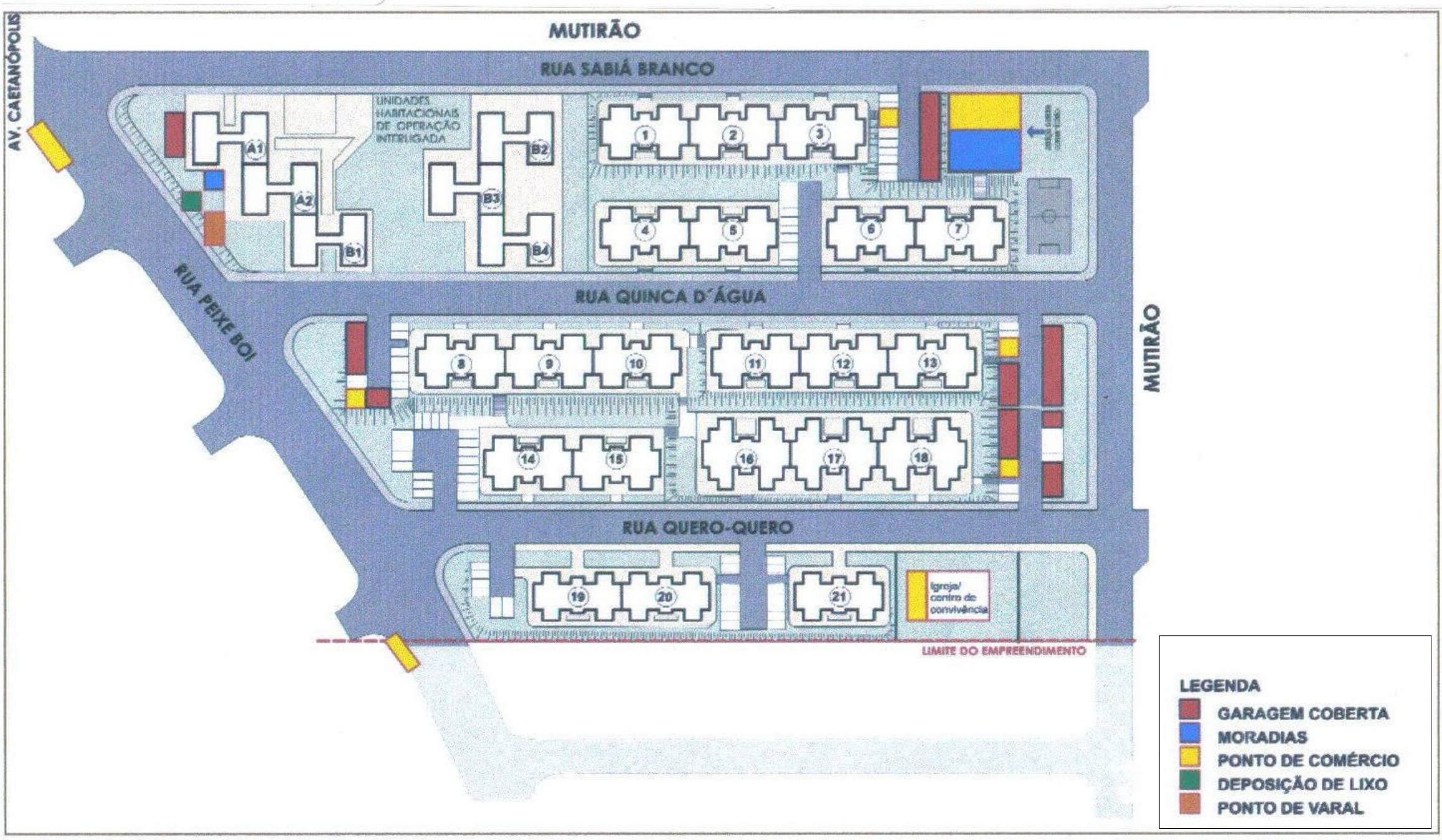

Base:Prefeitura do Município de São Paulo. Secretaria de Habitação e Desenvolvimento Urbano - SEHAE Superintendência d a $H$ abitação Popular - HAB F o nte: D i a g nós $t i c o l g t$ e g r a d o, 200 


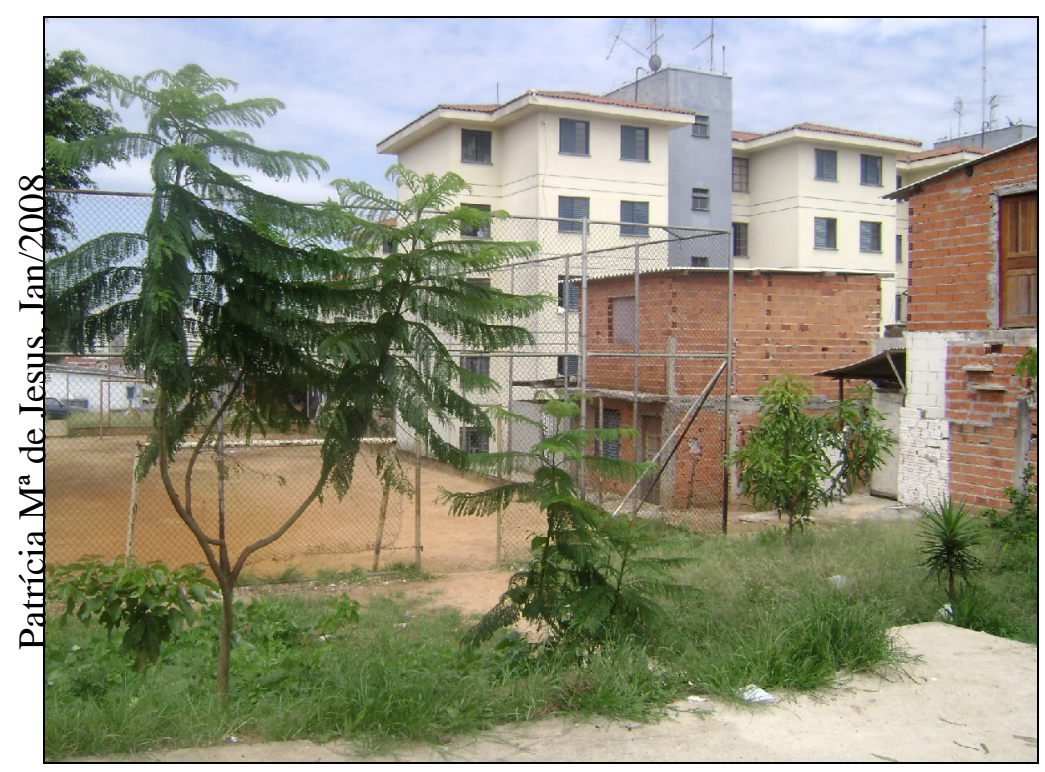

Foto 5: Área do Centro Comunitário do Mutirão invadida por algumas famílias, e a quadra de futebol do Conjunto. Em segundo plano, prédios Cingapura e em último plano, no canto superior esquerdo Centro Comunitário dos prédios Cingapura.

Doravante, examinaremos com maior atenção a vida cotidiana do Conjunto Habitacional Parque Continental, verificando como exatamente ocorre a apropriação do espaço do Conjunto por seus moradores, antes, porém, apresentaremos as contribuições de Agnes Heller ${ }^{156}$ para nosso estudo.

Em suas pesquisas sobre a vida cotidiana, Heller (1989, p.17) busca situar o conceito de vida cotidiana no conjunto das relações do ser humano com a sociedade. Para ela, toda sociedade tem uma vida cotidiana e todo homem, seja qual for o lugar por ele ocupado na divisão social do trabalho, tem uma vida cotidiana. Assim se expressa a autora:

A vida cotidiana é a vida de todo homem. Todos a vivem, sem nenhuma exceção, qualquer que seja o seu posto na divisão do trabalho intelectual e físico. Ninguém consegue identificar-se com sua atividade humano-genérica a ponto de poder desligar-se inteiramente da cotidianidade. E, ao contrário, não há nenhum homem, por mais 'insubstancial' que seja, que viva tão-somente na cotidianidade, embora essa 0 absorva preponderantemente. ${ }^{157}$

É a vida do homem inteiro, ou seja, o homem participa na vida cotidiana com todos os

${ }^{156}$ Agnes Heller desenvolveu estudos sobre o cotidiano, dos quais deteremos atenção em o Cotidiano e a História e Sociologia de la Vida Cotidiana (ambas publicadas originalmente em 1970). Aluna e colaboradora de Gyorgy Lucaks (Pensador húngaro idealizador da Escola de Budapeste de orientação marxista) baseava-se nas teorias marxistas para suas análises, buscando subsídios para elaborar uma teoria da vida cotidiana.

157 Grifo da autora. 
aspectos de sua individualidade, de sua personalidade. Nela, colocam-se "em funcionamento" todos os seus sentidos, todas as suas capacidades intelectuais, suas habilidades manipulativas, seus sentimentos, suas paixões, idéias, ideologias. O fato de que todas as suas capacidades se coloquem em funcionamento determina também, naturalmente, que nenhuma delas possa realizar-se, nem de longe, em toda sua intensidade. $\mathrm{O}$ homem da cotidianidade é atuante e fruidor, ativo e receptivo, mas não tem tempo nem possibilidade de se absorver inteiramente em nenhum desses aspectos, por isso não pode aguçá-los em toda sua intensidade. (p.17)

A vida cotidiana é, em grande medida, heterogênea, e isso sob vários aspectos, sobretudo no que se refere ao conteúdo e à significação ou importância de nossos tipos de atividade. São partes orgânicas da vida cotidiana: a organização do trabalho e da vida privada, os lazeres e o descanso, a atividade social sistematizada, o intercâmbio e a purificação. (p.18).

De acordo com ela, a vida cotidiana além de heterogênea é também hierárquica e essa hierarquia não é eterna e imutável, mas se modifica de modo específico em função das diferentes estruturas econômico-sociais. O trabalho nem sempre ocupou lugar dominante na estrutura da vida cotidiana, pois em tempos pré-históricos toda ela se constituía em torno do lazer, da atividade social.

A vida cotidiana não está fora da história, mas no centro do acontecer histórico: é a verdadeira "essência" da substância social (p.20) (Grifo da autora).

A característica dominante da vida cotidiana é a espontaneidade. (...) A espontaneidade caracteriza tanto as motivações particulares (e as formas particulares de atividade) quanto as atividades humano-genéricas que nele têm lugar. O ritmo fixo, a repetição, a rigorosa regularidade da vida cotidiana (que se rompem quando se produz a elevação acima da cotidianidade) não estão absolutamente em contradição com essa espontaneidade, ao contrário, implicam-se mutuamente. (...) Mas a espontaneidade não se expressa apenas na assimilação do comportamento consuetudinário e do ritmo da vida, mas também no fato de que essa assimilação faz-se acompanhar por motivações efêmeras ${ }^{158}$, em constante alteração, em permanente aparecimento e desaparecimento. (p.30)

$\mathrm{Na}$ vida cotidiana, o homem atua sobre a base da probabilidade ${ }^{159}$, da possibilidade: entre suas atividades e as conseqüências delas, existe uma relação objetiva de probabilidade. Jamais é possível, nesta vida, calcular com segurança científica a conseqüência possível de uma ação. Nem daria, visto a riqueza das atividades. (ibidem)

Na obra Sociologia de la Vida Cotidiana, Agnes Heller (1994, p.19) explicita melhor o

158 Grifos da autora.

159 Grifos da autora. 
conceito de vida cotidiana ao aprofundar a distinção entre as atividades voltadas para a reprodução do homem singular160 e, aquelas voltadas para a reprodução do social do seguinte modo:

Para reproduzir a sociedade é necessánio que os homens particulares se reproduzam a si mesmos enquanto homens particulares. A vida cotidiana é o conjunto de atividades que caracterizam a reprodução dos homens particulares, os quais, por sua vez, criam a possibilidade de reprodução do social. ${ }^{161}$

A heterogeneidade é uma das características das atividades cotidianas: constituem-se nas múltiplas atividades rotineiras necessárias para a reprodução humana. O indivíduo, ao nascer, se depara com determinados tipos de relações e de atividades sociais que já estão hierarquicamente estabelecidas, desde as que são socialmente consideradas imprescindíveis para a vida em sociedade até as consideradas prescindíveis. Por conseguinte, para fazer parte do meio em que vive, o ser humano precisa assimilar um sistema de referências próprio desse ambiente, um conjunto de relações e atividades consideradas necessárias à sua autoreprodução por aquele contexto social. Tais atividades heterogêneas, não requerem do indivíduo uma direção consciente, na medida em que são desenvolvidas de forma "espontânea e natural", sem que o homem tenha noção do processo através do qual as assimila.

As atividades não-cotidianas, ao contrário, são aquelas que servem à reprodução do gênero humano como um todo e, conseqüentemente, servem também à reprodução do homem particular. Trata-se da esfera da vida humana em que se desenvolvem a ciência, a arte, a filosofia, etc. Para alcançá-la, o homem precisa estar em relação consciente com a atividade que realiza, bem como com o objeto dessa atividade, diferentemente daquilo que ocorre com as atividades cotidianas que são assimiladas e realizadas de forma "natural e espontânea", não consciente. Assim, enquanto estas se caracterizam pela "naturalidade e espontaneidade", as atividades não-cotidianas se caracterizam pela intencionalidade.

Cumpre ressaltar ainda que o significado do conceito de vida não-cotidiana se explicita na sua relação com o conceito de vida cotidiana e se define a partir dele. A vida não-cotidiana requer a intencionalidade (uma relação consciente com o conteúdo e a forma das atividades, próprias dessa esfera mais "elaborada" da vida humana). Assim, são raros os casos dos

\footnotetext{
160 Heller, na sua obra Sociología de la vida cotidiana, utiliza-se da expressão homem singular para referir-se a todo homem. Segundo a autora, o homem singular, sendo simultaneamente ser particular e ser genérico, pode tender tanto para a particularidade como para a genericidade. Para referir-se à predominância da particularidade no ser humano, Heller utiliza-se da expressão homem particular, e, para referir-se à predominância da genericidade, utilizase da expressão indivíduo, distinções essas que não estão claras na versão espanhola aqui utilizada. Neste trabalho o emprego da palavra indivíduo refere-se indistintamente a todo ser humano, adjetivando-a quando necessário. ${ }^{161}$ Grifo nosso. As citações da obra Sociología de la vida cotidiana, 1994, foram por nós traduzidas.
} 
indivíduos que conseguem superar os limites da particularidade (que é um dos pólos constitutivos de sua individualidade) e dirigir suas ações prioritariamente para o humanogenérico (para o outro pólo que constitui a sua individualidade - a genericidade), ou seja, para as atividades que estão diretamente voltadas para a reprodução da sociedade. É preciso esclarecer, porém, que não é possível traçar um limite rígido entre o comportamento cotidiano e o comportamento não-cotidiano (a elevação ao humano-genérico), pois todo indivíduo é, simultaneamente, ser particular e ser genérico ${ }^{162}$.

Heller aborda o significado do não-cotidiano de modo a ressaltar sempre a passagem da cotidianidade para a genericidade, nas várias dimensões da vida humana em sociedade, tais como o trabalho, a política, a moral, a ciência e a filosofia. Desse modo, ao tratar das características do cotidiano que se manifestam nas várias dimensões da vida, como, por exemplo, a heterogeneidade, a espontaneidade, o pragmatismo e a hipergeneralização, a autora as relaciona com as do não-cotidiano que rompem com os limites destas características da vida cotidiana: a homogeneização, a intencionalidade, a reflexão e a causalidade.

Apoiando-se em Lukács, a autora (op. cit, p. 27) afirma que, para ultrapassar os limites da heterogeneidade da vida cotidiana e promover a elevação do homem particular ao humanogenérico, garantindo o processo denominado homogeneização, se faz necessária a combinação simultânea de três fatores, a saber: a concentração de toda a atenção do homem particular sobre uma única tarefa; a suspensão de qualquer outra atividade durante a execução da tarefa escolhida; e o emprego da inteira individualidade humana na resolução da referida tarefa.

O indivíduo, na sua vida social, tem a possibilidade de identificar-se tanto com a esfera do cotidiano quanto com a esfera do não-cotidiano. A grande maioria das pessoas, porém, a vive dentro dos limites da esfera cotidiana, dadas as relações sociais que as condicionam ao exercício de diversas atividades restritas do âmbito cotidiano. Tais atividades absorvem grande parte do tempo e energia do indivíduo, fator que lhe impossibilita intensificá-las uma a uma.

Vejamos como isso se dá na prática.

162 Suas preocupações, seu modo de relacionar-se com o mundo e com as coisas estão ligados às suas aspirações individuais, particulares que dizem respeito a si mesmo, também e concomitantemente são aspirações genéricas, de todo homem, como por exemplo, o trabalho socialmente necessário para reproduzir-se. 


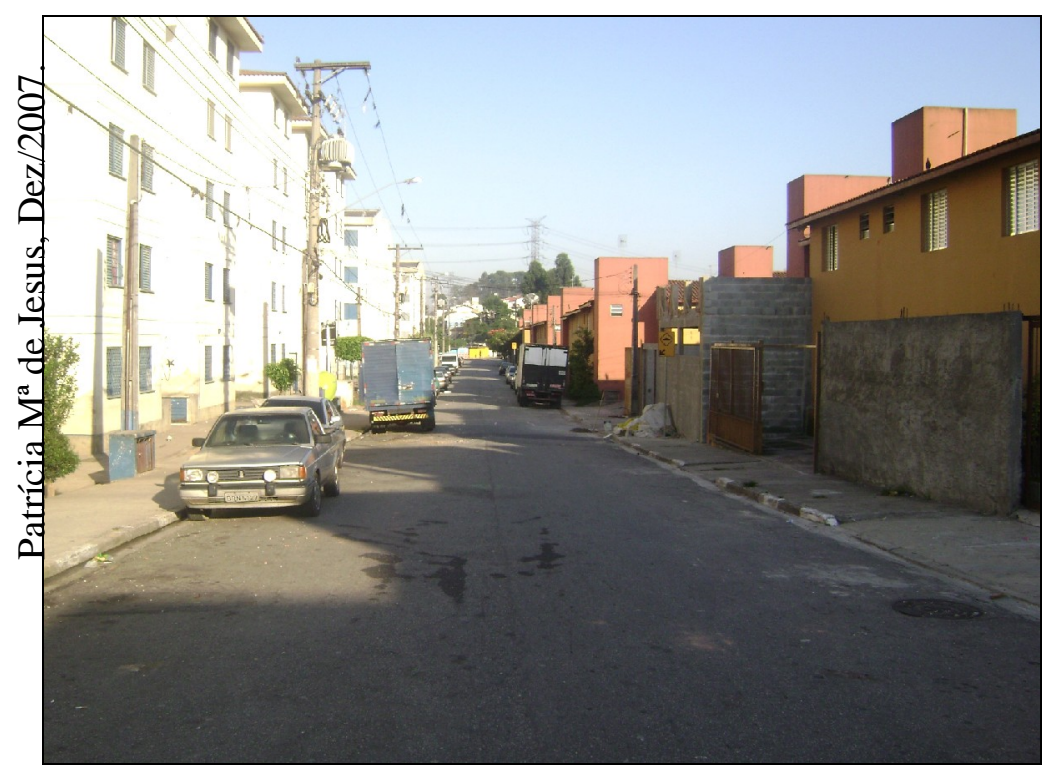

Foto 6: Panorâmica do Conjunto: do lado esquerdo edifícios Cingapura e do lado direito casas do Mutirão. Note-se uma das casas em reforma.

\subsection{0 movimento da rua.}

São comuns nas ciências humanas, análises que contrapõem o sentido e a apropriação da rua nas áreas residenciais da população de maior renda e das áreas residenciais da população de menor renda, em que naquelas é cada vez mais comum a ausência de pessoas em qualquer que seja o horário do dia ou o dia da semana, e nessas, a presença constante de indivíduos nas ruas, em qualquer hora, em qualquer dia. À medida que avança a semana, aumenta também a quantidade de pessoas nas ruas, quando aos finais de semana crianças, jovens e adultos lotam as vias das áreas periféricas das cidades.

Observando a permanência dos moradores nas ruas do Conjunto, desvendamos que o movimento das ruas é incitado pela presença das pessoas, e paradoxalmente, a permanência das pessoas nesse espaço é incitada pelo movimento das ruas.

Em Carlos (1996, p. 90) encontramos diversos sentidos para as ruas nas grandes cidades: passagem, mercado, festa, reivindicação, moradia, território de domínio de gangues, normatização da vida (através de placas, semáforos etc.), segregação socioespacial, encontro. 
Contudo, se levamos em consideração as ruas das áreas periféricas das cidades, notamos também um outro sentido da rua: aquele da permanência. Trata-se do sentido de simplesmente ficar/permanecer na rua, sem que para isso haja um motivo específico. Mas é preciso ressaltar, que muitas vezes as razões da permanência são urgentes, necessárias, ainda que aos olhos desatentos pareça banal e menor.

As crianças (especialmente os meninos), sem espaço adequado para as brincadeiras tomam conta da rua, assim como a rua toma conta delas. Desse modo, a rua é ideal para o pega-pega, bolinha de gude, futebol, o teste do alcance e velocidade dos carninhos, o encontro para ir à lan-house do "lado de fora" do Conjunto, à barraca de jogos eletrônicos ali mesmo no espaço do Conjunto, onde na barraca ao lado consegue-se o "cigarro solto"163 da mãe, que deseja mesmo ter os filhos na rua, pois não é possível, lavar, cozinhar, e limpar a casa, com eles por ali, pois, o espaço diminuto da casa não acolhe todos ao mesmo tempo, ainda mais quando os móveis não estão nos lugares planejados para eles , mas no meio da casa por ocasião da limpeza. Quando existe necessidade de manusear figuninhas ou cards para jogar ou trocar os "repetidos", o vento da rua atrapalha, melhor nesse caso o corredor do prédio, no andar térreo (mais perto da rua na possibilidade de optarem por outra brincadeira), exatamente encostados na porta dos apartamentos, espalhados pelos primeiros lances de escadas, ou nos quintais e garagens das casas autoconstruídas do mutirão.

Os jovens (meninos e meninas) não suportam o enfado das "quatro paredes". Dessa maneira, as meninas fazem o mais rápido que podem os afazeres domésticos para depois irem para a rua, chamar aos berros a amiga do outro prédio, e juntas conversarem, irem em busca do "geladinho" no bloco da Segunda rua, onde poderão também encontrar o menino que paqueram, a colega da escola. Dali, podem ir às 16 h00 buscar o irmão menor de uma delas na creche, fazer companhia para comprar a mistura para hora do jantar, (recomendação da mãe que saiu pra trabalhar as 6:00 da manhã). Na repetitividade da vida diária, há ainda outras tantas coisas a fazer: ir ao posto de saúde marcar uma consulta para um membro da família, esperar lá fora o homem das frutas passar, receber para a vizinha o móvel novo, ir à casa lotérica pagar as contas, levar e/ou buscar os irmãos menores na escola, etc... À noite ainda resta ir à escola, ao curso de computação ou ajudar no jantar e voltar pra rua, encontrar alguém, combinar a próxima "balada", decidir por qual tonalidade de cor para mudar o visual dos cabelos, emprestar um CD, enquanto esperam o dia findar.

${ }_{163}$ Cigarro vendido de maneira avulsa. Um no máximo dois, vendidos à $R \$ 0,10$ ou $R \$ 0,15$ centavos de acordo com a marca do cigarro. 
Os meninos desocupados das prendas domésticas e de tudo que esteja relacionado a elas, ocupam-se em discutir as tramas dos filmes de ação, as estratégias dos jogos eletrônicos, as possibilidades de emprego ou de auferir algum rendimento, os modelos dos carros (objeto máximo de consumo), os acessórios para melhorar as motocicletas, as sensações desse ou daquele alucinógeno, as peripécias da última "balada", a peleja da última partida de futebol, a seqüência dos exercícios de musculação. 164

Às mulheres cabem as aspirações do móvel novo, as pequenas reformas para as habitações, as ofertas dos alimentos e demais produtos, os cuidados com os filhos e com a casa, a troca de receitas, a preocupação e reclamação com o senviço público de saúde, as indicações para os empregos domésticos, a espera por dias melhores.

A rua é vista para os mais conservadores como o locus da convivência masculina, lugar onde pode imperar a violência, o desmando, a embriaguez, o perigo de um modo geral. Por esse motivo, quanto menos as mulheres (crianças ou adultas) permanecerem na rua, melhor para a reputação e segurança delas ${ }^{165}$.

Em nossas observações, nos mais diferentes horários, dias e situações, lá estão os homens (crianças, jovens, adultos), "donos da rua": brincando, na calçada, nos bancos improvisados, nas áreas de estacionamento, e nos bares. Os bares são interessantes por possuírem inúmeras funções. É nos bares que os homens passam horas conversando e bebendo. Mas os bares também funcionam como uma espécie de classificados do Conjunto Habitacional Parque Continental. Lá estão afixados inúmeros anúncios: uma casa ou apartamento à venda, uma excursão a ser realizada, um festival de futebol, uma festa para comemorar o dia das crianças, um show musical no Conjunto ou em outro local do bairro, um bingo beneficente, o senviço de elaboração de currículos, a declaração de isenção do imposto de renda, etc. São também referências, pois é da frente dos bares que saem os homens para o jogo de futebol e os religiosos para a visita da igreja matriz.

É também nos bares ou na proximidade deles que acontecem as batidas policiais. Aliás, de quando em quando há "operações especiais" no Conjunto e a polícia militar monta sua "base" justamente em frente aos bares. Ali monitoram a entrada das pessoas, mormente daquelas que chegam em automóveis ou motocicletas. Questionam para onde vão, de onde vêm, checam os

164 Sem a possibilidade de freqüentar academias de ginástica, os garotos constroem sozinhos os equipamentos para a prática da musculação com cabos de aço, latas vazias de tinta e concreto. Treinam atrás dos prédios onde também deixam disponíveis os equipamentos para quem quiser usar. $\mathrm{E}$ assim alcançam rapidamente o ideal masculino de beleza.

165 Duas moradoras (amigas) em tom de desabafo contam que são mal vistas por freqüentarem os bares. Elas dizem não fazerem algazarra, não se meterem em confusão, simplesmente vão ao bar porque assim como os homens gostam da cerveja, do petisco, e da conversa. Para elas não existe problema, mas para muitos homens e mulheres, bar é lugar para ser freqüentado por homens assim como a rua e tudo que a envolve. 
documentos e pronto, o senviço está feito. Essas "operaçães" têm duração de três ou quatro dias. Sempre no mesmo local e (sic) no mesmo horário. Ressalte-se que há na área a prática do tráfico de entorpecentes, e alguns jovens fazem o controle da área vistoriando todas as ruas com aparelhos de rádio comunicação. A intenção é justamente antever a entrada de policiais na área do Conjunto e se necessário for "dispensar o flagrante". Em lugares de onde vêem e não são vistos, cumprem a função de monitorar a área contra a ação da polícia.

Ainda que por consenso da maioria, todos os bares sejam o locus da convivência e da sociabilidade masculina, muitas mulheres têm de lá ir: para comprar o gás de cozinha, os fósforos que acabaram ou outros produtos comprados de maneira avulsa e que suprem a necessidade imediata.

Em relação ao suprimento de necessidades imediatas, vejamos a importância dos comércios itinerantes que têm boa clientela no Conjunto. Em carros, penuas e caminhões pequenos, os também pequenos comerciantes são fundamentais para a labuta da vida nesse território cotidiano. Vendem frutas, legumes e verduras, produtos de limpeza, iogurtes, sorvetes, pães, doces, salgados. Trocam velharias (panelas, garrafas, baterias de automóveis) por maçãs do amor. Suas mercadorias são, sem exceção, de menor qualidade que aquelas compradas nas feiras livres, padarias e supermercados. E seus preços nem sempre são mais convidativos. Todos, sem exceção, elaboram peças de comunicação para atrair a freguesia. Conduzindo o veículo a uma velocidade inferior aos $30 \mathrm{~km} / \mathrm{hora}$, regulamentados para as ruas do empreendimento, os comerciantes anunciam seus produtos e os preços que praticam. A "qualidade" da freguesia é sempre explorada de alguma forma em anúncios ora gravados, ora repetidos e decorados. A título de exemplo: "Atenção distinta freguesia, acaba de chegar em sua rua o carro do padeiro. São duas bengalas doces por $R \$ 1,50$, duas bengalas salgadas por $R \$ 1,50$, bisnaguinha de creme, bisnaguinha de coco $R \$ 1,50$, broa de milho. Venha conferir nossa variedade de pães caseiros".

Em alguns casos, os comerciantes utilizam-se de músicas entre o anúncio e a pausa para atender a clientela. No carro da maçã do amor e no carro do churros, por exemplo, além do anúncio, músicas da Xıxa ajudam a chamar a atenção das crianças. No caminhão das verduras, além do anúncio, são os sambas com temas prosaicos de Zeca Pagodinho que têm a função de atrair as donas de casa.

"Passam" no Conjunto durante toda a semana, ou seja, os moradores estão sempre senvidos por um ou outro desses comerciantes. O caminhão das frutas, por exemplo, passa toda Segunda-Feira no período da tarde, o caminhão dos produtos de limpeza as Terças, Quintas e Sábados durante todo o período da manhã Além desses comerciantes que usam algum tipo de 
veículo para trabalhar, há também os que utilizam outros meios. Um rapaz vende mandioca e as carrega em um carrinho de mão (tipicamente utilizados nas atividades da construção civil), outro também usando um carrinho de mão vende verduras, outro vende mantas e redes carregando a mercadoria nos ombros e nas mãos. Seu corpo é seu veículo. Há também quem venda jogos de panelas, doces e queijos, panos de prato, calçados, lingerie, etc... e carregam suas mercadorias em imensas sacolas. Esses últimos, além de percorrerem as ruas, vendem também de porta em porta. Alguns usuários de drogas, ainda que não sejam necessariamente comerciantes, também fazem parte da provisão do Conjunto Habitacional. Ávidos pelo consumo dos entorpecentes, realizam pequenos furtos no comércio do bairro, fundamentalmente produtos de higiene pessoal fáceis de serem furtados por seu pequeno volume: cremes hidratantes, anti-sépticos bucais, colônias infantis, desodorantes antitranspirantes, shampoos, condicionadores, protetores solares. Vendem os produtos de porta em porta por valores convidativos: três frascos de creme hidratante por $\mathrm{R} \$ 10,00$, dois frascos de protetor solar com fator de proteção solar 20 por $\mathrm{R} \$$ $15,00^{166}$. Note-se que o dinheiro conseguido serve somente para o consumo imediato dos entorpecentes que são vendidos em pequenas porções e custam em média os mesmos valores que cobram pelos produtos roubados.

O aspecto mais importante dessa maneira de suprir as necessidades imediatas no Conjunto a nosso ver, diz respeito à comodidade com que são servidos os moradores. Isso porque é possível comprar as frutas e verduras enquanto a panela está no fogo, a lavadora de roupas em funcionamento. Não é preciso planejamento em relação ao horário, pois, enquanto se organiza a casa, as peças de comunicação anunciam a chegada do carro das frutas, do trocador de panelas, do vendedor de tapetes, do padeiro. Em poucos minutos está feita a compra, sem que seja necessária a saída de casa, a preocupação com a aparência para ir ao supermercado, o drama de não ter com quem deixar as crianças, ou pior para muitas mães: ter de levá-las ao local das compras.

Destacamos ainda a presença dos distribuidores do gás butano, sempre presentes no empreendimento, as maiores empresas do ramo cumprem uma escala semanal para atendêlo e distribuem brindes às donas de casa como colheres, pano de prato e copo. Quanto às menores, são contatadas via telefone.

O caminhão de entrega das Casas Bahia167 está freqüentemente por ali. A soma do desejo e/ou necessidade dos moradores de trocar os móveis e eletrodomésticos e as

\footnotetext{
${ }^{166} \mathrm{~A}$ prática de tão comum ganhou adeptos que fazem inclusive encomendas aos usuários.

167 Loja de móveis e eletrodomésticos voltada principalmente para a classe de menor renda, popular pelas "facilidades" de créditos concedidos aos consumidores e pela rapidez na entrega dos produtos e montagem dos mesmos. Em conversa com os moradores obtivemos a constatação de que "entre compra, entrega e montagem não
} 
"vantagens" da compra via crediário, garantem o sucesso de vendas da loja e por isso o caminhão de entregas está sempre na área do Conjunto Habitacional. Entregando nas casas do mutirão ou nos edifícios Cingapura novos conjuntos estofados, mesas, beliches, camas, colchões, armários de cozinha, lavadoras, refrigeradores, aparelhos televisores de 29", microcomputadores etc... Em qualquer dia da semana, também aos sábados, não raro aos domingos. Em horário comercial, mas notamos maior presença dos caminhões entregadores no período da manhã.

\subsection{A casa e seu movimento}

Em outro texto (Jesus, 2005), refletimos sobre a identidade com o espaço privado da casa como segue:

A casa expressa a individualidade de cada um, de maneira que ao construir, decorar e enfeitar uma nova moradia, as pessoas de acordo com suas diferentes experiências, recursos, aptidões (já que as habitações foram autoconstruídas) levam para dentro do seu território coisas, objetos, móveis, cores etc, nos quais está expressa sua identidade. Por esse motivo, supomos ser tão difícil padronizar as construções de um loteamento popular, a não ser quando o próprio poder público constrói as habitações (o que também não garante padronização). Quando da entrega das chaves, as casas são padronizadas - mesma cor, mesmo tamanho, mesmo modelo. Passados alguns anos, as reformas começam a ser feitas. Isso mostra que a identidade de cada um que é única e intransferível não é passível de homogeneidade e a diferença está materializada na maneira como as casas são ocupadas e/ou ampliadas.

Naquela ocasião, o alvo de nossa reflexão era um loteamento popular, em que os moradores contemplados pela Prefeitura Municipal com um lote construíram suas casas de acordo com suas habilidades e recursos, sem cumprir qualquer padrão técnico de construção. Nesse momento, o conjunto habitacional de nossa análise é homogêneo pelo menos no que respeita aos padrões construtivos ainda que, no nosso caso, a diferença visível se dê entre as casas assobradadas e os prédios de apartamento ${ }^{168}$. Nas casas, as ampliações ocorrem no recuo de fundo do lote, impossíveis de serem notadas pelos transeuntes, o que contribui para a impressão de homogeneidade. Quanto aos prédios de apartamento, não há qualquer possibilidade de ampliação.

demora mais que uma semana". Nas lojas concorrentes por vezes o preço é mais atrativo, no entanto a entrega e montagem de móveis pode demorar 20 dias, até um mês.

168 Os prédios de apartamento possuem dois projetos (seis edifícios construídos por empreiteira via Operaçães Interligadas e 21 edifícios também construídos por empreiteira via PROVER), mas as tipologias são parecidas inclusive no tamanho dos apartamentos e nas cores externas dos prédios. 
Daí nossa preocupação em depreender de que maneira ocorre a apropriação desse espaço pretensamente funcional e homogêneo.

Ao adentrar os edifícios, notamos a opção pela troca das portas dos apartamentos, não para descaracterizar o Projeto, como advertiu a equipe técnica da Prefeitura, quando das "proibições" de quaisquer tipos de reforma, mas para caracterizar o mínimo possível o morador do apartamento.

As reformas internas (única possível nos apartamentos) são a nosso ver, além da possibilidade de expressão da individualidade de cada um, uma manifestação (in) consciente da insatisfação como Projeto. Os motivos são os mais variados: o dormitório pequeno demais para muitos filhos, o lugar resenvado para a lavadora de roupa que somente comporta modelos mais modernos, o cheiro dos alimentos impregnado nas roupas em virtude da cozinha ser conjugada com a área de serviço, o varal diminuto para roupas das famílias numerosas.

Em relação às reformas das casas do mutirão, essas parecem estar mais próximas das realizações ambicionadas por seus moradores, pois além das reformas internas como pintura e revestimento, no recuo de fundo do lote são possíveis: fazer do dormitório uma suíte, construir oficina de costura, oficina de senviços gráficos, estúdio para ensaios e gravaçães, outro dormitório, uma edícula para abrigar o filho recém-casado, uma horta, uma boa casa para o cachorro, um salão de cabeleireiro, um ateliê de tatuagem, uma equipada área de serviço, um depósito, ou um simples, mas almejado quintal ${ }^{169}$. No recuo frontal, onde muitos optaram por fazer uma garagem para automóveis, encontramos quem tenha feito uma igreja evangélica.

É preciso salientar que a heterogeneidade ${ }^{170}$ de pessoas e das atividades que exercem reflete também nas reformas das habitações. Desse modo, assim como há quem tenha feito ampla reforma interna das casas e apartamentos, há também aqueles que jamais conseguiram quaisquer reformas nas habitações, permanecendo as mesmas sem nenhuma alteração, portanto, na mesma situação de quando foram entregues pela Prefeitura: paredes sem pintura, piso sem revestimento, mesma divisão interna dos cômodos, etc.

O que expusemos nos parágrafos anteriores tem acarretado uma curiosa dinâmica: há atualmente, por parte dos moradores dos prédios de apartamento, uma cobiça explícita no que diz respeito às casas do mutirão. Constituindo uma ambição imediata, pois as casas do mutirão além de serem maiores e permitirem maior individualidade (impossível no caso dos prédios), conferem também a possibilidade mínima de mudança Acompanhamos recentemente o caso

169 Todas essas possibilidades não estão de maneira nenhuma esgotadas. São simplesmente alguns exemplos do que observamos em trabalho de campo.

170 Uma das principais características da vida cotidiana assinalada por Agnes Heller. 
de uma moradora de um apartamento de dois dormitórios, casada, mãe de quatro filhas que vendeu 0 apartamento e comprou na mesma rua uma casa no mutirão $0^{171}$.

Esse caso ainda que isolado, expressa o anseio recorrente de muitos moradores, contudo, ocorre que as casas do mutirão são menos alienadas porque mais valorizadas e mais apropriadas e proporcionalmente estão menos suscetíveis à negociação, uma vez que se levarmos em conta todo o empreendimento, a proporção é de uma casa para cinco apartamentos. Também o valor praticado na venda das casas é mais que o dobro do valor praticado na venda dos apartamentos, o que pressupõe capacidade de planejamento financeiro para aqueles que queiram comprar uma casa no mutirão.

Em relação a casa (ponto fixo no espaço ${ }^{172}$ ) Agnes Heller nos diz:

O conhecido e o habitual são ao mesmo tempo o fundamento de nossas ações e uma necessidade nossa. Possuir um ponto fixo no espaço, do qual partir e ao qual voltar sempre, forma parte da vida cotidiana da média dos homens. Este ponto fixo é a casa, onde o conhecido e o habitual são necessários para criar além de um sentido de familiaridade, também o sentido da segurança. Somados a esses sentidos estão as relações afetivas e sólidas. (p.385)

Mais que isso, as casas e apartamentos no Conjunto têm outras funções que desenvolvem de outras formas o habitar. Na verdade, habitar no Conjunto implica outras atividades, e estas atividades não estão relacionadas somente à reprodução biológica, mas muitas vezes, também estão relacionadas com a reprodução das relações sociais. A casa é assim o lugar da intimidade, do descanso, da reprodução biológica da vida, mas não raro é também o lugar das ocupações em toda sua variedade: o artesanato, o comércio de guloseimas, o mecanicismo das máquinas ${ }^{173}$. É também o lugar do culto religioso, das benzeduras, do tráfico

171 Vale lembrar que recentemente os valores praticados nas vendas desses imóveis são aproximadamente $\mathrm{R} \$ 28$ mil para um apartamento de dois dormitórios com mínima reforma (pintura e revestimento) e $R \$ 60$ mil para uma casa do mutirão com pelo menos as mesmas benfeitorias. Para fins de estimativas a cotação do dólar em Agosto de 2008 foi de $\mathrm{R} \$ 1,61$.

172 Examinada pela autora como categoria de representação e experiência interior do espaço. As outras categorias são: direita e esquerda, em cima e embaixo, perto e longe e o limite; revisadas mais adiante.

173 Uma moradora de apartamento costureira especializada em mochilas, bolsas, frasqueiras e similares tem no lugar da sala uma pequena oficina de costura com três máquinas e outros equipamentos necessários ao ofício. Quando questionada sobre a possibilidade de trabalhar em uma empresa, ela afirma ser melhor opção trabalhar em casa, uma vez que não tem patrão, nem horário. Note-se que ao ser contratada para uma grande encomenda, por exemplo, 300 bolsas (que já vêm cortadas necessitando apenas do arremate) e um prazo estipulado para terminar 0 trabalho, ela passa dias inteiros sentada à máquina de costura, levantando para ir ao banheiro e alimentar-se, contando com a ajuda da filha adolescente para as tarefas domésticas. Vejamos que seu trabalho é tão alienante quanto o trabalho da fábrica. Na verdade seu trabalho não deixa de ser fabril por ser executado em sua sala. O que vemos nesse caso é a contradição entre forma e função. 
de entorpecentes, das reuniões para tratar de diversos assuntos: dos produtos da Avon ${ }^{174}$ aos problemas do condomínio.

Quanto à forma interna das casas e apartamentos, porque iguais do ponto de vista arquitetônico, têm a mesma divisão dos cômodos, acomodam da mesma maneira o mobiliário. Não há como nas favelas e nas diminutas casas de aluguel sobreposição de função dos cômodos. Quando ocorre a sobreposição de função está restrita ao espaço da sala, lugar por excelência da sociabilidade, onde reina o aparelho televisor sempre ocupando o centro da sala, sempre ligado como que "recepcionando" aquele que chega para cortar ou trançar o cabelo, ou o cliente em busca da encomenda.

Em nossas visitas às casas e apartamentos do Conjunto, dois casos merecem menção: uma moradora de apartamento de um dormitório reduziu significativamente o espaço da sala, para dar lugar a um novo dormitório para os filhos. Em sua nova sala, há somente um móvel que acomoda a portentosa televisão de plasma de 29" e duas poltronas dispostas a menos de um metro do aparelho. Em outro caso ouvimos: "Na minha casa não tem televisão na sala, porque a visita vem na sua casa, parece que está visitando a televisão e não você. A pessoa fica hipnotizada com a TV, vem pra conversar, não conversa, porque tem que prestar atenção na TV, ou pior, conversa com você, olhando pra televisão. Não tenho televisão na sala, minha televisão é no quarto. Só no quarto". "Só" no quarto, diz respeito ao fato de a imensa maioria dos moradores possuírem no mínimo dois aparelhos televisores em casa: um para a sala, e outro para o quarto. Todavia, há muitos casos de moradores que possuem um número maior de aparelhos televisores. Os dois casos referidos por nós, são pólos opostos e extremos da relação dos moradores com a televisão. No primeiro caso, em virtude da construção do quarto dos filhos a moradora não tem mais uma sala, quem a tem é a televisão. Se tivesse usado todo o espaço para o quarto, a televisão poderia estar no quarto dos filhos, e a casa ficaria sem sala. Desse modo, melhor fazer uma sala só para a televisão. Literalmente.

No outro caso, nossa entrevistada crítica em relação à atenção dispensada à televisão pelas visitas, leva para longe o "inimigo" com o qual não tem forças para lutar. Logo, se a televisão não está na sala, não há com "quem" competir atenção, mesmo que paradoxalmente as visitas tenham ido visitar uma pessoa e não uma televisão como ela reflete analogicamente. Não obstante, o embate entre anfitriã e televisão não ocorreria caso a televisão permanecesse

174 Poderosa indústria de cosméticos que tem como preceito principal a venda de seus produtos via catálogo por revendedoras de porta em porta, não contando com o espaço físico de lojas. Além dos produtos cosméticos (sua maior característica) há também a venda de outras mercadorias como bijuterias, CDs, livros de auto-ajuda, acessórios de cozinha, lingerie, calçados, etc. "A gente conversa, a gente se entende", era uma de suas peças publicitárias referindo-se às revendedoras e às clientes e ao diálogo íntimo fundamental nesse tipo de transação. 
desligada, mas mesmo que a moradora em questão não seja fervorosa adepta do aparelho, a televisão permanece ligada, está sempre ligada pelos mais variados motivos: acalma o bebê, distrai as crianças, faz companhia enquanto as donas de casa estão sozinhas, serve para elas acompanharem o noticiário de longe quando estão cozinhando, "avisam" quando a novela começa, enfim... Partindo dessa reflexão, arriscamos: a televisão é quase um ente da família.

A oposição entre casa versus rua de que nos informa Roberto DaMatta (1991) encontra em nosso território cotidiano outras expressões. Na referida obra, a rua indica fundamentalmente o mundo, com os imprevistos e as paixões, enquanto a casa se refere a uma realidade controlada, em que cada coisa ocupa o seu lugar certo. Na rua encontramos novidade, movimento, ação. $\mathrm{Na}$ casa reinam ordem, calma, afeto. Em casa, as relações se regem normalmente pela hierarquia do sexo e da idade, ao passo que na rua esse relacionamento se dilui e se anula. A rua é o local público, dirigido pelo "Governo" ou pelo "destino", essas forças impessoais que nos escapam do domínio, onde se acham os personagens perigosos, malandros e marginais. Tudo que diz respeito a cuidados e recuperações do corpo e que implica descanso e renovação se associa a casa.

A casa é o lugar da família, à qual tem acesso os parentes e amigos e, portanto, todos sabem quem são, do que gostam e o que podem fazer; enquanto que a rua é lugar dos estranhos e por isso mesmo, lugar de tensões e conflitos, uma vez que não se conhece e não se tem afinidades com quem está na rua. Mesmo que as ruas do território cotidiano do Conjunto Habitacional não estejam livres de conflitos e tensões, o que se vê é uma significativa intimidade com a rua, pois na rua estão também família e conhecidos, antigas referências, uma vez que em sua quase totalidade, as famílias vieram dos mesmos lugares, e quando não são vizinhos diretos morando no mesmo andar, no mesmo prédio, na mesma vila de casas a distância é somente aquela que separa uma e outra rua do Conjunto.

Com as alienações dos imóveis, a intimidade com a rua ou com a totalidade do Conjunto tende a aumentar, pois as transações dificilmente ultrapassam as relações interpessoais dos moradores ${ }^{175}$. Significa dizer que, os apartamentos ou casas são vendidos na maioria dos casos para parentes, amigos ou pessoas próximas contribuindo dessa forma para maior solidez às redes sociais.

175 Não há agentes imobiliários como intermediários no processo de compra e venda dos imóveis do Conjunto Habitacional. A divulgação é feita "boca a boca" dentro do próprio Conjunto, e a compra e venda são resolvidas entre os próprios interessados, que no máximo comunicam a Prefeitura da transação como intenção de transferir oficialmente a documentação referente ao imóvel. Eventualmente aparecem no Conjunto interessados "de fora" em comprar um imóvel. 
A rua é também uma extensão da casa nesse teritório cotidiano. Comportamentos e atividades que normalmente ocorrem no espaço privado da casa transbordam-na por falta de espaço, por falta de privacidade, ou por falta de ambos ${ }^{176}$. Na rua e nos seus entremeios, os assuntos mais íntimos são discutidos, planos são tramados, bebidas são preparadas, alimentos são compartilhados, sobrancelhas são modeladas, unhas são cortadas, tapetes e cadeiras são lavados, bebês são amamentados, drogas são usadas, o sexo é praticado.

Nesse caso, difícil delimitar com precisão a relação com a casa e a rua, pois aparecem sobrepostas na trama da vida cotidiana.

Para nós, a funcionalidade do habitat não é suficiente para regular toda a vida, pois ainda que morar em apartamentos ou casas propositalmente funcionais signifique organizar certos aspectos da vida de uma determinada maneira só, vimos que outros tantos aspectos do habitar encontram outras fendas para realizar-se.

Sobre esse aspecto Amélia Damiani (1999) destaca "Se o cotidiano é o lugar do programado, das necessidades fixadas, dos tempos administrados, sob o peso do que vem do mundo, ele também é, nessa mesma177 medida, o lugar da vulnerabilidade de toda a programação". (p. 169), ou como indaga Almeida (1997) "Se há repetição no cotidiano, onde haverá um flanco, um lugar para modificações, para a distinção que gostaríamos de alcançar, pela via de nossa análise?' (p.99).

O que nos remete à contribuição de Michel de Certeau proponente de uma teoria das práticas cotidianas. Para ele, a antidisciplina ${ }^{178}$ dos consumidores é central para seus estudos. Esse termo aparece em sua obra como "resistência" ao desenvolvimento do que ele chama de "produção sócio-cultural". É então através dela que o homem ordinário encontra escapatórias e astúcias para sobre (viver). № entanto, esse termo só faz sentido se analisado em relação às estruturas da sociedade tidas como disciplinadoras (igreja, família, mídia, escola), por estas serem responsáveis em alguma medida pela formação de determinados comportamentos e percepção do mundo dos homens ordinários. Seu intuito era de chamar atenção para as capacidades criativas, inventivas desse homem, "habitante" por excelência da vida cotidiana.

Para esse autor "o homem ordinário faz bricolagem com e na economia cultural dominantes, usando inúmeras e infinitesimais metamorfoses da lei, segundo seus próprios interesses e suas regras". (p.40).

É na própria vida cotidiana que estão todas as possibilidades: de alienação e de

176 Ver também Silva $(1998,2006)$.

177 Grifo nosso.

1780 autor nos informa que o termo antidisciplina é eco da obra de Michel Foucault (1994, p.17). 
subversão.

\subsection{Espaço cotidiano - o lazer praticado no Conjunto.}

Para empreender a análise do lazer praticado no território cotidiano, foco de nossa análise, é necessário assinalar que esta dimensão da vida cotidiana ocorre quase sempre nos limites do Conjunto Habitacional.

Por esse motivo, contamos com a contribuição de Agnes Heller no que diz respeito ao espaço cotidiano. Sua primeira premissa relativa a esse espaço é de que este é antropocêntrico, pois, em seu centro está sempre um homem. E sua articulação está sempre fixada pela vida cotidiana, onde a experiência interior espacial e a representação do espaço estão indissoluvelmente inter-relacionados. A partir disso, examina as categorias do que ela denomina representação e experiência interior do espaço. Essas categorias são: direita e esquerda, em cima e embaixo, perto e longe, o limite, o ponto fixo no espaço (a casa) ${ }^{179180}$. Examinemos a categoria limite.

Para ela o limite é a fronteira do espaço em que se movem nossas ações. Para aquele que no curso de sua vida não saiu nunca de sua aldeia, o limite é a aldeia. Num duplo sentido: por um lado, suas ações só estão motivadas por experiências efetuadas dentro desse espaço determinado, por outro, o raio de ação de seus atos não supera os limites desse espaço. №

179 Grifos da autora.

180 Direita e esquerda - São modos intuitivos de viver o espaço que servem para orientar-se nele. Para a autora no espaço não existe objetivamente nem "direita" nem "esquerda", nos orientamos com base nessas categorias para que seja possível ao homem se relacionar com o espaço. Em cima e embaixo - São também categorias da representação ou experiência interior do espaço que servem para a orientação. o entanto, essas categorias são mais "objetivas" do que as categorias "direita" e "esquerda". O raciocínio da autora é de que o sistema de referência natural da vida e do pensamento cotidiano é a terra; e quando nos referimos às categorias "em cima" e "embaixo" estamos nos referindo às coisas da terra. E lança um exemplo para justificar a importância da objetivação de "em cima" e "embaixo" em nossa representação do espaço. "Quando se olha em um espelho, a direita e a esquerda aparecem invertida sem que se tenha a sensação de um 'mundo invertido'. Mas se alguém se vê com a cabeça para baixo, sente aquele espaço como 'contra natureza'". (op. cit, p. 383). Perto e longe - Para a autora a distinção entre perto e longe serve antes de tudo para designar o campo de ação de nossos atos: é mais fácil atuar sobre o que está perto que sobre o que está longe. Muito longe é uma coisa que está fora do raio de ação de nossos atos. Perto e longe indicam também igualdade ou diferença de usos. Assim são ou estão perto aqueles lugares, regiões, etc, onde o comportamento é similar ao nosso, são ou estão distantes aqueles lugares nos quais o comportamento é distinto ao nosso. (p.383). Desse modo é fácil compreender o não acesso à lugares e instituições muitas vezes próximos espacialmente, mas que em virtude das diferenças de uso, de público e de comportamento desse público tornam-se distante. É o caso de shopping centers, bibliotecas, condomínios, museus, praias, etc. Quantas vezes não comentamos "Sempre passo por aqui, mas nunca entrei!!" Também o sucesso das relações interpessoais é determinado em grande parte por proximidade ou distância. A proximidade é quase um pressuposto para o estabelecimento de uma relação entre as pessoas. E se por exigência da vida acontece de um grande amigo mudar-se para outra região, outro estado, outro país, os contatos vão diminuindo, até passarmos longos anos sem ver, ou no limite nunca mais vemos aquele amigo. O mesmo raciocínio vale para as relações de parentesco: consideramos mais próximos os amigos sem consangüinidade que está perto, do que o irmão consangüíneo que está longe. 
primeiro sentido o limite é muito elástico. Durante longos períodos históricos, o saber cotidiano da maioria dos homens se produziu dentro de limites relativamente restringidos. Na atualidade, os limites concernem a todo o globo terrestre, o espaço nesse sentido se estendeu muito. ${ }^{181}$

Por extenso que possa ser o espaço, o raio de ação do homem que vive sua vida cotidiana permanece sempre dentro de limites determinados. Somente a elevação à esfera das objetivações genéricas para si permite por princípio superar todo limite terrestre $^{182}$. $(1994,384)$.

Mesmo reconhecendo a extensão do mundo, Agnes Heller não ignora que o homem cotidiano vive nos limites do seu espaço. Esses limites são aqueles do entomo imediato e de suas relações de vizinhança. A título de exemplo, lançamos duas simples questões: Quantos paulistanos moradores de áreas periféricas, sequer conhecem a Avenida Paulista ou mesmo a área central da cidade? Quantos paulistanos nunca foram à área litorânea do Estado, mesmo aquela não distante da capital mais que $100 \mathrm{~km}$ ? As respostas a essas perguntas corroboram o raciocínio da autora e com o qual concordamos de que "o raio de ação de seus atos não supera os limites desse espaço".

No âmbito dessa investigação, é no limite do espaço do Conjunto Habitacional que se realiza o lazer, quando mais longe o lazer é realizado no seu entorno. Raras são as exceções de lazeres realizados mais distantes dali. Esses quando o são, são pensados, elaborados, combinados dentro do espaço do Conjunto, como por exemplo, as "baladas", visitas às igrejas, jogos de futebol. Não raro, em datas comemorativas como Camaval ou Natal, há no Conjunto a opção em não sair de lá para ver, por exemplo, o show de uma banda de forró ou de um grupo de samba. Esses são contratados para tocar nos bares do Conjunto situados ente os edifícios ou nas vilas de casas do mutirão.

Nesse sentido, a identidade com o Conjunto incita a prática do lazer ali mesmo. Podemos indagar se não são também suas estreitas economias que não permitem aos moradores praticar o lazer em outros locais da cidade. No entanto, atividades culturais gratuitas promovidas pela Prefeitura Municipal, como shows musicais, concertos, caminhadas, apresentações de teatro, mesmo quando ocorrem próximas dali, como por exemplo, no Parque Vila Lobos, ou em alguma praça do distrito do Jaguaré, não têm grande aceitação pelos

181 Essa discussão nos remete às metáforas empregadas pelos estudiosos da modernidade, como por exemplo, "aldeia global" que refere-se a extensão do mundo de que fala Agnes Heller, e o "fim do espaço" que refere-se à não determinação do espaço físico em detrimento da velocidade do tempo para a ocorrência de muitos eventos. A esse respeito ver Harvey, David. A condição pós-moderna. São Paulo: Editora Loyola, 1992 e Virillo, Paul. 0 espaço crítico e as perspectivas do tempo real. (Tradução de Paulo Roberto Pires) - Rio de Janeiro: Editora 34, 1993.

182 Grifos de autora. 
moradores do Conjunto Habitacional Parque Continental, talvez porque as programaçães não façam parte do seu repertório cultural e também porque elas não aconteçam no Conjunto.

Destacamos que o lazer como dimensão da vida cotidiana não pode ser analisado no âmbito dessa pesquisa simplesmente como folga e tempo livre do trabalho. Isso porque, entendemos lazer como folga, férias, mas também o entendemos como desocupação. Pois, na vida cotidiana nem sempre há a separação entre trabalho e lazer. Por vezes, o lazer não ocorre externamente a casa/trabalho' ${ }^{183}$, ao contrário, aparece nesses próprios ambientes, não havendo nesse caso dissociação entre uma e outra atividade. O lazer como categoria explicativa não é suficiente para abarcar todas as atividades observadas no interior do Conjunto.

Encontramos casos de garotas adolescentes que recebem dos pais alguma remuneração para cuidar dos irmãos menores ${ }^{184}$. Remuneração que seria paga a outra pessoa ou a alguma instituição de ensino infantil se não houvesse a colaboração da filha. Enquanto organizam incansavelmente suas casas e cuidam das crianças, escutam e cantam em volumes absurdos a letra erótica do forró, o romantismo do pagode, as conhecidas, mas incompreensíveis letras da black music ${ }^{185}$, os protestos do rap nacional.

Um morador por nós entrevistado, residente no Conjunto desde a sua implantação, trabalhador em uma peixaria do bairro, preparou recentemente o I Festival de Futebol do Mutirão ${ }^{186}$. Para a execução do referido festival, se ocupou intensamente na organização dos times, divulgação do evento no Jaguaré e bairros adjacentes ${ }^{187}$, buscou apoio de patrocinadores, acompanhou de perto a confecção de faixas, folders, troféus, elaborou a tabelas de jogos. Enfim, cuidou de todos os pormenores que o festival demandou. Quando perguntado sobre essa atividade, o morador referiu-se ao festival como um lazer, uma atividade com a qual se ocupa em suas horas vagas. Vejamos que as horas vagas (tempo livre) a que se refere, dizem respeito ao período de descanso do trabalho (tempo obrigatório) com a peixaria e que são preenchidas com o "trabalho" de idealizar e realizar o festival de futebol 188 .

Vejamos que nos dois exemplos não há dissociação entre trabalho e lazer. As duas categorias se misturam, coexistem, o que remetenos à apreciação de Agnes Heller com a categoria trabalho. Vejamos:

183 Assim como o "trabalho" muitas vezes acontece no próprio ambiente doméstico.

${ }^{184}$ Quando questionamos sobre as creches, obtivemos como resposta que algumas mães não conseguem as vagas para os filhos, outras não confiam os cuidados dos filhos a essas instituições.

185 Música negra norte-americana.

186 Mutirão entendido nesse caso como a totalidade do empreendimento.

1870 festival ocorrido em 12/10/2007 contou com a participação de 14 equipes dos bairros do Jaguaré, Rio Pequeno, Jardim Bonfiglioli, Jardim Helena Maria e Rochdale (os dois últimos bairros do município de Osasco).

${ }_{188}$ Cada equipe participante contribuiu com a quantia de $R \$ 50,00$ para arcar com as despesas dos jogos, como por exemplo, a contratação de árbitros e gandulas para as partidas. A quantia restante foi dividida entre os organizadores do festival. 
A preocupação de Agnes Heller com essa categoria encontra subsídios nas análises de Marx, especificamente no que se refere à diferenciação entre dois de seus aspectos: como execução de um trabalho que é parte orgânica da vida cotidiana e como atividade de trabalho, que é uma objetivação diretamente genérica. Para essas dimensões os termos sugeridos por Marx e estudados por Heller são labour e work respectivamente.

Essa autora destaca que a análise do processo de trabalho em Marx não constitui novidade, para ela a inovação está em sua análise das circunstâncias concretas em que se desenvolve o processo de trabalho concreto, do modo em que este se realiza como trabalho para a sociedade em seu conjunto (work) e do que significa trabalho para o trabalhador (labour), em suas palavras, o particular.

Work é o aspecto do trabalho considerado como atividade criadora, forma de socialização, partindo dessa perspectiva o trabalho produz valores de uso.

(...) O produto do trabalho deve sempre satisfazer uma necessidade social e encarnar o tempo de trabalho socialmente necessário para fabricá-lo. Se um produto não satisfaz nenhuma necessidade social ou é fabricado em um tempo de trabalho superior ao socialmente necessário, não se pode falar de work, mas somente de labour. $(\text { p.120) })^{189}$

Da citação acima inferimos claramente a noção "contrária" de work, labour é desse modo, o trabalho alienado. Na vida cotidiana, a reprodução dos indivíduos é necessária e por isso "a maioria dos homens devem efetuar um trabalho", "nesse sentido o trabalho é uma atividade cotidiana".

Todavia, Agnes Heller não destaca ou privilegia uma dimensão em detrimento da outra:

O fato de que o trabalho seja ao mesmo tempo uma ocupação cotidiana e uma atividade imediatamente genérica que supera a cotidianidade deriva-se da especificidade ontológica do trabalho e não tem nenhuma relação necessária com sua alienação. Também outras atividades cotidianas podem ser ou não efetivamente alienadas. (...) (p.123).

Mais adiante Heller corrobora esse raciocínio:

Estes dois momentos pertencem a um único processo que pode ser observado seja desde o ponto de vista do desenvolvimento conjunto da humanidade, ou seja, desde o ponto de vista do particular que trabalha. (p.126)

E se importa em acrescentar que se na sociedade todo trabalho é ao mesmo tempo work e labour, excepcionalmente pode haver também atividades em que falte um dos dois

189 Grifos da autora. 
momentos.

Voltemos novamente nossa atenção para o lazer.

O lazer é também propositalmente programado, anunciado mesmo nos domínios do Conjunto. Um carro de som passa pelo empreendimento divulgando a noite de festa do point dos jovens e adolescentes nas proximidades dali. Para assegurar casa cheia, além da divulgação da casa noturna e de suas atrações ${ }^{190}$, são distribuídos convites cortesia para as meninas. Para os meninos há promoções, como por exemplo, o sorteio de um aparelho MP3, possível a partir da aquisição do ingresso pelo preço módico de $R \$ 3,00$. Algumas meninas esperam o carro do Point ${ }^{191}$ passar para conseguirem os convites cortesia, pois essa talvez seja a única maneira de participarem da "balada".

Na vida cotidiana regida pelo cotidiano (modo de vida específico da contemporaneidade capitalista), o consumo é incomensuravelmente programado, em todas as suas esferas, em todas as suas possibilidades. O consumo de hábitos, comportamentos, alimentos, gostos, produtos, móveis, imóveis. Espantosamente, a eficiência e a eficácia da mídia, da propaganda, do discurso oficial, da ideologia dominante, fazem seus seguidores, seus fiéis consumidores. Pouco questionadores de suas reais necessidades, mas obedientes quanto às palavras de ordem diretas e muitas vezes, indiretas que incitam ao consumo. Não resta escolha ou opção entre consumir e não consumir, essas quando existem restringem-se ao ato de consumir, face às milhares ofertas de produtos e coisas materiais ou não, pois há ofertas também de felicidade, prazer, conforto, modos de vida.

Sobre essa reflexão, autores como (Martins, 2002) se pronunciaram sobre a "nova pobreza" ${ }^{192}$. As pessoas se não têm casa, ou não têm a propriedade da casa, não abrem mão das parafernálias eletrônicas, deixam também de conduzir automóveis velhos, pois atualmente, é possível adquirir um carro novo ou seminovo sem nenhum recurso financeiro imediato. $E$ as peças publicitárias, através de todos os meios de comunicação, cercam desse modo seus potenciais consumidores. Cada vez mais adeptos recorrem aos créditos individuais para comprarem desde os alimentos perecíveis aos automóveis.

190 São exemplos do repertório da casa noturna o forró, o funk, a black music e o pagode, e timidamente a música eletrônica. Esses segmentos musicais são distribuídos pelos dias da semana, de Quinta-Feira a Domingo, como fazem outras casas noturnas na cidade.

191 Nome da casa noturna em questão.

192 "O pobre ostensivo, mal vestido ou esfarrapado, estereotipado, que havia há algumas décadas foi substituído pelo pobre para o qual a aparência e 0 aparente e, portanto, o disfarce, tornou-se essencial. Os pobres descobriram uma característica fundante da sociedade contemporânea e da Modernidade, a da realidade social como máscara, a incorporaram e por meio dela realizam a sua plena e impotente integração social". (p.37). O autor encontra subsídios para sua análise em dados que demonstram o aumento significativo de lavadoras de roupas, aparelhos televisores, ligações telefônicas, etc em áreas de favelas. Para Guy Debord (1997), pensador da Sociedade do espetáculo "o que ébomaparece, e o que aparece ébom". 
Novamente recorremos a Henri Lefebvre (1991):

Não é o consumidor nem tampouco o objeto consumido que têm importância nesse mercado de imagens, é a representação do consumidor e do ato de consumir, transformado em arte de consumir'193. Ao longo desse processo de substituição e de deslocamento ideológicos, conseguiu-se afastar e até apagar a consciência da alienação, acrescentando-se alienações novas às antigas. (p.62)

Importa dizer ainda que, quanto mais o consumo é programado, mais são engessadas as possibilidades de criação dos moradores. No entanto, há sempre uma lacuna, e as pessoas ainda que alienadas ao consumo programado encontram algum "desvio" nos conteúdos, formas e usos.

Vejamos três exemplos: na falta de um palco adequado para a banda de forró se apresentar num dos bares do Conjunto, a mesa de sinuca ganha outro uso, e é imediatamente transformada em palco, onde os músicos tocam e as bailarinas dançam exibindo sua sensualidade.

Para o funcionamento de um bar, ou qualquer outro estabelecimento comercial, existe a necessidade de um "espaço", onde se edifique o estabelecimento para abrigar mercadorias e pessoas. Na impossibilidade de um pedaço de chão, um automóvel velho impossibilitado de sua função maior que é circular, por sua inércia delimita o espaço necessário para o bar. Expliquemos: uma velha perua Kombi parada nos fundos de um dos edifícios, à rua Peixe-Boi (que dá acesso ao Conjunto), esperou por muito tempo recursos financeiros de seus proprietários para ser consertada. O recurso não veio, a falta de uso enferrujou sua lataria e a perua passou da categoria de "ferro velho" para "bar novo". Dentro dela funciona um modesto bar, que somente comercializa bebidas e eventualmente espetos de churrasco. Uma lona presa ao seu teto e a um poste próximo da área em que está situada protege seus freqüentadores das intempéries e caixotes fazem às vezes de cadeiras.

As crianças de 7 a 10 vão acompanhadas de suas mães, ou com as vizinhas à escola por outro caminho que não as ruas oficiais do bairro. Uma brecha foi aberta no muro que separa o Conjunto do grande terreno baldio ao lado. Assim, percorre-se um tempo consideravelmente menor do que se a opção fosse as ruas e avenidas do bairro. Também por essa brecha, os homens têm acesso a um descampado onde praticam futebol. (Ver Imagem 1). Esses são exemplos práticos da antidisciplina de que nos fala Michel de Certeau.

193 Grifo nosso. 
Vemos através desses exemplos que a (re) significação de coisas, objetos e lugares, dá conteúdo à vida cotidiana, mesmo que esta esteja absorta em normas e condutas pretensamente homogêneas, idealizadas pelos promotores do empreendimento e calcadas no modo burguês de apropriar-se do espaço.

Para entendermos o lazer de nosso território cotidiano, consideramos de fundamental importância a relação de seus rendimentos que em muito determina seus gostos culturais. E, por conseguinte, consideramos também esses gostos, que no âmbito dessa pesquisa e nesse momento do mercado fonográfico, encontra maior expressão no gênero musical do forró.

Tal expressão relaciona-se certamente com as estratégias do mercado fonográfico, mas também, com a identidade dos migrantes nordestinos na cidade de São Paulo. Esses migrantes (re) territorializaram-se ${ }^{194}$ na metrópole, citemos a título de exemplo, 0 Largo da Batata no distrito de Pinheiros e o Largo Treze de Maio, no distrito de Santo Amaro, onde há reproduções da culinária, da música, do comportamento, enfim dos hábitos culturais nordestinos.

Sobre a identidade sociocultural de migrantes nordestinos, Expedito Silva escreve:

Ao chegar a uma metrópole do Sudeste, o nordestino procura inicialmente manter um estilo individual próprio. As necessidades geradas na luta pela sobrevivência levam-no, entretanto, a aglutinar-se em grupos sociais com características semelhantes, formando associações em busca de soluções para seus novos problemas. Naturalmente, assim como ocorre com uma família inteira que se transfere do campo para a cidade, apesar de procurar resguardar sua identidade nesses nichos, os choques culturais são freqüentes. Nesse processo de contato são gerados novos comportamentos, novas atitudes e posturas. E as influências do meio externo incidem tanto no cotidiano familiar, como no modo de educar os filhos, quanto no desenvolvimento de desejos tipicamente urbanos ${ }^{195}$. $(2003$, p.15)

Todavia, mesmo sujeito às influências do meio externo alguns comportamentos e costumes persistem, permanecem. Para exemplificar, consideremos justamente o forró, gênero musical que sempre representou uma importante referência no cotidiano de migrantes nordestinos (tanto o forró tradicional para as mais antigas gerações, como o forró eletrônico versão moderna do gênero que ganha cada vez mais adeptos na cidade de São Paulo, principalmente nas áreas periféricas e inclusive em nosso recorte territorial) e que conta com emissoras de rádio, casas noturnas e lojas específicas. É a afirmação da migração nordestina na metrópole em todas as suas dimensões.

194 Nos termos propostos por Rogério Haesbaert (2002, 2004).

195 Referindo-se aos anseios do consumo de eletroeletrônicos, eletrodomésticos, automóveis etc. 
No microcosmo do Conjunto habitacional, a música (fundamentalmente o pagode, o funk e a black music) e em uma escala surpreendente o forró, impressionam pela maneira como comparece na vida cotidiana dos moradores. Silva (op. cit.) considera que

a princípio, a indústria cultural não pretende uniformizar os anseios de consumo de toda a população, e talvez por isso seus produtos sejam distribuídos por classes. $\mathrm{O}$ consumo de um aparelho de som ultramoderno e o lançamento dos primeiros CDs na década de 1980 foram destinados a um público de maior poder aquisitivo; apenas posteriormente, visando à massificação total do produto, se dirigiram para as demais classes sociais.(p.29)

Essa evolução tecnológica também populaniza outros segmentos. № entanto, atualmente toda evolução prima pelo legado da imagem, não em detrimento do som, mas complementando-o: vide os microcomputadores, aparelhos de telefonia celular, máquinas fotográficas digitais, câmeras digitais, filmadoras, etc. Todos esses aparelhos combinam imagem e som E sua popularização permite a apropriação das classes populares pelo domínio do "know how" mínimo necessário para a produção de CDs e Dvds, por exemplo, que são copiados e daí divulgados. A título de exemplo, há um certo cantor baiano que alguns moradores do Conjunto se orgulham em dizer que "ninguém tem", uma vez que um morador que regressou a poucos meses da Bahia (onde esteve para visitar seus parentes), trouxe a novidade em "primeira mão" para São Paulo. A "novidade", porém, já chegou compilada em CD (cópias foram providenciadas em um computador pessoal) e a divulgação foi feita "boca a boca", melhor dizendo de "ouvido a ouvido".

Para Hermano Viana ${ }^{196}$

O que há de novidade é que talvez não seja mais necessário passar pelo centro para a cultura da periferia se transformar em cultura de massa. Além disso: nem os Racionais nem a banda Calypso precisam mais do velho centro (com suas tradicionais instâncias críticas de consagração, sejam elas universitárias ou industriais para se tornarem o centro de novos vastos mundos). (Folha de São Paulo, 14/12/2006).

Esse raciocínio é condizente com a produção, circulação e divulgação independentes de CDs e DVDs de bandas nordestinas de forró e similares, comercializados por ambulantes pelas ruas de comércio popular da cidade: 12 de Outubro, 25 de Março, Largo 13 de Maio, Largo da Batata e outras.

Sobre a "pirataria" (processo que envolve as dinâmicas anunciadas no parágrafo anterior), Mano Brown (líder do grupo de rap Racionais Mc's) se pronuncia:

196 Hermano Vianna, antropólogo e roteirista do programa Central da Periferia exibido pela TV Globo. 
Conheço os irmãos que estão na rua vendendo: "Ô Brown, assina aí!" Eu falo: pirata eu não assino, irmão. Mas é sobrevivência. Eu entendo. Cara, na verdade quem fica rico é o chinês. Mas, é o ganha pão do irmão também. Então como eu não sou polícia e também não vou andar com polícia prendendo pirateiro que não é a minha, eu uso aquele slogan: vocês são a minha rádio, tocam o dia inteiro a minha música no centro da cidade e divulga aí e me ajuda $O$ que eu não ganho em venda, eu ganho em outras coisas que eles me dão, a pirataria me dá notoriedade, põe a minha música na rua ${ }^{197}$.

Na prática, o que ocorre é a competição desenfreada e "despercebida" dos gêneros musicais ou mesmo de músicas do mesmo gênero musical. Nos edifícios e nas casas, os moradores ouvem ao mesmo tempo e no mesmo alto volume diversas músicas. À poluição sonora dos edifícios, somam-se as músicas ouvidas dentro dos carros estacionados e as dos veículos que comercializam produtos no empreendimento, também a gritaria das crianças e suas mães que chamam para o almoço ou o banho esquecidos, também o ruído do motor das motos e carros.

Investiguemos nesse momento o lazer visto sob outro ponto de vista: aquele da promoção do poder público municipal.

Referimos-nos ao Projeto idealizado pela Prefeitura Municipal conhecido como Rua de Lazer, que consiste basicamente no fechamento de uma determinada rua da cidade pela CET (Companhia de Engenharia e Tráfego) aos finais de semana e no empréstimo de materiais e equipamentos esportivos para os moradores da rua em questão. Para sua efetivação é necessário haver a anuência de no mínimo 60\% dos moradores da rua em documento reconhecido e lavrado em cartório que deve ser posteriormente encaminhado à Subprefeitura da qual o bairro esteja sob jurisdição.

No Conjunto Habitacional Parque Continental, a Rua de Lazer chegou ao conhecimento dos moradores através de uma assessora de um vereador.

É o pronunciamento de Roberta, uma moradora envolvida com o projeto durante o período de sua execução que nos informa como ele aconteceu:

(...) a gente tinha então junto à Rua de Lazer o apoio, de idéias, a fala de uma assessora de um determinado político. Ela que chegou pra gente e falou que nós tínhamos direito. Então essa pessoa, além de ser assessora, além de ter os interesses dela, ela tinha também muito boa vontade, ela era uma pessoa humana, vinha, conversava, a gente fazia os eventos, ela participava efetivamente. Assim como quando ela precisava também de grupos de pessoas para ir nas reuniões, nos comícios a gente se dispunha, trazia o ônibus e nós íamos.

197 Em entrevista para o Programa Roda Viva, exibido pela TV Cultura em 24/09/2007. Grifo nosso. 
E nos informa também de como a Rua de Lazer funcionava:

O kit é saco de estopa, jogos, rede, bolas de vários tipos e tamanhos, são todos os materiais para montar a Rua de Lazer. Os cones... a Prefeitura aciona a CET, fecha a rua, tem até uma placa aqui na rua, da Rua de Lazer, a gente tem essa placa oficialmente. Então a gente só soube da Rua de Lazer porque essa assessora veio falar pra gente que a gente tinha esse direito. Daí então a gente foi, o Ricardo foi fez o abaixo-assinado, eu entrei nesse projeto já em andamento. As idéias eram maravilhosas. A gente tinha os encontros, a gente conseguiu mobilizar adolescentes que se engajaram completamente, se entregaram, a gente tinha várias coisas. Tinha também o pessoal que vinha fazer o som, ainda que não fosse monitorado, porque o som era absurdamente alto e incomodava, e que não era direcionado para criança, eles se dispunham a trazer o equipamento. Então era maravilhoso e eram todos da comunidade. (...) Era maravilhoso também porque eu me sentia importante, me sentia participando de alguma coisa que beneficiava a mim e as crianças, enfim da alegria, a privacidade de ter a rua fechada pra nós. A gente fazia primeiro numa rua, depois na outra rua, a gente ia mesclando. Só que acabou œentralizando aqui na rua do meio porque era mais divertido, porque o Ricardo mora aqui e porque facilitava o transporte. (...)

A respeito do financiamento da Rua de Lazer pelo tráfico de drogas:

(...) nas Ruas de lazer que nós tivemos aqui, nós tivemos inclusive o financiamento do tráfico, por exemplo. Foi proposto pra gente colocar uma faixa que indivíduo tal estava ajudando. Quer dizer isso vai contra os meus princípios, ao mesmo tempo como é que você vai negar ajuda financeira? Não tem como, isso é assim uma coisa complicada. E na verdade não é isso que tem que impedir.

Sobre o fim da Rua de Lazer:

Então foi um processo maravilhoso, os dois anos que a gente realizou a Rua de Lazer. El acabou por falta de engajamento, de comprometimento dos envolvidos e também porque as demais pessoas não queriam contribuir, ora a mãe, ora outra pessoa. E na verdade, o que nós sentíamos? Nós sentíamos uma falta de assessoria. Oha, para se fazer alguma coisa você tem que saber como, a gente nunca soube como fazer. Né? Ees dão o kit e se vira, então essa pessoa envolvida com a política que a gente teve, às vezes ela podia, às vezes ela não podia. (...) $\mathrm{E}$ depois que acabou o kit não foi devolvido, ele foi "pulverizado".

A reflexão possível a partir do depoimento de Roberta permite-nos inferir o quanto é complicado e difícil o exercício da cidadania, pois o conhecimento do Projeto só chegou ao Conjunto pelos meandros dos interesses políticos de um vereador e sua assessora. A partir do conhecimento do Projeto e das reais possibilidades de ele acontecer beneficiando as crianças e os jovens do Conjunto Habitacional, essa cidadania é então barganhada: a Rua de Lazer em 
troca de grupos de pessoas para participar de reuniões e comícios. Se assim não tivesse sido a Rua de Lazer e tudo o que ela propiciou em termos de sociabilidade, integração, comprometimento, diversão não teria acontecido, ainda que conforme nos informa Roberta "qualquer comunidade, qualquer bairro possa solicitar a Rua de Lazer, todos tem direito". Mas o direito não é exercido de forma imparcial, ao contrário, nesse caso o direito foi exercido, cooptado pelo financiamento do tráfico e pela assessoria barganhada.

O fim da Rua de Lazer ocorre com a falta dos mesmos elementos que contribuíram para o seu sucesso: comprometimento, integração, engajamento, mobilização, convívio.

Lançamos um questionamento: não terá sido o financiamento do Projeto pelo tráfico também uma mola propulsora para o seu fim? Ainda que não tenhamos elementos suficientes para essa comprovação, é uma hipótese, pois muitos moradores, mormente as mães moradoras do empreendimento sabedoras da existência do tráfico de drogas e de quem são seus promotores, não são coniventes com sua prática, inclusive porque são as responsáveis pela educação das crianças e adolescentes (principal público alvo da Rua de Lazer).

As festas (aniversários, batizados, casamentos, formaturas) são essenciais para a vida cotidiana, e constituem também um modo de usufruir lazer senão para aqueles que passam pelos rituais, certamente para os convidados a partilharem do cerimonial de comemoração. De acordo com Roberto DaMatta (1991), nesses rituais - individualizados (aniversários, funerais) ou relacionais (batizados, casamentos) ocorre o deslocamento das atividades cotidianas de seus espaços e tempos normais. (p.46) Os espaços são reorientados, refuncionalizados, decorados; 0 tempo vivido e transcorrido de outra forma, e as atenções são também redirecionadas.

Mas, se o encontro, a sociabilidade, a festa estão sempre presentes no território cotidiano, tambémé necessário considerar os "desencontros".

Se as mortes naturais dizem respeito à debilidade da saúde dos moradores, sobretudo dos anciãos, as mortes induzidas ocorrem em virtude da violência urbana, cujas principais vítimas, há muito já se sabe, são os jovens do sexo masculino. № ano de 2007, dois casos exemplificam essa afirmação.

Ao assaltar com outros dois colegas uma empresa transportadora da área industrial do Jaguaré, um jovem de 20 anos morador do Conjunto Habitacional Parque Continental, fora surpreendido pela polícia no momento de sua fuga. Foi morto com quatro tiros ${ }^{198}$. Outro caso, não resultou em morte, mas na prisão de um jovem e sua esposa. Ex-funcionário de um cinema

198 Foi também homenageado pelos colegas no I Festival de Futebol do Mutirão realizado em outubro p.p. Outro jovem morador do Conjunto, morto por uma enfermidade na estrutura óssea dos membros inferiores também foi homenageado no referido Festival. Este último deixou grávida a namorada, que por sua vez batizou com o feminino do nome do pai a filha, também como forma de homenagem. 
que funciona dentro de um shopping center arquitetou um assalto aos cofres do cinema. Afim de não levantar suspeitas, foi com a esposa assistir à última sessão de uma produção hollywoodiana. A garota deveria permanecer na sala de projeção, enquanto o jovem efetuava o assalto, no entanto ele foi surpreendido por um segurança, que o atingiu com um tiro na mão. Ee revidou com outro tiro que matou o segurança. Imediatamente ele voltou à sala de projeção para encontrar a esposa e então sair do shopping com a quantia de $R \$ 15$ mil em uma mochila. Contudo, ao sair do estacionamento fora surpreendido dessa vez por um policial, que desconfiando dos sinais de agitação e o suor nos rostos dos jovens, numa noite fria do inverno paulistano, solicitou que levassem às mãos à cabeça quando percebeu os sinais de sangue em suas mãos e punhos. Os dois jovens foram detidos e ainda permanecem O caso repercutiu em toda mídia e também na área do Conjunto. Para os "colegas" a ação foi considerada estúpida, uma vez que há entre eles códigos de conduta que não devem ser descumpridos. Dentre os motivos considerados absurdos, um deles foi o jovem ter levado a esposa para participar, ainda que como coadjuvante da ação (para eles a família deve sempre ser protegida e nunca exposta ao perigo como nesse caso). Outra causa para a reprovação do assalto, foi o fato de o jovem ter estacionado seu veículo no estacionamento do shopping (o que no entendimento deles dificultou e não facilitou a fuga como era previsto), outro motivo tido como imperdoável foi o garoto não ter contado com a colaboração de qualquer outro "parceiro" para a empreitada, desse modo, não precisaria dividir o dinheiro que conseguisse com o assalto. Esse último motivo incorreu no não compadecimento dos "colegas" para as "correrias" necessárias quando alguém é detido: dinheiro, advogado, contatos etc.

Interpelado pela mídia sobre as razões de sua atitude, o garoto respondeu que necessitava quitar a dívida obtida para adquirir um automóvel Corsa Sedan Chevrolet (veículo inclusive usado para 0 assalto).

Esses dois acontecimentos são apenas exemplos que nos remetem a outros, ocorridos com outros requintes de astúcia (ou falta dela), em que as justificativas para os fatos são quase sempre a obtenção do que não possuem de maneira menos custosa que o trabalho de meses, anos à fio. Não raro, os jovens envolvidos em delitos (de maior ou menor gravidade) são oriundos de famílias, em que os membros sempre trabalharam, todavia, esses mesmos jovens não vêem na mesma proporção os frutos do trabalho no seio da família199: o automóvel da

199 Há na área do Conjunto outros casos de moradores que têm um membro da família, sempre, um jovem do sexo masculino detido nos inúmeros presídios espalhados pelo interior do Estado de São Paulo. Muitos quando presos foram imediatamente para as cidades do interior, outros cumprindo longas penas foram transferidos da Casa de Detenção do Carandiru (demolida em 2001), em virtude da política da Secretaria de Segurança Pública sob a égide de Mário Covas (à época a frente do executivo paulista). Para as mães, esposas, e companheiras está no rol de 
família (quando há) é sempre velho, o aluguel de minúsculas casas sempre fez parte do orçamento familiar e a favela ainda é uma possibilidade. Por estarem no lugar "certo", foram alvo de políticas públicas de provisão de habitação. Mas o modo de vida nem por isso foi completamente alterado. Se para suas famílias, é como nos diz José de Souza Martins "improvável sentir-se excluído quando é possível comprar o aparelho de TV ou a bicicleta" ${ }^{200,}$ para esses jovens há algo mais a entender no jogo inescrupuloso e perverso do capitalismo periférico. O que tentam é subverter as regras do jogo, ainda que suas armas e estratégias sejam mais frágeis, e talvez Ihes custe a liberdade (até onde se pode ser realmente livre) ou a vida. O certo é que estão dispostos a pagar, e pagam o preço. Odete Seabra (1996), revisando a insurreição do uso na obra lefebvriana reflete: "a criança no limite, continua sendo a expressão da espontaneidade para o viver; já os jovens, porque com os sentidos em plena explosão, estão em condições de desconfiarem, e desconfiam da usurpação de sentido!' (p.78).

Num mundo cada vez mais violento, em que impera toda sorte de violência, em todas as direções, a violência doméstica (porque no âmbito da vida privada) comparece. Teoricamente, nesse âmbito esperar-se-ia que o ambiente fosse o da tranqülidade, da acolhida, da compreensão, do cuidado, entretanto, isso não se cumpre na prática. A violência doméstica encontra expressão aqui em surras, agressões, greve de silêncio, quebradeiras, discussões, brigas, desavenças. Os agredidos, sempre mulheres e filhos ao pronunciarem-se sobre o assunto, elencam de maneira sucinta as razões para a violência praticada: adultério, alcoolismo, divergências quanto à educação dos filhos, desemprego, dívidas. Relações familiares regidas por uma sociedade contemporânea sob o signo da incerteza, da quebra de garantias e da insegurança. Condições sem as quais a autoconfiança, o controle e o discernimento do que é ou não nocivo às pessoas, de um modo geral, comprometem a capacidade de pensar e agir racionalmente. Daí a descarga por meio da violência.

Damiani (2005) relacionando a inserção produtiva com exclusões periódicas e exploração extensiva da força de trabalho reflete:

Disso à nova pobreza, que não vem estritamente da exploração do trabalho, mas da exclusão na produção, são os desempregados permanentes: vai-se do desemprego temporário e dramático ao permanente. Com isso há circulação de uma massa de dinheiro irrisória entre os pobres, dinheiro na forma de meios de circulação, e os

suas obrigações (além de uma infinidade de outras) a visita aos Domingos. Em virtude da distância das unidades prisionais, a saída acontece na noite do Sábado quando passam horas viajando em ônibus clandestinos. Sobre o movimento contra a instalação de presídios na região oeste do Estado de São Paulo ver Castilho, José Roberto Fernandes. Presídios e preconceitos. Boletim do Centro de Estudos da Procuradoria Geral do Estado, mai/jun 2001, p. 212-213.

200 A economia moral do décimo terceiro salário. O Estado de São Paulo, 04/12/2005. 
termos dessa circulação definem os limites da morte - inclusive, precoce, a dos jovens - e da sobrevivência crassa. Trata-se da negatividade absoluta do trabalho. Nas metrópoles, a negatividade do trabalho, o processo do que se define como acumulação primitiva, fundante do capitalismo, mas presente hoje, agora e aqui consiste nessas situações, vividas, em geral concomitantemente: as pessoas estão perdendo tudo - o emprego, especialmente o industrial; o espaço da moradia, são itinerantes dentro da cidade; a vida, com a violência - e estão inseridas perversamente no mundo do espetáculo, que lhes retira a identidade. Com o que ficam? Com a negatividade absoluta do moderno sistema produtor de mercadorias: com a miséria absoluta e a violência. (p.41)

A citação acima parece um "retrato" de nosso território cotidiano, onde uma das condições impostas aos jovens para inserir-se no sistema é a probabilidade da morte precoce. Entre pagar esse preço e viver a penumbra do não consumo, sabemos de suas opções. Estes ainda que desconfiados da armadilha, não possuem astúcia necessária para livrar-se dela $\mathrm{A}$ comparação entre os rendimentos lícitos ou não dos jovens e o rendimento de seus pais (trabalhadores desde tempos imemoriais) também contribui para subsidiar a opção por outros caminhos 201 .

\subsection{Tempo cotidiano - não linear e agora.}

Na perspectiva da teoria helleriana, o tempo cotidiano assim como o espaço cotidiano é também antropocêntrico. Assim como o espaço cotidiano se refere ao aqui do homem particular, o tempo se refere ao seu agora. O sistema de referência do tempo cotidiano é o presente. $E$ isto não somente sucede na vida cotidiana, mas também em outras objetivações genéricas.

As categorias das dimensões temporais na vida cotidiana que Agnes Heller aponta como importantes são: irreversibilidade, limite, medida do tempo, ritmo, momento e tempo vivido. A autora adverte que tais categorias foram extraídas da obra Crítica da vida cotidiana de Henri Lefebvre.

Irreversibilidade - A irreversibilidade enquanto conceito não aparece no pensamento cotidiano, mas o fato da irreversibilidade é parte orgânica de nossa consciência temporal cotidiana. Basta pensar no freqüente lamento pelas ocasiões perdidas, que não se aproveitaram, ou nas também freqüentes reflexões cotidianas segundo as quais "as coisas passadas já não voltarão", "o que está feito, feito está e não há remédio". (p.385)

${ }^{201}$ Como certa vez me disse um aluno em sala de aula: "Oque a senhora ganha em um mês eu consigo emuma correria sóf'. 
Essa categoria nos remete mesmo ao imediatismo da vida cotidiana, o anseio do planejamento para agora mesmo, para hoje, para dali a poucas horas, a preocupação para e com o presente como bem assinala Heller.

O limite (a morte, a geração) - A não resignação à irreversibilidade por parte dos homens é um modo de reagir ao fato irrevogável da finitude da vida, sua limitação. O saber relativo ao fim da vida, a morte (a nossa e a de outros), penetra todo o campo de ação da atuação e do pensar cotidianos. ${ }^{202}$ Se a única certeza que temos é a certeza da morte (nosso limite), pois a morte é tão certa, quanto irreversível, diante disso o que importa mesmo é o tempo presente, aquilo que podemos agora e não daqui a alguns anos, daqui a uma década. O dito popular vem nos dizer: "O futuro a Deus pertence", assim qualquer tentativa de projetar para além de agora, mesmo nossos passos, é vã.

Para a autora existem três tipos de atitudes diante da morte: a) Insensibilidade (são insensíveis aqueles que ainda sentem a morte como um fato natural, e por isso não se ocupam dela) b) Os temedores da morte (As pessoas desse tipo não são insensíveis, compreendem sua própria unicidade e a dos outros e são caracterizadas por dois tipos; o primeiro que não resignado pela morte se rebela e pergunta porque deve morrer; e o segundo tipo é aquele resignado que pode chegar inclusive ao desejo entusiasta da morte) c) Os aceitadores da morte (que sentem a morte) sobretudo a própria como algo natural, mas somente a morte natural, enquanto se rebela contra todo gênero de morte provocada pela mão do homem (op.cit, 387). Comumente, para esse terceiro grupo de indivíduos, a explicação da morte tem um sentido mítico-religioso e somente um Deus, uma força maior, tem o poder de "tirar" a vida dos homens.

A medida e a divisão do tempo - A divisão natural do tempo é certamente mais imprecisa que a do espaço, mas também utilizável em mais direções e com maior elasticidade. O dia e o ano são divisões "naturais" do tempo, mediante as quais se pode medir com suficiente exatidão, tanto o tempo como o espaço. Ainda hoje, depois de haver acordado a divisão do espaço, na vida cotidiana comunicamos as distâncias com definições temporais.(op.cit,p.389).

Queremos nesse momento, chamar atenção para essa consideração de Agnes Heller, isto porque, se as medidas de distâncias: centímetro, metro, quilômetros; do espaço são fundamentalmente importantes para o planejamento de cidades (obras de transporte coletivo, infra-estrutura viária, distribuição dos meios de consumo coletivo, etc), a vida cotidiana está impregnada pelo discurso que comunica as distâncias com definições temporais. "Não dizemos

202 Op. cit., 386. Grifos da autora. 
que até a estação há dois quilômetros, mas que a pé dista meia hora e de bonde vinte minutos" (op.cit., 389). E isso está com toda força na vida cotidiana. Atentamos ainda para o fato de que somente é possível comunicar distâncias espaciais a partir de definições temporais se detemos algum conhecimento desse espaço. Ainda que esse conhecimento não seja objetivo (pois para saber se estamos distantes do supermercado cinco quilômetros, devemos dominar a linguagem matemática e fazer mentalmente a conversão que transforma centímetros em metros e estes em quilômetros). O conhecimento subjetivo do espaço atribui outras capacidades aos indivíduos e desenvolvemos aquilo que podemos chamar de "reconhecimento". Imaginemos que a distância espacial entre a casa e o supermercado seja a mesma entre a casa e o hospital, daí o raciocínio que estamos desenvolvendo permite compreender que entre a casa e o supermercado e entre a casa e o hospital a distância espacial é de cinco quilômetros, no entanto, o homem cotidiano reconhece que supermercado e hospital estão igualmente distantes de sua casa porque o tempo que percorre para chegar a ambos é o mesmo, suponhamos 30 minutos, e não porque ele domine, saiba exatamente o que são ou que representa espacialmente cinco quilômetros. Importante também assinalar que nesse caso, o meio que dispõe para chegar até supermercado e hospital implicará diferença substantiva de tempo, mas nunca de espaço. Ou seja, a pé duas horas, de ônibus 30 minutos, de carro 15 minutos, de motocicleta tanto mais rápido. E a distância espacial percorrida será sempre a mesma: cinco quilômetros. ${ }^{203}$

A esse respeito Agnes Heller conclui "Quanto mais coisas devem ser feitas a cada dia e quanto mais rapidamente (por exigências internas e externas), tanto mais é necessário aprender a distribuir bemo tempo". (idem)

Oritmo do tempo - O tempo não "caminha" nem veloz nem lento: todo fato é igualmente irreversível. Pelo contrário, o ritmo do tempo muda notavelmente segundo os períodos históricos. A aceleração do ritmo do tempo é - ao menos desde a aparição do capitalismo, uma tendência geral da história. 204

A mudança do ritmo da história tem sempre efeitos sobre a vida cotidiana, mas não sobre a de cada particular, nem toca com a mesma intensidade cada aspecto seu.

${ }^{203}$ Gillberto Gil, compositor de Parabolicamará, incitando uma volta ao mundo nos dá a idéia da evolução dos meios de transporte. Para tal empreitada "de jangada leva uma eternidade, de saveiro leva uma encarnação, de avião o tempo de uma saudade". O que incita também a elasticidade do tempo.

204 Novamente recorremos à canção de Gillberto Gil. A idéia principal contida na letra é a diminuição das distâncias que começou com as grandes navegações, procedida das Revoluções Industriais e até chegar aos atuais meios de telecomunicações, transportes, etc. A ausência de limites para o tempo, ou de acordo com o pensamento helleriano o aumento do ritmo do tempo está expresso nos versos "Esse tempo não tem rédea, vem nas asas do vento". 
O ritmo de vida regulado e o descanso não são sinônimos de tensão e relaxamento205. Estas duas categorias se referem à obrigatoriedade do trabalho alienado e ao prazer de estar liberado dele. Para Heller, o descanso sob a forma de relaxamento é a contrapartida do trabalho alienado e constitui também um fenômeno de alienação. Talvez seu pensamento tenha sido o de empreender a possibilidade de tensão nos momentos de prazer e o seu contrário, o relaxamento no trabalho alienado. Em relação ao primeiro par dialético (tensão X prazer), basta pensar nos momentos de férias ansiosamente esperados por muitas pessoas. Também e inclusive nesses períodos, a tensão se faz presente. Oque dizer das filas intermináveis de terminais rodoviários e aeroportos, o tráfego intenso nas rodovias, a lotação de campings, hotéis, e pousadas, a inflação das diárias das casas de veraneio, e uma infinidade de pormenores que fazem do período de férias (a priori estabelecido como período de descanso, lazer, prazer) um período de máxima tensão? No que respeita ao par (relaxamento $X$ trabalho alienado) se tal relação é possível, talvez seja a maior prova de que o trabalho é alienado. Uma condição para o trabalho alienado é justamente a não desconfiança da alienação, conseguida quem sabe através do relaxamento.

O momento - O que é calculado como atraso em um lugar de trabalho, não o é em um encontro com os amigos. No trabalho, um atraso, seja ele de cinco ou 30 minutos, não se tolera, não faz parte do protocolo e, quando ocorre quase nunca vem acompanhado de compreensão, uma vez que a execução das tarefas no menor prazo possível é que é o estabelecido. Num encontro com os amigos, todo e qualquer atraso é tolerado, pois o que importa é que tal amigo, tal pessoa venha, pois após sua chegada o entretenimento, a alegria, o prazer da companhia são certos.

O tempo vivido - Todas as categorias precedentes, ainda que antropomórficas, são sempre objetivas, o tempo vivido é não somente antropomórfico, mas também subjetivo. A experiência interior temporal da pessoa particular não é mensurável de nenhum modo, ou melhor, não se pode expressar (descrever, captar) com a quantidade de tempo transcorrida. As experiências temporais interiores não tem nenhuma correlação com o tempo efetivamente transcorrido, com a quantidade de tempo medido com base em uma convenção social. "Se sou torturado para que confesse, cinco minutos pode parecer uma eternidade; pelo contrário, as horas felizes transcorrem como minutos. Eo mesmo vale para a experiência interior da ausência

205 Gritos da autora. 
de acontecimentos" ${ }^{206}$. (p.393)

Na experiência interior temporal, tem uma particular função a fantasia, a memória e a imaginação. O tempo da memória é a mais subjetiva das experiências interiores temporais. $O$ que eu revivo, é irreversível, a lembrança é simplesmente um momento desta irreversibilidade, e objetivamente não é mais nada. ${ }^{207}$ (idem)

O tempo vivido é outro que não o do relógio, medidor "oficial" do tempo. Este é pautado nas experiências mais íntimas e mais diferentes possíveis do tempo objetivo, ainda que o tempo vivido ocorra no tempo objetivo, mas a percepção de um e outro é ímpar.

O tempo vivido é, portanto, subjetivo porque é meu tempo, cada pessoa tem um tempo vivido distinto. É o tempo que se escolhe viver, é o período da vida, que escolhemos com quem estar, fazendo o que queremos ou que imaginamos querer fazer. É enfim, o tempo da experiência verdadeiramente compartilhada.

Heller acredita que os contatos sociais influenciam no tempo vivido dos sujeitos particulares.

Quanto mais numerosos são os fatos importantes, quanto mais ricos são de conteúdo os contatos humanos (relações), quanto mais iniciativa individual, ação autônoma, reflexão, é requerida aos homens pelo mundo, tanto mais "denso" será o mundo interior dos particulares. (...) Mais tempo viverão os particulares no curso do mesmo fragmento do tempo. (p.392)

Daí a importância da "saída da cotidianidade" que permitirá ao homem ordinário mais iniciativa individual, ação autônoma, nos termos de Henri Lefebvre, uma revolução cultural permanente.

\subsection{Convivência no Conjunto.}

Em tempo de finalizar essa pesquisa, algumas apreciações são ainda pertinentes ${ }^{208}$. Negligenciá-las seria a um só tempo, desperdiçar a observação atenta e as possibilidades de análise que ela revela, e também, descuidar de um aspecto agregador das dimensões da vida cotidiana verificadas por nós. Nesse sentido, o conjunto habitacional, na acepção literal do termo nos remete a inúmeras habitações unidas, conjugadas, próximas, contíguas e que por essas razões, demandam difíceis consensos por seus moradores. A vida em condomínio é, portanto, (e

206 Grifos da autora. Isso nos remete à corriqueira expressão quando da lembrança de outrora "Que tempo bom, que não volta mais" e a ciência de quem o profere de que a lembrança subjetivamente é memória, objetivamente não é mais nada.

207 Grifos da autora.

208 Esse momento refere-se exclusivamente a apreciações sobre os edifícios do Conjunto Habitacional Parque Continental. Considerações sobre as casas autoconstruídas serão feitas a seguir. 
tanto mais em conjuntos habitacionais produzidos para a população de menor renda) um microcosmo de toda a problemática social, que tem expressão nas diferenças, costumes, tensões e conflitos vivenciados pelas pessoas. Se em condomínios destinados à classe média, empresas administradoras fazem o intermédio no trato de questões que vão desde o uso da água, até a colocação da grama no jardim, em condomínios populares espera-se dos moradores a autogestão dos usos, e dos conflitos decorrentes destes.

A convivência no Conjunto Habitacional Parque Continental é tão conflituosa como o é para qualquer outro conjunto habitacional similar, ideológica e fisicamente. Pois, a apropriação do que é seu e, paralelamente, é do outro, é tão difícil de ser concebida pelos moradores como é difícil também de ser vivida, uma vez que a concepção da convivência harmoniosa em conjuntos habitacionais pairou sempre na cabeça dos idealizadores de políticas dessa natureza. Quando experiências malogradas ganharam evidência (como no caso das centenas de edifícios da COHAB na porção leste do município - com destaque para Itaquera) ${ }^{209}$, os planejadores e gestores de experiências posteriores atentaram para não "errar" novamente. Conceberam então, não novos edifícios do "padrão COHAB", mas simulacros seus, parecidos pela falta de privacidade, pelo espaço diminuto, pelas relações de vizinhança tão confusas, pela negação do espaço habitado por alguns moradores, pela identificação por tantos outros, pela falta de espaço para as crianças, pela falta de lazer.

Mas, o que é parecido é dialeticamente também diferente. Se os moradores das grandes "COHABs" implementaram diversos equipamentos de consumo coletivo com ou semo auxílio do poder público municipal, no sentido de dar à vida dos conjuntos características mais parecidas com a vida na "cidade ideal", visto que à época da implantação desses conjuntos, cidade não havia nos confins da zona leste, pois o projeto de urbe irrompeu com o envolvimento das milhares de pessoas para lá transferidas em virtude da magnitude do projeto210; o que se assiste no Conjunto Habitacional Parque Continental é uma dinâmica que caminha em sentido exatamente contrário, pois o Conjunto já está na "cidade ideal e real", inserido nela, ainda que limitado por muros. Desse modo, nada há em seu entorno, que tenha despertado em seus moradores a gana de lutar e/ou reivindicar melhorias. Na verdade, o entorno do Conjunto é provido de todos os meios e equipamentos de consumo coletivos necessários à vida de seus moradores, ou seja, a ausência de ausências intimida qualquer ação nesse sentido. ${ }^{211}$

209 Remeto o leitor a Damiani, Amélia L Cidade (des) ordenada. Concepção e cotidiano do conjunto Itaquera I. Tese de Doutorado. Departamento de Geografia. FFLCH/USP, São Paulo, 1991.

210 Idem.

${ }^{211}$ A intenção não é comparar os empreendimentos da COHAB implantados nas décadas de 1970 e 1980 com os Projetos Cingapura, são alguns apontamentos que nos permite reflexão. Por isso é preciso considerar que o 
Assim, se não há necessidade de lutar por questões coletivas "maiores", as "menores" esmorecem. O sentimento de propriedade (quando existe) diz respeito ao perímetro do apartamento somente, os espaços comuns são tão comuns que banais, administrá-los é como "chover no molhado". A pesquisa da situação e conservação do empreendimento, realizada pela equipe da SEHAB/HABI corrobora essa afirmação212. Foram avaliados cinco critérios, todos relativos somente ao bloco e não à célula habitacional: Avaliação dos Equipamentos de Segurança, Avaliação das Instalações de Gás, Avaliação das Instalações Hidráulicas, Avaliação das Instalaçães Elétricas, Avaliação da Conservação Geral do Bloco. De acordo com metodologia específica, foram atribuídas a cada um dos critérios notas de 0,00 a 10,00. $\mathrm{Na}$ somatória de pontos, os blocos com nota de 0,00 a 5,99 totalizaram 3 blocos, considerados em situação crítica. Os blocos com nota de 6,00 a 7,99 totalizaram 14 blocos, considerados em situação regular. $\mathrm{E}$ os blocos com nota 8,00 a 10,00 totalizaram 10 blocos, considerados em boa situação.

Quatro blocos do empreendimento contam com a atuação da Administradora de Condomínios Mega Sate, que responde pelos procedimentos para cobrança da taxa condominial, incluindo a divisão do valor mensal dos gastos comuns e o encaminhamento dos boletos para pagamento da referida taxa. Dos 4 blocos administrados pela empresa, apenas um foi avaliado em boa situação, dois avaliados como regular e um em condição crítica.

Nos outros blocos, as questões coletivas dizem respeito aos cálculos, recebimentos e pagamentos das contas, a limpeza do prédio (quando há), ao zelo pelas chaves comuns, a contratação onerosa ou não de algum senviço de manutenção213 que são realizadas pelo representante de bloco (síndico, tesoureiro, secretário). Ás vezes, há o acúmulo dessas funções por uma mesma pessoa.

Quanto a algum comportamento dissonante, não há como ou a quem recorrer. Assim são as queixas de alguns moradores, referindo-se direta ou indiretamente a conduta de outros: "Se tem alguém usando droga na minha janela ou no meu corredor o que eu vou fazer? A gente reclama, mas uma medida mais séria a gente sabe que não pode. É pior". "Mísica alta até tarde? Não tem o que fazer..." "Sujeira na minha porta? Se eu estiver incomodada eu que tenho que limpar". "Brigar por vaga no estacionamento? É um inferno! Com esse negócio das vagas

movimento social urbano atualmente em refluxo, foi importante protagonista das dinâmicas instauradas nas COHABs da zona leste nas referidas décadas.

212 Novamente não há possibilidade da reprodução total da avaliação de conservação do empreendimento no âmbito deste trabalho em virtude do detalhamento dos dados que se encontram às páginas 61 a 68 do referido relatório.

${ }^{213}$ O Relatório Analítico Empreendimento Parque Continental (2005) nos informa que 62,6\% dos moradores do empreendimento realizam reuniões com o representante de bloco e seus vizinhos. Parte dos entrevistados 32,7\% afirma que as reuniões são realizadas entre 2 e 6 meses. Mas há também percentuais que dão conta de que a última reunião foi realizada há mais de um ano e também há quem não saiba ou não se lembre das reuniões. 
ser de todo mundo do prédio, filho de fulana põe o carro aí, mas não mora aí, mas a mãe mora, então é como se a vaga fosse da mãe. Um infermo. Tem morador que não tem carro, daí outro morador que tem dois carros, usa duas vagas. Tá certo isso? (..) Pior o rapaz que comprou aí em cima, achou que estava comprando o apartamento e que tinha direito à vaga, ele demorou pra colocar o carro aí, quando foi colocar, a mulher aí embaixo fechou a vaga para o filho dela, ele foi reclamar, ficou duas horas brigando, reclamandb, não resolveu nada". "Ninguém quer saber de nada, um ou outro até propõe alguma coisa, mas é fraco, não consegue". "É por isso que eu te falo: Aqui dentro de minha casa eu adoro. Se eu pudesse pegar essa casa aqui e por lá, por na cabeça e por lá em outro qualquer lugar que eu conseguisse era bom demais (...) Agora o lugar, é o ambiente assim, as pessoas não respeitam a gente e isso faz a gente ficar com desgosto". ${ }^{214}$

A impotência de nada poder fazer no trato de assuntos que lhes dizem respeito está intimamente relacionada à coação a que estão expostos por uma minoria de moradores (expressão do poder paralelo de algumas áreas das periferias das grandes cidades de que todos temos notícias). Em mais de um relato ouvimos dos moradores casos de repressões sofridas por eles, ou relatos de terceiros. Não reproduziremos aqui detalhes desses casos a pedido dos moradores entrevistados, o fato é que "bater de frente" pode ter e tem várias implicações: humilhações, invasões, agressões, ameaças, expulsões do Conjunto.

Damiani (op. cit.) após tratar o espaço como estratégia política, traduzi-lo sob a forma de conjuntos habitacionais e desenvolver como se dava a apropriação do espaço nos conjuntos, conclui:

O espaço implica imediatamente o uso e o emprego do tempo, do tempo cotidiano. A vida cotidiana faz, então, essa mediação: da tentativa de consolidar e configurar o espaço, dominando-o, gerenciando seus usos, de alguma forma, congelando-o no tempo, à multiplicidade de escolhas, maneiras de viver, situações vividas. A fixidez do espaço se resolve na sua metamorfose constante: em significados, sentidos, consolidados e novos que vão adquirindo as ruas, as casas, os prédios, o conjunto, mesmo o bairro e a cidade. (p.319).

Considerando as aproximações cabíveis entre o estudo citado e nossa investigação, e depois de acompanhar durante todo o período da pesquisa os "desencontros" entre o concebido e o vivido do Conjunto, passamos a refletir: será o discurso da dominação oficial que legitima os conflitos do vivido, ou numa perspectiva contrária, são os conflitos do vivido que legitimam o discurso da dominação? Dito de outra forma: são as tentativas dos moradores de fazerem tal e

${ }^{214}$ Os fragmentos de depoimentos referem-se ao pensamento da coletividade, e não de uma única pessoa, quando perguntados sobre como é viver no Conjunto. 
qual sugere o concebido da forma que embate e conflita com a prática urbana de sempre: os estabelecimentos comerciais tão necessários à favela e tão mal quistos pela maioria dos moradores, o usufruto desmedido dos aparelhos eletroeletrônicos, o uso irracional da água, o dissenso da limpeza e asseio de espaços comuns, etc que têm de mudar por ter de responder a uma nova cultura, um novo conceito de habitar, e a adaptação necessária a esse novo conceito.

Novamente recorremos a Damiani (idem):

Ao reforçar a imagem do conjunto habitacional e ao remetêlo à de um espaço planejado, a realidade do homem comum se vê agregada a um nível de realidade mais elevado - o do Estado -, e de uma maneira imediata, na sua vida cotidiana. Essa relação metamorfosea-se na concepção de uma comunidade, fictícia, na qualidade de moradores de conjuntos habitacionais. Comunidade que paira fora de seus conflitos cotidianos, em nível de prédio, da vizinhança, etc. (p.308).

Mas, se assim é para os moradores originais do Conjunto, a relação não é a mesma para os novos moradores, pois idealizado para uma demanda específica: moradores favelizados (fundamentalmente aqueles emáreas de risco), faixa de renda de zero a três salários mínimos e outros critérios revisados por nós nos primeiros capítulos desse trabalho, o Conjunto Habitacional Parque Continental ganha diversidade, heterogeneidade com o tempo: alguns novos moradores egressos de moradia de aluguel, profissionais liberais, não possuem qualquer relação de tutela com o Estado, pois já adquiriram a moradia como mercadoria, sem inclusive intermédio do Estado na negociação, no tocante a valor, forma de pagamento, prazos, etc ${ }^{215}$.

${ }^{215}$ A proposta de comercialização da COHAB pelas unidades habitacionais já foi comunicada aos moradores. Mas alguns moradores quando alienam o imóvel negociam diretamente com o interessado sem a permissão da instituição. 

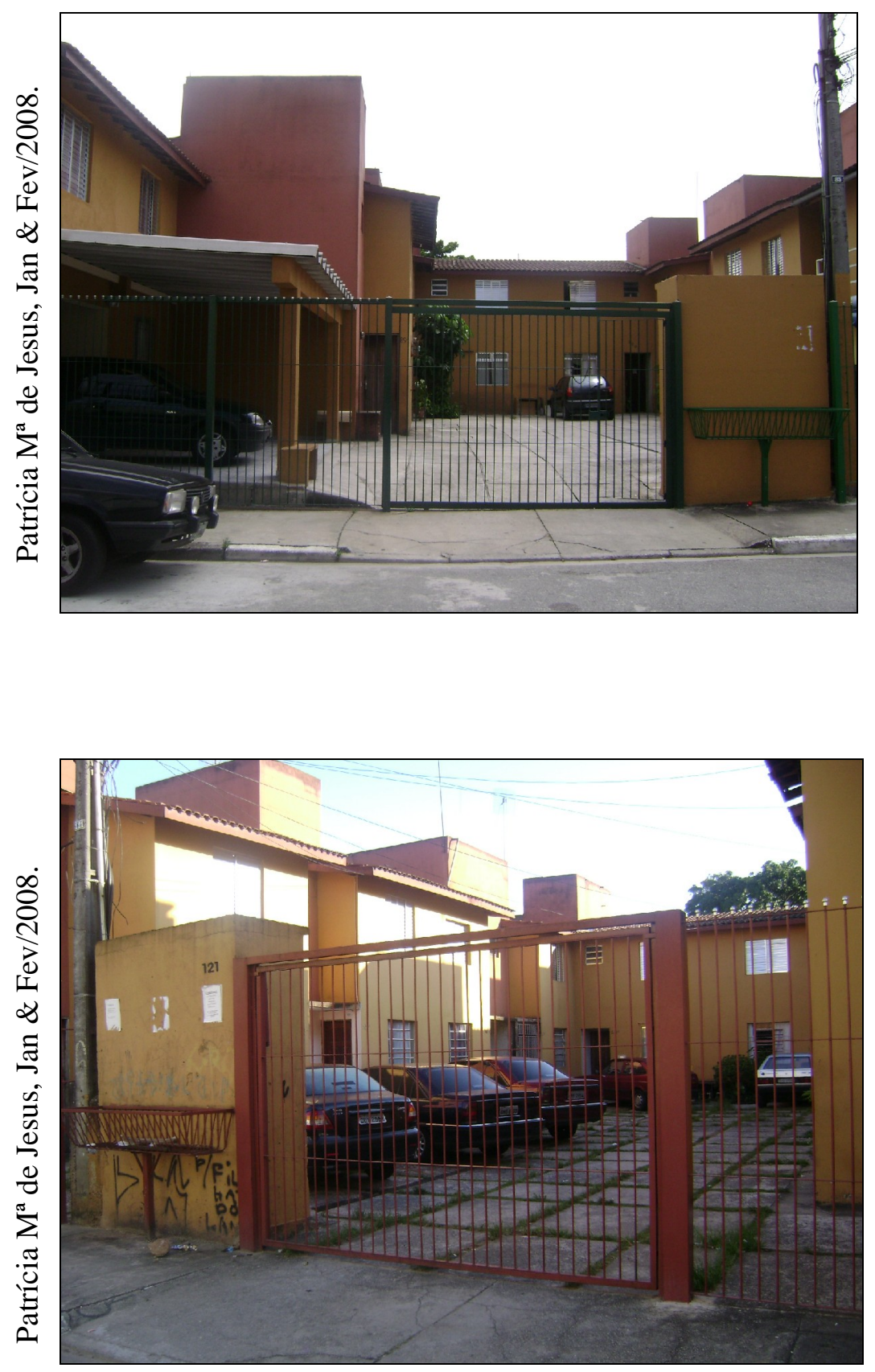

Fotos 07, 08: Vilas de casas no Mitirão. Conjuntos de 10 casas, cujos moradores aproveitando-se da especificidade destas parcelas do terreno (o grande recuo a partir da rua e a disposição das casas - uma de frente para outra) instituem dentro do Conjunto "pequenos condomínios", aos moldes dos condomínios destinados às classes médias, o que se confirma pela existência de um único portão para o conjunto das casas.

Em relação às casas autoconstruídas, um aspecto merece ser destacado, e o será em contraposição à análise feita acima acerca da dificuldade de convivência dos moradores dos edifícios Cingapura e Operações Interligadas. Para nós, está claro que os conflitos vividos nos prédios de apartamento dizem respeito à maneira como esse projeto foi implementado e como 
se deu o diálogo (ou a falta dele) dos planejadores do mesmo com a população envolvida. $O$ mesmo não se pode dizer do projeto do Mutirão, no entanto, no interior do projeto conflitos também afloraram entre os próprios moradores quando da construção das casas, o que contribuiu segundo seus depoimentos para um distanciamento tanto dos projetos coletivos, como das relações de vizinhança propriamente ditas.

No entanto, atualmente algumas dinâmicas em curso no Mutirão caminham na contramão das dificuldades de relacionamento e conflitos de toda sorte. O mais interessante para nós foi perceber o quanto o projeto arquitetônico do Mutirão vem determinando essas dinâmicas. Nas casas cuja frente está voltada diretamente para rua, não notamos indícios de relações mais estreitas de vizinhança, as palavras de dois moradores dessas casas confirmam: "não que os predinhos não sejam bons, eles são bons pra quem não tinha nada, mas a casa é muito melhor, muito melhor, pois nós aqui de casa que decidimos o que a gente quer, ou o que a gente não quer, não tem que dividir nada com ninguém, porque você vê, não dá certo, aqui a casa é totalmente individual" " Mas que papo furado essa conversa de pensar no coletivo, de um respeitar a opinião do outro, que mania! Eu não quero saber de nada não. Já me ralei todo pra construir isso aqui "coletivamente"216, agora já deu, agora eu mando na minha casa individualmente, você me entendeu? Ainda bem, graças a Deus" . Contudo, há na área quatro vilas, recuadas a partir do nível da rua, em cada uma delas existem 10 casas. No projeto original, não estava previsto o fechamento delas, mas de acordo com os moradores, há uns três anos começaram os fechamentos com os portões com o argumento inicial de aproveitar a área de fronte às casas para estacionamento e para as crianças brincarem. Não só isso tem se confirmado, como há outras tentativas a fim de estabelecer vínculos mais estreitos de sociabilidade: em uma dessas vilas, localizada à entrada do Conjunto, os moradores construíram inclusive uma praça, em que pudemos perceber em mais de uma ocasião a prática de jogar cartas, churrasco compartilhado com duas famílias, cantorias, etc. Constituem-se a nosso ver conjuntos dentro do Conjunto 217.

${ }^{216} \mathrm{Em}$ tom de ironia referindo-se à época de construção do Mutirão.

217 Outras considerações sobre as vilas do Conjunto à página 62 desse trabalho. 
Considerações finais.

Se como escreveu Wnston Churchill "primeiro construímos nossas casas, depois são elas que nos constroem" ${ }^{218}$, verificamos com essa investigação como os moradores do Conjunto Habitacional Parque Continental foram "construídos" pelas suas casas, após as terem construído material (no caso do mutirão) e imaterialmente (no caso dos edifícios de apartamento). Em outras palavras, inventariamos como o cotidiano como modo de vida transformou e redirecionou as atenções, ampliou e reduziu as habilidades da vida cotidiana, em suma, como o homem ordinário (designação de Mchel de Certeau para o homem cotidiano) modificou suas relaçães com o seu espaço de morar.

Nossa preocupação versou sobre a compreensão e apreensão da vida cotidiana dos moradores de um conjunto habitacional criado pelo Poder Público Municipal, resultado de três diferentes programas.

Uma de nossas hipóteses iniciais confirmada durante o processo de pesquisa, é que os programas habitacionais Produção de Unidades Habitacionais por Mutirão e Autogestão, as Operações Interligadas e o Programa de Verticalização e Urbanização de Favelas, distintos em suas diretrizes e concepções, refletiram nas diferentes formas de apropriação dos moradores do espaço privado da casa, mas também e inclusive, nos espaços públicos comuns: corredores, ruas, estacionamentos, etc... Assim, os indivíduos envolvidos com o processo de construção de suas casas no caso do Mutirão, envolveram-se também com o cuidado dos espaços públicos. As reformas internas e externas das casas autoconstruídas dão a medida da identidade do morador com sua moradia, fato impossível no caso dos prédios de apartamentos. As transferências de imóveis (vendas, locações, permutas) são menores na área do Mutirão e acreditamos que tal fato deva-se à apropriação efetiva com o espaço de morar e com a desproporção entre o número de casas e o número de apartamentos. Outra hipótese confirmada no curso dessa investigação, diz respeito à identidade do morador com o espaço habitado, aquilo que denominamos "território cotidiano". Es os motivos que contribuem para o processo identitário: no caso dos edifícios de apartamento lá estão também família e conhecidos, antigas referências, uma vez que em sua quase totalidade os moradores vieram dos mesmos lugares, e quando não são vizinhos diretos morando no mesmo andar, no mesmo prédio, a distância é somente aquela que separa uma e outra rua do Conjunto. Já nas casas autoconstruídas, a identidade com esse espaço deve-se fundamentalmente à construção propriamente dita da casa. Como apareceu no relato de uma

${ }^{218}$ Citado por Milton Santos em Pensando o espaço do homem, 2004. p.31. (Original de 1982). 
moradora, mas que expressa também outras opiniões: "aqui eu coloquei tijolo em cima de tijolo, foi muito difícil, então foi a realização de um sonho e por isso eu gosto tanto, é a minha casa". No entanto, é justamente essa apropriação que impede outros moradores descontentes, e insatisfeitos com o desmonte das idéias coletivas e com os conflitos vividos à época da construção do Mutirão, de mudarem dali: "eu queria ir embora, mas como eu vou vender isso aqui, que eu lutei tanto, que eu suei tanto, e tanto que eu já fiz por essa casa, mesmo depois de ela pronta, não tem preço, então mesmo insatisfeito eu continuo aqui". Diferentemente dos apartamentos, as casas possuem maior valor de uso que de troca, embora isso não impeça as possibilidades de alienações, pois, uma vez prontas, as habitações constituem-se em mercadoria. Por outro lado, com as alienações dos imóveis a intimidade com a rua ou com a totalidade do Conjunto tende a aumentar, pois as transações dificilmente ultrapassam as relações interpessoais dos moradores. Significa dizer que os apartamentos ou casas são vendidos na maioria dos casos para parentes, amigos ou pessoas próximas, contribuindo dessa forma para maior solidez às redes sociais. Ainda em relação à identidade com o espaço habitado, constatamos o espaço espećifico da rua como extensão do espaço doméstico, pois comportamentos e atividades que normalmente ocorrem no espaço privado da casa transbordam-na por falta de espaço e privacidade.

A apropriação do espaço específico da habitação ocorre nos limites da individualidade: assim os moradores exaltam "a casa boa num lugar ruim", a autoridade sobre as regras e ordem das moradias, a autonomia das mudanças, e alterações, ainda que essas últimas não sejam "autorizadas" pela Prefeitura Municipal. O vizinho aparece como problema, mas só o é, porque nesse caso se conhece o vizinho: suas referências, preferências, intenções, gostos, comportamentos. Não há problemas e conflitos com desconhecidos.

Quanto à apropriação dos outros espaços: corredores, estacionamentos, lixeiras, ruas, centro comunitário, bares, e pontos de comércio; ou seja, do empreendimento como um todo, para além das paredes da casa, ocorre de maneira paradoxal. Por um lado, a apropriação se dá em seu contrário: negando a própria apropriação. Daí a falta de cuidado, depredações, vandalismo, quebradeiras, sujidades. Por outro lado, submetidos à segregação, senão espacial (se considerada a localização do empreendimento), mas social (se considerados os rendimentos das famílias, inserção no mercado de trabalho e outras variáveis) vemos então a apropriação firmada e afirmada. Daí a proliferação de pontos comerciais, de senviços e de lazer criados por eles para eles. É necessário ressaltar, aliás, que a criação desses estabelecimentos não se trata de "empreendedorismo", só fazem sentido num contexto de desemprego estrutural para a população que não possui as qualificações exigidas pelo mercado de trabalho. Por outro lado, há 
também aqueles que se aproveitam da oportunidade, construindo uma garagem, um depósito, pois se houve um "pioneiro" nas construções, outros também querem fazêlo, para "ocupar o espaço". Destarte, a combinação desses elementos com os parcos rendimentos da população moradora do Conjunto e suas relações de sociabilidade estabelecem então a apropriação.

O que se verificou com toda potência é que a funcionalidade do habitat não é suficiente para regular toda a vida, pois ainda que morar em apartamentos ou casas propositalmente funcionais signifique organizar certos aspectos da vida de uma determinada maneira só, outros tantos aspectos do habitar encontram outras fendas para realizar-se: uma mesa de sinuca que serve de palco para bandas, um automóvel que funciona como bar, um hidrômetro que substitui o banco da praça. $\mathrm{A}$ (re) significação de coisas, objetos e lugares dá conteúdo à vida cotidiana, mesmo que esta esteja absorta em normas e condutas pretensamente homogêneas idealizadas pelos promotores do empreendimento e calcadas no modo burguês de apropriar-se do espaço. Foram exatamente esses ideais homogêneos e burgueses que frustraram a maioria das famílias que só queriam mudar de vida e esquecer a favela, pois os seus "resquícios", aquilo que sobrou dela, transbordou as paredes de madeira e zinco e seus interstícios e resiste, para o bem ou para o mal, às aspirações daqueles que queriam exorcizar o "espírito mal" dessa forma urbana. Isto porque, muitos moradores viram na mudança do barraco para o apartamento, e da favela para o Projeto Cingapura Parque Continental (desprovido de favelas no entorno imediato), uma clara oportunidade de "mudar de vida". No entanto, a favela resiste em forma, função e conteúdo: desde a proliferação em áreas coletivas do empreendimento de casas semelhantes às habitações da favela, até a recorrência de dinâmicas e acontecimentos comuns nesses espaços: crimes, violência, vandalismo, repressões, conivências. Dinâmicas inclusive contrárias aos discursos da "solidariedade entre os pobres"219. Assim, se para alguns isso não constitui problema, para a maioria é o que confere depreciação ao empreendimento, o que estimula o surgimento de um estigma, e o que frustra sobremaneira a grande maioria dos moradores desse Conjunto Habitacional. A fala de uma moradora resume esse sentimento: "As pessoas esqueceram que aqui não é favela, elas mudaram da favela, tinham que ter deixado a favela lá, e não trazer a favela junto. O difícil não é tirar você da favela, mas tirar a favela de você".

O desmonte do Estado e dos seus direitos sociais em curso no país desde a década neoliberal de 1990 encontram no Conjunto Habitacional suas expressões: situado em uma

\footnotetext{
${ }^{219}$ Para nós, a falta de mediação nestes espaços da polícia, Prefeitura Municipal, sindicância etc, resulta numa impotência que "retro-alimenta" esse processo, de maneira que os conflitos decorrentes dessas dinâmicas tomam proporções maiores se compararmos contextos urbanos em que elas também ocorrem, mas em que há algum tipo de intervenção.
} 
parcela do distrito do Jaguaré desprovido de favelas e Conjuntos Habitacionais similares no seu entorno imediato, nada há nesse território cotidiano (além do próprio Conjunto) que lembre a assistência social do Estado: nem creches comunitárias, nenhum projeto substancial municipal220, estadual ou federal para a demanda do Conjunto, nenhuma oficina cultural para os adolescentes, nenhum curso profissionalizante para os jovens. Nenhuma assistência religiosa, de organizações não governamentais, da filantropia privada, de agentes externos. Pode o leitor mais atento indagar se não há na área estudada uma autonomia que "dispense" as proclamadas assistências. Nem a autonomia da autogestão, nem a assistência pública ou privada. Como adverte Amélia Damiani (2005):

É necessário admitir a presença de uma mobilização popular, nas duas últimas décadas, que se apresenta deteriorada, em movimentos conformes as institucionalidades postas, em uma nova abordagem do clientelismo institucional quando o aparato de leis sugere desdobramentos até o ponto de atingir a vida cotidiana de modo heteronômico (p.9).

Eis o que há: conformismo incapaz de contestação.

Os jovens preocupados com seus arroubos percorrem o "melhor" e o "menor" caminho para obtenção do êxito: ansiosos pelo ensino superior e cobrados pelo mercado de trabalho, combinam parcos rendimentos com universidades privadas, outros "grávidos" precocemente, saem das casas dos pais para pagar aluguel nas imediações, ou encontram na favela uma real possibilidade e passam a engrossar (agora em outro contexto) a fila da demanda habitacional. Aos preocupados em obter automóveis e motocicletas para passear e ou trabalhar, restam duas opções: parcelar em um sem-número de vezes a compra com desconto em folha de pagamento (para aqueles com carteira assinada), ou ser açambarcado pela trama e o drama do mundo do crime.

Quanto aos adultos resta cuidar da casa, do apartamento, do seu "pedacinho", "da parte que lhes cabe nesse latifúndio", onde sem necessidade de consultas prévias é possível mandar e desmandar, prover os menores das necessidades básicas e esperar melhores dias. Eles virão!

Sem práxis, sem atividade criadora, vítimas passivas como denunciou Henri Lefebvre sobre a vida cotidiana. A revolução cultural permanente sugerida por esse autor de maneira alguma encontra subsídios para se realizar. Ao contrário, enredados nas tramas das ordens próximas, mais ainda das ordens distantes, o homem ordinário 221 , é capturado pelo sistema,

${ }^{220}$ Ainda em caráter experimental demos conta de um projeto de educação de jovens e adultos da prefeitura do município na área do Conjunto.

${ }^{221}$ Ao longo desse trabalho dialogamos com diversos autores interessados no sujeito do cotidiano e deparamo-nos com muitas terminologias para designá-lo (cf. referências bibliográficas). Homem lento para Milton Santos, homem 
substituindo uma alienação por outra. As (re)significações que empreendem aos seus conteúdos, e a sublevação possível das ordens postas e impostas, são insuficientes para a emancipação do homem, para sua autonomia, e exercício pleno de cidadania.

Toda a discussão pautou-se na identificação do cotidiano como modo de vida específico da contemporaneidade, locus da reprodução das relações sociais de produção. Relações reguladas pela mercadoria de produtos, mas também de tempo, espaço, símbolos, representações.

A tentativa foi revelar a vida cotidiana em toda sua complexidade e contradição: espontânea e programada, homogênea, mas também heterogênea, subversiva, tanto mais alienada, escancarada, oculta. Isso porque, antropocêntrica, como bem salientou Agnes Heller. Estudar o microcosmo de um Conjunto Habitacional não reduziu a análise à mesma escala, pois foi preciso considerar demandas estruturais, e superestruturais do modo capitalista de produção em sua periferia. E considerar fundamentalmente o cotidiano não como demanda pretérita, mas como processo no ápice de seu curso e no ápice também de sua crise.

De acordo com Henri Lefebvre "mostrando como as pessoas vivem, a crítica da vida cotidiana instala o ato de acusação contra as estratégias que conduzem a tal resultado" (1999 p.129). Contribuir nesse sentido, eis o nosso exercício.

simples para José de Souza Martins, homem ordinário para Michel de Certeau, homem cotidiano para Henri Lefebvre, e Agnes Heller embora faça a análise do mesmo homem o denomina simultaneamente como indivíduo humano genérico e individual particular. 
Referências Bibliográficas

ALMEIDA, Cecília Cardoso Teixeira de. Indivíduo e Cotidiano: A formação do habitat. Dissertação de Mestrado. Departamento de Geografia - FFLCH/USP.São Paulo, 1996.

ALMEIDA, Sheila Regina de. O lugar de morar: sua representação por moradoras de apartamento. Dissertação de Mestrado. Departamento de Psicologia Social - PUC/ SP. São Paulo, 1983.

ANTOGIOVANNI, Lídia Lúcia. Teritórios reticulados e os constrangimentos aos teritórios do cotidiano. In: Anais do X Encontro de Geógrafos da América Latina. Universidade de São Paulo. São Paulo, 2005. p. 1018 a 1030.

AJZENBERG, Armand. As classes sociais e suas formas modemas de luta. In: Revista GEOUSP - Espaço Tempo, São Paulo, no17. 2005. p.09 a 19.

BARCELOS, Jorge Alberto Soares. Territórios do cotidiano: introdução a uma abordagem teórica contemporânea. Ir. Territórios do cotidiano: uma introdução a novos olhares e experiências. MESQUITA, Zlá \& BRANDÃO, Carlos Rodrigues (orgs). Porto Alegre/Santa Cruz do Sul: Ed. Universidade/UFRGS/ Ed. Universidade de Santa Cruz do Sul/UNISC,1995.p.40-48.

BISILLIAT-GARDET, Jeanne. Mutirão - Utopia e necessidade. CNPq - ORSTOM. Sem data.

BONDUKl, Nabil. Arquitetura e habitação social em São Paulo 1989-1992. São Paulo: Instituto dos Arquitetos do Brasil e Fundação Bienal de São Paulo, 1993.

Habitação, mutirão e autogestão: a experiência da administração Luiza Erundina em São Paulo. In: Habitat: as práticas bem sucedidas em habitação, meioambiente e gestão urbana nas cidades brasileiras. BONDUKI, Nabil. (org).São Paulo: Studio Nobel, 1996.

Origens da habitação social no Brasil: arquitetura moderna, Lei do Inquilinato e difusão da casa própria. São Paulo: Estação Liberdade, 1998. 
CARLOS, Ana Fani A. O lugar no/do mundo. São Paulo: Hucitec,1996.

O espaço urbano. Novos escritos sobre a cidade. São Paulo: Contexto, 2004.

CASTILHO, José Roberto Fernandes. Presídios e preconceitos. Boletim do Centro de Estudos da Procuradoria Geral do Estado, mai/jun 2001, p. 212-213.

CERTEAU. Michel de. Teoria e Método no Estudo das Práticas Cotidianas. In: Cotidiano, Cultura Popular e Planejamento Urbano. São Paulo: FAU/USP, 1985.

A invenção do cotidiano: 1. Artes de fazer. Tradução: Ephraim F. Alves e Lúcia Endlich Orth. Petrópolis: Vozes, 1994.

. et all. A invenção do cotidiano: 2. Morar, cozinhar. Tradução: Ephraim F. Alves e Lúcia Endlich Orth. Petrópolis: Vozes, 1996.

DAMATTA, Roberto. Espaço: casa, rua e outro mundo: o caso do Brasil. In: A casa \& a rua. Espaço, cidadania, mulher e morte no Brasil. Rio de Janeiro: Editora Guanabara Koogan S.A, 1991.

DAMIANI, Amélia Luisa. Cidade (des)ordenada. Concepção e cotidiano do conjunto Itaquera I. Tese de Doutorado. Departamento de Geografia. FFLCH/USP, São Paulo,1991.

O lugar e a produção do cotidiano. Novos Caminhos da Geografia. São Paulo: Contexto, 1999 p.161-170.

A geografia e a produção do espaço da metrópole. Entre o público e o privado. In: Urbanização e Mundialização: Estudos sobre a metrópole. CARLOS, Ana Fani A \& CARRERAS, Carles.(orgs). São Paulo: Contexto, 2005. (Novas Abordagens. GEOUSP; v.4)

DEBORD, Guy. A sociedade do espetáculo. Comentários sobre a sociedade do espetáculo. Tradução: Estela dos Santos Abreu. Rio de Janeiro: Contraponto, 1997. 
ECO, Humberto. Viagem na irrealidade cotidiana. Editora Nova Fronteira: Rio de Janeiro, 1984. Tradução: Aurora Fornoni Bernardini \& Homero Freitas de Andrade.

ELIAS, Norbert \& SCOTSON, JOHN. Os estabelecidos e os outsiders. Sociologia das relações de poder a partir de uma pequena comunidade. Rio de Janeiro: Jorge Zahar Editor,2000.

FEUIPE, Joel P. Cingapura X Mutirão. Por dentro da polêmica. Anais: Encontro Nacional de Tecnologia do Ambiente Construído. Tecnologia e Qualidade na Habitação. Volume II. Novembro, 1993.

FEITRAN, Gabriel de Santis. Desvelar a política na periferia: Histórias de movimentos sociais em São Paulo. São Paulo: Associação Editorial Humanitas: Fapesp, 2005.

FORATO, Sylvia \& RIBEIRO, Wagner da Costa. Habitação em São Paulo e financiamento externo. In: Scripta Nova Revista Eectrônica de Geografia y Ciências Sociales. Universidad de Barcelona. Vol VII, no 146(097). Barcelona, 2003.

GOLDENSTEIN L, ROSSINI R.O bairro industrial do Jaguaré. In.Boletim Paulista de Geografia. n.. 47, maio de 1972, AGB Regional São Paulo.

GONÇALVES, Roberto.O déficit habitacional brasileiro: um mapeamento por unidades da federação e por níveis de renda familiar. Texto para discussão no 559 . IPEA: Rio de Janeiro, 1998.

HADDAD, Femanda de Macedo. Práticas e representações do lazer dos moradores da favela Goiti. Dissertação de Mestrado. Faculdade de Arquitetura e Urbanismo da Universidade de São Paulo. São Paulo,1999.

HAESBAERT, Rogério. O mito da desterritorialização: do "fim dos territórios" à multiterritorialidade, Rio de Janeiro: Bertrand Brasil, 2004.

- Concepções de território para entender a desterritorialização. In: Território Territórios. Programa de Pós - Graduação em Geografia - Universidade Federal Fluminense/AGB - Niterói, 2002. p.17-38. 
HEUER, Agnes. O cotidiano e a história. $4^{a}$ edição. São Paulo: Paz e Terra, 1992. Tradução: Carlos Nelson Coutinho \& Leandro Konder.

Sociologia de la vida cotidiana. $4^{a}$ edição. Barcelona: Ediciones Península,1994.

Traducción: J.f. Yvars \& E. Perez Nadal.

. Agnes Heller entrevistada por Francisco Ortega. Rio de Janeiro: EdUERJ,2002. (Coleção Pensamento Contemporâneo).

JESUS, Patrícia $M^{p}$ de. Produção do Espaço Urbano no Jardim Humberto Salvador, Presidente Prudente/SP: afastamento, exclusão ou segregação socioespacial? Monografia (Bacharelado em Geografia) - FCT/UNESP, Presidente Prudente, 2005.

KRAHENBUHL, Lair. Cingapura: o encontro de São Paulo com a cidadania. Bix Design Corporativo Editora: São Paulo, 1996.

LEFEBVRE, Henri. Estrutura social: a reprodução das relações sociais. In: Sociologia e sociedade (Leituras de introdução à Sociologia). FORACCH, Marialice Mencarini \& MARTINS, José de Souza (orgs).Rio de Janeiro: LTC - Livros Técnicos e Científicos, 1985 (10ª edição).

A vida cotidiana no mundo moderno. Tradução: Alcides João de Barros. São Paulo: Ática, 1991.

. A revolução urbana Tradução: Sérgio Martins. Belo Horizonte: Editora UFMG, 2004.

Henri. De lo rural a lo urbano. Tradução: Javier González-Pueyo. Barcelona, 1975, p.5-18, 139-145.

LIMONAD, Ester (org). Entre a Ordem Próxima e a Ordem Distante: contribuições a partir do pensamento de Henri Lefebvre. Niterói: UFF/CEGEL,2003. 
MANENTE, Fábio César M. A moradia popular chegou à Serra da Cantareira. Dissertação de Mestrado. Departamento de Geografia - FFLCH/USP.São Paulo, 2001.

MARQUES, Eduardo \& SARAIVA, Camila. As políticas de habitação social, a segregação e as desigualdades sociais na cidade. In:São Paulo. Segregação, pobreza e desigualdades sociais. MARQUES, Eduardo \& TORRES, Haroldo (orgs). São Paulo: SENAC, 2005.

MARTINS, José de Souza(org). Henri Lefebure e o retorno à dialética. São Paulo: Hucitec,1996. . A sociabilidade do homem simples. São Paulo: Hucitec,2000.

$\overline{04 / 12 / 2005}$

A economia moral do décimo terceiro salário. O Estado de São Paulo,

MESQUITA, Zlá. Cotidiano ou quotidiano? In: Territórios do cotidiano: uma introdução a novos olhares e experiências. MESQUITA, Zlá \& BRANDÃO, Carlos Rodrigues (orgs). Porto Alegre/Santa Cruz do Sul: Ed. Universidade/UFRGS/ Ed. Universidade de Santa Cruz do Sul/UNISC,1995.p.12-26.

MIAGUSKO, Edson. Experiência e pobreza nas bordas da cidade: o caso de um conjunto habitacional produzido por mutirão autogestionário. In: Anais do 31ํ- Encontro Anual da ANPOCS. Caxambu: Outubro,2007.

MODENA, Carla Cristina. No shopping da divisa. In: À margem do Ipiranga. MEDINA, Cremilda. (org). São Paulo: CJE/ECA/USP, 1991. p.163 -173.

PEREIRA, Priscila Maria Santiago. Intervenção habitacional em favelas no município de São Paulo através do Projeto Cingapura: o Conjunto Zaki Narchi. Dissertação de Mestrado. Escola Politécnica da Universidade de São Paulo. Departamento de Engenharia da Construção Civil. São Paulo,2001.

PETERSEN, Silvia Regina F. O cotidiano como objeto teórico ou o impasse entre ciência e senso comum no conhecimento da vida cotidiana. In: Territórios do cotidiano: uma introdução a novos olhares e experiências. MESQUITA, Zlá \& BRANDÃO, Carlos Rodrigues (orgs). Porto 
Alegre/Santa Cruz do Sul: Ed. Universidade/UFRGS/ Ed. Universidade de Santa Cruz do Sul/UNISC,1995.p.30-39.

Dilemas e desafios da historiografia brasileira: a temática da vida cotidiana. In: Territórios do cotidiano: uma introdução a novos olhares e experiências. MESQUITA, Zlá \& BRANDÃO, Carlos Rodrigues (orgs). Porto Alegre/Santa Cruz do Sul: Ed. Universidade/UFRGS/ Ed. Universidade de Santa Cruz do Sul/UNISC,1995.p.49-66.

POE. Edgar Allan. O diabo no campanário. In: Histórias Extraordinárias de Allan Poe. Tradução e Adaptação: Clarice Lispector.São Paulo: Ediouro, 2004.

RAFFESTIN, Claude. Por uma geografia do poder. Tradução: Maria Cecília França. São Paulo: Editora Ática, 1993.

ROCHA, Alexandre Souza da. Centralidade e periferia na grande São Paulo. Abordagem crítica sobre o morar na periferia da metrópole. Dissertação de Mestrado. Departamento de Geografia - FFLCH/USP.São Paulo, 2000.

RODRIGUES, Arlete Mbysés. Na procura do lugar o encontro da identidade. Um estudo do processo de ocupação de terras: Osasco. Tese de Doutorado. Departamento de Geografia FFLCH/USP. São Paulo, 1988.

, Moradia nas cidades brasileiras. São Paulo, Contexto,1988.

RODRIGUES, Soraia. Casa própria ou apropriada. Duas abordagens:Funaps Comunitário e Projeto Cingapura. Dissertação de Mestrado. Faculdade de Arquitetura e Urbanismo -USP. São Paulo, 2006.

SANTOS, Milton. Técnica, espaço, tempo. Globalização e Meio Técnico-científico Informacional. São Paulo: Editora Hucitec,1994.

. et all.O papel ativo da Geografia: um manifesto. Forianópolis: XII Encontro Nacional de Geógrafos,2000. 
Por uma outra globalização. Do pensamento único à consciência universal. $6^{0}$ ed. Rio de Janeiro: Record, 2001.

A natureza do espaço. Técnica e Tempo. Razão e Emoção. p.313 -330. São Paulo: Edusp,2002.

Território e Dinheiro. In: Território Territórios. Programa de Pós - Graduação em Geografia - Universidade Federal Fluminense/AGB - Niterói, 2002.p.09-15.

SÃO PAULO. Prefeitura Municipal. Relatório final da Comissão Parlamentar de Inquérito para apurar as Operações Interligadas (Leis $n^{0}$ 10.029/86 e $n^{0}$ 11.426/93) realizadas no município de São Paulo desde a promulgação da Lei no 10.029/86. São Paulo, 2002.

- Relatório Analítico. Empreendimento Parque Continental. Plano de Regularização, Recuperação de Créditos e Revitalização dos Empreendimentos do PROVER, PROCAV e GUARAPIRANGA. SEHAB/HABI, 2005.

Diagnóstico Integrado. Empreendimento Parque Continental. Plano de Regularização, Recuperação de Créditos e Revitalização dos Empreendimentos do PROVER, PROCAV e GUARAPIRANGA. SEHAB/HABI,2005.

SEABRA, Odette Carvalho de L Territórios do uso: Cotidiano e modo de vida. In: Revista CIDADES. Vol.1, ㄲo2 - Presidente Prudente: Grupo de Estudos Urbanos, 2004.

SILVA, Armando Corrêa. Ponto de vista - o pós-marxismo e o espaço cotidiano. In: Territórios do cotidiano: uma introdução a novos olhares e experiências. MESQUITA, Zlá \& BRANDÃO, Carlos Rodrigues (orgs). Porto Alegre/Santa Cruz do Sul: Ed. Universidade/UFRGS/ Ed. Universidade de Santa Cruz do Sul/UNISC,1995. p.27-29.

SILVA, Expedito Leandro. Forró no asfalto: Mercado e Identidade Sociocultural. São Paulo: FAPESP/Annablume, 2003. 
SILVA, Fávia Eaine. O Distrito Industrial Jaguaré pelo seu desvio: Urbanismo e Vida Cotidiana. Trabalho de Graduação Individual. Departamento de Geografia - FFLCHUSP. São Paulo: 1998.

. Favela, que negócio é este? Um estudo sobre o projeto de urbanização da favela do Jaguaré no contexto dos negócios urbanos e de sua reprodução crítica. Dissertação de Mestrado. Departamento de Geografia - FFLCH/USP. São Paulo: 2006.

SILVA, Luís Otávio. Parcerias público-privado no financiamento de investimentos urbanos: a experiência das Operações Interligadas no município de São Paulo. Publicação do Programa de Pós-Graduação Stricto Sensu em Arquitetura e Urbanismo Universidade São Judas Tadeu. São Paulo, 2006.

SILVA, Vanildo Luís. Cingapura: a espacialidade do programa habitacional do município de São Paulo na década de noventa do século XX. Dissertação de Mestrado. Departamento de Geografia - FFLCH/USP.São Paulo, 2003.

SOUZA, Gustavo de Oliveira C. Do projetado ao vivido, a construção do lugar. O meio ambiente na produção de conjuntos habitacionais. Tese de Doutorado. Departamento de Sociologia - IFCH/UNICAMP. Campinas, 1997.

VAINER, Carlos. Reflexões sobre o poder de mobilizar e imobilizar na contemporaneidade, In: PÓVOA NETO, Helion (org). Cruzando fronteiras disciplinares: um panorama dos estudos migratórios. Rio de Janeiro: Revan,2005.

VLARES, Henrique Dumont. A indústria em São Paulo. (Estudo para a sua localização). Centro Industrial Jaguaré.São Paulo, 1939. 